Rose Satiko Gitirana Hikiji

\title{
A música e o risco
}

\author{
uma etnografia da performance musical entre crianças \\ e jovens de baixa renda em São Paulo
}

Universidade De São Paulo

Faculdade de Filosofia Letras e Ciências Humanas

Departamento de Antropologia Social

Programa de Pós-graduação em Antropologia Social

orientação Profa. Dra. Sylvia Caiuby Novaes

Tese de Doutoramento - 2003 
Rose Satiko Gitirana Hikiji

\section{A música e o risco}

uma etnografia da performance musical entre crianças e jovens de baixa renda em São Paulo

orientação Profa. Dra. Sylvia Caiuby Novaes

Tese de Doutoramento - 2003 


\section{ABSTRACT}

THE MUSIC AND THE RISK

An ethnography of musical performance among poor children and young persons in São Paulo

The research is an anthropological approach of an institutional project of musical education for poor children and youth in São Paulo (Projeto Guri), some of them under custody of Febem. The ethnography looks toward the different aspects of music making, like musical teaching, learning and performing, and tries to describe the relations of this social practice and the notions of corporality, temporality and alterity among the studied subjects.

A discussion about music and anthropology introduces the thesis. The relation between music making and social intervention is the theme of the second chapter. A reflection about the specificity of music learning is done in the third chapter. Performance as identity-manipulation and transformation is discussed in the fourth chapter. The last chapter discusses the passage from "killing time" - the most common justification for participation in projects like Guri - and living it intensely. This is done with the analysis of the temporality of the subjects, the musical timing, and the relation between them.

Two videos - Prelúdio (Prelude) and Microfone, senhora (Microphone, madam) - are part of the thesis. They are audiovisual ethnographies, which, for their polyphonic and interpretative potential, dialogue with the text, allowing the reader/ spectator other reading, enjoyment and criticism possibilities for the material investigated.

Keywords: anthropology of music; visual anthropology; anthropology of the senses; performance; social intervention projects for childhood and youth 


\section{A MúsICA E O RISCO}

\section{Uma etnografia da performance musical entre crianças e jovens de baixa} renda em São Paulo

A pesquisa consiste na abordagem antropológica de um projeto institucional de ensino musical para crianças e adolescentes de comunidades de baixa renda no Estado de São Paulo (Projeto Guri), alguns destes, internos na Febem. A etnografia tem como objeto as diversas facetas do fazer musical, como seus aspectos pedagógicos e performáticos, e procura descrever as relações desta prática social com a construção das noções de corporalidade, temporalidade e alteridade entre seus sujeitos.

Uma discussão sobre as interseções entre música e antropologia introduz a tese. A relação entre prática musical e intervenção social é tematizada no segundo capítulo. Uma reflexão sobre a especificidade do aprendizado musical tem lugar no capítulo três. A performance como espaço de manipulação de identidades e de transformação é abordada no quarto capítulo. O último capítulo discute a passagem entre "matar o tempo" - principal justificativa para o ingresso em projetos como o Guri - e vivê-lo intensamente, a partir da análise da temporalidade dos sujeitos pesquisados, do tempo musical e da relação entre estes.

Dois vídeos - Prelúdio e Microfone, senhora - integram a tese. São etnografias audiovisuais, que, por seu potencial polifônico, polissêmico e interpretativo, dialogam com o texto, fornecendo ao leitor/expectador outras possibilidades de leitura, fruição e crítica do conteúdo por mim investigado.

Palavras-chave: antropologia da música; antropologia visual; antropologia dos sentidos; performance; projetos de intervenção social para a infância e juventude 


\section{AGRADECIMENTOS}

Escrever uma tese é, às vezes, um trabalho solitário. Felizmente, nem sempre. O processo de pesquisa envolve muita gente: os sujeitos pesquisados, os professores e colegas, os amigos e a família. Gostaria de agradecer a todos, que ora compartilharam comigo descobertas, ora compartilharam com o tempo para a pesquisa o tempo de nossas vidas.

Sylvia Caiuby Novaes tem me mostrado as possibilidades da pesquisa em antropologia desde a graduação em Ciências Sociais. Com ela, li algumas das primeiras etnografias, descobri a imagem como objeto de investigação (no mestrado) e como instrumento de pesquisa (neste doutorado). Pesquisadora curiosa e aberta, Sylvia sempre sugere caminhos pouco trilhados: a antropologia visual, a investigação das manifestações sensíveis, a arte iluminando a antropologia. Com Sylvia, a passagem da investigação da imagem à música não foi um grande salto, mas uma trilha gostosa de percorrer. Professora, orientadora e amiga, Sylvia me ensinou os caminhos da pesquisa com enorme liberdade.

Meus pais, Marta e Júlio Hikiji, sempre incentivaram todas as minhas escolhas, desde o aprendizado musical aos cinco anos, até a incursão pelo jornalismo e, finalmente, a antropologia. Neste doutorado, seu apoio foi fundamental. No primeiro ano da pesquisa, tornaram-se avós, e graças à sua presença cotidiana, dividindo os cuidados e carinhos com o Pedro, pude continuar trabalhando, com o coração tranqüilo.

Pedro acompanhou-me na pesquisa desde sempre. Ainda na barriga, ia comigo às oficinas na Febem e às saídas com os jovens. Depois de "grande", ouviu um pouco da história dos "meninos presos" - e se assustou. Dividiu sua mamãe com o "doutorado", palavra que o papai lhe ensinou nos últimos meses da escritura da tese, na tentativa de explicar as minhas ausências. 
Eduardo Jordão Neves, o "papai” e querido companheiro, tem compartilhado comigo as experiências mais diversas: aprendemos juntos a ser dois, a ser pais, a ser uma família. Pesquisador de outra área, Eduardo me mostrou, com sua experiência, a seriedade e o envolvimento necessários para a atividade acadêmica. Sempre me incentivou, e, nos momentos mais difíceis, esteve ao meu lado, às vezes literalmente, para que o trabalho não emperrasse.

Pude contar por quatro anos com o apoio da Fundação de Amparo à Pesquisa do Estado de São Paulo - FAPESP, que também financiou viagens para congressos, a compra de equipamentos, livros e de todo o material necessário para desenvolvimento da pesquisa.

Aprendi neste doutorado o significado de ter uma companheira de pesquisa. Ato geralmente solitário - Malinowski chegando na ilha -, a pesquisa pode ser bastante estimulante quando realizada em conjunto. Paula Miraglia esteve comigo nas primeiras visitas à Febem, realizamos juntas as oficinas de vídeo nessa instituição, refletimos e escrevemos artigos a quatro mãos (muitas vezes, intercalamos a escrita com as mamadas do Pedro, que logo passou a chamá-la de "tia Pauli”). Parte importante do que apresento nesta tese é resultado dessa parceria.

Os professores John Cowart Dawsey e Tiago de Oliveira Pinto contribuíram imensamente com esta tese. Além das sugestões fundamentais no exame de qualificação, pude contar com ambos como interlocutores em diversos momentos da pesquisa.

Foram vários os professores com quem pude compartilhar as questões desta pesquisa. Paula Montero discutiu comigo o projeto, momento importante de definições de objetivos. José Guilherme Cantor Magnani me ajudou com o universo do lazer. Os cursos ministrados por Teresa Caldeira e por John Cowart Dawsey foram fundamentais para a elaboração de questões importantes da tese. Partes do trabalho foram debatidas de forma bastante construtiva em aulas, seminários ou congressos por Rafael Menezes Bastos, Tiago de Oliveira Pinto, Deise Lucy Montardo, Fernanda Peixoto, Ana Lúcia Pastore Schritzmeyer, entre outros. Clarice Peixoto levantou questões instigantes sobre o uso do vídeo na pesquisa.

Um grupo de jovens antropólogos (em 1997 ainda mais jovens...) me 
convidou um dia para integrar o corpo editorial da revista Sexta Feira - antropologia artes humanidades. Jamais imaginei o que podia significar esse convite. Com Evelyn Schuler, Florencia Ferrari, Paula Miraglia, Paula Pinto e Silva, Renato Sztutman, Silvana Nascimento, Stélio Marras e Valéria Macedo, amigos queridos, tenho o privilégio de poder discutir e fazer antropologia com prazer, aos gritos, com festa.

De forma diversa, cada um dos membros desse corpo ajudou a constituir o corpo desta tese. Paula Miraglia, Renato e Stélio leram capítulos e fizeram sugestões e críticas importantes. Florencia deu forma ao conteúdo, além de me acalmar com sua praticidade nos momentos de finalização do trabalho. Silvana me ajudou a entender o prazer de fazer música em conjunto (nossos duos fazem parte da trilha sonora deste trabalho). Evelyn, Val e Paulinha compartilharam, dentre outras, as aventuras de ser antropóloga e mãe.

Outro espaço no qual aprendo muito - desde o mestrado - é o Grupo de Antropologia Visual (GRAVI-USP). Com o início do Projeto Temático Imagem em Foco nas Ciências Sociais, apoiado pela FAPESP, o grupo cresceu, produções interessantes surgiram, e ganhou espaço a discussão - fundamental para este trabalho - da imagem como instrumento e resultado da pesquisa. Agradeço a todos os colegas com quem pude compartilhar a experiência de pensar e produzir imagens: aos professores Sylvia, Miriam Moreira Leite e Paulo Menezes; a Gianni Puzzo, mestre nas artes de montar imagens: sua parceria foi fundamental para a realização dos vídeos que integram a tese; a Ana Lúcia Ferraz, que também nos emprestou sua câmera para as oficinas da Febem, antes das aquisições do Temático; a Andréa Barbosa, Aristóteles Barcelos Neto, Chico Paes, Denise Dias Barros, Edgar Teodoro da Cunha, Florencia Ferrari, Francirosy Ferreira, Joon Kim, Lucas Fretin, Maira Bühler, Omid Burgin, Paula Morgado, Priscilla Ermel, Renato Sztutman, Rita Castro, Stélio Marras e Yara Schreiber, companheiros de discussões práticas e teóricas sobre antropologia visual.

Trabalhar com imagens envolve um suporte técnico imenso. O Laboratório de Imagem e Som em Antropologia (LISA-USP), coordenado por Sylvia Caiuby Novaes, nos oferece, além desse suporte, um ambiente de trabalho que 
faz das horas na ilha de edição momentos menos isolados do que se poderia supor. Pude contar com Mariana Vanzolini em inúmeros momentos da pesquisa. Seu apoio na reprodução dos vídeos, textos e outras imagens que compõem a tese foi fundamental. Sempre presente no cotidiano do laboratório, Mariana pôde assistir as primeiras versões dos vídeos, discutindo problemas e soluções não apenas técnicos. Com Paula Morgado, além de compartilhar a experiência de finalizar uma tese, pude contar em várias situações da pesquisa. Sua presença no LISA e junto ao GRAVI é determinante no encaminhamento de nossas atividades de pesquisa. André Oliveira e Luciara Garcia completam o time que viabilizou, com muita disposição, a produção dos vídeos.

Junto ao Núcleo de Antropologia Performance e Drama (NAPEDRA) da USP, coordenado por John C. Dawsey, desenvolvi reflexões essenciais para esta tese. Agradeço ao John e aos colegas que compartilharam as leituras sobre antropologia e performance: André-Kees, Camila Vieira, Carolina Abreu, Danilo Ramos, Eufrázia Santos, Francirosy Ferreira, Giovanni Cirino, Luena Pereira, Maria do Socorro Lima, Marianna Monteiro, Rita Castro, Rubens Alves da Silva, Vanilza Rodrigues, Wladimir Blos.

Ivanete Ramos Roza, Rose Inácia de Oliveira, Celso Cunha Gonçalves, Ednaldo Faria Lima e Soraya Gebara são funcionários do departamento de Antropologia com quem podemos efetivamente contar. Agradeço a eles, ao Departamento de Antropologia e ao Programa de Pós-graduação em Antropologia Social da USP.

Sem o apoio de Maria José Costa Lima, com a casa, comigo, com o Pedro, o trabalho seria impossível.

Carmen Novo, querida amiga e artista plástica, concebeu a capa da tese, em correspondências virtuais dada nossa distância espacial.

Com minha irmã, Juliana Gitirana Hikiji, a "tia Ju”, sempre pude contar: para os dentes, para a música, para o Pedro, para a vida!

Música - o objeto desta tese - sempre fez parte de minha vida. Nos últimos anos, alguns professores foram responsáveis pelo aprofundamento de meu conhecimento e paixão pela atividade musical. Agradeço a Luciana Rosa, Ricar- 
do Fukuda, Teresa Cristina Rodrigues da Silva e Meryelle Maciente por tudo o que tenho aprendido em música com as aulas de violoncelo.

Por fim, agradeço especialmente aos alunos, professores e coordenadores do Projeto Guri, que, desde 1998 têm recebido essa perguntadora, compartilhado comigo seus sonhos e projetos. Dentre os alunos, encontrei em Alessandra Cristina Raimundo e Valdir Vale Maia grandes interlocutores. Os maestros Valter Batista de Azevedo (“Asa”), Regina Kinjo, Emiliano Patarra e João Maurício Galindo compartilharam comigo suas experiências, ensaios e aulas. Ângela Maria Visconti, Elizabeth Parro, Silvana Cardoso e Nurimar Valsecchi, da coordenação Projeto Guri, deram todo o apoio necessário à pesquisa. As coordenadoras de pólo Ana Laís Parro dos Santos (POF/Morumbi) e Helena de Fátima Moura (Mazzaropi) foram importantes colaboradoras.

Várias pessoas disponibilizaram seu tempo em entrevistas longas, que me foram valiosas. Agradeço a Melanie Farkas, da Sociedade dos Amigos do Projeto Guri; a Inaiá Feliz Pereira, Maria Corina Gama de Macedo, Saulo Garroux e Dagmar Rivieri Garroux, a “tia Dag”, da Casa do Zezinho; a Luciana Guimarães, do Instituto Sou da Paz.

Rosemary dos Santos e Elza Tavares Bezzerra, diretora e coordenadora pedagógica da área de Arte e Cultura da Febem, abriram as portas da casa dos Projetos Especiais para esta pesquisa. Lá, sempre me receberam com muita atenção. Foram elas que me apresentaram aos "meninos", forma carinhosa como chamam aos internos, devolvendo-lhes alguma dignidade.

Deco, PMC, Suave e Vila, do grupo de rap Jigaboo desenvolveram um belo projeto com os jovens da Febem, que é parcialmente registrado no vídeo Microfone, senhora.

Agradeço especialmente aos meninos, que nas oficinas de vídeo, nas aulas de música ou nas saídas para apresentações compartilharam comigo seu talento e suas inquietações, matéria prima da reflexão que procurei tecer.

Rose Satiko

dezembro, 2003 


\section{ÍNDICE}

Abertura

I. Das possibilidades de uma audição da vida social [música e antropologia - e um pouco de teatro, cinema...]

II. Música como intervenção social [música e política]

III. Etnografia do aprendizado musical [música, imersão, mimese e corporalidade]

IV. Etnografia da performance [música, identidade e transformação]

v. Tempo de vida, tempo musical [música e temporalidade]

Considerações finais - [de]composição

Notas

Bibliografia

Filmografia

Vídeos que integram a tese - ficha técnica 
A mãe canta para ninar o bebê. Acalento. Recria, com a voz, o aconchego uterino. Lá, eram as batidas do seu coração a música cotidiana: o ritmo como base de todas as percepções ${ }^{1}$.

O maestro Daniel Barenboim defende a educação musical como meio de formação da criança, não só em música: "Para tocar bem música, você precisa estabelecer um equilíbrio entre cabeça, coração e estômago. E, se um dos três não está presente ou está presente demais, você não pode usá-lo” (Barenboim e Said, 2003: 41). Barenboim percebe na fruição musical a possibilidade de, "por um lado, escapar da vida e, por outro, entendê-la muito melhor que em muitas outras disciplinas" (idem: 42).

Ao sugerir a música como meio de apresentar a condição humana a uma criança, Barenboim intui ou pressupõe a qualidade musical de atuar simultaneamente nas esferas da Natureza e da Cultura. O equilíbrio entre "cabeça, coração e estômago”, de que fala o maestro, remete ao que Claude Lévi-Strauss percebeu como a dupla ancoragem da música: além do cultural, ela opera no molde natural, ao dirigir-se ao tempo psicológico, fisiológico e até "visceral" do ouvinte. É dessa atuação simultânea que a música retira seu poder extraordinário de agir sobre "o espírito e os sentidos", de mover "idéias e emoções" (Lévi-Strauss, 1991: 35). 
Adentrar o universo da música sem abrir mão dos sentidos ou do espírito - esse iluminado pela antropologia, sobretudo. Foi esse o caminho que escolhi para percorrer os significados do fazer musical entre crianças e jovens participantes de um projeto estadual de ensino de música destinado à população de baixa renda em São Paulo. Na etnografia, discuto as diversas facetas do fazer musical observado [e sentido], como seus aspectos pedagógicos, políticos e performáticos, e procuro descrever as relações dessa prática social com a construção das noções de corporalidade, temporalidade e alteridade entre seus sujeitos.

Essa pesquisa é impulsionada por uma constatação, uma paixão e algumas perguntas. Aquele que observa no cenário nacional a questão da infância e juventude "em situação de risco" não escapa do crescente número de projetos dedicados a essa população, baseados na oferta do ensino artístico, seja via música, dança, teatro ou artes plásticas. As propriedades da "arte-educação" como forma de "recuperação", "inserção", ou "terapia” vem sendo defendidas e praticadas em diversos projetos que ganham visibilidade nos últimos anos em nível nacional e internacional. A música é a base de alguns dos principais projetos voltados para o público em questão.

É também objeto de interesse pessoal: desde os cinco anos, quando comecei a estudar violão, nunca deixei de tentar fazer música. O dado biográfico é ressaltado, uma vez que é fundamental no exercício interpretativo que constitui essa pesquisa, bem como o foi no surgimento da curiosidade que a impulsiona. Foi por meio da minha primeira professora de violoncelo que conheci o projeto que enfoco. Enquanto me envolvia com o instrumento, sua sonoridade e repertório, conhecia - pelo relato emocionado da professora - histórias de meninos presos, seus alunos, que também se apaixonavam pela música.

Essa coincidência prática e sentimental, que me unia ao interno da Febem, foi o impulso à reflexão: Qual a especificidade do aprendizado musical? Por que e como a música seduz e envolve seus praticantes? Que experiências o fazer mu- 
sical possibilita aos sujeitos definidos (pelo outro) pela carência, pela falta, pela negação? Como e por que a música veio a ocupar um lugar de destaque dentre os projetos sociais voltados à "questão do menor"?

Em 1998, conheci o Projeto Guri, iniciativa da Secretaria de Estado da Cultura de ensino de música por meio de orquestras didáticas e corais para público prioritariamente de baixa renda ${ }^{2}$. O projeto oferece aulas de canto e/ou

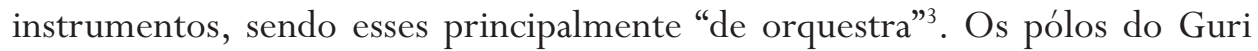
têm orquestra, camerata e/ou corais. Após algum tempo de aula (em alguns casos, um mês), os alunos podem participar de um dos conjuntos.

Na pesquisa de campo então iniciada, em dois pólos do Projeto, surgiram questões que me fizeram optar por um olhar vertical ao universo do aprendizado musical, por meio de estudos de caso nos pólos. A opção pela observação de um único projeto, em detrimento de uma análise comparativa que levasse em conta outras situações de prática musical, não implicava, porém, uma abordagem institucional, como pretendo mostrar. Em suma, o foco não seria “o Projeto Guri”, mas a prática musical, que tem sua especificidade dada a proposta do Guri, mas também uma espécie de transversalidade: olhar para a relação dos jovens desse projeto com a música revela a prática musical como atividade simbólica de forma ampla, que ganha contornos específicos dadas as faixas etária e social de seus atores.

A escolha do fazer musical como objeto de reflexão antropológica levava à opção por uma abordagem sensivel do cotidiano. Foi preciso investigar as possibilidades de interpretação da vida social a partir da experiência musical. Toda a tradição visual das ciências sociais e das humanidades - que enfatiza a observação, as perspectivas, os pontos de vista (cf. Caiuby Novaes, 2002) - colocava como questão a viabilidade de uma audição da vida social como alternativa ou complemento à sua leitura. Tais questões aproximaram essa pesquisa de áreas como a etnomusicologia, a antropologia da performance e dos sentidos, que são abordadas no primeiro capítulo da tese: Das possibilidades de uma audição da vida social [música e antropologia - e um pouco de teatro, cinema...].

Diante de um projeto como o Guri, era necessário entender de que forma 
a música se configurava como instrumento de intervenção social. Foi preciso ambientar a pesquisa no campo da reflexão sobre a infância e juventude brasileira. Os atores da pesquisa - ou músicos, melhor dizendo - são crianças e jovens aos quais diversos setores da sociedade vão atribuindo classificações, denominações, enquadramentos, enfim, identidades que nem sempre correspondem às imagens pelos mesmos construídas. Do ponto de vista institucional, aos olhos dos proponentes dos projetos, são "carentes" - e não apenas no sentido financeiro: “carência afetiva, carência de família, carência de atenção, de afeto, de carinho" é o que aproxima os diversos alunos do Guri, pobres ou não, nas palavras de uma de suas coordenadoras. São, portanto, para a instituição, sujeitos definidos pela falta, e a música é, nesse sentido, chamada a completá-la.

Sob outro ângulo, os jovens participantes do Guri encaixam-se na ampla categoria "infância e adolescência em situação de risco", que, como "menor", “carente”, ou "menino da Febem”, é construída historicamente e precisa ter seus termos analisados. Importante marco na história da infanto-adolescência no Brasil é a aprovação do Estatuto da Criança e do Adolescente (ECA), em 1990, que aglutina reflexões inovadoras sobre a situação das crianças e jovens no país e passa a pautar políticas públicas e projetos do terceiro setor para esse grupo populacional. A prática musical, concebida como forma de "recuperação", "educação", "formação" ou "ocupação", constitui-se em mais um elemento de identidade, que é apropriado pelos jovens em formas e contextos diversos. Essas relações entre prática musical e intervenção social são abordadas no segundo capítulo da tese: Música como forma de intervenção social [música e política].

Se os discursos introduzem o cenário da prática musical, é no cotidiano das aulas que esta se materializa. No capítulo Etnografia do aprendizado musical [música, imersão, mimese e corporalidade] procurei entender os mecanismos mobilizados na aquisição musical, como a leitura (visualidade), a audição, a imitação e a corporalidade. Na observação da aula, evidenciou-se a íntima relação entre transmissão de conhecimento musical e de valores. $\mathrm{Na}$ comunicação entre alunos, entre esses e professores, de todos com a música, procurei entender alguns dos sentidos do fazer musical para os jovens. A especificidade do aprendizado musical 
em uma situação de restrição de liberdade - o Guri na Febem - é abordada também neste capítulo. A relação entre musicalidade e corporalidade é ainda mais evidenciada nesse contexto, quando o corpo musical entra em confronto com o corpo vigiado.

A reflexão sobre a performance perpassa toda a etnografia. Mas é no quarto capítulo, Etnografia da performance [música, identidade e transformação], que o momento da apresentação - bem como as experiências que a antecedem e a sucedem - é analisado de forma mais detida. A performance é central em projetos que, como o Guri, tem como um dos objetivos principais a intervenção social por meio da música. Ela torna visíveis atores e instituição. Na performance, identidades são definidas. Na e para a performance, auto-imagens são construídas. A performance é espaço de transformação. Estar no palco possibilita um exercício único de alteridade. No Guri, a apresentação é concebida como auge do processo pedagógico, locus de exibição do que foi aprendido, ensaiado, incorporado. É oportunidade de conhecer novos lugares, pessoas, é "saída para o mundo", frase que ganha ainda mais intensidade quando pronunciada por quem foi retirado da convivência social. A etnografia de uma saída para apresentação de jovens internos na Febem Tatuapé encerra o capítulo.

O tempo é o tema do último capítulo da tese: Tempo de vida, tempo musical [música e temporalidade]. "Matar o tempo”, “ocupar o tempo ocioso” foram sempre as primeiras respostas que recebi à questão sobre o porquê da procura do aprendizado musical. A temporalidade que envolve os atores da pesquisa surgia como categoria a ser analisada. Ela determina ações, modos de pensar, de estar no mundo. A atribuição de valor negativo ao tempo livre - entendido como o período em que as crianças e jovens estão fora da escola - precisava ser entendida. No senso comum (de pais, proponentes, da mídia, da sociedade de forma ampla), o tempo "ocioso" é um tempo perigoso. É preciso "ocupar o tempo", é preciso "tirar da rua".

Sem ignorar o caráter muitas vezes ocupacional de projetos como o $\mathrm{Gu}$ ri, percebi a necessidade de pensar a especificidade da temporalidade do fazer musical. Discuto, neste capítulo, algumas relações da música com o tempo e 
certas propriedades do tempo da prática musical. Aproximo-o do tempo do jogo, caracterizado pela imersão e pela suspensão do cotidiano. Procuro entender, finalmente, como é possível que o tempo para a música, inicialmente um intervalo, transborde para o resto da vida cotidiana, passando a determinar o ritmo dos dias, a preencher momentos antes vazios, a solicitar cada vez mais dedicação, a fazer da música "tudo" na vida de uma criança ou jovem. A especificidade do jovem em situação de internação - marcada pela experiência do "tempo perdido” (cf. Goffman, 1974) - também é analisada. Nesse contexto, penso a música como possibilidade de interrupção e, eventualmente, de reflexividade.

\section{Dos sons às imagens - e vice-versa}

O presente trabalho marca uma passagem em minha trajetória de pesquisa em antropologia. No mestrado, tive como objeto a construção da violência como linguagem no cinema de ficção da década de 1990 (Hikiji, 1999). Do cinema à música, da pesquisa com documentos visuais à pesquisa de campo, o doutorado parecia uma ruptura radical.

O desenvolvimento da pesquisa mostrou a fragilidade dessa impressão. $\mathrm{O}$ tema do mestrado - a violência - surgia no doutorado com outra roupagem: urbana, real ou imaginada, a violência é parte constitutiva do universo dos sujeitos pesquisados. É o medo da violência que afasta crianças e jovens da rua, que faz necessária a ocupação do tempo livre. É o envolvimento com algum tipo de violência que leva outras crianças e jovens à Febem.

A música, como o cinema, é uma manifestação estética. Em nossa sociedade, ambos são parte do que chamamos "arte”. A reflexão sobre a relação entre arte e sociedade é, portanto, comum às duas pesquisas. Também a reflexão antropológica acerca das manifestações sensíveis, pela qual passei de alguma forma no mestrado, foi apropriada e aprofundada nesse momento.

A antropologia visual foi, no mestrado, o terreno a partir do qual desenvolvi toda a pesquisa. Desde o início da pós-graduação em antropologia, pude 
fazer parte do Grupo de Antropologia Visual da usp (Gravi-usp) que, em 1999, passou a desenvolver o Projeto Temático "Imagem em Foco nas Ciências Sociais", com o apoio da Fapesp ${ }^{4}$. Com os pesquisadores desse grupo, pude discutir desde a análise das imagens até sua realização, nos filmes, vídeos ou fotografias etnográficas. No doutorado, a participação no Temático me permitiu desenvolver dois aspectos importantes do trabalho: o vídeo como instrumento e como produto da pesquisa.

\section{oficinas de imagem: o vídeo como comunicação ${ }^{5}$}

Junto ao Temático, desenvolvi, com Paula Miraglia (então mestranda no PPGASusP), o projeto "Oficina de Imagens: uma reflexão sobre o processo de introdução da análise e produção videográfica entre internos da Febem". Nosso objetivo era a reflexão acerca das possibilidades e resultados da introdução da linguagem visual na pesquisa de campo com um grupo de jovens internos na Febem-Tatuapé.

A pesquisa de campo na Febem era um dos pilares do doutorado. Em 1999, pude realizar visitas semanais à instituição, assistir a aulas de música (canto, instrumento), ensaios (para apresentações), à gravação de um CD com um grupo de rap em um estúdio, apresentações dos internos em locais como o Memorial da América Latina e o Festival de Inverno de Campos de Jordão. Todas essas oportunidades foram importantes à pesquisa, mas a possibilidade de desenvolver uma atividade com os jovens (as oficinas de vídeo) foi, provavelmente, uma das melhores formas de acesso ao seu universo.

Minhas primeiras visitas à Febem se deram em 1998. Na época, o "Quadrilátero do Tatuapé” era a maior unidade da Febem no Estado de São Paulo, abrigando aproximadamente 1600 internos, todos do sexo masculino, entre 12 e 21 anos de idade. Os adolescentes eram divididos e agrupados em 14 unidades educacionais (uE) - hoje, chamadas de Unidades de Internação (uI). Nas ues, eles deveriam ser separados por gravidade da infração e idade, o que nem sempre ocorria em virtude da superlotação ou outros problemas administrativos. As unidades eram isoladas entre si, cercadas e com saída controlada. 
A partir de 1999, iniciei a pesquisa de campo de forma sistemática na Febem. Em várias oportunidades, dividi a experiência de pesquisa com Paula Miraglia. Nas primeiras visitas, nosso contato com os jovens era muito restrito. Quando assistíamos às aulas do Guri, tínhamos pouco tempo para conversar com os meninos: alguns minutos antes da aula, ou, logo depois, antes que retornassem às unidades. A orientação que tivemos era de nunca falar sobre os crimes ou motivos que os levaram à instituição. De uma forma geral, éramos sempre "vigiadas" no contato com os jovens. Nas ocasiões em que pudemos visitar algumas das ues, éramos sempre guiadas por um funcionário.

Nesse sentido, vislumbramos na criação das oficinas uma nova forma de entrada na instituição. A partir de nosso contato com a coordenação de Projetos Especiais - responsável pelo Projeto Guri na Febem -, propusemos uma "oficina" de discussão e realização de vídeos.

A oficina, para nós, era também uma tentativa de romper com as dificuldades impostas pelo estranhamento que caracterizava nossa relação com o grupo: éramos mulheres em um universo masculino; fazíamos parte de um grupo que é potencialmente "vítima" da violência que os condena à internação; não tínhamos um "papel” institucional que "justificasse" para os internos nossa presença no Quadrilátero. Percebemos na oficina - atividade semanal que garantiria o vínculo com um mesmo grupo por alguns meses - uma forma de ganhar um lugar no cotidiano dos jovens.

A participação efetiva no cotidiano da internação, por meio da função de “oficineiro", nos permitia, além da observação, a interação com o grupo. A partir de então novas identidades eram somadas a de pesquisadoras: para a instituição éramos voluntárias, trabalharíamos com os jovens internos e contribuiríamos para a ocupação do tempo dos mesmos; para os jovens éramos pessoas dispostas a transmitir um conhecimento, sem vínculo empregatício com a instituição, o que favorecia a criação de uma relação menos desconfiada.

As oficinas transcorreram entre junho e setembro de $1999^{6}$. Em geral, aconteciam uma vez por semana, em sessões de duas horas, com cerca de oito internos. A seleção era realizada pela própria Febem em unidades diversas. Não fizemos 
restrições quanto à idade ou escolaridade. A duração prevista era de três meses ${ }^{7}$.

O primeiro desafio enfrentado na Oficina foi o de vencer a perspectiva utilitária com a qual a instituição caracteriza as atividades oferecidas aos jovens ${ }^{8}$. Nosso projeto estava inserido no programa da Escola-oficina, que é responsável pela coordenação do ensino fundamental e médio (obrigatório) e por uma série de atividades ditas profissionalizantes ou de lazer, oferecidas em espaços geralmente externos à $\mathrm{UE}^{9}$. Nos primeiros encontros que tínhamos com os jovens, éramos freqüentemente questionadas sobre o caráter da oficina: ora tivemos que explicar que não era um curso para aprender a consertar vídeo, ora que justificar a inexistência de um certificado de conclusão. Precisávamos deixar claro que não estávamos lá para formar técnicos: nosso objetivo era introduzir a linguagem e os instrumentos do fazer imagético, pensando-os como ferramentas reflexivas, que os estimulassem não só a conhecer uma nova forma de comunicação, como a pensar sua situação por meio dessa linguagem.

A oficina consistia basicamente na exibição e discussão de vídeos com os grupos $^{10}$, no exercício de técnicas básicas de manuseio de equipamento para captação de imagens e sons em vHs e Hi-8 e na realização de algumas narrativas audiovisuais. Nas primeiras aulas, percebemos haver um repertório compartilhado de representações entre os jovens cujos pilares eram a câmera e um determinado tipo de narrativa videográfica.

O objeto-câmera fascinava nossos alunos. Uma das primeiras atividades que propúnhamos na oficina era a apresentação da câmera. Mostrávamos seus componentes, suas operações básicas e ela era então passada de mão em mão, até que todos tivessem-na experimentado. Alguns afirmavam já conhecer uma câmera de vídeo ("eu roubei uma”), outros queriam saber quanto custava. Nas falas curiosas, evidenciava-se a atração causada pelo aparelho eletrônico, de alto valor monetário e também simbólico. "Conhecer uma dessas”, saber usá-la e, no limite, possuí-la era sinal de status e poder. Fazer a oficina era, nesse sentido, uma possibilidade nítida de diferenciação com relação ao grupo de internos.

A câmera era também o principal instrumento mediador de nossa relação com os internos. Em nossas primeiras conversas com os grupos, sugeríamos co- 
mo exercício que eles se apresentassem para a câmera. Em seguida, exibíamos o material gravado para o grupo e discutíamos da qualidade da captação à postura e voz dos "apresentadores". Assim, nossa introdução no grupo era mediada pelo equipamento e isso teve conseqüências relevantes.

O tipo de atividade que estávamos propondo estimulava de forma peculiar a fala de nossos sujeitos. Os exercícios de depoimentos para a câmera e de grupos de entrevista - os primeiros que sugeríamos na oficina - eram realizados com empolgação pelo grupo. O vídeo era rapidamente associado à possibilidade de narrar a experiência da internação. Falar para a câmera era substancialmente diferente de conversar com uma pesquisadora. O formato "depoimento" ou "entrevista" (no qual um dos jovens era o repórter, outro, o entrevistado e o terceiro, o câmera) dava aos internos a possibilidade de domínio sobre o conteúdo da fala: eram eles e não nós quem escolhia o que falar.

O fato de estar à frente da câmera tem conseqüências subjetivas importantes que são otimizadas dada a situação da internação. Por um lado, a maioria dos internos na Febem pertence a camadas de baixa renda, com pouco acesso a espaços de expressão. Por outro, a internação é caracterizada por um processo de esquecimento dos seus sujeitos. É nesse cenário que precisa ser pesada a importância de estar à frente da câmera. Falar para o vídeo é marcar uma presença, expor a sua condição, abandonar por momentos a invisibilidade que os caracteriza, deixar registrada sua existência, sua revolta.

Estar atrás da câmera era também um ato peculiar dada a situação de internação. Para começar, o fato de terem em suas mãos o equipamento das pesquisadoras - que sempre ressaltamos ser nosso e único - indicava aos mesmos a confiança que tínhamos neles. A manipulação da câmera era, no limite, uma ação independente, pouco comum no ambiente institucional. A escolha do que filmar era livre, dentro dos limites impostos pelo espaço e duração das aulas. Essa liberdade tinha como resultado desde a escolha das "pautas" e entrevistados, até o uso não previsto e desafiador do equipamento, como a gravação em zoom de partes do corpo de uma funcionária. Por fim, o domínio da técnica básica de captação de imagens os fazia autores: com a câmera, criavam narrativas que eram exibidas 
e comentadas com o grupo.

Os exercícios de produção de imagens revelaram também a forma como os jovens relacionam-se com as imagens midiáticas. Apesar de nossa insistência na produção de narrativas com alguma liberdade formal (e até mesmo ficcionais), a maioria das produções dos alunos era inspirada no discurso e forma dos telejornais mais sensacionalistas, os mesmos que ao cobrir as rebeliões na Febem as descreveriam de forma melodramática, exaltando o perigo, o medo, a falta de controle da situação e referindo-se aos internos como "menores", "bandidos", "animais", "marginais".

A encenação da reportagem contava com dois personagens: de um lado o "entrevistador" - que na maioria das vezes reproduzia as expressões e trejeitos dos repórteres do telejornal Cidade Alerta, da Rede Record, apresentado por Datena ${ }^{11}$; de outro, um "interno da Febem", sempre tratado pelo "repórter" por "menor fulano". Na pauta, eram recorrentes temas como criminalidade, o percurso até a Febem, as condições da internação, a visão da "sociedade" sobre a instituição e os planos para o futuro.

$\mathrm{Na}$ construção do personagem “interno" eram expostos aspectos que compunham a identidade do grupo, mas não necessariamente por meio de uma história de vida específica, uma perspectiva individual. A noção de encenação é essencial para descrever o processo criativo e o tipo de comunicação que se estabelecia por meio das imagens. Os personagens encenados condensavam uma série de características do que se imagina ser o interno da Febem. Ao invés de deixarem a câmera registrar suas próprias histórias pessoais, os jovens narravam histórias imaginadas, incorporavam personagens baseados ora em um senso comum sobre quem é o interno da Febem, ora nas experiências concretas vividas no cotidiano da internação. As histórias dos "entrevistados” criados não diferiam completamente de suas próprias histórias, mas o distanciamento proporcionado pela encenação permitia um certo devaneio e a garantia de alguma privacidade.

A experiência da encenação pode ser aproximada do que Maria Filomena Gregori (1997) chama de viração, um tipo específico de sociabilidade dos "meninos de rua”, onde crianças e jovens jogam com a alternância de papéis, mistu- 
rando suas experiências de vida com as representações sociais a eles atribuídas. Como a viração, a encenação permitia aos jovens ocupar lugares diversos: ora eram vítimas de maus-tratos, ora criminosos experientes, ora jovens recuperados prontos para o retorno ao convívio social.

Mas, por outro lado, a construção das reportagens resultava numa ficção perversa e irônica: a escolha dos personagens - o repórter sensacionalista e o interno genérico - reificava os estereótipos sociais que estigmatizam o jovem interno. Para narrar suas histórias, elegiam justamente uma figura conhecida do público pelo tratamento discriminatório e maniqueísta dirigido aos jovens em conflito com a lei. Se, por um lado, havia uma ironia na capacidade de manipular essas representações e valores, por outro, estava explícita a fragilidade da condição de interno: não conseguiam falar de si sem usar uma narrativa que tradicionalmente os estigmatiza.

Em síntese, as oficinas vieram a ser um momento privilegiado do fazer etnográfico. A oportunidade de presenciar esse exercício de papéis, de síntese de relações, de dramatização do cotidiano veio a ser um instrumento único de investigação. Éramos propositoras e expectadoras de uma performance, cuja dramaturgia e encenação eram resultado de uma síntese de elementos cuidadosamente selecionados pelos autores no universo simbólico da experiência de internação.

\section{$o$ vídeo em campo}

As oficinas foram a primeira experiência com os meios de comunicação audiovisual da pesquisa. Mas não a única. Decidi levar câmera e microfone às saídas para apresentações, tanto dos jovens da Febem, quanto do Mazzaropi, outro pólo no qual realizei pesquisa de campo ${ }^{12}$. Entre agosto e dezembro de 2000, acompanhei as atividades do Guri na Oficina Cultural Amácio Mazzaropi, que fica no Brás. Em visitas semanais, assisti a diversas aulas, ensaios, entrevistei e conversei com alunos, professores, pais, coordenadores. Acompanhei apresentações em locais como o Memorial da América Latina, a Sala São Paulo ou o Anfiteatro Camargo 
Guarnieri, na usp. Levei a câmera de vídeo a todas as apresentações, experimentando estratégias de interação visual com o grupo. O clima da performance (desde a saída do pólo, passando pela preparação nos camarins, a apresentação, até a volta ao pólo) era propício à presença da câmera. Uma das estratégias que utilizei desde as primeiras saídas com o equipamento foi a escolha de alguns dos jovens e crianças que já conhecia das aulas para serem “entrevistadores”. Também entrevistei alunos e professores, e gravei imagens das apresentações, desde os momentos iniciais - chegada ao palco, camarotes, ensaio geral - até o concerto propriamente dito.

Os resultados do uso da câmera no processo de pesquisa foram diversos. Entre os alunos mais jovens (crianças de até 13, 14 anos) o vídeo despertava a curiosidade, mas o recurso da entrevista resultava, muitas vezes, em respostas repetidas, curtas, quase inconseqüentes. Entre os mais velhos (14 a 19 anos, aproximadamente), a entrevista em vídeo estimulava a elaboração de reflexões rápidas sobre a situação que estavam vivendo. Quase sempre, a referência comunicativa era a linguagem dos noticiários de Tv: respondiam ao entrevistador (que podia ser a pesquisadora ou um colega) como a um repórter. Mas conforme o tempo da entrevista se estendia, o vídeo podia tornar-se um momento de reflexão, vitrine de idéias, ideais, espaço de sonho. Falava-se em expectativas (quando o entrevistador é um aluno, sempre surge a questão da música como carreira), refletia-se sobre o momento vivido, valorizava-se a atividade (além de uma apresentação, era uma apresentação que estava sendo acompanhada por alguém com uma câmera de vídeo...).

Percebi, após várias saídas com a câmera, que o recurso da vídeo-entrevista aproximava pesquisadora e pesquisados, estimulava a interação, era pretexto para a conversa. Por outro lado, a observação do material registrado revelava os limites do próprio recurso: a expressão verbal nem sempre dava conta do fenômeno musical. Como traduzir em palavras a sensação de ter estado no palco há poucos minutos? Como verbalizar o significado do fazer musical? Era difícil ir além do "legal”, "é tudo", "eu gosto”. A observação revelou que muitas das respostas à questão sobre o sentido da prática musical não seriam encontradas 
no universo da palavra, da reflexão, da razão. O gesto, as expressões corporais, a emoção podiam mostrar mais. E o gesto podia ser observado - e também ser registrado em vídeo. O vídeo, por vezes, registrava até o que não fora apreendido pelo observador. Rever as imagens foi fundamental na análise da corporalidade, do gestual que constitui o fazer musical em questão.

O vídeo "Prelúdio", parte integrante dessa tese, resulta da experiência da captação - e posterior montagem - de imagens, sons e entrevistas nos momentos de performance do Projeto Guri. O vídeo apresenta alguns dos sentidos do fazer musical para as crianças e jovens que pesquisei, ora verbalizados, ora apenas sugeridos nos gestos, expressões corporais, acordes que acompanham um movimento. Após algumas exibições do vídeo para jovens que o protagonizam ou para colegas pesquisadores, pude notar seu potencial expositivo (no sentido de explicitar algumas idéias resultantes de minha análise do projeto de ensino musical em questão), sensível (quando evidencia os fatores não racionais envolvidos na prática musical) e comunicativo (a partir do vídeo, pude apresentar para os espectadores - pesquisados ou pesquisadores - minha própria pesquisa de forma muito mais clara).

O vídeo é, portanto, parte constitutiva do processo da pesquisa. Se a captação de imagens e sons é importante instrumento de comunicação com os jovens, a edição dos vídeos ${ }^{13}$ é um processo reflexivo único. A decupagem (descrição minuciosa do conteúdo), a elaboração de um roteiro, a seleção de trechos significativos de entrevistas, a observação atenta das imagens e, finalmente, a construção de uma narrativa resultam em uma reflexão densa sobre o objeto, na elaboração de temas relevantes da pesquisa, em um olhar novo aos sujeitos pesquisados.

Encerro essa abertura já bastante extensa com algumas observações sobre o processo de realização do vídeo Microfone, senhora, que ecoa em momentos diversos da análise. Em tempo: sugiro que o leitor assista aos vídeos nesse momento, antes de continuar a leitura da tese. 


\section{Microfone, senhora}

Domingo, 27 de julho de 1999. Chegávamos, mais de vinte jovens internos na Febem, alguns monitores e eu, a um estúdio de som na zona Norte de São Paulo para gravar uma faixa do CD “As aparências enganam”, do grupo de rap Jigaboo. Os protagonistas da gravação eram os jovens. Os monitores os acompanhavam, assim como uma pequena escolta policial (obrigatória em qualquer saída de internos da sede da Febem). Eu levava uma pequena câmera Hi-8 (palm cam), fone de ouvido e microfone de mão. As razões para carregar o equipamento eram, para mim, um tanto nebulosas ainda. Sem dúvida, eu apostava no potencial da câmera como instrumento de pesquisa, vislumbrava um dia poder produzir algum material audiovisual como resultado da pesquisa, mas, naquele momento, tudo eram suposições, e o que eu podia fazer era aproveitar a boa vontade de funcionários ligados à área de arte-educação da Febem, que permitiram minha presença nesse e em outros eventos com a câmera.

Coloca o microfone pra nós zoar. Dá para fazer uma reportagem a pampa.

Microfone, senhora!

Uma frase, um pedido, uma brincadeira. Alguns segundos que deram sentido ao esforço de pedir uma câmera emprestada, de camuflá-la na entrada da Febem (fui orientada por funcionários a esconder a câmera, porque seria uma enorme burocracia entrar com o equipamento na instituição), enfim, de apostar naquele potencial instrumental da câmera de vídeo. João ${ }^{14}$, um dos internos mais ve$\operatorname{lhos}^{15}$, me observava gravando imagens desde a entrada no ônibus no qual saímos da Febem. Gravei a descida do ônibus e a entrada no estúdio. Nesse momento, na porta do estúdio, João proferiu a frase que uso na abertura do vídeo e que o nomeia: "Microfone, senhora!". O pedido espontâneo e inusitado desencadeou uma série de ações e reflexões - deles, minhas - que pretendo aprofundar aqui.

Quando acompanhei a gravação do CD, em julho de 1999, já havia realizado algumas oficinas de vídeo e acompanhado, com a câmera, uma viagem a Campos 
de Jordão, quando os jovens internos foram participar do Festival de Inverno, como membros do coral do Projeto Guri. Daí, a facilidade relativa de "entrar com o vídeo” na Febem. No entanto, a atitude de João, de assumir espontaneamente o microfone e conduzir uma reportagem, era inédita. Nas oficinas, sempre propúnhamos que os jovens realizassem entrevistas (tendo como entrevistados seus colegas, ou funcionários da Febem ${ }^{16}$ ), e essas eram feitas como exercícios para treinar a linguagem audiovisual. João não participou das oficinas de vídeo, mas vislumbrou - e verbalizou - a possibilidade de protagonizar um vídeo. Boa parte dos 80 minutos do material bruto gravado no estúdio foi conduzida por João, que entrevistou outros internos, monitores, membros do grupo de rap, a coordenadora dos Projetos Especiais, uma jornalista do Estadão que fazia uma reportagem sobre o evento e, além disso, foi entrevistado pelo regente do coral e pela coordenadora.

Em suas questões - sempre espontâneas - os temas recorrentes eram a expectativa com a carreira artística ("você acha que vai seguir carreira?") e projetos de futuro (“o que você vai fazer quando sair daqui?"). Quando entrevistado, João insistia em afirmar seus planos, em reconhecer a prática musical - com a qual teve contato na Febem - como alavanca da mudança em sua condição e como fornecedora de perspectivas.

A familiaridade de João e de outros internos com o audiovisual lhes permitia explorar o vídeo de forma lúdica. Como João, outros jovens aproximaram-se de mim para olhar a câmera (que tinha um pequeno visor paralelo que permitia ver o que estava sendo enfocado), para pedir o microfone, para, em geral, entrevistar colegas. A linguagem utilizada nessas entrevistas era, como nas oficinas, a de telejornais, com o formato de perguntas e respostas e, em alguns casos, até com encerramento: "repórter Saturnino, para o Jornal da Tribuna", arriscou um jovem santista de uns 14 anos.

Evidentemente, a situação (gravação de um CD em um estúdio profissional) e a presença da câmera, de uma pesquisadora (eu) e de uma jornalista eram elementos propositores de uma dinâmica única, em que os jovens, antes invisíveis, tornavam-se o centro das atenções: por um dia, deixavam sua condição marginal 
para serem quase artistas, papel que alguns pareciam de fato incorporar, a despeito das parcas possibilidades de efetivação futura ${ }^{17}$.

Se, na construção do personagem "interno" (nas oficinas), os jovens trabalhavam com aspectos que compunham a identidade do grupo - e não necessariamente com elementos de sua história de vida específica -, na condição de repórter ou entrevistado no momento da gravação do $\mathrm{CD}$, cada jovem procurava ressaltar o que o diferenciava daquela condição de interno: ao fazer música, era visto de outra maneira, seu pensamento havia mudado, tinha planos de futuro.

Na construção do "interno genérico" não havia uma obrigação com a idéia de verdade: não importava como foram presos de fato, se eram reais seus planos de fuga, mas sim o fato de escolherem narrar determinados temas e idéias, que compunham um conjunto de valores relevantes para aqueles sujeitos.

Nas entrevistas concedidas aos seus próprios colegas no dia da gravação do CD, havia uma intenção de revelar-se: falar para a câmera, naquele momento, era, para alguns, uma oportunidade de visibilidade, de reconhecimento, complementar à própria condição de artista que experimentavam ao adentrar o estúdio. Para outros, a entrevista parecia ser uma oportunidade de falar de si, estimulado pela questão do outro, que, por sua vez, não era muito diferente de si. "O que você acha das drogas? Quando você sair daqui, vai voltar a usar droga?”. Entrevistador e entrevistado, nesse caso, falam do mesmo lugar, e a pergunta de um ao outro é, de fato, dirigida a si próprio.

Ao analisar o material audiovisual captado neste dia, percebo as entrevistas como um jogo de perguntas e respostas - com aspectos desafiadores, reflexivos e lúdicos. Uma característica desse jogo foi a espontaneidade, estimulada pela forma como o mesmo foi iniciado (“microfone, senhora!") e corroborada pela dinâmica como foi conduzido, na qual qualquer participante tinha acesso ao microfone, para fazer o que quisesse com o mesmo. Tal espontaneidade foi crescendo na medida em que o assunto se afastava do leitmotiv do dia (a gravação do CD, o potencial redentor da música no contexto da internação) e se aproximava das inquietações dos jovens, sobretudo dos mais jovens.

Quando João já havia realizado e concedido várias entrevistas, os meninos 
da UE 7 - de 13 a 15 anos - começaram a se entrevistar. A mudança no tom das entrevistas fica evidente no vídeo, seja em virtude da aparência dos jovens - eles parecem efetivamente crianças -, seja pelo conteúdo de sua fala. Pegavam o microfone e, rindo, inventavam ou repetiam questões que tinham ouvido. A música é identificada na fala desses jovens ao lazer, a uma quebra de rotina no cotidiano da unidade. Diferentemente de alguns dos jovens mais velhos, os menores não associam a atividade que estão realizando com qualquer perspectiva profissional. De fato, perspectiva é o que não possuem, fato que pode ser interpretado face ao dado de, nessa unidade, estarem internados, em sua maioria, jovens com pouco ou nenhum laço familiar, em geral envolvidos com consumo e tráfico de drogas, alguns já vivendo nas ruas.

O contraste entre sua expressão e corporalidade lúdicas - típicas da infância - e o conteúdo de sua fala é o conteúdo da parte final do vídeo. Um menino canta, com bons ritmo e afinação, a canção que embala o videoclipe. Aos poucos, a letra revela o universo cantado pelo garoto: o do consumo de drogas, da violência (escancarado nas onomatopéicas metralhadoras). É do mesmo garoto a declaração "eu vim aqui para falar a realidade: quero ir embora daqui, e fumar uma pedra”, geralmente recebida com risos nas platéias universitárias às quais exibi o vídeo, provavelmente pelo tom lúdico com que é pronunciada, mas, em minha opinião, um dos momentos mais perturbadores e reveladores do vídeo.

O salto do universo infantil, lúdico, ao mundo "adulto" do crime sempre me entorpeceu. Nas imagens que captei no dia da gravação do CD, meninos que brincavam com um triciclo "tico-tico" (usado por crianças de dois, três anos) me pediram para filmar com a câmera ${ }^{18}$. Deixei-a com eles por alguns minutos. Da cobertura do estúdio, onde faziam um lanche após a gravação, os meninos filmaram a casa vizinha. O conteúdo da filmagem só pude ver em casa: zooms de bumbuns e peitos das moças que estavam no quintal da casa.

De um dos poucos jovens que eu entrevistei - geralmente eu tinha um "repórter" - ouvi, de forma inquietante, uma das frases mais comuns entre os internos: “eu acho... que quando eu sair daqui minha vida vai mudar...”. As palavras foram proferidas de forma mecânica, como que decoradas depois de serem ou- 
vidas inúmeras vezes em outras entrevistas. Não tive vontade de perguntar mais. Percebia meu limite como pesquisadora, os limites do vídeo como fomentador de discursos, os limites daquele projeto de intervenção social por meio da música.

A frase, registrada pelo vídeo, ficou ecoando, no vazio...

$\mathrm{Na}$ ilha de edição - confesso que o roteiro do vídeo foi vislumbrado somente na ilha...- - percebi a sintaxe criada a partir da sobreposição de depoimentos como o daquele menino, com seus olhares ora esperançosos, ora perdidos, desesperados.

Por meio da montagem - sabiamente teorizada e praticada por Eisenstein e revisitada por Walter Benjamin - novos conceitos eram criados pela justaposição de fragmentos. A contradição e a irracionalidade - tão dificilmente expressas por meio do texto, que tende à organização, à busca do sentido - ganhavam vida em cada seqüência do vídeo.

Microfone, senhora é um dos resultados de minha pesquisa. Por seu potencial polifônico, polissêmico e interpretativo, o vídeo dialoga com o texto, fornecendo ao leitor/expectador outras possibilidades de leitura, fruição e crítica do conteúdo por mim investigado. Enquanto instrumento de pesquisa, o vídeo foi desde um caderno de campo - ao qual eu podia recorrer para ouvir de novo entrevistas, observar gestos etc. - até um propositor de situações: para o vídeo, performances eram criadas, o mundo da internação era encenado de forma ímpar. O vídeo foi também, inúmeras vezes, instrumento mediador de minha comunicação com os jovens, nem sempre fácil dada a situação de internação e as diferenças que nos separavam. Apesar de um distanciamento mínimo que nunca consegui evitar ${ }^{19}$, nas oficinas de vídeo e nas situações intermediadas pelo vídeo, conseguimos criar situações de efetiva comunicação, próximas do diálogo e da troca.

Como resultado da pesquisa, o vídeo efetivamente permite o que Jean Rouch definiu como a antropologia compartilhada ${ }^{20}$. Somente com o vídeo - que infelizmente demorei muito para editar ${ }^{21}$ - consegui apresentar a alguns informantes (e também a colegas pesquisadores) minha pesquisa. A partir da exibição, 
percebi que eles entendiam melhor meus objetivos, discutiam temas suscitados pelas imagens, se posicionavam concordando ou discordando, relembravam personagens e situações, repensavam sua própria história.

Na Febem, exibi o vídeo para as coordenadoras do hoje chamado Febem Arte, responsável pelas atividades culturais em toda a Febem/sp e para um dos membros do grupo Jigaboo, hoje oficineiro de Hip Hop no Quadrilátero do Tatuapé. A exibição - que, confesso, temi em alguns momentos, afinal estava com funcionários da instituição que é por vezes criticada no vídeo - foi acompanhada de comentários sobre o paradeiro dos meninos, sobre como eram novos naquela época, sobre a mudança no perfil do jovem hoje internado na Febem, sobre a crescente organização do crime e da violência.

Mas o ponto mais curioso da visita à Febem foi quando, ao terminar a exibição do vídeo, a coordenadora do Febem Arte foi a um armário que estava atrás de nós, e começou a procurar fitas. O armário estava repleto de material, produções da Febem Arte ou sobre seu trabalho. Me senti trocando braceletes por colares. Levei um vídeo, esperando ouvir sobre ele, sobre as representações que nele veiculei. Recebi, em troca, imagens já construídas, auto-representações orgulhosamente apresentadas. Ofereci um espelho e recebi em troca uma coleção de cartões postais (a beleza e intenção das imagens com que fui contemplada - captadas com profissionalismo, editadas com competência - aproximam-nas efetivamente do cartão postal, em oposição ao auto-retrato, que deixaria ver contradições, elipses, como as observáveis em Microfone, senhora).

Por fim, é preciso ressaltar que o vídeo, enquanto resultado da pesquisa, possibilita alguma visibilidade aos sujeitos pesquisados. Um pouco de sua condição, de seus sonhos, de suas dificuldades será visto por "leitores" da tese ou por um público mais amplo, como o de festivais de documentários, programas de TVs Educativas ${ }^{22}$, salas de aula de graduação, pós ou - tomara! - de ensino fundamental e médio, enfim, em um circuito impensável para outro tipo de produção acadêmica. Os protagonistas do vídeo são, na condição de internos, sujeitos invisiveis ${ }^{23}$. Para eles, estar à frente da câmera é uma possibilidade única de expor sua existência, seus desejos, sua revolta. Há poucas possibilidades de 
exposição: uma é a rebelião - que os faz protagonistas por meio da violência; o vídeo, tal qual proposto aqui, tem menor alcance, mas substitui a violência pela comunicação. 


\section{DAS POSSIBILIDADES DE UMA AUDIÇÃO DA VIDA SOCIAL [MÚSICA E ANTROPOLOGIA - E UM POUCO DE TEATRO, CINEMA...]}

Um etnomusicólogo percebe, em um coquetel acadêmico, que seus colegas questionam o valor musical de sons produzidos por grupos não-ocidentais. Comenta: "nossa sociedade acredita que a música é em si algo bom, e daí a crença que nós devemos gostar de seu som. Confrontados com algo cujo som eles não gostaram, meus amigos imediatamente questionaram se aquilo poderia ser música” (Nettl, 1983: 18; trad. minha).

Um músico ocidental descreve a seus interlocutores Kaluli, da Nova-Guiné, sua experiência em clubes de jazz, lembrando a atração que a música exercia sobre as jovens, que freqüentavam os locais para escutar jazz, apaixonar-se pelo músico, e, quem sabe, passar a noite com ele. Diferentemente dos acadêmicos norte-americanos do coquetel, os Kaluli perceberam na descrição do jazzman e também antropólogo branco as aproximações possíveis entre diferentes tradições musicais e consideraram a conversa um sinal de que o pesquisador havia entendido o poder da música entre eles e a importância de sua aquisição por parte dos homens do grupo (Feld, 1982: 232).

Em uma aldeia no Parque Nacional do Xingu, mulheres são o alvo das canções masculinas. Entre os Suyá, os irmãos cantam para suas irmãs porque não podem comer com elas ou abraçá-las. A uxorilocalidade - que determina que jovens do sexo masculino saiam da casa dos pais após a iniciação para viverem na casa da noiva - provoca a abominação da proximidade física entre irmãos, aproximando-a do incesto. Mas o irmão pode cantar para suas irmãs sem nem mesmo ir à sua casa. Da praça ou da periferia da aldeia, o jovem pode comunicar-se com suas irmãs. A habilidade da música em transcender a distância social, espacial e psicológica sem uma presença física que a acompanhe é descrita pelo antropólogo que estuda o grupo como uma de suas importantes características 
comunicativas (Seeger, 1980: 94).

Jovens internos da Febem transcendem, por alguns momentos, sua condição de invisibilidade, apresentando-se com orquestra e coral em salas de concerto tradicionais em São Paulo. As irmãs, mães ou namoradas que presenciam suas performances - nos teatros ou mesmo de longe, pela TV - experimentam uma aproximação de ordem diversa daquela da visita do domingo. Um tipo especial de comunicação é estabelecido por meio da música que os corpos - outrora sem liberdade - produzem.

Em comum, o etnomusicólogo, o jazzman, o pesquisador dos Suyá e eu - a pesquisadora que acompanhou os jovens aprendizes de orquestra - temos, além da antropologia, uma forma peculiar de fazê-la: ao enfatizar a prática musical como objeto da análise, adentramos os universos de significados dos grupos pela esfera da sensibilidade. Falamos, sem dúvida, sobre os Kaluli, os Suyá, o senso comum norte-americano ou o universo da internação, mas sempre a partir de sua relação com o fazer musical. Que antropologia resulta dessa abordagem ${ }^{24}$ ?

\footnotetext{
"You look, but you do not see. You touch, but you do not feel. You listen, but you do not hear. Without sight or touch [...] one can learn a great deal. But you must learn how to hear, or you will learn little about our ways."

Feiticeiro Songhay ${ }^{25}$
}

Desde o início desse capítulo, mais de uma vez pensei em falar sobre o "olhar" que aqueles antropólogos dirigem ao fazer musical dos grupos que estudam. Ato falho que revela a impregnação do caráter imagético dos discursos analíticos no campo da antropologia. A advertência do feiticeiro Songhay a um antropólogo, acima reproduzida, inspira o início de uma discussão na qual a audição deveria ter igual ou maior importância que a visão.

O fato é que as ciências sociais são fortemente vinculadas à tradição da visualidade. No Projeto Temático Alteridade, expressões culturais do mundo sensível e construções da realidade: Velhas questões, novas inquietações, Sylvia Caiuby Novaes refere-se ao léxico visual que impregna os textos das Ciências Sociais: 
"Se ao nos referirmos à sociedade utilizamos termos que traem nossa proximidade com as Ciências Naturais - falamos de organismo social, sistema, função -, quando nos referimos à nossa atitude perante a sociedade e a cultura, nosso léxico é o da visualidade. Na Antropologia falamos de observação, desde Malinowski procuramos captar o ponto de vista do nativo, tentamos reconstruir sua visão de mundo, tentamos abordar diferentes perspectivas em nossa análise, buscamos evidências empíricas para nossas observações, que façam jus a uma ótica científica. O próprio termo teoria deriva de um verbo grego que significa observar, contemplar." (Caiuby Novaes, 2002: 26/7; grifos da autora)

Tal característica das humanidades reverbera, em parte, a própria forma como a sociedade ocidental hierarquiza os sentidos. Anthony Seeger (1981) lembra que, na língua inglesa, quando alguém quer dizer que compreende algo, diz "I see” [eu vejo]. Entre nós, pessoas com idéias que só serão implementadas no futuro são chamadas "visionárias" 26 . Tal associação - entre conhecimento e visão - não se daria entre os Suyá. Na língua dessa sociedade, não faria sentido a expressão "Eu ouço, mas não compreendo", possível entre nós. Para os Suyá, uma pessoa que ouve bem também sabe, entende e atua corretamente. O barulho, para o grupo, é característico do público, do coletivo, do eufórico. Já o silêncio é associado à raiva, aos amantes e feiticeiros (idem: 67). A audição e a fala são faculdades "eminentemente sociais", enquanto a visão e o olfato, "naturais ou anti-sociais" (idem: 83). Um Suyá se torna feiticeiro porque um feitiço (waywanga) vem e vive em seus olhos, lhe conferindo uma visão extraordinária. O senso acurado de odor é atributo particularmente animal. Seeger ressalta o fato dos Suyá elaborarem com ornamentos corporais as duas faculdades que consideram sociais: grandes discos são inseridos nos lóbulos das orelhas e na parte inferior dos lábios. Já, olhos e nariz não são ornamentados (idem: 90). Analisando língua, corporalidade, vida cotidiana e música do grupo, Seeger nos mostra como os sentidos mais valorizados entre os Suyá são a audição e a fala, e não a visão, sentido, aliás, mais desenvolvido entre os feiticeiros, seres anti-sociais. 
Rafael Bastos mostra que entre os Kamayurá os verbos indicadores dos sentidos denotam também categorias de conhecimento (1978: 75-8). "Anup" corresponde a ouvir e também a compreender, enquanto "cak", a ver e também a conhecer. Os Kamayurá atribuem vantagem à "anup” sobre “cak”. Ao "nap 'yayte” (surdo) é atribuída maior deficiência que ao "e’acín” (cego).

Diferentes sociedades, diferentes razões sensoriais. Nas sociedades industriais, uma rápida enquête sobre a importância atribuída a cada um dos sentidos revela a ênfase no olhar em detrimento das demais formas de apreensão do mundo. "Respeita-se menos o ouvido do que a vista, porque ele é passivo, não laborioso, e porque a nossa sociedade industrial condena severamente a preguiça!” (Candé, 1986: 245), opina Roland de Candé, profundo conhecedor da música ocidental, em sua defesa do ouvir. "Ao pensarem sobre a surdez, quando chegam a pensar, as pessoas tendem a considerá-la menos grave que a cegueira, a vê-la como uma desvantagem, um incômodo ou uma invalidez, mas quase nunca como algo devastador num sentido radical”, lembra Oliver Sacks (1998: 22), em uma obra que dedica ao mundo dos surdos. Sacks contra-argumenta advertindo que nascer surdo é, na verdade, "infinitamente mais grave do que nascer cego", porque quem tem surdez pré-lingüística, incapaz de ouvir seus pais, pode ficar atrasado ou "permanentemente deficiente" na compreensão da língua. "E ser deficiente na linguagem, para um ser humano, é uma das calamidades mais terríveis, porque é apenas por meio da língua que estamos plenamente em nosso estado e cultura humanos...”.

David Howes (1991), em uma coletânea sobre a antropologia dos sentidos, nos convida a pensar as razões sensoriais de sociedades diversas, lembrando que há culturas que usam menos termos visuais - como a nossa - e mais o paladar, o tato, a audição ou o olfato. Cabe notar que mesmo quando pensamos em nossa própria cultura - digamos, ocidental, urbana - há campos em que podemos observar diversas razões sensoriais atuando paralelamente. Na esfera das práticas artísticas, por exemplo, visão, audição, tato - e por vezes paladar e olfato - são chamados a atuar conjuntamente na apreensão de uma obra.

No entanto, quando nos voltamos ao campo das ciências sociais, fica evi- 
dente a predominância do caráter verbal e visual dos discursos analíticos. Tiago de Oliveira Pinto (2001), ao discutir as possibilidades de uma "antropologia sonora”, ressaltou a distância que as ciências humanas e sociais mantém em relação à esfera musical:
"pensam estar analisando e falando de música, quando na verdade discorrem sobre a letra. [...] Outros pesquisadores encaram a música na sua acepção mais estreita: quando não sabem ler partitura, deixam a manifestação musical de lado por completo, como se ler partitura fosse sinônimo de entender e pré-condição para falar sobre música." (idem: 222)

Tal distanciamento reflexivo com relação à esfera musical é constitutivo das humanidades na modernidade. Dilmar Miranda (2001) lembra que a filosofia ocidental moderna evitou a música, "arte dirigida aos sentidos, ao ouvido”, diferente da poesia, cujo alvo é a "razão". Daí, a música ter ficado em último lugar na hierarquia racionalista: nos séculos 18 e 19, a música instrumental era "vista como jogo de sensações agradáveis (Kant) ou como arabesco abstrato (Rousseau), muda à razão e sem conteúdo intelectual, moral ou educativo, só tinha poder sobre nossos sentidos. Em suma, uma arte assemântica” (Miranda, 2001: 33).

Thomas Mann discorreu sobre tal ambigüidade por meio de Settembrini, personagem d'A Montanha mágica representativo desse espírito racionalista e iluminista.

\footnotetext{
“A música desperta o tempo; desperta a nós, para tirarmos do tempo um gozo mais refinado; desperta... e portanto é moral. A arte é moral na medida em que desperta. Mas que sucede, quando ela faz o contrário? Quando entorpece, adormenta, estorva a atividade e o progresso? Também disso a música é capaz; sabe perfeitamente agir como ópio. Uma influência diabólica, meus senhores. O ópio é uma obra do Diabo, porque causa apatia, estagnação, passividade, inatividade servil... Há na música um elemento perigoso, senhores. Insisto no fato da sua natureza ambígua. Não exagero ao declarar
} 
que ela é politicamente suspeita.” (Mann, 1980: 131/2)

A ambivalência do mundo musical é tematizada pelo menos desde os gregos. Estes, conscientes do confronto de forças apolíneas e dionisíacas em sua música, se protegiam do irracional receitando $\operatorname{modos}{ }^{27}$ próprios a cada situação. Para Platão, o ethos musical - definido a partir do modo usado na composição da música - era importante elemento moldador do caráter, juntamente com a ginástica e a aritmética. Para Miranda (2001: 23), a racionalização da natureza musical e de seu material sonoro foi o grande esforço de parte da vida cultural ocidental. Porém, se o intuito do ocidente era o "expurgo das pulsões dionisíacas" da matéria musical, esse nunca foi totalmente alcançado: “a música sempre manteve resíduos de irracionalidade".

Foram tais resíduos, provavelmente, que dificultaram a aproximação das ciências humanas do material musical. Prova disso são as discussões que procuraram firmar a etnomusicologia como área de conhecimento. Árdua tarefa, se levada em conta a forte herança positivista das Ciências Sociais.

Alan Merriam, um dos principais nomes da história da etnomusicologia (que se desenvolve no decorrer do século xx), sugere que a falta de atenção que os antropólogos destinaram à música deve-se, parcialmente, à necessidade de se enfatizar a "ciência" na disciplina, que prefere lidar os fatos sociais da existência humana aos culturais (Merriam, 1997: 18). Em sua argumentação, Merriam retoma a diferenciação que Cassidy (1962, apud Merriam) estabelece entre o artista e o cientista. Para este autor, o cientista diferencia-se do artista por comunicar conhecimento e não sentimentos. Merriam conclui afastando do campo do etnomusicólogo o que é subjetivo, qualitativo, discursivo, estético, e reforçando seu interesse no objetivo, quantitativo e teórico. "The ethnomusicologist is, in effect, sciencing about music" (idem: 25). Seu papel não é discutir o produto artístico em termos familiares ao humanista, mas sim procurar conhecimento e regularidades no comportamento e produto artístico. Se a "ciência” afastou os antropólogos da matéria musical, ela também engessou o etnomusicólogo, ao restringir ao mensurável e ao objetivo seu interesse no vasto campo sonoro. 


\begin{abstract}
“Eu não posso entender como alguém pode estudar sistemas estéticos sem uma preocupação com um intento estético na postura analítica ou uma preocupação em como os outros percebem as sensibilidades estéticas do próprio analista. Concentrar-se em medidas objetivas, livres de valores de preferências estéticas tem feito pouco para nos levar a uma compreensão mais informada etnograficamente ou humanamente sensível de outros sistemas visuais, musicais, poéticos e coreográficos.” (Feld, 1982: 236; trad. minha)
\end{abstract}

A reflexão de Steven Feld, de um momento já posterior da história da etnomusicologia, revela uma mudança de prumo, que poderíamos, brincando com Merriam, classificar como "arting about science”. Reflete os debates travados no interior da própria antropologia, como a crítica cultural, o ataque às etnografias clássicas, a discussão sobre o lugar do autor, mas de um ponto de vista bastante específico: a estética (subjetiva, criadora) como elemento de diálogo entre pesquisador e sujeito pesquisado.

É neste sentido que Feld - e vários outros antropólogos que estudam música, dança, teatro etc. - propõe a performance com o grupo como forma de compreensão mais profunda de suas manifestações sensíveis ${ }^{28}$ e da relação destas com o universo de sentidos dos grupos pesquisados. Feld conta que foram "as sensações físicas de vocalizar e percutir” que o aproximaram da performance estética dos Kaluli e que permitiram que alguns Kaluli se aproximassem para conversar sobre suas dimensões mais subjetivas.

Pesquisador de outra área, a antropologia da performance, Richard Schechner (1988) defende que performers de diferentes culturas têm mais facilidade de entender um ao outro - e de trocar técnicas, anedotas ou informações - do que pessoas da mesma cultura que não sejam performers. Exemplifica com a própria experiência: "fazer os movimentos do Nô, mesmo que por um breve período, me ensinou mais no meu corpo que páginas de leitura” (Schechner, 1985: 31; trad. minha). O autor lembra que o antropólogo Victor Turner extraiu desta constatação seus experimentos com a "performing ethnography”. 
Victor Turner experimentou montar com seus alunos "peças" com dramas rituais (ritos de puberdade, potlaches) ou sociais. Para tal, os alunos deveriam estudar monografias e expor falhas que percebem nestas no que tange à descrição da ação dramática. A visão do ator, criada pela performance, torna-se uma poderosa crítica de como as estruturas rituais e cerimoniais são representadas cognitivamente. A experiência tinha como objetivo ajudar os alunos a entenderem como povos de outras culturas experimentam a riqueza de sua existência social, quais as pressões morais que sofrem, que prazeres esperam receber como recompensa por seguir determinados padrões de ação, e como expressam alegria, deferência, afeição, de acordo com expectativas culturais. Schechner destaca o método como uma forma de compreensão cinética do outro.

Na etnografia que aqui apresento, minha própria experiência de aprendizado musical, seja no estudo do violoncelo - que iniciei em 1997 - ou na educação musical que experimentei desde os 05 anos de idade ao começar a aprender a tocar violão, foi fundamental para entender vários dos sentidos do aprendizado das crianças e jovens que conheci. As performances da qual participei, junto com o grupo pesquisado (infelizmente poucas) ou com outros músicos, me permitiram sentir e compartilhar sensações de forma única ${ }^{29}$.

Charles Seeger, uma das principais referências em etnomusicologia, questionou a habilidade de musicólogos em usar o discurso como meio de comunicar idéias sobre música: seus trabalhos teriam que lidar com fatores desconhecidos e imponderáveis, uma vez que eles empregam uma forma de comunicação no lugar de outra, ou seja, falam sobre música. Música e linguagem seriam formas de comunicação diferentes e isoladas, e a comunicação musical teria a peculiaridade de ser multifacetada (apud Nettl, 1983: 23).

John Blacking reforça o argumento: “como a maior parte da música é nãoverbal em concepção e execução, análises com palavras e a sintaxe do discurso podem distorcer o caráter único da música como modo de pensamento e ação” (1995: 199; trad. minha). A performance também é apresentada por Blacking como meio de cognição. A compreensão da música implicaria a combinação de dois modos de discurso: o verbal (falar sobre música com analistas e ouvintes de 
música - sendo que o analista inclui o performer, o ouvinte e o pesquisador) e o não-verbal (fazer música como modo de conhecimento, especialmente ter a experiência "bi-musical" - aprender a música de duas tradições diferentes).

Blacking insistiu também na importância dos modos de pensamento não verbais ("performativos/expressivos"), tão fundamentais e necessários à vida humana como os modos verbais e outros modos de pensamento "proposicionais/ discursivos". Seriam modos complementares mas contrastantes de pensamento, meios diversos de processar informação (Blacking, idem: 237).

\section{Uma antropologia bem temperada - contaminações musicais, cine- matográficas e teatrais}

Essa busca de uma via intermediária entre o exercício do pensamento lógico e a percepção estética devia naturalmente inspirar-se no exemplo da música, que sempre a praticou. Claude Lévi-Strauss, $O$ cru e o cozido

A questão para a antropologia seria, portanto, adentrar tais modos de pensamento expressivos, deixando-os contaminar o modo discursivo. Opções à escrita (vídeo, fotografia, montagens musicais), quando trazidas à etnografia, são enriquecedoras, mas não excluem a necessidade do texto. O desafio seria, paralelamente à incorporação de materiais sonoros ou visuais, buscar formas de impregnar o texto com esses modos outros de pensamento.

Em minha dissertação (Hikiji, 1999), discuti as possíveis relações entre linguagem cinematográfica e etnográfica. Particularmente inspiradora neste sentido é a obra Xamanismo, Colonialismo e o Homem Selvagem, de Michael Taussig (1993). O autor se apropria do conceito de montagem, de Walter Benjamin, com o objetivo de apresentar as diversas facetas do objeto em observação, privilegiando a pluralidade de vozes que o descrevem/experimentam/sentem. George Marcus, um dos principais críticos do realismo etnográfico nas etnografias clássicas, 
destaca esse trabalho de Taussig dentre as obras da chamada etnografia "experimental", e o classifica como um exemplo-chave do uso da montagem na representação alternativa de discurso, consciência e memória. Marcus (1994: 37-53) nota que a escrita etnográfica experimental caracteriza-se por forte influência da imaginação cinematográfica ${ }^{30}$. Os aspectos próprios da linguagem fílmica da simultaneidade, multiperspectivismo e descontinuidade narrativa estariam sendo praticados nessas etnografias contemporâneas, em nome da polifonia, fragmentação e reflexividade. O efeito cinematográfico de simultaneidade - a descrição de dois pontos separados no espaço em um único instante de tempo - aplicado ao texto etnográfico permitiria a problematização espacial, a representação da desterritorialização da cultura, de sua produção em vários locais diferentes ao mesmo tempo. O multiperspectivismo - a descrição de um único evento de pontos de vista radicalmente diferentes, como em Cidadão Kane (Citizen Kane, Orson Welles, 1941) - apareceria nas etnografias como sinônimo de polifonia.

Enfim, a descontinuidade narrativa - inspirada no conceito de montagem cinematográfica - provocaria o rompimento da linearidade e, conseqüentemente, a crítica cultural: "a montagem empresta técnica ao desejo de quebrar com as convenções retóricas e modos narrativos existentes, expondo sua artificialidade e arbitrariedade" (idem: 40; trad. minha).

Após o cinema, o teatro. John Dawsey (1998), também inspirado por Benjamin, propõe uma reavaliação das possibilidades de se tomar o teatro como paradigma para a Antropologia. Dawsey discute as limitações da interpretação que tem como referência o teatro dramático, de base aristotélica: nessa - cujo autor exemplar é Victor Turner - percorre-se o trajeto que vai da identificação do desvio, do momento dramático, à resolução, que é a retomada da norma, da estrutura; o encerramento do conflito por meio da catarse. Insatisfeito com este modelo para pensar situações conflituosas como as vividas pelos bóias-frias que estudara, Dawsey sugere a apropriação do teatro épico, de Bertold Brecht, como paradigma para a interpretação antropológica. Dawsey situa Brecht "na contramão" do teatro dramático. No teatro épico, há a interrupção do ilusionismo; a idéia é quebrar as redes de encantamento que envolvem espectadores e 
seus heróis. O espectador é provocado a tomar decisões. Mais que a resolução, importa a provocação, o incômodo ${ }^{31}$. As noções de interrupção da narrativa, de des-dramatização, de distanciamento do ator com relação ao papel (social) que interpreta serão a base para tal antropologia.

O conceito fundante de Clifford Geertz de "descrição densa" - a etnografia que atinge a "hierarquia estratificada de estruturas significantes em termos das quais os tiques nervosos, as piscadelas, as falsas piscadelas, as imitações, os ensaios das imitações são produzidos, percebidos e interpretados, e sem as quais eles de fato não existiriam...” (Geertz, 1989: 17) - é tingido com cores benjaminianas na releitura de Dawsey (idem: 64), tornando-o ainda mais inspirador para a etnografia que aqui se esboça. A partir do conceito de Benjamin de imagem dialética, Dawsey sugere o ato etnográfico como a busca por uma “'descrição tensa”, carregada de tensões, capaz de produzir nos próprios leitores um fechar e abrir de olhos, uma espécie de assombro diante de um cotidiano agora estranhado, um despertar”.

A contaminação da análise antropológica pela música tem em $O$ cru e o cozido um exemplo clássico. Lévi-Strauss, “o antropólogo que queria ser músico”, na definição de Wisnik (1999: 168), aproxima mito e música tonal, uma vez que a análise de ambos apresentaria "problemas de construção análogos, para os quais a música já tinha inventado soluções” (Lévi-Strauss, 1991: 23).

“Quando sugeríamos que a análise dos mitos era comparável à de uma grande
partitura, apenas tirávamos a conseqüência lógica da descoberta wagneriana
de que a estrutura dos mitos se revela por meio de uma partitura.” (idem: 24)

A música interessa a Lévi-Strauss como metáfora e forma. Curiosamente, a música que inspira sua análise não possui qualquer relação com o contexto etnográfico que forneceu o material mítico para a mesma. Lévi-Strauss tem em mente, em sua analogia, as formas musicais ocidentais como a sonata, a sinfonia, o prelúdio, a fuga, ou seja, a música de um determinado período e tradição que, 
comparável ao teatro dramático tomado como paradigma por Victor Turner ou Clifford Geertz, implica uma estrutura de apresentação, tensão e resolução, que marcará a analogia e a análise: o mito "cabe” na música tonal graças ao seu caráter "narrativo".

Mas o que fazer quando, como com os bóias-frias de Dawsey, a tensão não termina em resolução, quando a dissonância não é finalizada com o acorde dominante? Se no teatro tivemos Brecht (e a proposta de interrupção da narrativa dramática), no cinema, Sergei Eisenstein (mestre na sugestão da criação de um novo conceito a partir da justaposição de fragmentos, princípio da montagem), na música ocidental há a revolução do início do século xx. Tentemos ouvir tal música como inspiração para uma antropologia [musical] do conflito.

Fato fundante é a criação do sistema dodecafônico, por Schoenberg, em 1923. Wisnik (1999) lembra que tal sistema corresponde à antítese do sistema tonal, uma vez que rejeita seu princípio, o movimento cadencial de tensão e repouso. A música dodecafônica caracteriza-se pela construção de séries de doze sons (os doze semitons da escala cromática ${ }^{32}$ ) de forma que se retarde o maior tempo possível o retorno de um som já escutado. Assim, foge da repetição e dificulta a memorização. "Não se presta à escuta linear, melódica, temática" (Wisnik, idem: 174). Tal revolução musical afeta a composição do século como um todo. Mesmo os que não aderem diretamente ao movimento, podem se apropriar das rupturas nele efetuadas. A composição a partir de então abusará da citação, da superposição, da desconstrução.

Na metade do século, a música de vanguarda far-se-á pela inclusão definitiva do "ruído": ele explode em clusters (como pancadas no piano), glissandi (deslizamentos do tom sem subdivisão cromática), músicas aleatórias etc. A música concreta introduz o princípio da montagem no ambiente sonoro: as composições musicais são resultado da manipulação de sons gravados (ruídos, vozes, sons musicais), que são submetidos a toda espécie de manipulação: "variação de velocidade, inversão do sentido, filtragens, reverberações, misturas, montagens" (Candé, 1986: 214). Os mesmos métodos são utilizados na composição da música eletrônica, que, entretanto, parte de sons artificiais, produzidos eletronicamente. 
Uma antropologia que hoje se vislumbre musical tem material vasto para inspirar-se. Os movimentos musicais dos diversos momentos da música ocidental, as músicas de todo o mundo, o popular e o erudito, e tudo o que está no meio - os sons entre "o concerto e o desconcerto do mundo", lembrados por Wisnik - são bons para pensar a antropologia, se não como um novo paradigma (será que ainda precisamos deles?), ao menos como metáfora - por que não dizer modo, repertório, inspiração, para ficarmos no campo musical? - para a escrita etnográfica.

Entre as possibilidades de inspiração musical, estão: a inclusão do ruído na descrição etnográfica - tentativa de evidenciar o que poderia ser ocultado ou ignorado, dado que escapa ao modelo; o uso de falas dissonantes (o que não difere muito da proposta da polifonia, nas etnografias experimentais, outra metáfora musical, aliás); o evidenciamento de situações que não resultam em resolução (inversamente ao esperado da cadência tonal, e do teatro dramático...).

Na etnografia aqui desenvolvida, a escrita foi iluminada/ acompanhada pelos conceitos de interrupção da narrativa dramática (do teatro épico de Brecht), de imagem-dialética (de Benjamin), de inclusão do ruído (da música do século xx). Tal inspiração teórica é definida pelas questões colocadas pelo objeto analisado. Algumas tentativas de se refletir a prática musical entre os internos da Febem por meio do modelo dramático de Victor Turner mostraram seus limites. Se por um lado há a construção do drama (no palco das apresentações, por exemplo), por outro, em cada gesto, fala, pausa dos meninos há a interrupção e o afastamento, característicos do teatro épico. Se o palco pode ser interpretado quase sempre como exibição da igualdade ("vamos mostrar que somos gente", "eles são artistas”) o entorno, como a coxia por exemplo, configura-se como explosão da diferença, evidenciando a desigualdade. 


\section{Música e sociedade}

Música é muito mais que apenas sons capturados em um gravador. Música é
uma intenção de fazer algo chamado música (ou estruturado como o que nós
chamamos música) em oposição a outros tipos de sons. É uma habilidade de
formular séries de sons aceitos pelos membros de uma dada sociedade como
música (ou qualquer que seja a denominação que dão a isso). Música é a cons-
trução e uso de instrumentos que produzam sons. Música é a emoção que acom-
panha a produção, a apreciação e a participação em uma execução. Música é
também, é claro, os próprios sons depois de serem produzidos. É ainda intenção,
tanto quanto realização; é emoção e valor, tanto quanto estrutura e forma. Anthony Seeger, Why Suyá sing ${ }^{33}$

Em artigo histórico, publicado originalmente no periódico Ethnomusicology de 1960 (e reproduzido em Shelemay, 1992), Merriam define a etnomusicologia como um método para o estudo da música na cultura ("music in culture"). O artigo documenta a consolidação de um campo de conhecimento, a etnomusicologia: o estudo dos fazeres musicais a partir de sua íntima relação com as sociedades nas quais são desenvolvidos.

Anos mais tarde, Anthony Seeger faz sua proposta de uma "antropologia musical", tendo como referência a sugestão de Merriam de uma "antropologia da música”. Para Seeger, o foco não se limitaria ao estudo da música na cultura, tal qual sugerido por Merriam (a música como parte da vida cultural e social), mas a própria cultura poderia ser concebida como algo que acontece na música, e o objetivo do etnomusicólogo seria buscar "o modo pelo qual as performances musicais criam vários aspectos da vida cultural e social” (Seeger, 1987: XIII).

De fato, o próprio Merriam (1997 [1980]) já havia desenvolvido sua definição, afirmando que o "comportamento humano produz música, mas o processo é contínuo; o comportamento em si é moldado para produzir sons musicais, e assim o estudo de um flui para o outro" (idem: 6; trad. minha). Ou seja, Merriam já percebera que a música é produto e produtora de cultura. Na releitura de sua 
definição, já antecipava a possibilidade da inversão proposta por Seeger.

Mas, sigamos a análise de Seeger para iluminar com o exemplo etnográfico tal tese, aparentemente, comum aos autores. Em Why Suyá sing - A musical anthropology of an Amazonian people (Seeger, 1987), o autor realiza sua proposta de antropologia musical. Para Martin Stokes (1994), este trabalho é um poderoso argumento contra a divisão teórica entre o estudo da música e o estudo da sociedade. Música, para Seeger, é "todo o processo de conceitualização, realização e avaliação" da própria música (op.cit.: 65). E é por meio da performance musical que se "recria, re-estabelece, ou altera a significância do cantar e também de pessoas, tempos, espaços e audiências envolvidas”. É o canto Suyá que "expressa o status, sexo e sentimentos dos executores, e os coloca em evidência para a comunidade inteira, que os interpreta de diversas formas" (idem, ibidem). Em sua análise dos Suyá, Seeger demonstra que por meio da performance de música e dança, “aspectos fundamentais da organização social dos Suyá são reconhecidos, o tempo social é ritualmente articulado e um sistema cosmológico inteiro é compreendido" (Stokes, 1994: 2, trad. minha).

Para Oliveira Pinto, o enfoque contextual da música pela antropologia implica pensá-la não apenas do ponto de vista estético, mas como forma de comunicação:

“música raras vezes apenas é uma organização sonora no decorrer de limitado espaço de tempo. É som e movimento num sentido lato (seja este ligado à produção musical ou então à dança) e está quase sempre em estreita conexão com outras formas de cultura expressiva. Considerar este contexto amplo, quando se fala em música, é adotar um enfoque antropológico. A inserção da música nas várias atividades sociais e os significados múltiplos que decorrem desta interação, constitui importante plano de análise na antropologia da música. A relação entre som, imagem e movimento é enfocada de forma primordial neste tipo de pesquisa. Aqui música não é entendida apenas a partir de seus elementos estéticos mas, em primeiro lugar, como uma forma de comunicação que possui, semelhante a qualquer tipo de linguagem, seus pró- 
prios códigos. Música é manifestação de crenças, de identidades, é universal quanto à sua existência e importância em qualquer que seja a sociedade. Ao mesmo tempo é singular e de difícil tradução, quando apresentada fora de seu contexto ou de seu meio cultural.” (Oliveira Pinto, 2001: 222/3)

É necessário aprofundar a discussão acerca da relação entre música e sociedade. Por um lado, é consensual o fato de que, do ponto de vista da antropologia, não é possível estudar música sem se referir à cultura. No entanto, há bastante controvérsia sobre a relação entre essas esferas. Seeger (1987) atribui à música a capacidade de produzir cultura e transformar a sociedade. Para Seeger, por exemplo, "performances musicais criam vários aspectos da vida cultural e social”, sendo a música, portanto, parte da "construção e interpretação de processos sociais" (idem: xIII, trad. minha). Feld (1984) também ressalta tal interdependência entre música e vida social: para o autor, a estrutura e sentidos dos sons Kaluli são inseparáveis da fabricação da vida social e do pensamento Kaluli.

Para Geertz (1983), os trabalhos de arte - dentre os quais inclui a músi$\mathrm{Ca}^{34}$ - não definem relações sociais, não sustentam regras sociais ou fortalecem valores sociais. Apesar de afirmar que uma teoria da arte é ao mesmo tempo uma teoria da cultura - e não um empreendimento autônomo (idem: 109) -, insiste que "as anotações coloridas de Matisse e as linhas Yorubas não celebram a estrutura social. Elas materializam um modo de experimentar..." (idem: 99, trad. minha). O estudo da arte é, para o autor, o estudo de uma "sensibilidade coletiva" (idem, ibidem).

A observação da atividade musical dos jovens participantes do Projeto Guri indica a necessidade de uma abordagem intermediária, entre a de Geertz e de Seeger. Blacking é um dos autores que procura construir a ponte entre essas visões. Para o autor, a música não pode mudar a sociedade, tal qual a tecnologia ou a política, mas pode confirmar situações pré-existentes. Não gera pensamentos, mas faz as pessoas mais conscientes de sentimentos que elas experimentaram, ao reforçar, alargar ou expandir suas consciências (1974: 108). A música seria um tipo especial de ação social, não somente reflexiva, mas também geradora (1995: 
223). Música, para Blacking, é produto da ação humana e modo de pensamento gerador de ação humana (idem: 224). A relação entre música e sociedade não é direta - a música não muda a sociedade - mas “cognitiva”: o fazer musical pode ser ferramenta indispensável para a transformação da consciência, um primeiro passo para a transformação das formas sociais (idem: 232). Em diálogo com Geertz, o autor sugere que perguntemos como o grupo faz conexões entre música e outras experiências sociais. Sugere questões: como a aquisição de habilidades musicais e as experiências corporais decorrentes dessa aquisição se relacionam com outras atividades e experiências sociais? A experiência musical auxilia ou entra em conflito com outras atividades sociais? Qual o alcance da música na ampliação de consciência?

Para marcar sua posição, Blacking propõe uma inversão da análise de Geertz, que procuraria, a seu ver, contextualizar a prática artística em relação ao social. "Apesar de concordar com isso, eu também quero inverter o processo e dizer que, para um etnomusicólogo, um procedimento analítico crucial não é tanto ajustar a música ao sistema social, mas começar com um sistema musical e seus símbolos, com estilos e grupos sonoros, e então ver como e quando a sociedade se ajusta à música. Nós devemos considerar a cognição artística e a prática musical em particular como tendo papéis fundamentais na imaginação das realidades sociais" (Blacking, 1995: 234; trad. minha).

O lugar que Blacking atribui à música e a forma que propõe para abordála condiz com o tipo de problema colocado a partir da pesquisa aqui exposta. A música, tal qual vivida pelos jovens que a praticam nos projetos que analisei, é sem dúvida um "modo de experimentar" - na acepção de Geertz -, uma manifestação sensível que opera modificações no corpo e na alma de seus praticantes e ouvintes. Mas o fazer musical produz também comunicações que transcendem o palco, sala de aula ou espaço ritual, marcando relações, mexendo com valores, determinando modos de agir na imbricada teia social que envolve músicos e não-músicos. 


\section{Variações sobre um mesmo tema}

Durante esta pesquisa, os significados atribuídos ao fazer musical raramente foram afirmados com a mesma intenção e intensidade. Música podia ser ora um quebra-galho, um passatempo, ora "tudo" na vida de alguém. Do ponto de vista analítico, me foi bastante iluminadora a advertência de Anthony Seeger: a música dos indígenas das terras baixas da América do Sul nunca seria entendida enquanto fosse vista como uma forma de "arte", "atividade antes de tudo estética e além disso incidental” (Seeger, 1980: 104). Nessas sociedades, a música é parte fundamental da vida social, não somente uma de suas opções. Pensar as formas de percepção da música no segmento estudado e na sociedade envolvente seria, portanto, um primeiro passo na abordagem da relação entre música e sociedade.

Ouvi da coordenadora do Projeto Guri, Elizabeth Parro, que o objetivo do projeto não é "formar músicos", mas "mostrar para a criança uma condição de vida melhor". A ênfase do projeto está, evidentemente, nos aspectos sociais e éticos vinculados às suas atividades, não no estético. A prática musical é vista como uma forma de ocupação do tempo dos jovens e como via de acesso ao exercício da cidadania, tal qual compreendida pelos propositores da intervenção. Implícita na fala da coordenadora, está a idealização do "músico" como aquele que dominou a técnica artística, diferente de um estudante que ainda a exercita.

Mas há outra intenção por trás da afirmação de Elizabeth: evitar dar à formação musical no Guri a característica de curso "profissionalizante”, demanda comum - e restritiva - no que diz respeito às atividades oferecidas à população de baixa renda. Ensinar música sem o objetivo declarado de formar músicos - "profissionalizar" - chega a ser um desafio em um país em que a própria idéia de aprendizado musical inexiste quando se pensa nas camadas populares. A lógica que governa a educação extra-escolar para a população de baixa renda é a da utilidade: aprende-se para o trabalho. Daí a valorização dos cursos profissionalizantes em geral, como mecânica de automóveis, computação, costura etc.

Alba Zaluar, em uma pesquisa sobre projetos de prática esportiva com jovens de escolas públicas nos anos 80 , comentou a tendência de classificação 
do esporte como atividade elitista, já que associada ao lazer e ao ócio. A respeito do Guri, por exemplo, ouvi críticas que classificavam como "perda de tempo" ensinar música clássica para "moleques que deveriam estar aprendendo alguma profissão”; pedreiro, mecânico eram exemplos de ocupações úteis, que deveriam ser ensinadas no lugar da música.

Como nota Zaluar, o ócio (com o qual o lazer, o esporte e as artes são associados) é visto como exclusividade das classes abastadas, "também chamadas ociosas e cuja marca de distinção é a relação desinteressada e não utilitária com as artes, o esporte e outras atividades distanciadas do mundo do trabalho" (1994: 59). O acesso aos bens culturais e artísticos como um direito de todo cidadão é, ainda hoje, algo somente garantido no plano legal no Brasil, não no senso comum da população ${ }^{35}$.

No interior do Projeto Guri, conheci crianças e jovens que praticavam música "por diversão", como "lazer", para "matar o tempo". Mas tanto pais como parte importante dos alunos mais velhos revelavam um real interesse em se tornar [ou ver seus filhos como] "músico profissional”. Notei tal concepção quando, sempre que eu comentava que tocava violoncelo, ouvia dos jovens a pergunta: "e onde você toca?". Aos poucos, fui percebendo que para o grupo que eu pesquisava havia uma associação íntima entre prática musical e alguma esfera de atuação profissional - ou semiprofissional.

Em minha longa educação musical, dos cinco aos vinte e poucos anos, eu nunca havia pensado a música seriamente como uma possibilidade de trabalho - música era, para mim, um objeto de estudo, de diversão, de enriquecimento pessoal, de alguma sociabilidade na juventude. Foi somente após alguns anos de estudo do instrumento de orquestra, que comecei a vislumbrar a possibilidade de "tocar em algum lugar", o que implica, "ser músico", efetivamente, e até receber para tocar, eventualmente. Para os jovens participantes das orquestras do Projeto Guri, "tocar em algum lugar” é o mínimo que se espera de quem estuda música. O estudo em si não teria muito sentido sem essa meta a ser alcançada.

Em minha formação infanto-juvenil em música - em escolas e conservatórios particulares - o objetivo era "tocar bem", aprender um instrumento, mostrar 
o repertório aprendido em apresentações da escola de música, destinada aos pais e parentes mais próximos. $\mathrm{O}$ aprendizado musical fazia parte de um pacote - característico da educação burguesa - que incluía também o ensino obrigatório, as aulas de pintura, artesanato, língua estrangeira, dança e atividades esportivas.

Por que para os jovens do Guri - a maioria de baixa renda - o aprendizado musical era tão freqüentemente associado à possibilidade de inserção profissional? Vários fatores estão envolvidos em tal concepção. Há, obviamente, o fator econômico: diante do cenário de crise e desemprego no país, qualquer atividade que possa ser uma eventual fonte de renda é pensada como uma oportunidade. A música e os esportes - e ainda são - um meio de inserção profissional e mobilidade social para os negros e pobres no país ${ }^{36}$. Há também uma cultura específica do aprendizado do instrumento de orquestra, que implica, em algum momento, a participação do aprendiz em algum conjunto musical e o aproxima da efetiva possibilidade de profissionalização. O fato de muitos estudantes de instrumentos de orquestra terem músicos em suas famílias também justificaria a presença marcante da perspectiva profissional no processo de aprendizagem.

Cabe notar que a música é uma atividade que permite o trânsito entre os universos do lazer e do trabalho, por vezes misturando-os. É comum ouvirmos de músicos que seu trabalho não é reconhecido como tal. "E com o que você trabalha?" é pergunta que ouvem com freqüência, quando se apresentam como músicos. Os mesmos geralmente reconhecem que trabalhar com música é um privilégio: "trabalho com o que gosto, com o que me diverte". Questionei certa vez um jovem estudante de contrabaixo, membro de uma das orquestras do Guri, se música era para ele trabalho ou lazer. Respondeu que o erudito, que aprendia no Guri e na Escola Municipal de Música, era “obrigação, trabalho”, e o jazz - sua preferência musical - seria a união do trabalho com a diversão.

Com ou sem a perspectiva profissional, uma concepção comum entre os participantes do Guri - e diferentemente do imaginado pela coordenadora - é que o aprendizado musical (mesmo o inicial) corresponde efetivamente à experiência de se fazer música. O fato de poderem, com pouco tempo de estudo, fazer parte de um dos conjuntos musicais do Projeto (orquestras, corais ou cameratas) 
contribui ainda mais para essa autopercepção como "músico", mesmo que em formação ${ }^{37}$.

O público que assiste aos concertos dos corais e orquestras do Projeto Guri tem percepções diversas acerca das performances. Quase sempre precedidos por uma apresentação que identifica os participantes como "menores carentes", "internos na Febem”, "crianças e jovens que estão tendo uma oportunidade na vida”, os concertos não são acompanhados de forma neutra. O público sabe que não está diante de "músicos profissionais", mas de jovens que estão aprendendo música e, por isso, "tendo uma oportunidade de cidadania, de inserção social". A ênfase não é necessariamente no plano estético, mas no ético. O julgamento do espetáculo assistido levará mais em conta o fato do projeto ser algo "bom" - para os jovens, para a sociedade - do que sua capacidade de produzir o "belo".

Por outro lado, para um público leigo, a sonoridade de uma orquestra ou coral de estudantes pode não se afastar muito do que é considerado "música". Como os grupos tocam em vários locais sem tradição de apresentação com orquestras, sua música é realmente valorizada por aqueles que estão ouvindo pela primeira vez violinos tocando MPB ou Beethoven. Há ainda os casos de grandes apresentações, nas quais os grupos, após vários ensaios, tocam com músicos experientes e conhecidos, em locais nobres como a Sala São Paulo ${ }^{38}$. Nestes casos, podemos pensar que aqueles que pagam um ingresso para ouvir a cantora Fortuna, os monges do Mosteiro de São Bento e o coral do Projeto Guri ${ }^{39}$ não estão necessariamente pensando em acompanhar o resultado ético de um projeto social, mas em ouvir Música, com maiúscula mesmo.

No início deste capítulo discuti as possibilidades da exploração dos diversos sentidos no processo de construção de conhecimento antropológico. Essas possibilidades foram vislumbradas a partir de etnografias que colocaram o antropólogo diante de grupos nos quais os próprios sentidos eram hierarquizados de formas diferentes das "nossas". Autores como Anthony Seeger, Steven Feld e John Blacking apontam para possibilidades diversas de uma audição da vida social. É possível, com Seeger, pensar a organização social a partir da música e das manifestações sonoras de um grupo. Feld evidenciou a importância de ouvir com 
o grupo: o antropólogo começou a entender a cosmologia dos Kaluli, quando ouviu com eles o canto dos pássaros, e percebeu sua mimese na música, nas indumentárias, nos ritos e mitos do grupo. Blacking questionou a relação analítica que realiza a passagem direta do universo sonoro ao da escrita. Em alguns casos, seria preciso, antes de traduzir em palavras os significados da prática musical, experimentar a performance, fazer música com o grupo.

Além da diferente hierarquização dos sentidos, outros povos nos fornecem organização diversa para as dimensões estéticas e éticas, que iluminam a situação observada nesta pesquisa. O isolamento da estética dos demais domínios da vida social (ética, religião, moral, política etc.) - que predomina no ocidente moderno - não é encontrado em sociedades indígenas, por exemplo. Joanna Overing argumenta que no Ocidente, desde Kant (que remodela a filosofia moral, "purificando a ética de toda estética e de todo desejo"), tendemos a pensar a arte como uma atividade "a-social, que não pertence ao cotidiano" (Overing, 1991: 7).

Overing argumenta, como Seeger, que para compreender os povos indígenas da América do Sul não se pode pensar a estética como categoria autônoma, mas como uma categoria moral e política.

\footnotetext{
“A partir do momento em que reintegrarmos o julgamento estético ao moralmente bom e ao moralmente ruim, e ambos, julgamento e moralidade, ao conhecimento e à atividade produtivos, só então poderemos começar a dizer coisas que façam sentido acerca da economia, da organização política e da filosofia social destes povos.” (idem: 8)
}

Não tenho como objeto sociedades indígenas, mas a reflexão de Joanna Overing se aplica bem à situação aqui pesquisada. Analiso uma proposta que parte de uma atividade estética - a música - para atingir objetivos éticos, políticos e morais, como a inserção social, a cidadania, a ampliação de horizontes das crianças e jovens. O pedestal em que são colocadas as atividades artísticas - são reconhecidas, desejadas, mas isoladas, quase inalcançáveis - impede a um setor da sociedade que reconheça como arte/música o que fazem os jovens aprendizes do Guri. 
Mas para esses jovens, a música está efetivamente acontecendo: ela faz parte de suas vidas e está modificando seus corpos, seus pensamentos, seus desejos, sua percepção. Fazer música, para eles, é belo, é bom, é correto, é o presente, é uma possibilidade de futuro. 


\section{MÚSICA COMO INTER VENÇÃO SOCIAL [MÚSICA E POLÍTICA]}

A música não exprime conteúdos diretamente; ela não tem assunto... E no entanto

[...] a música mantêm com a política um vínculo operante e nem sempre visível: é que ela atua, pela própria marca do seu gesto, na vida individual e coletiva, enlaçando representações sociais a forças psíquicas...

José Miguel Wisnik

O vínculo obscuro, por vezes invisível que une a música à política - descrito por Wisnik - é o cerne das inquietações deste capítulo. Qual a alquimia que opera a transformação do universo etéreo, impalpável da música em instrumento concreto de manipulação e transformação do mundo social? Quais os possíveis traçados entre a emoção musical - experiência sensível detonada pela audição e/ou produção de sons organizados - e a constituição de sujeitos sociais? Como compreender a passagem - efetuada sem maiores esforços pelos sujeitos pesquisados - da experiência musical à social, do tocar um instrumento a perceber-se cidadão?

Esta pesquisa foi realizada junto a instituições que promovem o ensino musical ou artístico como forma de intervenção social. "O objetivo não é formar um músico, mas mudar a vida do jovem. A música como meio”, resume Nurimar Valsecchi, maestrina e coordenadora pedagógica do Projeto Guri. No discurso dos proponentes de projetos, é comum a associação entre prática musical e "recuperação de auto-estima”, "desenvolvimento de cidadania", "afastamento do perigo das ruas". Pretendo aqui levantar os elementos da sintaxe que permitem a aproximação de termos que, apesar de isolados em nossa sociedade, revelam-se muitas vezes inseparáveis: estética e ética, arte e política, prática musical e fazer social ${ }^{40}$. 
Nos últimos anos, sobretudo a partir da década de 1990, é notável o crescimento na oferta de projetos com atividades de arte-educação para grupos de crianças e jovens em comunidades de baixa renda, também denominados "em situação de risco”. Em comum, os projetos de ensino de música, teatro, dança, artes plásticas, entre outras atividades, têm a preocupação em oferecer alternativas às realidades de carência (não só financeira, mas afetiva, de lazer etc.) e de violência enfrentadas pelo público em questão (pensa-se aqui desde a violência familiar até o crime organizado, que envolve atores cada vez mais jovens). Tal apropriação da música como forma de intervenção social será pensada aqui a partir da pesquisa de campo junto ao Projeto Guri, da análise de bibliografia e do levantamento de material de divulgação ou entrevistas com proponentes de projetos com preocupações semelhantes.

Inicio a análise retomando a principal experiência governamental de ensino musical em massa para crianças e jovens no país, o projeto de Villa Lobos do canto orfeônico. Por seu ineditismo e sua dimensão, tal projeto, baseado na formação de corais que cantam principalmente hinos cívicos e temas folclóricos e populares, é uma referência aos que pesquisam a educação musical infanto-juvenil, a história e a política nacional, ou ainda aos promotores de políticas públicas que se utilizam da arte-educação.

\section{Villa Lobos e a música civilizatória}

Os anos 1930 são, provavelmente, o único momento da história do país em que o ensino musical é encarado como um projeto nacional. O Estado Novo dá total apoio ao projeto de Heitor Villa Lobos de ensino infanto-juvenil do canto orfeônico. O projeto previa curso para formação de professores especializados nesta disciplina, a criação de um orfeão artístico para cada escola, organização de discotecas e bibliotecas especializadas e a realização de grandes concentrações orfeônicas reunindo milhares de crianças e adolescentes (Contier, 1988: 252). As apresentações públicas com grandes concentrações de corais eram a marca do 
projeto. Em maio de 1931, uma concentração cívico-artística no parque Antártica, em São Paulo, reuniu 60 mil pessoas, apresentando quatro hinos (Nacional, Meu País, Brasil Novo e P'ra Frente, ó Brasil) e trechos d' O Guarani (idem: 246). Em 1935, Villa Lobos conseguiu reunir 100 mil pessoas no Rio de Janeiro.

Que características do fazer musical foram destacadas para que esse fosse tomado como uma prioridade do Estado Novo? Segundo Arnaldo Contier, que analisou em sua livre docência a relação entre música, nação e modernidade, a música era vista nos anos 30 como "arte disciplinadora por excelência" (idem: 230). Arte conciliatória, centralizadora e homogeneizante, capaz de promover a coesão nacional desejada pelo Estado Novo. Dentre as formas musicais, o destaque era o canto coral. Contier remete o leitor às palavras de Mário de Andrade:

\footnotetext{
“mas os nossos compositores deviam de insistir no coral por causa do valor 'social' que ele pode ter. País de povo desleixado onde o conceito de Pátria é quasi uma quimera a não ser pros que se aproveitam dela [...] O coro unanimisa os indivíduos." (Mário de Andrade, apud Contier, op.cit.: 231/2)
}

A inspiração para o projeto do canto orfeônico, descrita a seguir por Contier, permite ver a íntima relação entre música e política, aqui caracterizada pelo totalitarismo e pela massificação:

O projeto do canto orfeônico de Villa foi inspirado nos exemplos alemães, por ocasião de suas visitas a cidades alemãs, nos anos 20. Lá, assistiu a concentrações corais reunindo cerca de 20 mil pessoas. Com a ascensão do nazismo, tal prática se ampliou, e o forte teor nacionalista contido nessas manifestações de canto interessou a intelectuais brasileiros, como Lozano, Villa etc.(idem: 252)

O apoio de Getúlio Vargas ao projeto de Villa Lobos pode ser constatado em ações como a criação da Superintendência de Educação Musical e Artística (sEMA) e no decreto (de 1932) que determina a implantação do canto orfeônico em 
escolas em vários Estados do país. Podemos observar a consonância entre os discursos de Vargas e dos músicos aliados a Villa Lobos, sempre ressaltando valores como disciplina, trabalho, civismo e patriotismo. O potencial do ensino musical para o desenvolvimento de tais valores é destacado por Villa:

“... aplicado nas escolas tem como principal finalidade colaborar com os educadores para obter a disciplina espontânea e voluntária dos alunos, despertando, ao mesmo tempo na mocidade, um sadio interesse pelas artes em geral... [...] O objetivo que temos em vista [...] é permitir que as novas gerações se formem dentro dos bons sentimentos estéticos e cívicos e que a nossa pátria, como sucede à nacionalidade vigorosa, possa ter uma arte digna da grandeza do seu povo.” (Villa Lobos, in Contier: 282)

Wisnik aproxima tal ímpeto pedagógico dos ideais da catequese, e conta que Anchieta é uma obsessão de Villa Lobos. ${ }^{41} \mathrm{O}$ autor lembra que é recorrente no discurso de Villa a comparação entre povo, crianças e índios, carentes de serem “catequizados pela 'cultura' para se converterem, de massa inculta e desordenada, em povo adulto, ordeiro e civilizado" (Squeff \& Wisnik, 1982: 186).

Completa o ideário do projeto músico-civilizatório da associação Villa Lobos - Estado Novo o anti-individualismo, marcado pela valorização de um coletivo quase sagrado (no qual Vargas é “o” orador/sacerdote e a Pátria o objeto da louvação), que absorve o indivíduo, agora parte de um Todo.

\footnotetext{
“O canto coletivo representava uma arma contra o egoísmo e o individualismo reinantes no Brasil, durante a Velha República. Era imprescindível agora integrar o indivíduo à coletividade. [...] Segundo Villa, o teatro ou o estádio de futebol transfigurava-se num templo, ou local sagrado, onde o indivíduo se confundia com o coletivo, ouvindo, em silêncio, os discursos proferidos pelo Chefe (Vargas) ou as músicas em louvor à Pátria.” (Contier: 262/3)
}

Mário de Andrade, em uma sugestão de discurso, provavelmente encaminhada 
ao Ministro da Educação Gustavo Capanema, completa a aproximação entre música e coletividade, deixando ver também sua associação ao universo do trabalho, da guerra e da política:

\begin{abstract}
"A música é universalmente conhecida como a coletivizadora-mor entre as artes. Só o teatro se lhe aproxima como função pragmática. É uma questão especialmente de ritmo, mas este por si não tem tamanho poder como quando auxiliado pelo som das melodias. A maior prova deste poder coletivizador e cívico da música está em que, dentre todas as artes, ela é a única que se imiscui no trabalho. Em todas as partes do mundo canta-se durante o trabalho, canções de remar, de colheita, de fiar etc., etc. É também a música que entra nos trabalhos militares da guerra. Pelo menos até este se tornar mecânico. Os hinários de religião, política, de civismo." Plano de Mário de Andrade (manuscrito, sem assinatura, s.d., apud Schwartzman et alli, 2000)
\end{abstract}

\title{
reverberações
}

Os 70 anos que nos separam do projeto de educação cívico-musical de Villa Lobos evidenciam suas peculiaridades ideológicas, mas não nos deixam ver aspectos como a recepção e a ressignificação do canto orfeônico junto às milhares de crianças e adolescentes que puderam praticá-lo, ou mesmo analisar, do ponto de vista da performance, as apresentações mobilizadoras descritas por alguns autores somente em sua grandeza numérica.

Mesmo assim, é possível identificar coincidências e diferenças nos discursos dos músicos e políticos do Estado Novo e dos dias atuais. Na análise dos discursos, por exemplo, encontramos noções recorrentes, como a valorização da coletividade. No entanto, uma análise semântica aponta para sentidos diversos desse termo. O coletivo valorizado no projeto de Villa Lobos é associado à disciplina, à obediência, à união em torno de um único ideal, ao patriotismo.

Nos projetos atuais, ao coletivo são associadas as idéias de sociabilidade, cidadania, consciência de direitos, crítica, protagonismo. Alguns dos depoimentos 
abaixo reproduzidos foram coletados em minha pesquisa de campo. Outros são fruto de pesquisa promovida pela Unesco - Organização das Nações Unidas para a Educação, Ciência e Cultura (Castro, 2001), na qual são analisadas 30 iniciativas de diferentes estados do país, em que projetos em arte, cultura, cidadania ou esporte são apontados como alternativas à realidade de pobreza e violência dos jovens atendidos. Nas falas de proponentes e coordenadores evidencia-se a ênfase no desenvolvimento da relação entre o indivíduo e uma coletividade, com vistas à autonomia pessoal e à ampliação de horizontes ${ }^{42}$.

“A gente acredita que o contato com a arte, com o sensível vai fazer a ponte entre o que cada um tem dentro de si com o social. Se pelo trabalho de arte a criança pode entender e expressar o mundo, cada um de sua maneira, isso contribui para que eles tenham ferramentas para poder compreender o mundo de forma autônoma, tenham autonomia de ação. O trabalho assistencial em situações de emergência é importante também. Suprir de informações (história, português, matemática) é importante. Mas sem o pano de fundo da arte, de ter uma visão mais ampla do mundo, nenhuma das outras coisas tem sentido. Por isso, a arte como pano de fundo que norteia nosso trabalho.”

Maria Corina Gama de Macedo - coordenadora da Casa do Zezinho, São Paulo/sp 43

“O objetivo do projeto não é formar músicos, mas sim trabalhar auto-estima, cidadania, tirar a criança da rua e mostrar para ela uma condição de vida melhor.” Elizabeth Parro - coordenadora geral do Projeto Guri, São Paulo/sP

"[A arte] abre a mente para uma visão de mundo. Porque o que acontece muito, especialmente aqui no bairro, é que os jovens só conhecem esse mundo e a reflexão que fazemos é em cima disso, pois essa é a referência que eles têm. É o bairro, é a violência. [...] Claro que o objetivo maior é que eles cantem, mas tem toda uma história: o respeito, o ouvir o outro, a atenção, a questão de se saber o momento de começar e de parar. [...] A arte dá uma visão de mundo 
e de limite e estimula uma consciência individual - sua possibilidade de viver a beleza, admirar-se com sons e cores - e uma consciência coletiva."

Coordenação do Liceu de Artes e Ofícios, Salvador/BA (in Castro, 2001: 510)

"A idéia não era formar heróis, estrelas. Sabemos que as crianças de periferia só conseguem subir quando viram heróis: ou um grande cantor, ou um grande jogador de futebol. A idéia era não privilegiar a conquista individual, mas dar uma oportunidade para que socialmente houvesse uma atividade que favorecesse a integração e a inclusão. [...] A música, diferentemente de outras atividades, é uma atividade de conjunto. Tem que fazer junto - o coral, a orquestra - apesar de ter solos, é uma atividade de conjunto. Para a idéia de integração, disciplina, organização... é a maneira mais adequada para criar a sensação de trabalho em conjunto. Queríamos uma atividade que todos pudessem fazer, não tivesse só estrelas. Como no futebol, você pode ter um jogador que joga melhor, mas você só pode fazer se você tem um time que joga junto. E a música é uma atividade que permite esse fazer junto de uma maneira linda."

Melanie Farkas - Presidente da Sociedade dos Amigos do Projeto Guri

Nos projetos recentes, o coletivo é, geralmente, valorizado como locus de sociabilização, em oposição ao isolamento que tornaria os jovens mais vulneráveis. $\mathrm{Na}$ análise dos autores da pesquisa da Unesco, já citada, as experiências estudadas investem "no resgate da auto-estima, incentivando o jovem para que se sinta sujeito coletivo, que se queira como pessoa, que seja admirado entre amigos e comunidades não por inspirar medo, pelo poder de uma arma, mas pelo poder de produzir prazeres, porque é um artista, um empreendedor, um produtor e consumidor do belo e da arte” (Castro, 2001: 518/9). A própria noção de autoestima, mais comumente associada à esfera individual, também é pensada em relação à coletividade: "Aliado à arte, especificamente à estética, o conceito de auto-estima pode ser trabalhado não somente em processos individualizados, 
com cada jovem em particular, mas também em ação coletiva. Tais vetores seriam parte de uma trajetória interligando o individual e o coletivo, ou seja, um em decorrência do outro. O indivíduo produz, mas a auto-estima resulta do reconhecimento coletivo de sua produção artístico-cultural ou do prazer de ser um conhecedor do assunto, um consumidor de arte e cultura" (idem: 489).

O projeto do canto orfeônico se estendeu por mais de uma década e deixou marcas na educação musical infanto-juvenil no Brasil. Até a década de 70, quando a ditadura extinguiu a educação musical do currículo obrigatório escolar, usava-se material para coral produzido por Villa Lobos nas aulas de música das escolas públicas e privadas.

Na proposta do Guri, não há referências explícitas ao projeto de Villa Lobos. O canto orfeônico não foi um modelo observado quando da elaboração do que seria o ensino de canto e instrumentos de orquestra. No entanto, alguns conceitos sobre a relação entre música e comportamento, em voga nos anos 30, parecem persistir no ideário dos proponentes dos projetos desenvolvidos nos últimos anos.

A noção de disciplina - valorizada como meta a ser alcançada a partir do fazer artístico - é uma dentre as que remetem a um ideal de projeto civilizatório, que ecoa Villa Lobos e o ideal aristotélico de relação entre educação musical e educação moral. Nas falas de coordenadores, professores e mesmo alunos do Projeto Guri a formação de orquestra e o ensino da prática orquestral são sempre associados à idéia de disciplina. É preciso “ficar de olho no maestro", respeitar suas instruções, bem como aprender a ouvir o colega, saber esperar etc. Que a disciplina seja um elemento importante no estudo musical, não há dúvida. Bruno Nettl (1983), importante pesquisador de formas de aprendizado musical em diversas culturas, comenta que o conceito de disciplina é fundamental à música ocidental (assim como à indiana): o músico deve praticar várias horas por dia, dirigindo seu esforço para o que irá acontecer em uma performance. O que chama a atenção aqui - na análise dos projetos atuais - é a supervalorização da disciplina dentre tantos outros atributos necessários ao fazer musical.

Também a importância atribuída a uma formação musical "erudita" por 
parte da coordenação do Projeto Guri, precisa ser pensada em seu caráter ideológico. A coordenação do Guri o descreve como um projeto de ensino de música de orquestra - "principalmente erudita" - para jovens predominantemente de baixa renda, que têm "pouco acesso à cultura" ${ }^{44}$. Há, nessas definições, um óbvio preconceito que opõe o erudito ao popular, supervalorizando o primeiro, e que ignora o conhecimento prévio dos jovens.

A prática do projeto se contrapõe ao discurso do proponente ${ }^{45}$. No cotidiano dos pólos, há brechas e reapropriações do dito “erudito”. Para vários dos alunos, por exemplo, a “cultura erudita” era já conhecida, mas com outro nome: música de culto. A melodia da "Ode à Alegria" de Beethoven, por exemplo, é familiar a muitos dos jovens, que a ouvem na igreja em forma de hino religioso. Para outros, a técnica erudita aprendida em aulas de canto ou violão tem um caráter de formação, de aquisição de conhecimentos que poderão aplicar na prática musical de sua predileção. A regente Regina Kinjo aponta a vantagem do trânsito entre estilos: "É um ensinamento erudito que a gente dá. Dou técnica vocal erudita para depois passar para o popular. Porque eles vão ter muito mais voz para tudo".

O maestro João Maurício Galindo, um dos responsáveis pelo desenvolvimento do método para ensino de cordas no Guri, apresenta de modo bem diverso o objetivo do Projeto. Questionado sobre o porquê do ensino "erudito" para uma população jovem de baixa renda, o maestro me respondeu: "Nós não propusemos música erudita, nós propusemos fazer música em conjunto”. Galindo também lembra que é um estereótipo associar música de orquestra à música de elite. Regente de várias orquestras, jovens e profissionais, Galindo observa que a maioria dos músicos em São Paulo não vem de famílias de alto poder aquisitivo, mas sim de classe média ou baixa. A Orquestra Juvenil do Estado de São Paulo, dirigida por Galindo desde 1990, é um exemplo. A maioria dos jovens é de famílias de baixa renda e vem de distantes bairros da periferia da capital, segundo o maestro.

Outro dado: boa parte dos músicos das orquestras profissionais e amadoras de São Paulo começou a aprender música nas igrejas evangélicas que mantêm 
uma orquestra para tocar nos cultos e oferecem aulas de instrumentos para os fiéis. O depoimento confirma a observação que fiz nos pólos abertos (a Febem é uma exceção), e alerta para o fato de que a formação orquestral não é completamente estranha à população de baixa renda, mas é, ao contrário, uma das possibilidades musicais da periferia paulista.

Galindo lembra ainda que o repertório tocado pelas orquestras de alunos do Projeto Guri tem desde arranjos simplificados de clássicos do repertório erudito até melodias de canções folclóricas, populares, temas de filmes etc. "Eles acabam conhecendo a música popular brasileira no Projeto, porque a referência de boa parte dos jovens não é mais MPB, mas pagode, sertanejo", adverte o maestro. Galindo é atualmente regente da Orquestra Jazz Sinfônica, uma das únicas da América Latina que toca MPв com arranjos orquestrais.

De outro maestro, Valter Batista de Azevedo, “Asa”, regente da orquestra do pólo Mazzaropi, ouvi que um dos objetivos iniciais do projeto - ao menos por parte dele e da maestrina Nurimar Valsecchi - era formar orquestras no formato da Jazz Sinfônica, ou seja, com repertório popular: "acho uma idéia sensacional: tocar música popular com cara meio erudita, porque tem cordas, tem instrumentino, uma outra roupagem, como a jazz sinfônica profissional”. Asa, ele próprio músico e arranjador voltado à música popular, desenvolve no pólo Mazzaropi um repertório misto, com bastante ênfase na мРв. Portanto, no Mazzaropi e em outros pólos, as orquestras de estudantes têm em seu repertório desde arranjos simplificados de clássicos do repertório erudito até melodias de canções folclóricas, temas populares, trilhas de filmes etc.

Cabe notar, por fim, que embora valores como disciplina e "cultura para quem não tem” ainda estejam em pauta em projetos como o Guri, agora não são mais o centro desses projetos. Alba Zaluar (1994), em uma análise de programas esportivos oferecidos a comunidades de baixa renda na década de 80, também toma como referência comparativa a prática esportiva durante o Estado Novo. Segundo a autora, neste período o programa esportivo era imbuído de uma perspectiva "unificadora, higienista e cívica" (o que coincidiria com o programa musical de Villa Lobos, se considerarmos as análises de Wisnik e Contier). Já nos 
anos 70 e 80, programas esportivos como o Priesp, da Fundação Roberto Marinho, enfatizariam não a disciplina, mas a sociabilidade e o lúdico. Com relação aos projetos aqui pensados, principalmente o Guri, também é possível afirmar uma mudança de perspectiva com relação a valores e objetivos. Se, por um lado, disciplina e saberes hierarquizados continuam valorizados nesses projetos, surgem novas pautas como cidadania, auto-estima e inclusão social.

\section{A arte como instrumento de intervenção social}

O volume da oferta de projetos de arte-educação para comunidades de jovens de baixa renda é um indicador de quanto a arte vem sendo reconhecida como elemento fundamental de intervenção social na atual agenda relativa à infância e juventude no país. Uma análise das propostas desses projetos revela os novos sentidos agregados ao fazer artístico quando este é parte de um projeto de intervenção social.

A Agência de Notícias dos Direitos da Infância (ANDI) dispõe em seu site (www.andi.org.br) de um "Banco de projetos sociais" que é dividido em áreas de atuação. Na área “Arte e Cultura” são apresentados cerca de 200 projetos de organizações da sociedade civil, provenientes de todo o país, com foco em atividades relacionadas à arte-educação destinadas a comunidades de baixa renda, sobretudo crianças e jovens. No mesmo site, são listadas mais de 30 entidades governamentais e mais de 40 empresas, fundações ou institutos que também mantêm projetos com atividades artísticas direcionadas a públicos com algum nível de carência.

A leitura das apresentações desses projetos revela muitas recorrências. O público-alvo é constantemente definido como "jovens em situação de risco” (ou por variantes: "risco social ou pessoal”, "jovens carentes", “comunidades menos favorecidas", "população excluída"). Nos objetivos, destacam-se as possibilidades de, por meio da arte, se promover cidadania, integração social, sociabilização, desenvolvimento da auto-estima, além de "tirar as crianças das ruas" e "ampliar 
o universo cultural".

As autoras da pesquisa já citada da Unesco também identificam nas falas dos proponentes e participantes dos projetos (em arte, cultura, cidadania ou esporte) "peças de linguagem recorrentes", que organizaram em um "vocabulário de sentidos" ${ }^{46}$. Entre os termos analisados, estão "protagonismo juvenil”, "auto-estima”, "pertencer”, "identidade”, “cidadania”. As coincidências entre tal seleção semântica e as recorrências já observadas no discurso do Projeto Guri e dos demais com os quais tive algum contato apontam para a centralidade desses termos e a necessidade de sua desconstrução analítica.

\section{o risco}

A primeira expressão recorrente nos programas dos projetos enfocados é "infância e adolescência em situação de risco". Tal sentença descreve um amplo público, formado geralmente por crianças e jovens de baixa renda, com acesso limitado às redes de saúde, educação e lazer e, por vezes, com vínculos familiares parcial ou totalmente rompidos.

O uso constante da expressão - "situação de risco" - pode esmaecer seu sentido primeiro. "Perigo ou possibilidade de perigo", define o Aurélio. Ou seja, ao se afirmar a situação de risco, se está falando do perigo de ser criança e jovem, sobretudo de baixa renda, no Brasil. Outros sentidos são agregados quando se pensa uma exegese do risco por meio de expressões do senso comum. "Corda bamba", "meio-fio", "se correr o bicho pega, se ficar o bicho come", "sem saída". O trânsito se dá entre o incerto, o ambíguo, o liminar - em risco - e a falta de opções. A única certeza é a iminência do perigo: o risco do envolvimento com o crime, com o tráfico de drogas, com a violência em suas diversas manifestações.

Nas falas dos diversos atores pesquisados, quase em uníssono, é destacado o risco da "rua". A rua da metrópole é associada à crescente criminalidade, que envolve cada vez pessoas mais jovens. No espaço urbano, as formas de sociabilidade passam por mudanças radicais. A rua - outrora espaço da brincadeira, do encontro, dos vizinhos - é associada agora ao perigo. Deve-se evitar "deixar as 
crianças na rua”. O tempo ocioso, outrora sinal diacrítico da infância - que tem o tempo do estudo e da brincadeira, que é lembrada nostalgicamente pelo adulto “que não tem tempo para nada” -, é visto agora como "tempo perigoso": quando não se tem o que fazer, "se aprende besteira", "fica-se sujeito às más influências da rua”. O tempo livre, antes tão valorizado, é agora tempo a ser ocupado ${ }^{47}$.

A difusão da expressão "situação de risco" parece ser contemporânea ao processo de formulação, aprovação e discussão do Estatuto da Criança e do Adolescente (ECA, lei federal no. 8069, aprovada e publicada em 13 de julho de 1990). O ECA surge em um contexto de ampla discussão dos direitos da criança e do adolescente e, no caso brasileiro, de discussões para a elaboração da Constituinte. Esta é considerada um marco com relação à doutrina de proteção da infanto-adolescência no país. Na Constituição (art. 227), a "proteção integral” da criança e do adolescente passa a ser responsabilidade da "família, da sociedade e do Estado", que devem "assegurar à criança e ao adolescente, com absoluta prioridade, o direito à vida, à saúde, à alimentação, à educação, ao lazer, à profissionalização, à cultura, à dignidade, ao respeito, à liberdade e à convivência familiar e comunitária”.

O ECA regulamenta tal doutrina de "proteção integral”. Diferentemente do Código de Menores (lei 6.697, de 10 de outubro de 1979) - que legislava sobre a situação do "menor" até então, prevendo somente a proteção e vigilância a menores "em situação irregular" - o ECA prevê a "proteção integral” à criança e ao adolescente, independentemente de condição social ou jurídica. Com o ECA, a criança e o adolescente ficam caracterizados como sujeitos de direito ${ }^{48}$, e a sociedade como um todo é comprometida com a observação ao respeito aos direitos individuais e sociais destas "pessoas em desenvolvimento".

A "situação de risco" pode ser pensada, tendo o ECA como base, como um conjunto de fatores que impediriam o exercício dos direitos em questão, do direito à vida até os direitos ao lazer, ao respeito, à liberdade ${ }^{49}$. Nos discursos dos proponentes de projetos com quem conversei ${ }^{50}$, o risco é, geralmente associado à desestruturação familiar (ausência de pai ou mãe - geralmente, pai), à violência familiar, ao desemprego, ao acesso ao universo do crime (e sua configuração 
como opção ao trabalho), ao acesso às drogas e ao tráfico, sendo o risco associado à violência a principal preocupação de proponentes e pais ${ }^{51}$.

Tal preocupação não é infundada. No Brasil - e no mundo - observa-se nos últimos anos o crescimento dos índices de criminalidade e das taxas de homicídio contra adolescentes, sobretudo jovens entre 15 e 24 anos, do sexo masculino, morador das periferias metropolitanas ${ }^{52}$. Paula Miraglia (2002) nota que em 2000, a taxa de óbitos por homicídio para a população total no Brasil foi de 27,0 por 100 mil habitantes ${ }^{53}$, enquanto em São Paulo esse número sobe para 42,2. Já na faixa etária 15-24 anos, no mesmo ano, a taxa no Brasil é de 52,1 e em São Paulo é de 89,6, número inferior somente aos estados do Rio de Janeiro $(107,6)$ e Pernambuco $(102,8)$.

Miraglia (idem) destaca ainda a identificação, em pesquisa promovida pelo Governo do Estado de São Paulo, de "bolsões de risco", ou "bolsões da violência" em bairros da capital paulista, dentre os quais figuram os que mais enviavam adolescentes para a Febem. Em distritos como Cidade Ademar, Sapobempa, Jabaquara, Itaquera e Jardim Ângela, a taxa de homicídios entre jovens de 15 a 24 anos chegou a atingir 206,87 em $1999^{54}$.

Em 2002, a Fundação SEAdE lançou o Índice de Vulnerabilidade Juvenil (IVJ), coordenado pela socióloga Felícia Madeira ${ }^{55}$. O indicador elegeu seis variáveis para identificar regiões metropolitanas nas quais há um risco maior de que os jovens (entre 15 a 19 anos) se envolvam com a criminalidade. Essas variáveis são: a taxa de crescimento populacional, o número de jovens (entre 15 a 19 anos) residentes no local, a taxa de mortalidade por homicídio nessa faixa etária, o percentual de mães adolescentes grávidas, o valor do rendimento do chefe de família e os jovens fora da escola.

O Ivj é visto com reservas por alguns pesquisadores, uma vez que elege os termos do que seria uma condição de vulnerabilidade. "O mais grave, entretanto, é que, ao afirmar que existe um grau de vulnerabilidade ao qual os jovens estão suscetíveis, e que esse grau indica uma chance maior de envolvimento com a criminalidade, o IV j não só estigmatiza, como também cristaliza uma condição. É como se o meio social que atinge um determinado grau de periferização, con- 
denasse seus jovens ao mundo do crime. Nesse contexto de pobreza, engravidar precocemente, por exemplo, adquire um valor de risco tão importante quanto morrer assassinado" (Miraglia, idem: 8).

A observação serve para advertir para o risco interpretativo e político de se vincular a criminalidade juvenil urbana com a exclusão social. Vários autores têm discutido o problema da aproximação entre violência, juventude e pobreza. Fernando Londoño mostra que, até o século xix, a expressão "menor" era usada para "assinalar os limites etários, que impediam as pessoas de ter direito à emancipação paterna ou assumir responsabilidades civis ou canônicas”. Somente no fim do XIX os juristas brasileiros 'descobrem o 'menor' nas crianças e adolescentes pobres das cidades [...]. Eram, pois, menores abandonados as crianças que povoavam as ruas do centro das cidades, os mercados, as praças e que por incorrer em delitos freqüentavam o xadrez e a cadeia, neste caso passando a serem chamadas de menores criminosos" (Londoño, 1996: 135). Rosa Maria Ferreira (1979), em uma pesquisa pioneira realizada com meninos de rua, mostrou a associação freqüente dos conceitos de abandono e delinqüência, e afirmou a necessidade de questionar o conceito de "menor", bem como a vinculação entre pobreza, abandono familiar e "desvio de conduta". Emir Sader (1987) mostra como a "questão do menor", vista na década de 60 como "problema de miséria social”, passa a ser encarada, nos anos 80 , como "problema de segurança pública" (idem: 14-5). A leitura diacrônica da expressão revela a origem da sua associação à criminalidade, que aos poucos substitui o sentido inicial de mera classificação etária. Aqui, evidencia-se o aspecto mais perverso da situação de risco: quando a questão do menor se vê transformada em "problema de segurança pública”, evidencia-se que quem se vê em risco é a própria sociedade; os jovens são os protagonistas da violência, não sua vítima.

A associação entre pobreza e criminalidade é uma representação já suficientemente enraizada no imaginário do país. Há uma "super-representação dos pobres nas estatísticas ilegais ou criminosas" (Paixão, 1983, apud Zaluar, 1994b: 60). Sabe-se que "como medida preventiva mais utilizada até hoje, continuam sendo presos para averiguação [...]: os jovens, os pretos, os pobremente 
vestidos." (Zaluar, idem: 64). Como lembra Vera Telles (1992: 43), “a pobreza é transfigurada em questão de segurança pública nas imagens ameaçadoras da convulsão social e da criminalidade urbana que reclama a ação punitiva e repressiva do Estado".

Esses e outros autores têm questionado a associação entre violência e pobreza, apontando a violência e a criminalidade como fenômenos de causas múltiplas. Teresa Caldeira (2000), por exemplo, afirma a necessidade de relacionar o aumento da violência ao contexto sócio-cultural que apóia o uso da violência como forma de punição e repressão ao crime, às concepções do corpo que legitimam intervenções violentas, à descrença no judiciário e sua capacidade de mediar conflitos, entre outros.

A categoria "situação de risco" deve ser situada nesse caleidoscópio de informações e representações acerca da situação da infância e juventude no Brasil, país de inúmeras desigualdades sociais. Penso que a formulação da categoria, a priori, não estigmatiza nenhum grupo social específico. A carência material é apenas um dos fatores associados ao "risco". Como já afirmado, outros fatores como desagregação e/ou violência familiar, desemprego, o crime organizado, as drogas e o tráfico, a ausência de opções de lazer etc. são igualmente elencados como potenciais elementos de "risco" para as crianças e jovens.

Para entender os sentidos da sugestão do fazer artístico como oposição à situação de risco é preciso pensar nos outros termos associados a este fazer nos discursos dos proponentes e participantes de projetos de intervenção social. Na apresentação dos diversos projetos em arte-educação para populações de baixa renda, afirma-se que a arte "reduz" o risco, ao promover cidadania, integração social, sociabilidade, auto-estima. Adentremos alguns desses termos.

\section{auto-estima}

Lidar com a auto-estima de crianças e jovens de baixa renda é considerado pela maioria dos proponentes um dos grandes desafios dos projetos ${ }^{56}$. A arte é apontada por coordenadores e por especialistas na questão da infanto-adolescência 
em situação de risco como um dos principais instrumentos para superar este desafio. Cabe notar, desde já, que, a noção de auto-estima não é um conceito amplamente discutido e definido de forma única. Da mesma forma que termos como "cidadania” e "sociabilidade", "auto-estima” é parte do "vocabulário de sentidos" elencado por Mary Garcia Castro (2001): é enfatizada na maioria dos projetos de arte-educação, mas, "à custa de tanto se repetir", faz-se muitas vezes um termo esvaziado ou ambíguo (idem: 482).

No projeto Casa do Zezinho, a arte é valorizada por seu potencial reflexivo. A coordenação acredita que as atividades em arte-educação que são desenvolvidas no projeto "despertam sensibilidades, criatividade", possibilitam "autonomia de pensamento e de criação". Por isso, segundo a coordenação, seria possível aumentar a auto-estima do grupo. Auto-estima, aqui, é pensada como “sentir-se competente", "se gostar", "se valorizar". É trabalhada por meio da apresentação do belo e dos cuidados com o corpo (tanto em termos médicos, como estéticos).

"Entendemos a arte-educação como instrumento de organização do indivíduo. Pensamos que, explorando os cinco sentidos, estamos ajudando o crescimento. O objetivo é fazer com que as crianças cresçam, sintam que são capazes e competentes naquilo que fazem."

Inaiá Feliz Pereira, coordenadora pedagógica da Casa do Zezinho, sP

"As crianças moram em situação de favela, perto de córrego, muitas vezes sem banheiro dentro de casa, não tem condições de se vestir adequadamente. Têm poucas condições materiais e pouca atenção e carinho na família. Isso faz com que a violência aumente. Falta cuidado: tanto o cuidado físico, pessoal, como o cuidado afetivo das famílias com as crianças. São crianças agressivas, até para se defender de um mundo que é hostil para elas. A auto-estima, o se gostar, o se valorizar é muito baixo. São crianças que na escola tem aula com 40, 50 alunos. Como o professor pode prestar atenção em cada um? As crianças são, o tempo inteiro, desrespeitadas, desconsideradas, então acabam se considerando mesmo 
uma sucata da sociedade. O trabalho que fazemos aqui acaba interferindo até na maneira da família lidar com os filhos. Temos a preocupação com a beleza, com a harmonia, com as cores, o cuidado com a aparência, com a saúde, com os problemas de pele, com o cabelo cortado. E a valorização da expressão, do saber de cada um. Isso faz com que a auto-estima - o se gostar, se respeitar, se colocar como indivíduo no mundo - cresça muito. Cada um passa a ter uma segurança naquilo que faz.”

Maria Corina Gama de Macedo, coordenadora da Casa do Zezinho, sP

Na fala de Corina surge, além da questão da auto-estima, a associação entre violência e pobreza. Quando a coordenadora diz: "isso faz com que a violência aumente", está se referindo à escassez de recursos materiais e "carinho na família”. Não é meu intuito desconstruir sua fala, mesmo porque é, no limite, uma conversa, nos quais os termos se sobrepõem, sem uma preocupação muito grande com sua organização. Mas é interessante pensar que as condições descritas por Corina - a ausência de banheiro, a superlotação das salas de aula, a falta de recursos - são, em si, uma violência contra essas crianças. Prefiro inverter a sintaxe da frase. "Isso" - a desigualdade social, a ausência de condições mínimas de moradia, saúde, educação etc. - não faz com que a violência aumente, mas é uma violência.

No Projeto Guri - o mais profundamente estudado nesta pesquisa - a possibilidade da apresentação pública do aprendizado artístico (musical, no caso), geralmente em um teatro ou auditório próprio para a prática musical ${ }^{57}$, é vista como o principal instrumento para trabalhar a auto-estima dos participantes. “Auto-estima” é associada ao "prazer" de ser visto, a sentir-se importante, à “autoconfiança”.

"Pelo que a gente tem visto no Guri, todo ser humano tem uma necessidade muito grande de se projetar. Com a vida que nós temos hoje, de televisão, mídia, a criança sonha muito em querer ser alguém um dia. Esse resgate da auto-estima está funcionando muito em cima das apresentações que a gente proporciona e dos espaços que estão sendo criados para que essa criança possa se mostrar. Como no 
ano passado: juntar uma orquestra de mais de 150 componentes aqui na Sala São Paulo... Foi uma apresentação enorme, com a Celine Imbert, na música erudita, e o Toquinho, na música popular. O que a gente vê de auto-estima nisso? O prazer que eles tiveram...”

Ângela Maria Visconti, supervisora técnica do Projeto Guri

“Em 1996, levamos [para o Festival de Inverno de Campos do Jordão] a orquestra dos meninos, dos menores infratores, mais o coral dos meninos e fizemos um espetáculo com o Toquinho. Foi lindo, e tivemos uma prova de quanto a música transformava o ser humano. Que transforma, nós sabemos, todos adoramos música, mexe com a emoção. Mas quanto mexe com a auto-estima, cidadania, o quanto eles se sentiram importantes estando no palco e representando; 1.400 pessoas junto com um cantor de importância no país. Vimos crianças, meninos passando mal, tendo que ir com enfermeira. Menino que deixou uma arma para tocar violino e ficou mais com medo de encarar o violino. Precisa de uma concentração, de uma postura. Nesse momento, passa para ele que ele pode ser um indivíduo muito melhor."

Elizabeth Parro, coordenadora geral do Projeto Guri

A apresentação é pensada como um todo, que inclui os momentos preparatórios, o contato com o público, a relação entre os jovens de diferentes pólos, a música, a recepção etc. Nesse contexto amplo, outro aspecto relativo ao resgate da auto-estima é levantado: o encontro com a diferença (representada por pessoas de outra classe social, em espaços antes inacessíveis aos jovens) é visto como instrumento de desenvolvimento da auto-estima.

“[Sair da Febem para apresentações externas] É maravilhoso. É o contato que ele [o jovem interno] tem com o mundão, com as pessoas. Não com as pessoas que ele estava habituado a viver. Pessoa de classe média alta. Isso aumentava demais a auto-estima dele. [...] [Era o momento] mais esperado. Quando tinha apresentação e ele sabia um dia antes, ele não dormia a noite, esperando a 
apresentação. Campos de Jordão foi assim. A emoção de estar indo, estar se apresentando, fazendo alguma coisa boa para alguém...”

Rosemary dos Santos, assistente técnica em Projetos Especiais, área de cultura da Febem

“Os ensaios aproximaram muito os pólos. A realidade de cada pólo é muito diferente. Um viu a realidade do outro. A gente sentiu respeito entre eles. Por exemplo, no pólo do POF, da favela, as crianças são extremamente humildes, diferente de Indaiatuba, onde o nível das crianças é um pouco melhor. Mas eles participaram da mesma mesa de refeição, do mesmo banheiro para se trocar, usaram o mesmo uniforme. Isso é resgate da auto-estima, ele está se sentindo igual perante o público, o evento, a gente.”

Ângela, Projeto Guri

A coordenação artística do projeto 100 muros também destaca a importância de tornar público o conhecimento adquirido como forma de recuperar a autoestima. Nesse projeto, crianças e jovens criaram mosaicos em muros da cidade de São Paulo.

"Estes projetos têm como foco a questão de arte porque modifica as pessoas, a arte transforma... Quando você trabalha com a auto-estima das pessoas, é uma maneira de você trazer um pouco do que a pessoa tem para fora, para ser apreciado, ser colocado dentro de um lugar que não é uma exposição, não é uma pasta, uma gaveta, mas é uma coisa que está recuperando um espaço que está sendo visto, sendo olhado, você se identifica com o que produziu, então isso dá um sentimento de pertencimento, você se legitimou, você existe..." (in Castro, 2001: 369)

Coordenação artística do projeto 100 muros, São Paulo/sp

A partir destes depoimentos e da observação das atividades do Projeto Guri são necessárias algumas ponderações. Quando se afirma o resgate da auto-estima co- 
mo objetivo nos projetos destinados às populações jovens de baixa renda, está se partindo do pressuposto que as crianças e jovens atendidos nesses projetos possuem em comum uma baixa auto-estima. Isto não pode ser afirmado de forma genérica para todo o público atendido pelo Guri, por exemplo. Crianças e jovens de famílias de baixa renda encontram, em outros espaços de suas vidas, formas de construção do gostar de si, de auto-estima. A prática musical e a possibilidade de compartilhá-la com um público amplo são sem dúvida formas de reforçar a capacidade de se respeitar, de se valorizar. Mas não corresponde à realidade pensar essa capacidade como nula antes da participação nos projetos. O discurso dos projetos acaba por constituir a condição da baixa auto-estima como uma realidade a ser combatida, sem investigar de que maneiras as crianças e jovens participantes construíam suas auto-imagens antes da participação nas atividades propostas.

A afirmação da coordenadora dos Projetos Especiais na Febem também precisa ser detalhada. Quando Rosemary afirma que o contato com as "pessoas de classe média alta” aumenta a auto-estima dos jovens, ela efetua uma simplificação que impede a compreensão do que pode efetivamente ocorrer numa situação de apresentação. Como discutirei nos capítulos 4 e 5, o jovem interno na Febem passa por um processo de impessoalização, de humilhação e de invisibilidade, que em nada contribui para a construção de uma imagem de si positiva. A possibilidade do aprendizado musical, de fazer o belo, de mostrar o aprendido para um público é sem dúvida um momento de diferenciação e de construção de sensibilidades para os jovens. O fato é que as “pessoas de classe média alta”, para quem os jovens eventualmente se apresentam, são as mesmas que os conhecem, geralmente, apenas pelo noticiário policial. Mostrar para essas pessoas que eles podem produzir o belo é um desafio e uma afirmação.

No entanto, é preciso observar os espaços alternativos de construção de auto-estima, antes de afirmá-la inexistente. Zaluar (1998) mostrou como o próprio universo do crime (a posse de armas de fogo, a ousadia dos crimes praticados) é constitutivo da imagem do bandido (ela está falando das quadrilhas atuantes nos morros cariocas), e de um sistema de status e poder que marca 
as relações sociais neste meio. No universo da internação também existe um sistema de representações que classifica os crimes cometidos pelos jovens em uma hierarquia à qual correspondem diferentes atribuições de status. O próprio crime $^{58}$ é, portanto, um elemento constitutivo da auto-estima dos jovens: "apresentar o crime como uma escolha é afirmar seu poder de decisão e o controle sobre a própria vida. Significa apresentar-se como protagonista”, analisa Miraglia (2002: 11).

Feitas as ponderações, será necessário ainda observar, como Luiz Eduardo Soares (2001), que a construção da auto-estima por meio da violência corresponde ao "percurso de um atalho pelo avesso da relação interpessoal".

\footnotetext{
"Os meninos impõem o medo para alcançar o reconhecimento de sua presença, para readquirir visibilidade, identidade interativa na dialética dos encontros humanos. A violência dos jovens, nesse caso, é o esforço desesperado de reconstrução do self, esmagado pela negação social mais drástica, aquela que superpõe, à discriminação de classe, o estigma da cor”.
}

Para Soares, essa condição deve ser revertida. A "devolução coletiva da visibilidade seqüestrada" se daria não só pela oferta de emprego, "mas sobretudo pela abertura de espaços valorizados de autocriação simbólico-cultural”. O imaginário do jovem deve ser recuperado "com possibilidades atraentes para a realização de si mesmo, como pessoa”. As atividades artísticas podem ser pensadas como uma via de construção positiva da realização pessoal.

A possibilidade de apresentação pública de uma capacidade adquirida - sempre latente no fazer artístico - tem sido reconhecida como forma de estimular as crianças e jovens participantes dos projetos. $\mathrm{Na}$ análise de projetos de arte-educação realizada pela Unesco (Castro, 2001), afirma-se que a arte permite que os jovens revelem seus talentos para a sociedade, e que a "interação entre a auto-apreciação e a gratificação pelo reconhecimento social” é uma referência para a construção da auto-estima.

A coordenação da Edisca (Escola de dança e integração social para a crian- 
ça e adolescente), de Fortaleza/CE reforça essa idéia: "Elas adoram viajar, fazer sucesso, estar nos jornais, dar entrevista, estar na televisão. Domingo, eles vão estar no Planeta Xuxa. Você imagina o que é uma criança de favela ser o artista principal do Planeta Xuxa? [...] Isso tudo são momentos que lhes vão marcar pela vida toda. E quem passa por um momento de glória, jamais vai querer passar por qualquer outra coisa...” (in Castro, idem: 491)

A participação nos projetos também pode conduzir à mudança de status do participante em seu grupo de origem. Tal mudança seria outro fator determinante com relação à auto-estima do jovem.

“Eles se projetaram. A gente fala 'vou me projetar mundialmente'. Eles se projetaram no mundo deles. Isso é um resgate extremo de auto-estima.”

Ângela, Projeto Guri

Neste sentido, como nota Castro (idem: 490), auto-estima requer também "alter-estima, ou seja, ser bem considerado socialmente, ser respeitado e [...] não serem mais identificados como 'marginais'”.

\footnotetext{
“As experiências investem no resgate da auto-estima, incentivando o jovem para que se sinta sujeito coletivo, que se queira como pessoa, que seja admirado entre amigos e comunidades não por inspirar medo, pelo poder de uma arma, mas pelo poder de produzir prazeres, porque é um artista, um empreendedor, um produtor e consumidor do belo e da arte.” (Castro, op.cit.: 518/9)
}

Na prática, as mudanças podem ser observadas no cotidiano dos jovens, nas relações que travam entre si e com os outros. Na Febem, por exemplo, impressiona ao visitante desprevenido a postura corporal dos jovens internos. Ao andarem nos espaços externos às unidades onde estão internados (para ir à escola, à administração, à biblioteca, por exemplo), mantêm, geralmente, a cabeça abaixada, mãos para trás, ombros caídos ${ }^{59}$. Dificilmente olham nos olhos do seu interlocutor, se este não for outro jovem também interno. No espaço destinado à prática 
musical, porém, outras posturas são experimentadas. Nas aulas, os jovens são estimulados a conhecer as possibilidades de seu corpo na produção de sons, as posturas possíveis para a prática musical; são convidados a deixar para trás tensões que prejudicam, em primeira análise, o fazer musical, mas também o corpo e o ser como um todo. A mudança na relação com outras pessoas e com o próprio corpo opera transformações na forma como o jovem se percebe: ele sente que é capaz de fazer algo que é difícil e belo, ele se valoriza, ele é valorizado por quem o observa fazendo música.

"Quando você entra na Febem, eles não olham para você, eles têm medo de tudo. No Guri, existe uma conquista da equipe que mostra que está chegando para somar e uma conquista de ganhar credibilidade, confiança, respeito. Aí eles começam a criar afinidades. Se soltam, falam o que querem da música, o instrumento que se adaptam melhor, com qual artista que eles querem tocar, começam a participar da história do projeto. Você vê a transformação. Você entra e eles não te olham, não conversam. Com o tempo, existe uma conversação entre eles, professores, diretores da unidade. Depois saem dali e vão para o palco tocar com Paulinho Nogueira eYamandu, fazem ensaio, você vê a transformação das meninas: no rosto, no olhar. Ouve dizer: 'eu vou sair daqui e quero continuar a aprender o instrumento'.”

Elizabeth Parro, Projeto Guri

“... eles têm que ser mais duros, porque estão num mundo que necessita ter dureza. Eles não podem ser moles como a gente. Mas eles choram. Eu já vi um encostar a cabeça no outro e dormir. E eles não fazem isso nas unidades deles. Já perguntei isso a alguns monitores e eles disseram que eles nem se tocam. Mas na aula de coral, parecia uma sala de jantar: 'vamos conversar depois da janta'. Encostavam um no outro e dormiam, riam, e não era um riso forçado, riam porque estavam gostando do que estavam fazendo. Era uma atividade muito importante para eles."

Regina Kinjo, regente dos corais dos pólos Febem e Mazzaropi do Projeto 
Guri

A conquista da auto-estima na prática artística é vista como um bem de "longa duração", que ultrapassa a temporalidade do fazer artístico, com repercussões na vida do jovem, mesmo após a interrupção da prática.

"[Fora da Febem] Ele não tem um violino, não tem o canto, mas adquiriu dentro dele aquela auto-estima de ser capaz, de poder valorizar a vida. Porque muitos dos meninos aqui não valorizam a vida. Não querem nem saber se vão morrer amanhã. Valorizar [é] então: eu sou capaz, eu posso viver, posso ser feliz. É muito frustrante para o nosso trabalho você não poder dar continuidade. Mas você vê retornos: mesmo sem ter continuidade lá fora, esse menino percebeu que é capaz, que é um ser humano. Não é só a música, são outros valores que foram despertados dentro dele.”

Rosemary dos Santos, Projetos Especiais/Febem

Tal visão de futuro também é ressaltada pelos autores da pesquisa promovida pela Unesco. O resgate da auto-estima, na opinião de educadores, pais, mães e jovens pesquisados, além de contribuir para o afastamento de situações de risco, como crime organizado, violência e drogas, tem um sentido que "vai além do imediato, do presente, é um se querer que se nutre da apreciação por outros, de forma positiva” (Castro, 2001: 487). "Auto-estima, para muitos, remete a projetos, à visão de futuro, indo contra a onda do desencanto e do 'eterno presente' (Jameson)" (idem: 488).

Cabe notar, por fim, que a associação entre práticas de arte-educação e desenvolvimento infanto-juvenil está presente em alguns dos principais documentos relativos à infância e juventude brasileiras - independentemente de classe ou situação social. O Ministério da Educação publicou, a partir de 1998, os Referenciais Curriculares da Educação Infantil e os Parâmetros Curriculares Nacionais, documentos nos quais é enfatizado o papel das artes na educação. Também o Estatuto da Criança e do Adolescente, em seu capítulo Iv, versa sobre o "Direito à educação, à cultura, ao esporte e ao lazer". O Artigo 53 determina 
que “A criança e o adolescente têm direito à educação, visando ao pleno desenvolvimento de sua pessoa, preparo para o exercício da cidadania e qualificação para o trabalho". O Artigo 54 aponta como dever do Estado assegurar à criança e ao adolescente, entre outros benefícios educacionais, o "acesso aos níveis mais elevados do ensino, da pesquisa e da criação artística, segundo a capacidade de cada um” (art. 54, parágrafo v). Inclusive o respeito aos "valores culturais, artísticos e históricos do meio da criança e do adolescente" é previsto no ECA (art. 58), visando a garantia de liberdade de criação e o acesso às "fontes de cultura".

\title{
cidadania
}

\begin{abstract}
“A auto-estima é uma coisa mais individual... Se a pessoa se valoriza mais, se considera mais, ela vai ter uma segurança maior para se colocar como cidadã. Para exigir seus direitos como cidadã, desempenhar as funções como cidadã. Cuidar do espaço que vive, cuidar das outras pessoas. Só a partir do cuidado consigo próprio, é que uma pessoa pode passar a entender realmente o que é o cuidado com os outros, o que é o respeito aos outros. Ser cidadão é respeitar o direito dos outros, é cumprir com as obrigações. Mas se isso não for entendido pela própria pessoa e se ela não tiver segurança na ação do dia a dia, é muito difícil ela compreender como socialmente pode atuar.”

Maria Corina Gama de Macedo - coordenadora da Casa do Zezinho
\end{abstract}

Nesta fala, auto-estima e cidadania são colocadas como termos de uma mesma sentença, interligados, íntimos. Tal associação se dá no discurso de vários proponentes de projetos de forma direta, sem intermediações: se faz música, dança, pintura, para se “tornar cidadão”. No entanto, tal passagem do plano do sensível ao da política não é necessariamente simples. Como com os demais termos daquele "vocabulário de sentidos", os sentidos de "cidadania" nesses projetos possuem pouca relação com a definição clássica do conceito.

Uma aproximação possível seria se pensar a arte como um direito de cidadania, previsto na Constituição e no ECA. Castro (2001: 13) faz essa conexão: 
“Ao discutir políticas públicas que contemplem os jovens, costuma-se considerar arte, cultura e esporte não como atividades complementares à formação e ampliação do acervo de informações, mas como um direito de cidadania com repercussões múltiplas, contribuindo para valores positivos, para um re-encanto sobre a vida, que beneficiariam não somente os jovens, mas à sociedade em geral.”

Por outro lado, existe a necessidade de se pensar simultaneamente as noções de direitos e deveres. Luciana Guimarães, diretora de projetos do Instituto Sou da Paz, defende propostas que contemplem uma "educação para autonomia”, que evidenciem que direitos são conseguidos com participação, responsabilidade, cobrança. Critica, em vários projetos de arte-educação, um caráter assistencialista, no qual os jovens são mais “elementos decorativos ou objetos de trabalhos” e menos protagonistas ou parceiros na elaboração das propostas.

O Sou da Paz tem como preocupação central em seus projetos a promoção da cidadania para o jovem. Sem atuar diretamente na área de arte-educação, a coordenação do Instituto desenvolve um olhar crítico a propostas que reforçam o caráter "ocupacional” da atividade oferecida ao jovem, e o lugar "decorativo" deste, em vez de transformador.

“A sensação que temos é que o discurso sobre violência de quem trabalha nessa área de cultura é um pouco ocupacional: 'dá uma coisa para esses jovens fazerem, porque aí eles não cometem crimes, não vão para as drogas'. E não usam isso como instrumento de transformação. Deveriam usar esse espaço que mobiliza para algumas reflexões de cidadania. O jovem não vai lá só para tocar um instrumento ou fazer uma peça, mas ele vai ter que participar do processo de elaborar as coisas, pensar como se executa aquele projeto, vai ter que avaliar, pensar como vai divulgar. Que o protagonismo - e não gosto muito dessa palavra - não seja só na apresentação de resultados, mas de participação em todo o processo, desde a elaboração até a avaliação. Para nós não interessa o tema, o projeto de cultura, mas o processo. Nossa preocupação é 
mais em transformar a atuação, do que o acesso à cultura em si.”

Luciana Guimarães, diretora de projetos do Instituto Sou da Paz, São Paulo

A pesquisa junto ao Projeto Guri mostrou que a prática musical efetivamente mobiliza mecanismos de sociabilização, de criação de identidades, reforça sentimentos de pertencimento, amplia horizontes espaciais e alteridades ${ }^{60}$. Isso não é pouco. No entanto, a passagem entre o fazer musical proposto pela instituição e a efetivação dos objetivos mais amplos, como a construção da cidadania, é, às vezes, superficial, conflituosa ou pouco trabalhada.

O contato com diferentes grupos, públicos e espaços é, potencialmente, um instrumento de cidadania, mas, se pouco trabalhado, pode resultar na exacerbação da diferença. As falas que reproduzo explicitam o conflito e a dificuldade da transposição do status adquirido no palco para fora deste.

"Eu quero falar o seguinte: nós viemos aqui pra cantar - não para ser esculachado - pra mostrar o que nós sabe. Não é porque nós é da Febem que vai ficar tudo como vagabundo, como bandido. Cantar nós também sabe... [os alunos do pólo Mazzaropi] São tudo playboyzinho, filhinho de papai, mamãe.

A outra orquestra [do pólo Mazzaropi] olhou para nossa pessoa e balançou a cabeça fazendo 'ssss'. Tipo tirando nóis, 'a gente não somos nada'. Eles são tudo boyzinhos, eles pode, nós não pode...

Tem muita pessoa que vê a gente como animal, não vê a gente como ser humano. Porque nós roubamos, erramo, tudo bem. Mas não, eles criticam. Porque nós somos de periferia. E quem fala isso é boyzinho, filhinho de papai. Nós tava em cima do palco cantando. O que é que tinha que um olhar para o outro, balançar a cabeça e fazer 'ssss'?

Nós aprendemos o que tinha que aprender em um mês. Eles não; tiveram tempos e tempos para aprender. Nós suamos, demos sangue para tocar em um mês, só que essa oportunidade não foi dada pra nós."

Estudante de violino no pólo Febem 
“A sociedade, na hora, até pensa: eles têm um certo talento. Mas saindo de lá, eles tratavam da mesma forma. Febem é Febem e vai continuar sendo. Isso a gente via no tratamento deles: quando os meninos estavam saindo do palco, todo mundo cumprimentava, parabenizava, e os meninos saiam de lá super cheios, vaidosos. Só que se chamasse alguém do próprio público para conversar com eles, acho que não teria ninguém que iria. Ninguém ia à sala e falava parabéns. Isso acontece no Mazzaropi. Tem gente que vai no fim da apresentação ao local onde estamos e fala 'parabéns, gostei da sua voz'. $\mathrm{Na}$ Febem, enquanto estavam na frente, eram artistas e tinham valor. Só que quando saiam do palco deles, do palco delimitado, viravam Febem de novo, a mesma coisa."

Regina Kinjo, regente dos corais dos pólos Febem e Mazzaropi

Um dos termos-chave do "vocabulário de sentidos" criado pelos pesquisadores da Unesco é “protagonismo juvenil”. Ele traduz uma ação pela participação dos jovens nos contextos em que estão inseridos, no sentido de co-organização, de proposição de caminhos, para a concretização da condição de cidadania. No caso do Guri, tal participação ainda é restrita. Alguns jovens que se destacam podem vir a ser monitores (auxiliando o professor no ensino aos iniciantes), formal (contratados pela Secretaria de Cultura) ou informalmente. Mas a participação efetiva na formatação das atividades do projeto ainda não se dá. Talvez um caminho para a concretização de objetivos mais amplos seja ouvir, além da música dos jovens guris, seus anseios. 


\title{
III. ETNOGRAFIA DO APRENDIZADO MUSICAL
}

[MÚSICA, IMERSÃO, MIMESE E CORPORALIDADE]

\begin{abstract}
"Vamos começar de novo! Você não diz 'bom dia'? Vocês vão dar aula para crianças que chegam ao Guri e, muitas vezes, não ouviram até então um 'bom dia'. Crianças que apanharam do pai, da mãe; crianças na Febem, que só levam porrada. Para elas, pode ser mais importante ser bem tratado por dez minutos do que aprender um instrumento”.
\end{abstract}

A orientação do maestro ao jovem estudante que ensaiava os primeiros passos como professor, regendo seus próprios colegas da Orquestra Paulista Juvenil do Projeto Guri ${ }^{61}$, foi inicialmente acompanhada pelo riso da classe. O colega, ansioso por testar sua habilidade como professor, esquecera de cumprimentá-los. O riso, no entanto, foi rapidamente substituído pelo silêncio; a voz do maestro, sem qualquer dificuldade, chegava a toda a sala de ensaio. A primeira lição da aula fora dada pelo experiente músico ao aspirante a professor e aos cerca de 50 jovens estudantes que empunhavam seus violinos, violas, cellos e contrabaixos. Provavelmente, a lição do maestro não era desconhecida por muitos dos jovens presentes na sala. E o "bom dia” proferido logo em seguida pelo jovem que experimentava o lugar do professor pode efetivamente ter sido, para alguns, o primeiro ouvido naquela manhã de sábado.

Neste capítulo, analiso a proposta pedagógica do Projeto Guri e as implicações da opção pelo ensino de instrumentos de orquestra e pelo aprendizado coletivo, seja em aulas em grupo ou nos ensaios de orquestras e corais. O foco será o espaço da transmissão do conhecimento musical, e aqui a análise não vai se ater a avaliar o aprendizado musical, mas, a teia de sentidos que o envolve. Pressuponho, como explicita a situação de aula descrita acima, que em um contexto no qual a música é um instrumento de intervenção social - ou seja, não se tem 
como única finalidade a dimensão estética - a aula passa a ser locus de transmissão de valores, de experiências, de imagens que ultrapassam a esfera musical e atingem a vida dos praticantes como um todo.

A proposta neste capítulo é, portanto, a realização de uma etnografia da aula. Com relação ao aprendizado propriamente, interessa-me a relação entre oralidade, escrita e corporalidade na aquisição musical. A etnografia revela que não há, na prática observada, uma demarcação rígida entre música popular - e um suposto universo de oralidade - e erudita - de base e transmissão escrita. A análise da corporalidade - além da oposição escrita x oralidade - mostra-se fundamental para a compreensão das formas de aquisição de um saber, de difusão desse saber e das contradições que o mesmo pode colocar com relação aos momentos vividos pelo jovem. Interessa-me, portanto, o universo de sentidos mobilizados no aprendizado musical. Qual a relação entre a experiência sensível e uma "educação sentimental”, tal qual formulada por Clifford Geertz (1983)? Como se dá a transmissão de conhecimento e de valores? Que tipos de comunicação se estabelecem entre alunos, entre estes e professores, de todos com a música? Qual a mimese entre música e vida cotidiana?

\section{Projeto Guri}

O Projeto Guri é uma iniciativa da Secretaria de Estado da Cultura de ensino musical para crianças e adolescentes "de famílias com baixa renda", ou "internados e desinternados da Febem" ${ }^{62}$, de 08 a 18 anos $^{63}$. O projeto, que teve início em 1995, na Oficina Amácio Mazzaropi, com a participação de 180 crianças e adolescentes, conta em 2003 com cerca de 100 pólos, atendendo cerca de 25 mil crianças em todo o Estado. Ao todo são 45 orquestras mirins, 25 cameratas de violão, 42 corais, 6 big bands e 22 conjuntos diversos. Além da ampliação de seu alcance, o Guri recebeu importantes prêmios, como o Prêmio Multicultural do Estadão, de melhor projeto de fomento à cultura, em 2000, participou do Encontro Internacional da Rede Global de Educação para a Paz, na Suíça, e foi 
o programa escolhido pelo Ministério da Educação para representar as crianças brasileiras na Sessão Especial da Assembléia Geral das Nações Unidas em Favor da Infância, na sede da oNu, em Nova York, em maio de 2002. Nessa ocasião, duas alunas de violino do projeto viajaram aos Estados Unidos para representar o país. Em outubro de 2000, Juliana Silva Castro, de 11 anos, aluna do pólo Mazzaropi do Guri, recebe o primeiro prêmio do XII concurso nacional de violão Souza Lima. Outra marca do projeto são as apresentações de seus conjuntos com importantes músicos brasileiros, como Artur Moreira Lima, Toquinho, Celine Imbert, Antônio Nóbrega, Morais Moreira, Fortuna. O trabalho das orquestras e corais já está registrado em três cDs, dois com Toquinho e um de hinos, lançados ao longo dos 8 anos do Projeto.

A introdução musical dá-se principalmente por meio da formação de orquestras didáticas e corais, nos quais os alunos têm contato com repertório erudito e popular, em aulas em grupo, bem como ensaios gerais com maestros, visando apresentações externas.

Nos pólos, os alunos freqüentam, em geral, duas aulas por semana de coral ou de instrumentos ${ }^{64}$. As aulas, de uma a duas horas, são geralmente em grupos, que variam entre dois e cerca de 20 alunos; eventualmente, há separação entre iniciantes e avançados. O ensino de teoria se dá durante o aprendizado do instrumento ou em aulas específicas com um maestro. Este é também o responsável pelo ensaio da orquestra, que ocorre após as aulas. A idéia é que cada pólo tenha uma orquestra e um maestro. A proposta do Guri é que, com pouco tempo no projeto (em alguns casos, cerca de um mês), os alunos passem a participar da orquestra.

Além da participação precoce na orquestra do pólo, outras peculiaridades do projeto chamam atenção: o contato imediato com o instrumento ${ }^{65}$ e o rápido acesso a um repertório erudito e popular com arranjos simplificados. Tais características do Guri serão analisadas como estratégia de pedagogia musical e de intervenção social. 


\section{O erudito: entre o exótico e o familiar}

Ao escolher um projeto como o Guri para a análise do fazer musical entre crianças e jovens de baixa renda no Brasil - mais especificamente em São Paulo - uma questão sempre é colocada (a mim, pesquisadora, e por mim ao objeto pesquisado): por que o ensino de "música erudita" em um país com tão forte tradição popular? E ainda: por que estudar esta iniciativa, tão "institucional”, e não manifestações "genuínas" da cultura musical nacional? A colocação desse tipo de questão e as respostas que o campo dá a elas fornecem pistas sobre importantes representações e estereótipos da elite e das camadas populares brasileiras sobre a cultura musical nacional, e precisam ser analisadas detidamente.

O mosaico das imagens sobre o fazer musical no país pode começar a ser composto com as representações do proponente. Cabe notar desde já que as falas da coordenação do projeto não são consonantes todo o tempo. Há sobretudo uma diferença entre o olhar da coordenação técnica e dos músicos que compõem a coordenação e o corpo docente do Projeto.

Reproduzo a seguir um trecho de entrevista com Elizabeth Parro, coordenadora geral do Guri.

\section{P: Qual a especificidade da música com essa faixa populacional?}

Elizabeth Parro: Você chega em um espaço pobre, miserável e instala um pólo: você compra uma orquestra e deixa aqueles instrumentos à disposição de crianças e adolescentes que nunca teriam acesso a esse tipo de curso, que custaria hoje cerca de 250 reais por mês. Você envolve pai, mãe, tio, irmão, que vai lá e assiste a um espetáculo em que a filha está se apresentando. Você imagina o que isso transforma na vida das pessoas. Você forma público em erudito! Onde o pobre tem acesso à música clássica, ao erudito, nesse país?

\section{P: Por que a escolha do erudito?}

R: Porque você consegue com o clássico a concentração, a responsabilidade... Para tocar um tambor, é uma coisa mais simples. Para tocar vio- 
lino exige uma concentração muito maior. Exige postura, responsabilidade, compromisso. Por isso nós fomos para o clássico. Eles formam uma família. Ali, quando estão juntos, há uma concentração tão grande, que um precisa do outro. Ele não toca sozinho numa orquestra. Vai ter que estar sempre contando com o amigo do lado. Isso faz parte da educação através da música: respeitar o próximo. E você conversa com eles e eles falam: mudei minha organização em casa, o tratamento com minha mãe. Na Casa de Solidariedade [onde funciona um dos pólos do Guri], trabalhamos com crianças de cortiço. Imagina o que é colocar os meninos na sala de aula e naquele momento fazer com que eles parem para ouvir. Eles têm que se ouvir.

$\mathrm{Na}$ fala da coordenadora geral do Guri a música erudita é associada a uma cultura de elite, amparada em um julgamento econômico (aulas e instrumentos caros), cultural (música clássica inacessível ao pobre), e de ethos musical (concentração e responsabilidade associadas ao aprendizado erudito). A fala deixa ver ainda um desconhecimento musical, que leva ao preconceito com relação ao popular (suposta simplicidade do tambor).

Cabe notar que tais valores não são exclusivos da coordenação desse projeto. A associação da música erudita a uma cultura elitista corresponde a um senso comum sobre música e cultura no país. Os preços exorbitantes de ingressos para concertos em algumas salas ${ }^{66}$ corroboram tal impressão. No entanto, os eventos gratuitos - em praça pública ou anfiteatros - costumam atrair um público bastante significativo, que certamente não é constituído somente por pessoas de alto poder aquisitivo. Também o músico de orquestra tem origem sócio-econômica variada, como veremos em depoimentos abaixo.

A atribuição de qualidades como responsabilidade e concentração ao aprendizado erudito, efetivamente observáveis na prática musical, é acentuada por tratar-se de um projeto de cunho social, no qual tais qualidades são destacadas dentre outras, também relevantes, porém menos significativas aos olhos do público e da mídia. A observação abaixo, publicada no jornal O Estado de S.Paulo, confirma a valorização daquelas qualidades: 
“Tímidos e reservados, os novos músicos mal levantam os olhos para falar sobre a experiência. Com os instrumentos, porém, deixam de ser 'os meninos da Febem' para assumir uma postura de profissionais, sérios e compenetrados." In O Estado de S.Paulo, 26/7/97; itálicos meus

Para coordenadores e professores do projeto, a suposta distância do ensino proposto pelo Guri das experiências culturais de seu público não é um problema, mas um trunfo: acredita-se que o contato com instrumentos e repertórios diversos levará à ampliação do universo cultural dos jovens e de suas comunidades.

Pergunto: Por que oferecer instrumentos de orquestra para um pessoal que não teria acesso normalmente a esse tipo de instrumento? Por que não oferecer violão e cavaquinho?

Maestro Asa: Depende do público. Aqui [no Mazzaropi] não é assim. No pólo São Remo [na favela de mesmo nome] é assim. Começou só com violão, cavaquinho e percussão. Mas já estão sendo implantados trombone, trompete, clarinete, sax, flauta, violino, viola, violoncelo e contrabaixo acústico.

P: Qual o objetivo de ampliar?

R: Dar mais oportunidades para as pessoas. No São Remo, vejo que muitas pessoas não sabem nem que existem determinados instrumentos. Muitas vezes, me deparo com pessoas ouvindo na porta e vendo qual instrumento produz aquela sonoridade. É legal saber que não existe só violão, cavaquinho e pandeiro. Eu acho demais violão, cavaquinho e pandeiro, mas tem que ter as outras coisas também. Acho que o objetivo do projeto é dar um pouco mais de elucidação musical, de musicalização, de conhecimento de outros instrumentos e outras sonoridades, do que pode ser feito em música de uma maneira geral, global e mais profissional até.

Na fala da supervisora técnica do Guri, Ângela Maria Visconti, surge um aspecto interessante com relação ao gosto musical: a aproximação entre "nós" e "eles". 
Ao mesmo tempo em que afirma a necessidade de "conquistar" o outro para a música erudita, reconhece que essa música não é estranha somente aos pobres, mas ao brasileiro em geral.

"Fazemos um estudo do público com o qual vamos implantar o projeto. Para a favela, por exemplo, a gente levou a orquestra, porque tem instrumentos que eles não conhecem. Nós temos clareza que para conquistá-los é preciso primeiro chegar na realidade deles. Não adianta ir lá com uma obra belíssima de Beethoven, ou Chopin, que eles não vão ouvir, não é a realidade. Se eu começar com músicas mais próximas da realidade deles -cavaquinho, violão, percussão, música popular brasileira - e aos poucos for introduzindo coisas que não fazem parte da realidade, fica mais fácil assimilar. Porque aí eles já têm o que é deles e vão adquirir aquilo que não é. Mas se logo jogar uma realidade que não é deles, nem brasileira em si... Não é só porque são de favela que não ouvem música clássica, a gente também não ouve...”

Ângela Maria Visconti, supervisora técnica do Projeto Guri

Aqui fica explícito outro objetivo do projeto, segundo seus proponentes: a formação de um público qualificado.

"Além da atividade pedagógica, do reforço da auto-estima, o Guri prepara eles para um prazer muito grande, que é ouvir música. No Brasil, muitos dos grandes músicos são filhos de maestros da força pública, da banda da polícia militar. São filhos de músicos de banda, que acabaram entrando na música porque viveram aquilo. Esses meninos também. Porque o Guri não é só exercer a atividade musical. Acho que vai formar músicos e ouvintes qualificados."

Melanie Farkas - Presidente da Sociedade dos Amigos do Projeto Guri

"Todos que estamos aqui somos profissionais. Nosso prêmio será encontrar nossos alunos numa vida profissional, talvez. Ou, se não quiserem seguir a 
profissão, aprenderam pelo menos a ouvir.”

Valter Batista de Azevedo, “Asa”, maestro da orquestra do pólo Mazzaropi

O maestro João Maurício Galindo, além de destacar a formação de um público ouvinte como um dos propósitos do ensino musical, lembra que a música de orquestra não é uma atividade de elite. No capítulo 2, apresentei sua argumentação, exemplificada com o fato dos músicos das orquestras que dirige serem de famílias de baixa renda. Galindo também lembra que os concertos gratuitos ou com preços populares são freqüentados por um público numeroso, o que indica o alcance desse tipo de música.

\section{música de culto}

Galindo retira a música erudita do lugar exótico e distante na qual é comumente colocada, inclusive pela própria coordenação do projeto. Depoimentos de vários dos alunos que entrevistei confirmam a indicação do maestro. Muitos desses, crianças e jovens de famílias de baixa renda, procuraram o projeto em virtude de um interesse anterior no aprendizado do instrumento de orquestra. Conheceram o instrumento ou algo do repertório erudito com familiares que faziam música ou, muito comumente, em igrejas, sobretudo evangélicas, que têm corais e orquestras que se apresentam nos cultos. É notória a presença de músicos que iniciaram seus estudos na igreja nas principais orquestras profissionais do país. $\mathrm{O}$ mesmo se dá no Guri.

"Vários [dos alunos do Guri] são evangélicos. A igreja evangélica tem muita importância no movimento musical. Eles gravam discos, contratam profissionais, arranjadores, músicos, todas as igrejas têm orquestras grandes ou pequenas. Eles vêm para cá para aprender um pouco mais. Muitos estudam para tocar na igreja deles, mesmo.”

Maestro Asa 
Em uma das primeiras visitas ao pólo Mazzaropi, em 1998, questionei um menino de 11 anos, estudante de flauta transversal havia um ano e meio, sobre o motivo que o teria levado ao Guri. Ele respondeu que decidiu estudar "porque 90\% das crianças sabem música”. A resposta, inicialmente inquietante, fez sentido com a explicação do menino: em sua igreja, a Primeira Igreja Batista, de Princesa Isabel, "quase todo mundo sabe tocar algum instrumento", alguns o fazem durante os cultos. Quem o levou para o Guri foi uma professora do projeto que tocava na igreja. No momento da pesquisa (1998), Boaz orgulhava-se de ser o mais novo integrante da banda que tocava nos cultos, formada por outros sete músicos. Ele também era o solista de seu instrumento em apresentações da orquestra.

O Guri acaba por se configurar como uma alternativa ao aprendizado musical oferecido por algumas dessas igrejas. Segundo alguns dos jovens com quem conversei, o "problema” dos cursos na igreja é o longo período no qual não se tem contato com o instrumento, já que só são ministradas aulas de teoria. O contato imediato com o instrumento, no qual se baseia o método do Guri, contrasta radicalmente com essa realidade, atraindo parte desse público bastante numeroso.

\section{música em casa, música de trabalho}

Para outros jovens, a música é uma espécie de herança familiar: pais, tios ou outros parentes tocam algum instrumento, há um ambiente musical na vida familiar, a música sempre fez parte da vida deles. Interessante notar que para esses jovens geralmente não importa o fato de se aprender música erudita ou popular, instrumentos de orquestra ou não. O importante é se fazer música, e se ter o instrumental para tal.

O jovem que deu a aula apresentada no início deste capítulo, Agenilson, de 19 anos, toca contrabaixo acústico no Guri há dois anos e há um ano e meio participa da Orquestra Paulista Juvenil do Projeto Guri, da qual podem fazer parte estudantes do Projeto que já estão mais avançados. Mora em Santos, onde é também monitor do pólo. A música está em sua vida desde sempre: começou a 
aprender violão aos cinco anos com o pai. Já tocou guitarra, contrabaixo elétrico, teve uma banda de rock. No Guri, começou com o violoncelo, mas gostou do baixo. Questionado sobre a diferença dos repertórios (erudito/rock), afirmou que "são extremos", e que gosta mesmo é de jazz. Agenilson, que também estuda na Escola Municipal de Música ${ }^{67}$ (contrabaixo acústico erudito) em São Paulo e toca à noite em uma danceteria de Santos com banda (“de rock, música eletrônica"), vê no aprendizado erudito a possibilidade de profissionalização. Conta que seu professor recomendou o estudo do erudito "porque com jazz não se ganha a vida no Brasil”. Para o jovem, o erudito é "obrigação, trabalho", enquanto o jazz seria a união do trabalho com a diversão.

Música como trabalho é realidade para Cláudia, violista da Orquestra Paulista, professora do pólo de Santos há poucos meses. A música também é, para Cláudia, uma herança: na família, todos tocam algo, como amadores. Ela começou a experimentar os instrumentos pequena, sempre aprendendo "de ouvido", sozinha. "Comprava os livros, aprendia na marra". Também toca violino, cello, saxofone. No dia da aula de Agenilson, Cláudia fora convidada pelo maestro Emiliano para tocar com um grupo dele "na Sala São Paulo, com cachê e transporte!”, orgulhava-se. Cláudia toca de tudo (tango, МРв, pop, erudito), em casamentos, igrejas, na Orquestra da Faculdade de Santos, jantares. O que mais gosta de tocar e ouvir? "Barroco" - resposta direta, que desnorteia visões mais estreitas, desautoriza preconceitos estético-sociais.

Agenilson e Cláudia são jovens que encontraram no fazer musical uma possibilidade de profissionalização. Com poucos anos de estudo do instrumento de orquestra já "fazem cachês” (recebem pela apresentação em casamentos, danceterias, jantares), tocam em orquestras, não imaginam seu futuro - profissional e pessoal - sem a música. Em comum com vários dos participantes do Projeto Guri, são jovens provenientes de famílias de baixa renda, dependem de auxílio para transporte para viabilizar a ida ao pólo para o ensaio, não estudariam se tivessem que pagar por isso. Cláudia tem uma posição privilegiada no grupo, por fazer “vários cachês”, tocar em uma orquestra profissional de Santos, já ser professora de pólo, em suas palavras, "ganhar a vida com a música”. Sua situação é considerada exem- 
plar pelos colegas de pólo, que começam a formar pequenos grupos para "fazer cachês" em casamentos. Nestes casos, o aprendizado do instrumento de orquestra é completamente desvinculado do caráter exótico com o qual iniciei este mosaico. É uma formação que possibilita ao aprendiz tornar-se músico, "tocar de tudo".

\section{“importante é respiração, não repertório”}

No pólo POF/Morumbi do Projeto Guri, o aspecto da apropriação da técnica aprendida para o fazer musical mais geral ficou evidente durante a pesquisa. $\mathrm{O}$ POF (Posto de Orientação Familiar) fica entre as favelas de Paraisópolis e Porto Seguro, e é mantido pela Federação Israelita. As atividades do Guri são oferecidas para grupos que fazem a complementação escolar (recreação, esportes, teatro, informática e refeições) no Pof e para jovens moradores nas favelas das proximidades. Acompanhei aulas das turmas de violão e canto, as únicas modalidades oferecidas neste pólo. Nas aulas de violão, o método privilegia o aprendizado do dedilhado, inicialmente identificando as notas por seu nome, para depois introduzir a representação gráfica (notas). Os alunos aprendiam, portanto, a tocar as melodias de músicas populares (como Asa Branca) ou eruditas (como Ode a Alegria de Beethoven), sem no entanto desenvolver outro aspecto bastante comum e importante do instrumento que são os acordes para acompanhamento de melodias. Ou seja, os alunos do POF aprendiam a dedilhar as melodias das músicas, mas não aprendiam a tocar, por exemplo, o instrumento como acompanhamento de uma canção, seja rock, samba, pagode...

A mim, tal forma de aprendizado parecia incompleta. Em minha formação como violonista, sempre tive aulas de "clássico" (a forma mais comum de se designar o aprendizado de técnicas e repertório erudito) e "popular”. Nas primeiras, aprendi a ler música em partitura, a reproduzir a música escrita no instrumento. O repertório ia desde melodias tradicionais transcritas de forma simplificada para a tessitura do violão até composições realizadas para o instrumento, complexas, que exigiam domínio técnico e interpretação musical. Nas aulas de "popular", aprendíamos a tocar - e cantar - desde músicas infantis tra- 
dicionais ("Marcha Soldado", “Cai, Cai Balão") até os "hits" do momento: temas de novelas, baladas pop, as canções mais tocadas nas rádios... Esse aprendizado misto possibilitava dois tipos de "usos" do fazer musical: por um lado, estudava por horas em casa com o objetivo de aprimorar a habilidade em tocar composições eruditas que eram ouvidas, no máximo, no interior da casa, por algum familiar que se dispusesse a escutar por alguns minutos a nova música aprendida. Por outro, podia tocar as músicas que todos os colegas conheciam na escola, em viagens: era só chamar dois ou três e começar a tocar. Logo se formava uma roda, apareciam outros tocadores, e tínhamos diversão para um intervalo de aula ou para uma tarde livre.

Questionei, pensando nisso tudo, vários dos jovens alunos do pólo POF sobre o que gostavam de tocar e de ouvir. Queria saber no que o estudo proposto, baseado no aprendizado de melodias dedilhadas, se aproximava (ou se afastava) do que eles esperavam do aprendizado do violão.

Diferentemente do que eu mesma imaginava, todos afirmavam gostar muito da forma como aprendiam o instrumento no pólo. O repertório que admiravam era popular - do rock ao pagode -, mas a este tinham acesso por meio de "revistinhas" e de colegas que sabiam tocar alguma coisa no instrumento. Alguns até compunham músicas dentro de suas preferências. Mas todos afirmavam aproveitar o aprendido no pólo para aperfeiçoar seu modo de tocar. Com a técnica estudada, conseguiam fazer solos, "tirar de ouvido" as canções que ouviam no rádio ou em discos, ficava mais fácil tocar as músicas de seu repertório.

Conversando com jovens que faziam aula de coral no Mazzaropi - dentre os quais alguns diziam gostar de rock, outros, de pagode, um deles até já cantava em bares e tirava algum dinheiro com isso -, ouvi uma explicação definitiva sobre a apropriação do fazer musical proposto pelo Guri: “o importante aqui é você ser um músico, não ser um roqueiro, um pagodeiro. Pra ser músico, tem que saber de tudo. Importante é a técnica. Repertório não é importante. Importante é respiração, essas coisas”.

Cabe notar que no próprio Guri não há uma insistência em um determinado repertório. A observação dos ensaios e apresentações mostra que nem 
sempre a formação orquestral implica a execução de música erudita. "A experiência mostrou-me diversas ocasiões em que foi necessário alterar o material didático a fim de se conseguir os objetivos pedagógicos. [...] O primeiro deles ocorreu nas aulas do Projeto Guri na Unidade Tatuapé da Febem, na cidade de São Paulo. Apesar de disciplinados, os alunos não demonstravam motivação para o aprendizado das melodias e exercícios oferecidos, embora demonstrassem curiosidade pelos instrumentos em si. A motivação só ocorreu quando os exercícios passaram a incluir melodias que os próprios alunos sugeriam.... A insistência na exclusiva utilização das melodias constantes no programa passou a ser estéril" (Galindo, 2000: 3/4). A fala de Galindo é ratificada no cotidiano do projeto. No pólo que o maestro cita, ouvi os meninos ensaiando o tema de Titanic, superprodução hollywoodiana de enorme sucesso, "Azul da cor do mar", "Filho do seu menino", "Marinheiro só", "Herdeiro do futuro" e também a "Ode à alegria”, de Beethoven. O repertório é extremamente eclético: vai do sucesso pop internacional ao fundamento do erudito, passando pela MPB e pelo folclore nacional. Procura adequar-se ao gosto do público, seja ao escolher músicas que são conhecidas do grupo, ou temáticas que lhes são próximas (como a infância pobre, o sonho com o futuro, cidadania).

O fato é que de pólo para pólo, de maestro a maestro, o repertório ensinado no Guri varia bastante. A explicitação dessa característica do projeto - a abertura quanto ao repertório -, que parece de fato ser procurada nos diversos pólos, poderia esclarecer um pouco mais sobre a pedagogia do projeto, que, no entanto, peca por vezes em enfatizar apenas o "ensino do erudito para o povo".

\section{violino, teatro e passarela}

"A minha menina disse que queria ser bailarina, famosa, mas não fez mais, está até gordinha. Eu falei para ela não desanimar, ir fazendo violino, está aguardando vaga para canto. Às vezes, a gente quer ser uma coisa e acaba sendo outra diferente”. A fala de Marina, dona de casa então com 35 anos, mãe de uma aluna do Guri e de outros quatro meninos entre um e 17 anos que não fazem cursos, é 
característica de outra parcela de público do Guri, constituída por pais, crianças e jovens que vêem o aprendizado musical como atividade complementar ao ensino básico. São pais ou jovens que procuram atividades para preencher o horário fora da escola. Ginástica olímpica, circo, teatro são alguns dos cursos oferecidos pelo poder público municipal ou estadual em oficinas culturais, espaços recreativos. Alguns cursos pagos também são citados por vários alunos do Guri quando questionados sobre atividades que faziam fora da escola: curso de modelo e atriz, curso de música na igreja, curso de computação e línguas.

Além do complemento escolar, uma característica de alguns dos cursos citados é a habilitação para uma carreira artística de destaque na mídia - à qual a categoria profissional "modelo" é quase automaticamente associada. A mídia exerce fascínio sobre grande parte dos jovens e mães entrevistados, seja pelo alimento à vaidade de se mostrar para o grande público, seja como possibilidade de ascensão social.

O depoimento de Luzia, de 42 anos, mãe de Eliana, de 10 anos, estudante de violino, é exemplar:

\footnotetext{
“Eliana faz teatro, faz dança, está começando o trabalho de modelo. Descobri aqui [o pólo Mazzaropi do Guri] e ela quis fazer violino. Descobri porque levei ela na Platéia Filmes para fazer teatro, aí nós passamos aqui e vi. Entrei, me informei, assisti ópera, gostei e ela também adorou. Fiz a inscrição para teatro e violino. Ela, na cabeça dela, falou que vai ser atriz. Com fé em Deus. Vai ser atriz e modelo.”
}

O fato do Guri ter algum destaque midiático, inclusive com reportagens televisivas sobre alguns de seus eventos, é bastante relevante para alguns pais e alunos, sendo inclusive determinante em alguns casos. Marcos, de 18 anos, estudante de saxofone, contou que sua família, que nunca o apoiara quando tocava na igreja (Assembléia de Deus), passou a valorizar o estudo do instrumento quando começou a vê-lo se apresentando, "passando na Tv", a ver a professora dele "tocar no Ratinho” (a professora, saxofonista, tocava no programa de televisão do canal 
aberto Sвт). A possibilidade de sucesso - materializado na telinha - levou a família a apoiar até o trabalho de madrugada (ele faz comida japonesa em uma loja após a escola, que cursa no período noturno).

Para os pais, os cursos são além de uma complementação escolar, no sentido pedagógico, uma forma de ocupação do tempo ocioso, uma maneira de evitar que os filhos fiquem na rua, local “perigoso”, onde "se aprende só besteira”. Para os jovens, as atividades extra-escolares são forma de distração, de preenchimento do tempo e de opção à casa. Se a rua é tida como perigosa (sobretudo pelos pais), a casa é sinônimo de ter que ajudar a mãe a lavar roupa, lavar louça, fazer comida. A casa é o local das tarefas domésticas e escolares (lição de casa). Quando questionei alguns jovens sobre o que seria melhor, a música ou a escola, me responderam sem muito pensar que ambos são melhores que ficar em casa ${ }^{68}$.

Apesar da televisão ter papel central no cotidiano do lar, tê-la como única opção de lazer chega a ser um problema:

"Eu também não concordo dela ficar o dia inteiro em frente à televisão. Não tem mais esse negócio de filme pesado só à noite. Agora é direto tudo pesado. Uma menina de 10 anos vai ficar sentada vendo televisão? E as cenas que passam? Acho que não está na hora dela ficar vendo essas coisas. Então, desde os seis anos ponho ela pra fazer qualquer coisa: dança, teatro, catequese. Ela vai sempre na igreja, todos os domingos.”

Interessante notar que a fala é de Luzia, a mesma mãe que valoriza a carreira de atriz e modelo da filha. Ambígua televisão, que repele e atrai...

Seja atividade para matar o tempo, seja por possibilitar alguma projeção pessoal ou profissional, para esse público o aprendizado do instrumento de orquestra ou de repertório erudito não é, necessariamente, estranho ou exótico, mas outra habilidade adquirida dentre as opções extracurriculares. Para entender as motivações que levam à permanência deste jovem no projeto, é preciso adentrar os significados do fazer musical em questão, por meio da análise do método de ensino, da dinâmica do pólo nas aulas e ensaios, e da performance, nas apresentações. 


\section{O aprendizado musical}

Qual a especificidade do ensino musical proposto em um projeto como o Guri? À primeira vista, poderíamos percebê-la no fato dos instrumentos ensinados serem aqueles que compõem uma orquestra, ou no repertório "erudito", oferecido para jovens de camadas "populares", sem acesso a essa "cultura de elite". Como já mostrei, entretanto, é preciso olhar com cuidado para cada um desses termos. O mesmo se dá quando começamos a análise do conteúdo do fazer musical e de sua pedagogia.

Em trabalhos sobre manifestações musicais "populares”, um recurso comum é a comparação dessas com a música ocidental erudita. O primeiro aspecto elencado é, geralmente, a oralidade das manifestações populares versus o caráter visual (escrita) da música erudita. Goli Guerreiro, por exemplo, ao analisar a música percussiva produzida em Salvador (ва), aponta a imitação como "a chave do processo de aprendizagem [...] diferentemente da música erudita onde a escrita em partitura é a forma por excelência de preservar e transmitir o conhecimento musical” (1999: 110)

Não há dúvida que em sociedades sem escrita - convencional ou musical a transmissão do conhecimento implica mecanismos bastante específicos. Inúmeros trabalhos dedicam-se ao estudo de tais mecanismos. No caso do aprendizado musical, este começa, geralmente, ainda na infância, quando a criança observa os mais velhos executando seus instrumentos, canta com sua mãe acompanhando-a nos serviços domésticos, é introduzida nas danças e músicas de festas. A repetição é um mecanismo obrigatório: a tradição deve ser gravada na memória, nos gestos, no corpo de cada membro da comunidade.

Nas sociedades com escrita - e falamos aqui da musical - a partitura é, sem dúvida, uma garantia de preservação de um conhecimento ancestral. No entanto, no processo de aprendizagem musical, a leitura é apenas um dos aspectos relevantes. A observação de aulas de canto ou instrumento, seja no Guri, seja em escolas convencionais de música como conservatórios musicais, mostra que o caráter oral (e mimético) da transmissão musical em sociedades sem escrita 
(musical) está presente também no processo de aprendizagem dos instrumentos de orquestra ou do canto coral. Além disso, o fato de existirem partituras não implica que o conhecimento musical esteja implícito em notas escritas no papel. A partitura pode preservar um repertório, mas o conhecimento musical não se limita à notação ou à sua leitura.

“Ainda não é possível aprender um sistema musical sem ouvi-lo, somente a partir da notação. O aprendizado musical é quase em toda parte uma experiência de intensa relação entre estudante e professor. A identidade, papel social e aproximação do professor de música são importantes componentes de um sistema sócio-musical.” (Nettl, 1983: 329; trad. minha)

A relação professor-aluno, as relações entre aprendizes, bem como a importância da corporalidade na aquisição musical serão desenvolvidas a seguir.

\section{a construção do corpo musical}

\footnotetext{
"Quando eu cheguei aqui, queria tocar outro instrumento, o violão. Mas como não tinha vaga a orientadora de pólo me disse que haveria outros instrumentos de corda e que o violino se encaixava muito bem em mim. Aí eu fiz a inscrição e até hoje estou aqui.”
}

Thais, 12 anos, estudante de violino do pólo Mazzaropi do Guri

O início do aprendizado musical é marcado por uma adaptação do corpo do músico ao corpo do instrumento. A imagem do "encaixe”, citada por Thais, é bastante precisa. O instrumento terá que se ajustar ao corpo do instrumentista e vice-versa, um será a continuidade do outro. Tal processo de construção do corpo musical é, quase sempre, lento e, por vezes, doloroso. Os dedos sofrem com o contato repetido com as cordas do instrumento, ficam machucados, ganham calosidades. Braços ficam doloridos, são comuns tendinites ou dores nas costas. A postura exigida para a execução do instrumento ou mesmo do canto contras- 
ta, constantemente, com a postura cotidiana. Ombros caídos, costas encurvadas, cabeça baixa não "combinam" nem ajudam na produção de sons.

Mas nem tudo é sofrimento nesse processo. Quando Thais fala do "encaixe” do violino com seu corpo há outras razões envolvidas. Uma delas é estética: a orientadora do pólo levou em conta, provavelmente, o tamanho da menina de 12 anos, seu jeito, e associou essas características ao instrumento: pequeno, delicado. O professor que ensinava violino no pólo Mazzaropi na época da pesquisa também destacava dentre as qualidades do instrumento o fato de ser delicado, feminino, e isso refletia sem dúvida na sala com cerca de 15 alunos, a maioria meninas. "Encaixar", nesse caso, é sinônimo de "combinar".

Além do elemento estético, há o próprio ethos associado ao instrumento. Em um livro comemorativo dos sete anos do Projeto Guri, editado pela Secretaria de Cultura de São Paulo, as fotos de alguns dos jovens músicos da família dos metais (trompete, trompa, trombone) remetem imediatamente ao repertório de imagens associadas ao jazz norte-americano de meados do século passado (ver fotos ao lado). Em preto e branco, as fotos mostram não a orquestra, mas o músico solitário, sobre fundo branco, em tom nostálgico e áureo, simultaneamente. Tal imagem associa-se a um determinado imaginário acerca do mundo musical, como o de Agenilson, o contrabaixista que deu a aula aos colegas descrita no início do capítulo, que sonha em tocar jazz. A imagem associada ao instrumento é, na foto impressa no livro, projetada sobre o aprendiz.

“O violoncelo é uma mulher”, argumentou um jovem aprendiz do instrumento, contrariando minha própria percepção, enquanto estudante de cello. A relação entre músico e instrumento passa portanto por uma experiência que é também sensual. Atribuir características humanas ao instrumento é corriqueiro, e confesso que ter ouvido, em minha primeira aula, que o violoncelo possuía alma me confundiu por alguns dias...

$\mathrm{O}$ violoncelo tem de fato alma: é um cilindro de madeira de pequeno diâmetro que une o tampo ao fundo do instrumento. Minha confusão deu-se por ficar em dúvida se a professora metaforizava acerca de alguma característica peculiar do instrumento, ao afirmar sua "alma”, ou se de fato atribuía ao cello 

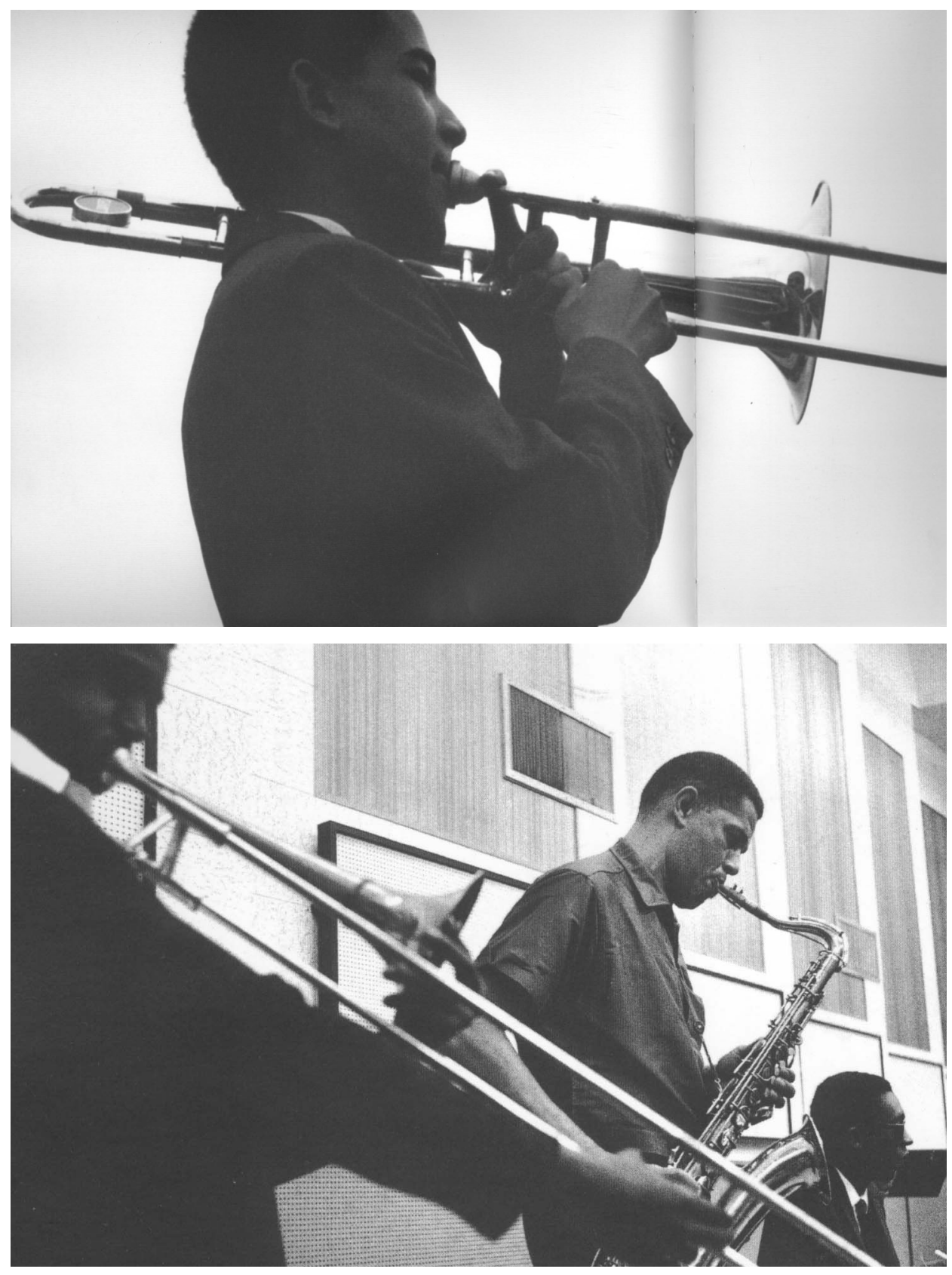

no alto: foto do livro Projeto Guri: 1995-2002. Secretaria de Cultura do Governo de São Paulo, 2002. embaixo: Martin Banks, Dexter Gordon (centro), Dolo Coker, Hollywood, 1957. Foto de William Claxton. In Taschen Diary, 1998. 
uma qualidade metafísica. Não era metáfora nem crença, mas a nomeação revela o tipo de relação que se estabelece com os instrumentos musicais, que, cabe lembrar, também podem ter braço, corpo, boca, língua...

Da alma de volta ao corpo: ao tempo de sua construção musical. No caso dos instrumentos de corda, por exemplo, há uma crença que em muito remete ao descrito com relação ao aprendizado em sociedades sem escrita musical: quanto mais cedo se começa, melhor. O ideal é que a criança tenha acesso ao instrumento já aos 4,5 anos $^{69}$. Em um recente documentário televisivo sobre um famoso violinista contemporâneo, ouvi sua professora dizer: "ele começou aos quatro. Se tivesse começado aos 12 seria um bom músico, mas nunca o gênio que é”. A explicação para a afirmação viria do tempo para a assimilação da técnica: aprendida cedo, permitiria ao músico desenvolver uma musicalidade mais completa.

Outro argumento comumente ouvido no meio musical é que é necessário começar cedo para se obter a "fôrma" da mão: nos instrumentos de corda de uma orquestra, não há as divisões que marcam o espaço a ser pressionado para se obter uma nota, como os trastes do violão ou as teclas do piano, por exemplo. Encontrar a nota no braço do instrumento implica portanto uma técnica que é baseada em uma memória auditiva (busca-se um som previamente conhecido), mas sobretudo física: o corpo do instrumentista aprende quais movimentos deve fazer para que o dedo da mão esquerda atinja a nota buscada. A "fôrma" da mão corresponde ao posicionamento correto dos dedos de forma que uma vez repousados sobre o braço do instrumento reproduzam as notas com exatidão. A “fôrma” não é, obviamente, natural. Mas é uma construção constante de tal maneira que com o tempo - e alguns músicos defendem que este é o tempo de uma vida inteira - a mão se posicione corretamente, "como se" fosse feita para isso, tocar um instrumento.

Para não iniciados - como eu, nas primeiras aulas - isso pode parecer fantasia. Mas o fato é que, aos poucos, o corpo "se lembra": dedos, mão, braço, antebraço, ombro e coluna sabem o que fazer para que a corda pressionada soe a nota desejada. "Confie na fôrma”, lembrava minha professora, solicitando que eu fechasse os olhos e lançasse a mão esquerda em direção à corda, buscando tocar 
a nota que havia lido na partitura. Nessa simples orientação, há tanta complexidade que me parece ser impossível falar em oralidade ou visualidade. É preciso pensar no aprendizado em sua relação com o corpo como um todo.

A prática musical mobiliza mais de uma "razão" sensorial. A audição é fundamental. Ao ouvir o instrumento que toca, o músico pode avaliar a qualidade do som que produz. Se toca com outros músicos, precisa ouvir o conjunto. Ouvindo (um evento ou uma gravação), pode aprender música. Ao acompanhar a música tal qual interpretada pelo concertista, o jovem instrumentista constantemente fica deslumbrado: o que é possível fazer com aquelas notas escritas na partitura! Nas mãos do músico experiente, ganham musicalidade: são frases, com pausas, acentos, sentimento. Há ainda uma audição mnemônica. Quando lê uma partitura, o músico pode ouvir, internamente, a música produzida pela seqüência das notas escritas. Música, no limite, é produzida para ser ouvida.

Não tão óbvio, mas também fundamental na prática musical, é o tato. Uma afinação é ouvida, mas também pode ser sentida: quando toco, por exemplo, a nota dó, pressionando o dedo sobre a corda contra o braço do violoncelo, a corda solta que corresponde a essa nota vibrará se a afinação estiver correta. Tal vibração pode ser sentida ou até vista. A qualidade do som que produzo ao roçar o arco sobre a corda do instrumento depende do controle do peso que meu braço exerce sobre o arco. Meu professor pode "mostrar" o som que devo conseguir produzir fazendo, com sua mão, pressão sobre meu braço enquanto deslizo o arco sobre a corda. Um toque rápido no ombro direito me lembra que devo relaxá-lo e, subitamente, o som ganha volume e brilho ${ }^{70}$. Ainda mais simples: quem nunca ficou arrepiado ao ouvir música? Música toca. Há, ainda, o que Walter Benjamin chamou de conhecimento táti $1^{71}$ : está, por exemplo, na experiência que o corpo guarda do movimento necessário para se produzir um determinado som, como no caso da "fôrma".

A visão também não é dispensável. O músico lê a partitura. Quando esta inexiste, ele pode observar outro músico tocar e aprender: ouvindo, sentindo, imitando. O maestro deve ser visto. Quando se vai a um show ou concerto, espera-se, em geral, ouvir, ver e sentir a música. O maestro João Maurício Galindo, 
na dissertação em que propõe um método para o ensino coletivo dos instrumentos de $\operatorname{arco}^{72}$, ressalta a importância da observação no processo de aprendizagem. As aulas em grupo seriam estimulantes uma vez que "o aluno observa que seus colegas têm as mesmas dificuldades e percebe que os problemas não são só seus" e "ao observar o colega, acha a solução para um problema seu” (Galindo, 2000: 58).

Essa multisensorialidade fica evidente durante a aula de música. As primeiras lições versam geralmente sobre os corpos do instrumentista e do instrumento. O aluno deve conhecer as partes do corpo do instrumento, para que servem, como devem ser cuidadas, limpas. Em seguida, experimentará o "encaixe” do instrumento em seu corpo. Será alertado sobre posições corporais, movimentos, tensões, peso ${ }^{73}$, beleza. O seu próprio corpo será analisado pelo professor no início da prática: é compatível com o instrumento? Para o coral: a voz do aluno está adequada ao grupo? Mudou nas férias?

Mais: é por meio da observação do corpo do professor tocando seu instrumento que se dá parte importante do aprendizado. Observa-se a sonoridade obtida, as possibilidades do instrumento, a posição de alguns dedos no suporte do arco do instrumento, a postura relaxada. Portanto, na relação professor-aluno, mais do que a visão, está em jogo a mimese, a capacidade de observar, imitar e criar uma segunda natureza ${ }^{74}$.

A imitação, ou tentativa de reprodução do modo de execução do solista, ouvido em uma gravação ou assistido em apresentação ou vídeo, não é necessariamente condenada no processo de aprendizagem. Ao contrário, segundo alguns professores, imitar uma execução brilhante pode ser útil para o aluno encontrar sua própria musicalidade.

No processo mimético de aprendizagem, além de visão, observação e imitação, o contato é fundamental. Muitas vezes, ao observar um músico tocar podemos ter a sensação de leveza, quando pode ser essencial o peso na execução do instrumento. Tal sensação e medida de peso, por exemplo, pode ser experimentada quando o professor repousa o seu braço sobre o do aluno, exercendo sobre este a pressão que julga necessária para obtenção do som desejado. O pro- 
fessor também pode pedir para o aluno segurar sua mão ou braço para observar o relaxamento muscular durante alguma execução.

A análise da corporalidade e da mimese envolvidas no aprendizado musical conduz à reflexão sobre as conseqüências éticas, além das estéticas, da prática musical. O caso mais evidente, dentre os observados, é o da Febem. A prática musical - e sua corporalidade - confronta-se diretamente com o controle corporal imposto pela instituição. Como apontarei a seguir, há distinções óbvias como o cuidado com o corpo - manifesto na massagem antes do canto, no alongamento antes da prática instrumental - e a agressão ao mesmo, comum na rotina institucional (nos espancamentos, ameaças, restrições de liberdade e no controle das necessidades fisiológicas). Há também dimensões mais sutis, mas não menos poderosas: ser tocado pela professora que ensina uma determinada postura com suas próprias mãos (e não aos gritos de comando: “cabeça baixa, mãos para trás”); ouvir do maestro o pedido para cantar "mais suave" - e buscar em sua memória a sensação de suavidade; ser perfumado antes de subir ao palco para uma apresentação...

Os exemplos falam de uma forma de conhecimento que não é estritamente visual - como sugerido na comparação entre música popular e erudita de Guerreiro (op.cit.) - mas corpórea, tátil. A prática musical altera, portanto, a percepção geral que o músico tem de seu próprio corpo e a forma como esse corpo passa a perceber o mundo. Richard Schechner reflete sobre a construção do corpo em diferentes gêneros de performances: ao preparar-se para a performance, o performer remodela seu corpo por meio de rigorosos exercícios. "Isso é tão verdadeiro para o kathakali como para o futebol, para o balé como para o xamanismo" (1995: 39; trad. minha). Mas, alerta Schechner, cada forma joga perigosamente com o corpo para desconstruí-lo e reconstruí-lo de acordo com seu próprio plano de ação. "O ciclo de desconstrução e reconstrução começa com o corpo mas não termina aí. O processo joga com as experiências pessoais de vida dos performers" (idem: 40).

Interrompo neste momento a análise com o relato de uma experiência pessoal e não musical. Isto porque, na tarde em que conheci a prática Seitai-Ho, entendi algumas das transformações operadas pela música em meu próprio corpo. 
aula de Seitai-Ho - Estúdio da Curva, Butantã, novembro de 2002

Seitai-Ho é definido por seu divulgador no Brasil, Toshi Tanaka, como "a consciência da natureza do ser humano pela sensibilidade do corpo”. Baseia-se em treinamentos que visam a afinar a "percepção corporal para viver em potencial máximo cada etapa da vida”. É um conjunto de técnicas elaboradas no Japão no início do século xx para manter a saúde, por meio do auto-equilíbrio, do conhecimento corporal, da percepção interna dos movimentos, sentidos e sensações, da observação, e do estudo dos movimentos corporais básicos de uma determinada cultura (a japonesa, por ex.). Pude conhecer tal prática como atividade do grupo de pesquisa NAPedra (do Núcleo de Estudos em Performance e Drama da usp), no qual estudamos, entre outras, a questão das influências orientais em performances ocidentais.

Em determinado momento da sessão - que durou cerca de três horas -, Toshi Tanaka nos convidou a reproduzir o movimento de cumprimentar outra pessoa, apertando sua mão. Em duplas, nos cumprimentamos rapidamente. Toshi pediu então que observássemos o movimento do cumprimento. O caminhar até que a distância entre a dupla permitisse o encontro das mãos, o trajeto percorrido pelo olhar, o calor emanado pelas mãos antes mesmo de se tocar, o toque, o chacoalhar, a separação, o sorriso. Era como se estivéssemos vivendo frame por frame uma reprodução em slow motion de uma cena corriqueira. No entanto, o caráter banal do gesto era totalmente subvertido. Repentinamente, o gesto mais cotidiano do mundo era revestido de sentido: cerimônia, tradição, convenção, por um lado; aproximação, troca, sincronicidade, intimidade, por outro. Encerrado o exercício, todos esses sentidos estavam agregados ao gesto antes banal.

A experiência narrada é bastante abrangente. Mas um momento específico iluminou minha reflexão sobre a construção musical do corpo. Durante a prática do Seitai-Ho, a sensação de observar um determinado movimento corporal com muita atenção, vagar e repetição foi de dejá vu. A reprodução do movimento de dar as mãos e levá-las para cima e para baixo - a base do cumprimento -, em ritmo lento, remeteu-me imediatamente ao aprendizado do movimento do bra- 
ço que segura o arco do instrumento de corda. Sem a ênfase no conhecimento corporal, como na prática oriental, o aprendizado musical havia marcado em meu corpo uma determinada coreografia, que agora eu reconhecia em outros gestos, como no aperto de mãos. Em comum, a música e o Seitai-Ho solicitavam da praticante uma atenção extrema aos movimentos corporais e às possibilidades do corpo. O corpo, quando nesse estado de atenção, pode produzir o belo e incorporar sentidos a essa produção.

Aquele exercício do Seitai-Ho, experimentado em uma curta sessão de uma $\operatorname{tarde}^{75}$, revelou algumas características da transformação musical do meu próprio corpo: as orientações que recebi de meus professores sobre postura corporal, forma de segurar o instrumento e de produzir sons haviam sido incorporadas de forma lenta e, então, automatizadas. A experiência de autopercepção de forma extracotidiana, proporcionada pela prática do Seitai-Ho, permitiu sentir com todo o meu corpo o que havia sido nele impresso pela música: habilidades motoras, resistência muscular, sensibilidade auditiva e tátil. Evidências da impossibilidade de se restringir o aprendizado musical a uma forma de conhecimento unicamente visual.

\section{Música como imersão}

Em uma primeira abordagem das categorias erudito e popular, tais como pensadas pelos sujeitos da pesquisa, observamos o traçado de um trajeto entre o exótico e o familiar. Para boa parte do senso comum - e a coordenação técnica do projeto poderia fazer parte deste - a música de orquestra é exótica, no sentido de não corresponder à sua realidade cultural, de constituir-se como um repertório ao qual somente uma elite - econômica e cultural - tem acesso, ou seja, é um bem simbólico que conota status e diferença cultural e social. No entanto, no cotidiano dos pólos é possível observar uma familiaridade com o instrumento, com a música produzida, com a rotina do fazer musical orquestral que contradiz o exotismo em questão. Dois fenômenos podem explicar tal 
contradição. Um deles é o conhecimento anterior do fazer musical por parte dos alunos - e esse é o caso de parte dos estudantes do projeto Guri, sobretudo no pólo Mazzaropi. Outro é a imersão proporcionada por tal fazer musical, que absorve os jovens, torna-os parte de um novo grupo, empresta-lhes hábitos, modos de agir, gostos, perspectivas profissionais e de vida, sonhos, age em seus corpos e mentes.

\section{famílias de instrumentos, mas não só}

Alessandra é aluna do Guri no pólo Mazzaropi desde a sua fundação, sempre participou da orquestra do pólo e, há alguns anos, trabalha no Mazzaropi como funcionária do Projeto. Foi violinista da Orquestra Paulista Juvenil do Projeto Guri, durante sua existência. Quando a questionei sobre sua experiência na Orquestra Paulista, ela me respondeu: "Na Paulista, tem gente do pólo de Santos, do Mazzaropi, de Indaiatuba. Antes eu pensava: 'nossa família é o Mazzaropi', agora penso que podemos formar outras famílias. A relação que criamos é tipo uma família”. O fato de Alessandra destacar a sociabilidade como um dos fatores principais do Guri e fazê-lo por meio da metáfora da "família” indica a centralidade dessa imagem para o fazer musical neste projeto.

A noção de família, é, por um lado, intrínseca à prática musical orquestral. A orquestra é formada por famílias de instrumentos, designadas como a família das cordas, das madeiras, dos metais. É conhecida a relação bastante próxima entre membros de uma mesma família e até as discórdias e desentendimentos entre músicos de famílias distintas. Fellini nos mostrou, no genial Ensaio de Orquestra, a relação mimética entre músico e instrumento; não é preciso muita imaginação para vislumbrar então que as famílias de instrumentos transbordam sua coesão, suas peculiaridades, seu ethos aos músicos que lhes emprestam o sopro, as mãos, o corpo.

Em um artigo sobre a estrutura das orquestras francesas, Bernard Lehmann (1995) argumenta que entre os instrumentos há hierarquias e diferenças que corroboram a diferenciação social dos músicos. Segundo o autor, as dife- 
renças podem ser observadas em diversos aspectos da orquestra. Haveria, por um lado, uma valorização dos instrumentos de timbre agudo: estes, por serem mais reconhecíveis na massa sonora da orquestra, seriam os mais valorizados, individualizados, enquanto os graves, dificilmente identificáveis no conjunto, serviriam como base, perdendo em destaque e brilho. Também a topografia da orquestra refletiria tal diferenciação: à esquerda, ficam os instrumentos agudos, à direita, os graves. À mão esquerda do maestro caberia exprimir, dar alma à obra, enquanto a direita, aquela que segura a batuta, indica o tempo, de forma mecânica, em suas palavras, "metronomicamente”. As famílias de instrumentos também teriam suas peculiaridades que denotam as diferenças sociais dos músicos: quanto "mais nobre” a família de instrumentos, mais cedo se daria a entrada do instrumentista no conservatório, o que implicaria uma melhor condição financeira da família do jovem músico. Assim, os primeiros, mais nobres e, conseqüentemente, de melhor condição social seriam os músicos das cordas, seguidos pelos do sopro e percussão e finalmente, os de pior condição sócio-econômica seriam os instrumentistas da família dos metais, instrumentos que, segundo o autor, demandam menos tempo de estudo e possibilitam uma inserção mais rápida no mercado.

Tal estrutura não corresponde à realidade das orquestras do projeto aqui analisado, seja pelas diferenças entre França e Brasil, seja pelos diferentes status dos grupos musicais em questão. Mesmo para se pensar algo semelhante com relação às orquestras profissionais do país seria preciso uma pesquisa que ainda inexiste. No entanto, a percepção de Lehmann com relação ao vínculo entre características do instrumento ou família de instrumentos e aspectos sócio-culturais dos instrumentistas é fundamental para pensarmos a mimese entre fazer musical e vida social e para entender porque a música passa a ser uma dos principais atividades de projetos sociais voltados ao jovem no país. Voltemos, portanto, à metáfora de Alessandra, tentando compreendê-la tendo como base o cotidiano das orquestras do Projeto Guri.

Uma característica fundamental desse cotidiano é o aprendizado em grupos, uma vez que a base pedagógica do Guri é o ensino coletivo. As aulas de 
instrumento ou canto são sempre em grupo. Após algum tempo de aprendizado, a idéia é que os alunos estejam aptos a freqüentar os conjuntos musicais do pólo: orquestras, cameratas, corais.

O ensino musical em grupos não é uma inovação desse projeto. $\mathrm{O}$ maestro Enaldo Oliveira, um dos elaboradores do método do Guri para ensino coletivo de cordas, lembra em sua dissertação que versa sobre essa pedagogia, que a música vocal religiosa caracteriza-se como a primeira experiência de ensino musical de metodologia coletiva. Já as aulas coletivas de instrumentos seriam conhecidas desde as primeiras décadas do século xix.

No século xx, são fundadas várias escolas que questionam o ensino musical tradicional ligado às idéias do "Conservatório", baseado na iniciação musical por meio de aulas de instrumento individuais, ou mesmo do estudo de um ou dois anos de teoria musical antes do contato com algum instrumento. Galindo (2000: 7) relaciona os nomes de Jacques-Dalcroze, Maurice Martenot, Carl Orff, Zontán Kodály, Shinici Suzuki e Edgar Willems dentre os músicos que teriam proposto mudanças no panorama do ensino musical, destacando os trabalhos de Orff e Kodály com relação ao ensino coletivo.

Oliveira lembra que no Brasil a primeira grande tentativa de utilização de métodos coletivos no ensino musical foi também com música vocal, no projeto de Villa Lobos do Canto Orfeônico, durante o Governo Vargas, nos anos 30, como vimos no capítulo 2. Posteriormente, no final da década de 50, José Coelho de Almeida começou a organizar bandas de música em fábricas no interior do Estado de São Paulo. O mesmo professor, na década de 80, no Conservatório de Tatuí, desenvolveu um projeto de iniciação e aprendizado musical coletivo com instrumentos de corda, caracterizado pela "iniciação instrumental coletiva, heterogênea e simultânea" (Oliveira, 1998: 10).

Na década de 70, Alberto Jaffé desenvolveu seu método de ensino coletivo de instrumentos de arco. O Método Jaffé foi aplicado em Fortaleza (sesı, de 1975 a 78), Brasília (Funarte, em 1978) e São Paulo (sesc: 1978 a 1982). Segundo Galindo (2000), atualmente, Jaffé reside nos EuA, mas seu método continua sendo aplicado no Brasil por sua filha Renata Jaffé, com grupos de 
crianças de baixa renda, como no projeto Acorde para as Cordas, patrocinado pelo grupo Pão de Açúcar ${ }^{76}$.

Galindo e Oliveira expõem com detalhes o método Jaffé, deixando clara a influência desse na proposta pedagógica do Projeto Guri, uma vez que ambos os maestros trabalharam na elaboração da pedagogia musical do Guri e desenvolveram seus próprios métodos de ensino coletivo. A proposta de Jaffé para o ensino coletivo de instrumentos de arco tem como objetivo introduzir o quanto antes temas ou fragmentos de obras célebres do repertório erudito, a rápida formação de uma orquestra e o ensino de teoria musical paralelo à aplicação dessa na prática do instrumento. Nas aulas, são ensinados os quatro instrumentos de $\operatorname{arco}^{77}$ simultaneamente. As aulas em grupo são indicadas até que os alunos adquiram a técnica básica do instrumento. O estudo é dirigido: o professor controla o estudo, a velocidade de execução dos exercícios, a quantidade de repetições do exercício. É fundamental que o professor percorra a sala tocando no corpo dos alunos a fim de detectar e eliminar tensões musculares nocivas; tal orientação é a já citada "assistência manual”. O professor é orientado a conduzir a aula de maneira semelhante à regência de uma orquestra. Tal pedagogia não visaria a formação de solistas, mas de instrumentistas de orquestra.

Oliveira afirma como vantagens do aprendizado em grupo o estímulo ao desenvolvimento do aluno e a diminuição no tempo de aprendizado da técnica básica do instrumento. "Para a maioria dos iniciantes, as primeiras tentativas de produção do som nos instrumentos de corda são extremamente desagradáveis se ouvidas individualmente. Entretanto, se executados em um grande conjunto, esses sons tornam-se bastante aceitáveis devido à fusão das sonoridades. O êxito inicial gera, no aluno, uma dose de satisfação pessoal bastante elevada, estimulando-o a continuar o aprendizado" (idem: 20).

\section{entre a estética e a ética}

As análises dos maestros Enaldo Oliveira e João Maurício Galindo apontam para as vantagens do ponto de vista pedagógico e estético do aprendizado coletivo. 
A observação da prática musical no Projeto Guri revela também algumas peculiaridades do método com relação à sociabilidade do público ao qual o projeto se destina. Nas aulas em grupo e na prática orquestral, há horários a serem respeitados, rituais que devem ser cumpridos, hierarquias conhecidas. Há rotina, regularidade, planejamento. Em virtude do contato freqüente e duradouro, os hábitos, desejos e estados - de corpo e espírito - dos colegas são conhecidos. A convivência não se restringe às aulas, ensaios e apresentações: os jovens estudam juntos, saem juntos, vão à mesma igreja, namoram. A prática em grupo resulta, portanto, em um compartilhar de valores e tempo, que em muito remete à convivência familiar.

A percepção de Alessandra, que encontra "famílias" em cada novo pólo, tem reverberações em diversos níveis. Regina Kinjo, professora e regente do pólo Mazzaropi e ex-professora do pólo Febem, conta a experiência de ser tomada como "mãe" por seus alunos:

\section{P: Quais as principais carências dos meninos [internados na Febem]?}

Regina Kinjo: A principal carência é falta de compreensão de alguém, que podia ser mãe, pai, irmão, amigo de algum lugar. Geralmente eles não tinham quem os ouvisse. Se você os chamava pelo nome - José de tal -, já ficava feliz, porque dificilmente alguém era chamado pelo nome. Então, quando a gente chamava, já era motivo de respeito, sabiam que podiam confiar um pouco mais. No começo, eles ficavam vigiando o quanto podiam confiar, o que podiam perguntar, o que podiam fazer. Com o tempo - cinco, seis meses - estavam contando coisa de família para o professor, sem a gente perguntar. Porque quando entramos lá, eles [funcionários da Febem] falam: "não pergunte nada, coisa pessoal, não pergunte”. E era o que a gente fazia. Mas acho que eles chegavam numa confiança tamanha que começavam a contar sobre a vida, sobre as dificuldades, e procuravam apoio dessa forma. Então eles não tinham amigos, para conversar, trocar idéia, perguntar sobre a vida lá fora. Essa ausência de carinho e compreensão... 
P:Vocês acabavam por suprir esse espaço?

$\mathrm{R}$ : De uma forma pequena, mas muita gente me chamava de mãe.

P: Como foi isso para você?

R: Fora da Febem, quando os alunos me chamam de mãe, eu falo que não gosto. Na Febem, para mim era complicado. Porque eles estavam precisando de uma mãe. Tinha pelo menos uns cinco que me chamavam de mãe. No começo foi complicado, depois fui me acostumando. E eram os que mais trocavam idéias e confidências os que me chamavam assim.

É preciso ressaltar alguns detalhes para se ter a dimensão do significado de ser chamada de "mãe" pelos jovens internos na Febem. Primeiramente, a internação é, basicamente, a retirada do jovem da sua rede de relações, que inclui o convívio cotidiano com a família. Tal rompimento o coloca em uma posição de isolamento com relação à sociedade como um todo ${ }^{78}$. Por um período, ele está recluso, retirado do fluxo dos acontecimentos da vida social. Independentemente da qualidade da relação que o jovem tinha com seus familiares - próxima ou distante, boa ou má - o momento da internação colocará essa relação em suspensão. Isto pode gerar, por um lado, uma reflexão acerca da própria família: o que significava, qual era seu papel, o que poderia ser transformado nas relações familiares. Por outro, a ausência do convívio - bom ou não - com os familiares, associado ao modelo de relações imposto pela instituição gera um vazio relacional: a "carência" de que fala Regina.

O ambiente institucional não é minimamente acolhedor. Nos funcionários da Febem - sobretudo os monitores, os mais próximos dos jovens - dificilmente o interno encontra disposição para uma aproximação, uma conversa, e, ainda menos, alguma expressão de carinho. Sua função é manter a ordem, dar instruções, vigiar e punir. Nesse espaço, a disposição para ensinar, ouvir e - até!! - tocar é sem dúvida supervalorizada. Acompanhando as aulas de Regina, observando sua voz suave reinar em uma sala com muitos jovens de voz em mutação, algumas já bastante graves, não é difícil imaginá-la como a mãe, de quem se es- 
pera amor, compreensão, mas também alguma cobrança, disciplina.

Na situação de internação, o professor de música é também um importante elo de ligação entre o jovem interno e o "mundão". Paula Miraglia descreve a expressão "mundão" como a categoria nativa que define o mundo de fora, em oposição ao mundo de dentro da instituição. "Mundão" serve para definir papéis (quem é de dentro e quem é de fora) e acontecimentos anteriores à internação ("fiz isso no mundão"). A idéia de "mundão", um mundo grande, enorme, pode ser contraposta à idéia do mundo pequeno que é o institucional. "Nesse sentido, muitas vezes quando fazem referência ao mundão, os internos estão, na verdade, falando do conjunto de expectativas relativas à desinternação, assim como do presente que deixa de ser vivido fora dos muros da instituição" (Miraglia, 2001: 125). Dentre os elementos de comunicação entre a Febem e o "mundão", Paula cita as visitas, os jovens que têm permissão para sair - como os participantes do Guri que se apresentam fora da instituição - e as "pessoas do mundão", ou seja todas as que não são funcionárias da Febem, mas que atuam na instituição. Dentre essas, estão voluntários que promovem atividades, pesquisadores como Paula e eu, e os professores do Guri.

Observei, com freqüência, a aula de música configurar-se como espaço de transmissão de valores. Além de música, falava-se da vida cotidiana de alunos e professores, de seus planos e crenças. O professor era, freqüentemente, tomado como modelo pelo aluno. Muitas vezes, ele se colocava, propositadamente, nessa posição. Presenciei mais de um professor utilizando exemplos de sua vida pessoal para estimular e sugerir caminhos para os jovens internos na Febem. Nos discursos desses professores, a música surge sempre como o elemento que os guiou na direção "certa”, que os ajudou a evitar o caminho "errado”, já trilhado pelos jovens.

aula de violão / Febem Tatuapé

No fim da aula, o professor, sem muita cerimônia, perguntou aos alunos

- quase todos novos - em “qual código eles foram enquadrados". A conversa correu solta. A maior parte se identificou como $157^{79}$, assalto a mão armada. 
A turma citou também um "homicídio", apontando o suposto autor, que não se pronunciou. O professor procurou então aproximar sua experiência de vida da dos garotos. Disse que se não soubesse escolher as companhias certas, provavelmente estaria também na Febem ou no Carandiru.

A aula que anotei no caderno de campo explicita outra possibilidade de comunicação entre professor e alunos na situação de internação. Era a primeira aula de violão de vários dos jovens presentes na sala e, contrariamente à recomendação institucional de não se falar dos motivos da internação, era, justamente, a infração que os levou até lá, o mote da conversa ${ }^{80}$. Ao observar que esse também era o tema preferido das primeiras conversas e apresentações de nossos alunos nas oficinas de vídeo ${ }^{81}$, Paula Miraglia notou que o "crime vinculado à história pessoal” era um assunto central, mesmo na ausência de um questionamento ou de um estímulo para tal temática. Paula argumenta então que a narração insistente do envolvimento com o crime pode ser vista como uma "tentativa de reivindicar um lugar ou uma identidade individual, num espaço onde só há lugar para o status que caracteriza o grupo" (idem: 133).

As aulas do projeto Guri e nossas oficinas de vídeo tinham algumas características comuns. Os professores eram pessoas do "mundão", sem vínculo com a Febem. Não eram cursos "profissionalizantes". Eram atividades mistas, com jovens de mais de uma unidade. Eram portanto momentos privilegiados para o exercício dessa "identidade individual": a narrativa do crime como parte da história de vida podia ser ouvida, nessas aulas, por jovens de outras unidades, por gente do "mundão". As próprias atividades pedagógicas (o vídeo, a música) poderiam vir a individualizar as identidades em construção dos jovens, mas era sem dúvida o crime o elemento diacrítico eleito pela maioria dos meninos como sua marca pessoal, sua impressão digital.

Apesar de valorizada "dentro" da Febem, a associação com o crime é o estigma do jovem no "mundão", ao menos na parte deste que exclui o crime do rol das atividades desejáveis. Tal estigma era constantemente lembrado pelos professores, que, por outro lado, estimulavam o contato do jovem com o mundão, 
por meio das apresentações, como uma possibilidade de reverter a imagem que a sociedade tem dele. "O pessoal lá fora tem uma idéia de que aqui dentro só tem gente que não sabe fazer nada. [...] Isso aqui [o Guri] não é passatempo. Vocês não estão aqui para um cantar para o outro. Vocês são dignos. Não é cachorro, que a gente está adestrando. Por isso vão fazer um bom trabalho e ir para fora [se apresentar]".

A frase de Márcio, regente do coral do Guri na Febem, é rica em imagens acerca do "mundão", e da forma como a sociedade enxerga o jovem interno. Informa ao jovem que "o pessoal lá de fora" os enxerga como ignorantes e inúteis ("gente que não sabe fazer nada”), e que a música expressa o inverso disso, sua “dignidade”. Márcio também diferencia o fazer musical (o "bom trabalho") do "passatempo", procurando tirar da prática coral o caráter ocupacional de outras atividades, ou de mero "lazer" ${ }^{\text {". }}$. Em síntese, o professor traz ao grupo imagens do "mundão" e dos tipos de pensamentos que são formulados nesse "mundão" acerca deles, os “de dentro". Em geral, o que se destaca na fala do professor é o estereótipo negativo que a sociedade constrói do jovem interno e a prática musical como possibilidade de desconstrução dessa imagem.

"Vocês têm que ir lá para mostrar que são gente. Porque vocês sabem que lá, no mundão, as pessoas não pensam assim...”. A frase de Chiquinho, funcionário da Febem que atuava na "casa” onde aconteciam as aulas do Guri, é tão chocante quanto cotidiana - e ainda mais chocante porque cotidiana. É repetida por professores e jovens, num triste coral. O jovem expressa sua mágoa, com raiva: "tem muita pessoa que vê a gente como animal, não vê a gente como ser humano. Porque nós roubamos, erramos, tudo bem. Mas não, eles criticam”. Os professores insistem em que a música é uma forma de "mostrar que são gente", "que têm talento", que "são bons no que estão fazendo". Mais uma vez observamos a expressão da dicotomia. Aqui a música é apresentada como contraponto à animalidade, pretende devolver ao jovem uma humanidade que lhes é retirada quando da internação.

A observação de outros pólos do Guri revela que esse modelo de relação - que extrapola a aprendizagem e atinge outros planos da vida do aluno e do 
professor - é recorrente no projeto. Na Febem, a relação afetiva, a troca de confidências e experiências pessoais, o espelhamento entre aluno e professor é somente mais visível e intenso em virtude da ausência de outros relacionamentos sociais dada pela situação de internação. Em geral, o professor de música que é contratado pelo Projeto Guri sabe que não irá somente ensinar música, mas, como lembra o maestro no início deste capítulo, irá conversar, dar atenção e trocar experiências com crianças e jovens que nem sempre "ouviram um bom dia ao sair de casa".

\section{A casa, o pátio, meninos e marmanjos - etnografia da aula na Febem}

Durante minha observação na Febem, além de alguns professores do Guri, duas mulheres assumiam um lugar privilegiado no contato com os jovens. Rose e Elza eram funcionárias da Febem na área de Projetos Especiais, voltada às atividades lúdicas e pedagógicas para os internos. Sua proximidade e afetividade com os jovens justificava plenamente que eles chamassem de "casa” o local onde conviviam por algumas horas por semana com as duas e com professores do projeto Guri. Foi por meio de Rose e Elza que comecei a conhecer a Febem, o Guri na Febem, e algo muito diferente do que via no noticiário ou mesmo nos livros sobre a instituição: seus "meninos".

Era dessa maneira que Rose e Elza se referiam aos jovens internos. Denominação carinhosa e política, que mima e devolve, no plano da linguagem, a condição infantil que lhes é retirada no momento da internação, quando não muito antes, pela vida mesmo. Considero relevante que tal relação de proximidade e afetividade - quase familiar - se dê justamente no espaço da prática musical. Esse espaço é, por isso, distinto radicalmente de outros espaços cotidianos, o que é significativo no caso da Febem. Proponho uma visita à prática musical nessa instituição com dois intuitos: observar a relação entre tal prática e a situação de privação de liberdade e refletir acerca dos sentidos do fazer musical como intervenção social a partir de um caso limite. 
Despir-se da rotina institucional. Assim pode ser descrito o processo da saída para a aula de música, que tem início com o percurso entre a Unidade Educacional (uE) e o local da aula. Para chegar à “casa”, os internos saíam de suas unidades acompanhados por dois ou três monitores, e andavam em filas não muito "indianas" (às vezes vários caminhavam lado a lado), geralmente conversando. Não observei, nas turmas que se encaminhavam ao Guri, a postura exigida pela instituição em outros momentos de circulação interna - chegada à unidade, visita a algum órgão para atividade burocrática - caracterizada por mãos para trás, cabeça baixa, andar ritmado.

"Acho que até o próprio fato deles saírem da unidade e caminharem até o local do Projeto Guri já é um meio de gostarem disso”. A fala do monitor da UE 7, que abrigava os internos mais jovens (de até 14 anos) do Tatuapé, lembra que tudo é redimensionado quando se está do outro lado dos muros. Por isso, entendo os momentos que antecedem a aula ou ensaio como parte integrante da atividade. Fazer música na Febem era, para começar, passar pelo portão da unidade, caminhar uns 300 metros, no caso da U.E. 7, passar pelo campo de futebol, observar a movimentação, chegar à "casa".

A entrada da casa era um local peculiar, dada a circulação relativamente livre, se comparada aos outros espaços da Febem. Do lado de fora, era comum encontrar grupos de internos em pé ou sentados, fumando, conversando ou quietos, observando, várias vezes sem monitores por perto. A "sala de visitas" ${ }^{33}$ era um espaço de convivência de funcionários, monitores e internos, com regras distintas dos demais espaços compartilhados pelos mesmos. Lá, observei gestos improváveis em outros espaços: a recepção calorosa de jovens por Rose e Elza, com abraços, beijos, sorrisos. Nesse espaço, também fui cumprimentada de forma diferente, com apertos de mão como os que eles trocavam entre si, sorrisos e a saudação: "e aí, senhora, tudo bem?", na qual a espontaneidade do "e aí, tudo bem?" até suavizava o peso do "senhora", expressão de interlocução obrigatória na Febem.

A “casa” era também espaço privilegiado de fofoca. O Guri era um dos poucos locais nos quais, em um mesmo dia, encontravam-se internos de diferentes 
unidades. Na "sala de visitas" ou nos corredores entre as salas de aula, os jovens trocavam informações sobre o paradeiro de colegas (desinternados ou transferidos de unidades), sobre acontecimentos do cotidiano, sobre o "mundão".

A chegada ao Guri era, portanto, marcada pela imersão em outra espacialidade. Durante a estada na "casa" do Guri, parte das regras institucionais eram suspensas, sobretudo as que se dirigiam à atitude dos internos. Talvez por isso não devesse causar estranhamento na "casa" os internos serem "meninos", para Rose e Elza, para os professores de música, para mim.

A relação dos jovens da Febem com esse espaço foi bastante explorada na ocasião da primeira grande rebelião de $1999^{84}$, que chamara a atenção por ter sido a maior desde a de $1992^{85}$. A imprensa noticiou e a Secretaria de Cultura, por meio de seu então secretário Marcos Mendonça, ressaltava, em apresentações ou em entrevistas, o fato dos instrumentos musicais, que ficam no interior da casa dos Projetos Especiais, terem sido preservados em meio à rebelião na qual vários prédios da Febem foram destruídos, a pau e fogo. A relação dos jovens com o espaço ganhou, com esse episódio, caráter mítico: é recontada e relembrada em vários contextos, geralmente para atestar a eficácia do Projeto Guri na criação de uma relação de vínculo, respeito e valorização entre os jovens e os promotores da atividade musical.

“Tivemos um episódio triste na Febem, uma rebelião; mas os garotos que participavam do Projeto Guri naquela unidade da Febem guardaram seus instrumentos num determinado local, trancaram esse local para evitar que esses instrumentos fossem depredados, e que eles não pudessem mais fazer parte da orquestra do projeto". Dessa forma, o então Secretário de Cultura, Marcos Mendonça, narrava o evento em questão. Essa fala, pronunciada na apresentação do concerto de inauguração da sede da Sociedade Amigos do Projeto Guri, na Sala São Paulo, no segundo semestre de 2000, pude ouvir em mais de uma ocasião pública.

Em 5 de junho de 2000, ao noticiar o Guri como o vencedor do prêmio Multicultural do Estadão, o jornal publica reportagem que destaca o episódio da rebelião: "um dos melhores exemplos da força do projeto Guri é o pólo da Fe- 
bem. Segundo o Secretário da Cultura, desde o início das atividades, em 1996, a unidade que abriga o projeto teve as fugas reduzidas em $42 \%$. Na última rebelião o único local preservado pelos internos foi onde os instrumentos musicais estão guardados" $"$.

A nota da coluna social do jornal O Estado de S. Paulo, de 29/10/99, é um exemplo da construção do mito, além de rica em representações da sociedade acerca do universo da internação:

\begin{abstract}
"Um dado interessante sobre a Febem. No primeiro tumulto que houve na Febem do Tatuapé, as crianças atendidas pelo Projeto Guri, da Secretaria de Estado da Cultura, saíram correndo para esconder seus instrumentos num quarto, que foi um dos raros espaços que resultaram ilesos da confusão que se seguiu. Estas crianças não queriam que se estragasse a única chance de vida em sociedade que lhes tem sido oferecida. [...] Estamos falando de crianças. Para marmanjo que pega em armas, assalta, estupra e mata, o lugar não é a Febem. A única solução é a cadeia. E não importa a idade.”
\end{abstract}

Cesar Giobbi (colunista social do Estadão, em sua coluna "Persona")

O colunista elogia, sob o pretexto do evento, o projeto que dá "a única chance de vida em sociedade" às "crianças" que correram para salvar seus instrumentos. Mas em seguida alerta que está falando das “crianças”, não dos “marmanjos” que "pegam em armas, estupram e matam”. O jornalista poderia ignorar o fato da Febem atender prioritariamente os "marmanjos", e que mesmo as crianças - sem aspas - que lá estão, em sua maioria, "pegam em armas". Giobbi faz vistas grossas ao fato de que o lugar para os "marmanjos que pegam em armas" - e prioritariamente para estes, já que para delitos menores o recomendável é a Liberdade Assistida ou prestação de serviços para a comunidade - é sim a Febem, segundo a nossa Constituição e o Estatuto da Criança e do Adolescente, e que projetos de arte-educação, de re-inserção social ou de lazer são prescritos por lei para esses mesmos "marmanjos", uma vez que a lei brasileira entende que o menor de 18 anos tem direito a um tratamento especial que lhe permita a reintegração social 
quando da saída da instituição. É claro que a lei ainda está longe de ser cumprida, mas, para uma parcela da sociedade nacional - representada de forma exemplar pelo pensamento do colunista social - há crianças e há marmanjos, e com estes últimos o Estado não deveria gastar seu tempo, nem seus instrumentos musicais.

Passados quatro anos da publicação dessa coluna social, seu discurso mostra-se mais atual que nunca. Seu eco pode ser ouvido no recente movimento pela redução da idade penal, que ganhou força com a comoção social provocada pelo assassinato de dois estudantes de classe média (Felipe Caffé, de 19 anos, e Liana Friedenbach, de 16) no início de novembro de 2003, por “Champinha”, que não tinha idade para ser preso. Além da movimentação pela redução da idade penal, propostas estão sendo encaminhadas pelo governador Geraldo Alckmin para ampliar a punição de menores envolvidos em crimes graves. Um projeto levado à Câmara dos Deputados estabelece que o prazo máximo de internação passe de três para oito anos, e que os internos que completem 18 anos possam ser transferidos para um presídio!

Outra versão sobre o episódio da preservação dos instrumentos foi narrada por Rose, coordenadora de Projetos Especiais na área de Artes da Febem e uma das responsáveis pelas atividades da "casa", nos seguintes termos: "Os meninos ocuparam a casa, escolheram-na como abrigo. Não roubaram Tv, vídeo, CD. Não destruíram a casa". Na fala de Rose, o espaço da prática musical é investido de valores do universo doméstico: é chamado de casa, é visto como abrigo, oferece proteção, é cuidado, não destruído. Rose e Elza passaram a noite da rebelião nesse espaço com dezenas de jovens. Questionei-as se tinham sentido medo. Disseram que não, salvo por vários dos meninos estarem drogados: "tomaram droga, xarope, solvente. Isso deu medo". O fato das duas serem funcionárias da Febem há muitos anos - Rose, em 1999, contabilizava 14 anos de casa - pode justificar a calma com a qual enfrentaram a situação. Para mim, só o fato de saber do ocorrido e as advertências de que a qualquer momento poderia começar outra rebelião eram suficientes para um estado de alerta e uma sensação constante de medo. Apesar disso, posso afirmar que compartilho a sensação de abrigo desse espaço: na casa, sempre me senti menos "em risco" do que em outros espaços, 
como os corredores entre unidades, a biblioteca onde ministrava com Paula Miraglia as oficinas de vídeo. Parte dessa sensação de segurança advinha, no entanto, da presença de Rose, Elza e do Chiquinho, funcionários que pareciam ter controle sobre a situação e, principalmente, respeito e carinho pelos jovens que por lá passavam. A convivência na casa sugere que o respeito mútuo, o carinho e a realização de atividades gratificantes e belas no espaço constituem a justificativa para a proteção aos que nela se abrigaram - inclusive os instrumentos.

Mas as versões da mídia, dos funcionários, da Secretaria de Cultura não dão conta da totalidade do evento. O fato é que os instrumentos foram realmente preservados. Mas as paredes não. Após a primeira onda de rebeliões lembro de ter-me surpreendido com a nova decoração da sala de visitas. Uma pintura em tons de azul e branco, estilo "celestial”, acabara de ser realizada por Chiquinho, funcionário da Febem na área de Projetos Especiais. Ao elogiá-la, entendi que tinha uma função mais que decorativa. Visava apagar os vestígios da rebelião (pichações, sujeira).

A dicotomia céu x inferno, sugerida pela pintura de Chiquinho, é recorrente nos diversos discursos sobre o universo da internação. Na coluna de Giobbi, revela-se nas oposições entre crianças e marmanjos, instrumentistas e estupradores. No mito da "casa” preservada - e mito aqui não é sinônimo de falso -, nas versões de diversos atores sociais (Secretário de Cultura, funcionários da Febem e mídia), a oposição se dá entre ordem x caos, associados ao espaço musical x espaço da violência.

"Comecei o Guri para fugir do pátio". Na frase ouvida muitas vezes, a versão dos jovens: a música se opõe ao pátio. O pátio é o local da Unidade Educacional no qual os internos passam a maior parte do "tempo livre", ou seja, no qual não estão na escola, na faxina, em alguma atividade (simbolicamente) remunerada ou se alimentando, por exemplo. É a "fuga do pátio" a principal justificativa para a procura por qualquer atividade "extra", seja um curso profissionalizante, seja o aprendizado do violino. O "pátio" é sinônimo da rotina institucionalizada, do 
máximo controle institucional, de estar "fazendo nada", de só ficar "pensando besteira" - o que inclui, quase sempre, fugir ${ }^{87}$.

Mas o que é a música? "Comecei a tocar só para sair da unidade, mas agora eu estou gostando mesmo”. Ilustro essa outra frase, comum entre os participantes do Guri na Febem, com momentos de aulas na instituição.

ensaio de violino - Febem Tatuapé

Há um mês o grupo de 15 a 20 alunos estuda com o mesmo professor violino e viola das $8 \mathrm{~h} 30$ às $12 \mathrm{~h} 00$ todos os dias. São de Unidades fechadas e só saem para o Guri (o ensino obrigatório, fundamental ou médio, se dá na própria uE). No intervalo (às $10 \mathrm{~h}$ ), tomam sol, trocam palavras, sérios. Na volta do intervalo, a maioria se ocupa em tocar as músicas que estão escritas (na lousa, nos papéis), afinar, trocar corda. Mesmo antes de começar a aula, todos estão fazendo música (!).

O professor toca (para quem?) a "Primavera", de Vivaldi. Um garoto comenta com outro: "é a música da propaganda”. Alguns imitam os gestos do professor. Sérios.

Na segunda parte da aula, passam algumas músicas. Estão se preparando para uma apresentação. A aula se aproxima do fim. O professor já está guardando partituras, mas vários jovens continuam empunhando seus instrumentos. Discutem detalhes de uma música, executam ainda uma vez um trecho da melodia, trocam anotações, copiam notas em folhas de papel. A aula já acabou, mas alguns continuam fazendo música.

O trecho do caderno de campo evidencia meu espanto diante de um grupo de mais de 10 adolescentes iniciantes em um instrumento de orquestra, que consegue manter a concentração e o interesse após horas de aula. Professores experientes costumam dizer que nessa faixa etária - e na condição de iniciante - um jovem dificilmente mantém a concentração após 30 minutos. O que observei em diversas aulas do Guri - de instrumentos, de canto - não seria possível caso os 
alunos não estivessem realmente gostando do curso.

Após algumas aulas, para a maioria dos jovens, a fuga do pátio já não era a justificativa para estar no Guri. Os garotos estavam realmente fazendo música - e vivendo alguns dos vários significados que esse fazer implica: sentimento de conjunto, concentração, cooperação, comunicação, superação de dificuldades, autoconfiança, auto-estima, prazer.

aula de coral - Febem Tatuapé

Cerca de 10 alunos. Começam em pé, é hora do relaxamento. Alguns alunos comentam que acordaram quebrados. Justificam a reclamação com uma descrição da rotina da unidade. Márcio, o professor, coordena uma automassagem. "Por que tem que massagear?", perguntam. "Para relaxar. Para cantar é importante estar relaxado". Com gestos ainda duros, tocam-se.

A rotina descrita inclui, por vezes, dormir na "cela", ficar "na tranca" ${ }^{8}$. A violência física e psicológica é recorrente, seja entre iguais (os próprios internos) ou desiguais (funcionários e internos). O controle sobre os internos é exercido em várias instâncias, sendo o corpo seu alvo mais evidente. Por meio de restrições às movimentações (ficar em pé ou sentado não são gestos de livre escolha), de controle das necessidades fisiológicas (ir ao banheiro requer autorização), exerce-se uma ação sobre corpo e alma dos internados (Foucault, 1988). Como na análise de Franco Basaglia sobre instituições fechadas psiquiátricas, o interno é levado a aderir "a um novo corpo que é, na realidade, o da instituição". Isso se dá ao ter negado "cada desejo, cada ação e cada aspiração autônomos que fariam com que se sentisse ainda vivo e ainda ele próprio” (Basaglia, 1985: 121).

Dois minutos de massagem não são suficientes para transformar corpos vigiados, mas, necessários para retirá-los do "lugar de passagem" em que são colocados na internação. Na definição de Basaglia, o corpo do internado é "um corpo indefeso, deslocado como um objeto de um para outro pavilhão" (idem: 122). A aula de música exigirá desse corpo uma nova postura. Ele precisará produzir sons, vibrar, encontrar-se com outros corpos e sons, ser e fazer o belo. Corpos 
tensos não produzem sons bonitos. É físico. Um ombro tenso não permite que o peso do próprio braço que segura o arco exerça sobre a corda do instrumento a pressão necessária para a produção de uma nota sonora, forte, límpida. "Soltar a voz" implica relaxar músculos faciais, lubrificar cordas vocais, respirar fundo e deixar o ar fluir. Implica também se soltar, esquecer, por momentos, qualquer vigilância: não pensar que se está sendo visto, julgado, analisado.

aula de coral - pólo Mazzaropi

Uma das primeiras aulas do ano. Regina, professora-regente, estava classificando as vozes. Observava quem mudou de voz, pedindo que cantassem.

A classe, ainda um pouco tímida, era estimulada por meio de comentários como: "não tenha vergonha", "solta a franga". Regina despertava risos, a classe ia "se soltando".

A aula de um outro pólo - esse, de jovens que nunca passaram pela situação institucional de restrição de liberdade - é chamada para exemplificar o processo pelo qual passa o corpo para tornar-se musical. O canto implica uma grande auto-exposição. $\mathrm{Na}$ aula em questão, ao cantar o jovem evidenciava sua maturidade, seu próprio ciclo de vida. Um rapaz de 13 anos ruborizou ao ser identificado numa posição intermediária: a voz ora grave ora aguda não permitia que Regina lhe confiasse um lugar definido no coro. Soltar a voz implica, portanto, soltar-se, perder a vergonha, exibir o corpo, exibir-se todo.

O fazer musical, portanto, não é redutível à descrição simplista que opõe música e violência, bem e mal. A relação entre prática musical e a situação de internação é sobretudo conflituosa. Parte do conflito pode ser entendido pela própria inserção do projeto de ensino musical na estrutura da Febem. Apesar das determinações do ECA da oferta de atividades de lazer e arte-educação para jovens em situação de internação, na Febem, apenas a escola (ensino fundamental ou médio) é obrigatória. A participação nos demais cursos depende da indicação da direção de cada uk, que determina quais adolescentes poderão freqüentar as atividades, conforme avaliação de conduta e histórico individuais. Os internos 
que "causam problemas" na unidade (brigam, participam de tentativas de fuga, ou enfrentam funcionários) dificilmente participam dos cursos. Qualquer comportamento considerado indevido pode "retirar" os jovens das atividades. Assim, as atividades do Projeto Guri acabam por reproduzir um sistema de castigos e privilégios - o bom comportamento é premiado com a participação no projeto ${ }^{89}$ - reforçando a estrutura repressora institucional.

Por outro lado, aqueles que têm acesso à prática musical experimentam uma efetiva interrupção no cotidiano institucional. A música desperta desejos. Isto é fundamental para superar situações de baixa auto-estima, como a estimulada pelo ambiente das instituições totais (Goffman, 1974), ou mesmo em situações de carência material ou emocional. O educador Cesare de La Rocca, criador do Projeto Axé, vê a possibilidade de recuperação da auto-estima justamente por meio de uma "pedagogia do desejo", que trabalhe o indivíduo para que ele tenha o desejo de ter desejos (apud Dimenstein, 1998).

O fazer musical, lembra Lévi-Strauss (1991: 35), pega "pelas entranhas", age "sobre o espírito e sobre os sentidos", move “idéias e emoções”. Ou seja, instaura desejo, gera sentimento e reflexão, produz conhecimento. A cobra morde o rabo. A reflexão é - como deve ser - mãe da crítica e autocrítica, o que implica, muitas vezes, contestação, descontentamento, revolta. Apesar das manchetes de jornal venderem a imagem de jovens "pacificados" pela música ("Arte faz fuga da Febem diminuir 41\%") $)^{90}$, presenciei jovens despertados pelo fazer musical, jovens que percebiam suas potencialidades e as limitações decorrentes de sua situação, seja de preso, seja de pobre. Jovens que percebiam o prazer decorrente da produção de sons, de música, mas sabiam que dificilmente teriam acesso a esse prazer do outro lado dos muros. E o aluno que fala para o professor "quando sair daqui quero roubar um contrabaixo" é a expressão da explosão da dicotomia, um retrato da contradição. 


\section{Entre a ética e a estética?}

Um senso comum entre a coordenação do Guri é que o projeto não tem como objetivo formar músicos, mas mudar a vida das crianças e jovens participantes. Assim, é o papel social do ensino musical que é destacado. Mas, algumas conquistas estéticas são evidentes. As apresentações que reúnem alunos de vários pólos e músicos de renome como Toquinho ou Celine Imbert em locais como a Sala São Paulo são os exemplos mais visíveis. Também testemunhei belas experiências nas salas de aula da Febem, do pólo Mazzaropi ou do POF. Encontrei ex-alunos do Guri na Escola Municipal de Música, onde estudei violoncelo. Para esses, a profissionalização como músico já era uma perspectiva bastante realizável.

Essas observações visam questionar a separação das esferas ética e estética, presente na proposição de projetos como o Guri ${ }^{91}$. Para começar, é difícil separar qualquer aprendizado musical da busca do belo. Mesmo na execução de uma simples corda solta, em sua primeira aula de violino, o aluno deverá buscar o som mais bonito que conseguir produzir. Essa busca implica uma apuração dos sentidos; o "belo", neste caso, está no "sonoro", "limpo", "constante”, ora "forte” ora "suave", "vibrante”. Ao ser capaz de buscar na execução musical mais simples o belo, o jovem poderá entender melhor a música produzida pelo virtuose; aos poucos, compreenderá as diversas camadas de sentidos e sensações contidas na composição musical.

O formato escolhido pelo Guri, que privilegia a apresentação pública do conhecimento adquirido, também coloca em evidência a discussão das esferas ética e estética. Nas performances públicas, os músicos são apresentados como crianças e jovens carentes que estão tendo uma oportunidade, recuperando sua auto-estima etc ${ }^{92}$. Já os jovens percebem-se como músicos, afirmando inclusive a vontade de se profissionalizar. Nas duas formas de descrever o mesmo grupo, duas medidas: uma que se atém à questão ética, o potencial da prática musical como forma de intervenção social; a outra, na fala da jovem para quem é destinada a intervenção, o desejo de ter reconhecido seu potencial estético.

Entre os propositores de métodos para ensino musical coletivo uma preo- 
cupação comum é a formação de músicos para orquestras e de um público capaz usufruir o prazer estético advindo da escuta musical. A separação entre música, cultura e política não é tão evidente. Compositores como Zóltan Kódaly - e Villa Lobos, no caso brasileiro, como analisado - viram na educação musical uma forma de difundir valores nacionais. Um dos principais defensores e propositores do ensino musical desde a infância, Kódaly pregou o conhecimento musical universal, "incluindo a habilidade da leitura e escrita”. Para Kódaly, apenas ouvir música não era o bastante, "sendo necessário fazer música para poder entendê-la e conseqüentemente, apreciá-la” (in Galindo, 2000:21). Previu, para tal, a importância da rede escolar do país. "Atualmente o sistema de educação húngaro começa na pré-escola, com alunos a partir de três anos de idade, em atividades lúdicas, como jogos musicais, nas quais são utilizadas peças folclóricas ou compostas especialmente para crianças. O curso primário é de oito anos, sendo que, nos últimos quatro, os alunos passam a ser orientados por um professor de música, em geral duas vezes por semana. Por volta de 160 escolas primárias operam nas bases propostas por Kodály”, descreve Galindo (idem: 25).

Shinici Susuki, autor de um dos mais divulgados métodos de ensino de instrumentos de corda para crianças, também vê de forma ampla o alcance do aprendizado musical: "alguns poderão tornar-se solistas, outros poderão tocar apenas para seu próprio prazer ou aprender a desfrutar melhor de uma execução musical” (in Galindo, idem: 28). Vários músicos e pedagogos musicais concordam com essa idéia.

“Assim, à pergunta 'para quem serve o ensino em grupo' eu diria: para todos. Para aquele que será apenas um amante da música, para aquele talento que poderá tornar-se um profissional e para o talento excepcional, que poderá vir a ser um solista. [...] Serve igualmente a muitos jovens de baixa condição sócioeconômica, para quem tornar-se músico é efetivamente uma ascensão na escala social”. Diante dessas observações, o maestro Galindo se pergunta: "Não seria o caso de se pensar em alguma maneira de transplantar este trabalho para a rede oficial?" (Galindo, idem: 177/8).

Alessandra, que reivindica o direito a ser ouvida como musicista - o di- 
reito à apreciação estética - é também paradigmática quanto à total imbricação entre as duas esferas. Após uns cinco anos no projeto Guri, onde hoje é também funcionária de pólo, Alessandra responde sem pensar à minha pergunta sobre mudanças em sua perspectiva de vida depois de fazer música: "Sim. Você quer, você batalha e consegue. Isso em relação a tudo". Quem a vê cuidando dos papéis do pólo ou na primeira estante dos violinos nos ensaios e apresentações da orquestras do Guri entende imediatamente o que ela quer dizer. 


\title{
IV. ETNOGRAFIA DA PERFORMANCE
}

\section{[MÚSICA, IDENTIDADE E TRANSFORMAÇÃO]}

\author{
Vocês têm que ir lá para mostrar que são gente. Porque vocês \\ sabem que lá, no mundão, as pessoas não pensam assim... \\ Chiquinho, na época, monitor da Febem-Tatuapé \\ que acompanhava as atividades do Projeto Guri
}

O convite deixou-me eufórica. Luciana, a professora com quem aprendia cello havia um ano, me chamava para tocar com a orquestra do Mazzaropi no Teatro Cultura Artística - "vai ser algum evento do Marcos Mendonça"ł3. Era a oportunidade de um contato único com o grupo que começava a pesquisar. Seria minha primeira apresentação. Estrear no Cultura Artística...

28 de setembro de 1998. Teatro Cultura Artística, São Paulo. Um dos principais palcos da música erudita na capital. A orquestra do Mazzaropi - o mais antigo pólo do Projeto Guri, inaugurado em 1995 - foi convidada a tocar antes da principal atração da noite, a Academy of ancient music, uma orquestra inglesa de música antiga. A presença de jovens músicos não profissionais na tradicional temporada de concertos internacionais promovida pela Sociedade de Cultura Artística é algo, se não inédito, bastante incomum.

No camarim improvisado - os oficiais estavam reservados para a Academy - sons e cheiros se sobrepõem, inundando os sentidos, inundando de sentidos... A afinação dos instrumentos é simultânea ao lanche, à maquiagem, à troca de roupas. Tanta gente (grande e pequena), tantos timbres, tanto pão, maçã e coca cola. Atmosfera efervescente.

O ensaio no palco contou com uma audiência maior que a de outras apre- 
sentações por mim assistidas. Além dos professores de instrumentos - que acompanham às vezes as turmas nas apresentações - estavam na platéia algumas das coordenadoras do Projeto Guri, a maestrina responsável pela parte pedagógica do Projeto, algumas mães. O repertório da apresentação foi introduzido pelo maestro da orquestra à coordenação do Guri. Enquanto os alunos passavam as músicas, a coordenação do projeto selecionava as que seriam tocadas no concerto.

Não pude ensaiar, um dos cellos quebrou e os reservas ainda não estavam no teatro. Sentei em um canto para tentar ler - pela primeira vez! - a partitura que tocaria em alguns minutos. Alguns dos jovens se aproximaram um pouco surpresos: "a senhora sabe tocar?". Minutos antes eu lhes perguntava sobre os sentidos do fazer musical. Só então, no canto improvisado para o estudo, revelava o saber compartilhado. Eles trocaram olhares.

A platéia, com 1.156 lugares, tem poucas cadeiras vagas. Marcos Mendonça, então secretário de Cultura do Estado de São Paulo, apresenta a atração que abrirá o concerto da noite:

"Estão neste palco meninos e meninas que, por meio da música, descobriram que podem fazer algo bom. São crianças e jovens carentes, internos da Febem, que estão recuperando sua auto-estima ao aprender um instrumento, tocar em uma orquestra. Soubemos, por exemplo, que diminuiu o número

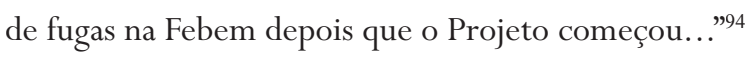

Olhei para a Alessandra (a spalla), para o Valdir (o concertino ${ }^{95}$ ), para outras crianças e jovens que conheci no pólo e nos ensaios. Postura e expressão facial inalteradas, ao ouvir as palavras do apresentador. Como estariam se sentindo sendo identificados - pela indiferenciação - com "internos da Febem" ou "menores carentes"? Eu, que ocupava a cadeira reservada ao segundo violoncelo sem nunca ter ensaiado de fato com a orquestra, senti-me duplamente intrusa. Nem membro da orquestra, nem criança, nem carente, nem da Febem... Mas algo nos olhares dos meus colegas de palco indicava que eu não era a única a não se enxergar na imagem que o apresentador projetava sobre nós. 
Os aplausos que acompanham a entrada do maestro são a deixa para a interrupção da fala e dos demais pensamentos. A música tem que começar.

Dois compassos mudos, desenhados com a batuta do maestro, antecedem o primeiro ataque. Então, o ar inspirado profundamente é liberado de uma só vez, e a expiração vira som. Sopro que perpassa oboés, flautas, clarinetes... Impulso que faz deslizar a crina sobre as cordas de violinos, violas, cellos... Um e dois e Um e dois e... O ritmo inescapável, estranhamente, suspende a temporalidade ditada por relógios e calendários. Durante os 30 compassos, esqueceremos os minutos, horas, dias. Agora há pouco, alguém desejou "merda!". Poderia ter dito "boa sorte", mas sabe que essas são palavras indizíveis na coxia do teatro. Um e dois e Um e dois e... O maestro sorri. Fortíssimo: sol, doooo. Aplausos. Teatro cheio. Nos olhamos. Todos sorriem. Vontade de rir. Felicidade...

A narrativa - interrupta, subjetiva, emocional - reproduz alguns flashes que povoam a memória - confusa, física, visceral - da experiência de tocar com um dos grupos que pesquiso. Foi, simultaneamente, minha primeira audição pública e, do ponto de vista antropológico, algo correspondente à fuga da polícia durante a briga de galos, descrita por Clifford Geertz (1989) ${ }^{96}$. Seria um exagero dizer que a relação que eu mantinha com o grupo se caracterizava pela invisibilidade. Mas havia em nossas conversas uma distância, ora marcada pela desconfiança com relação às minhas intenções, ora pela dificuldade de transpor para o plano verbal as sensações advindas da prática musical. Não penso que minhas intenções tenham ficado claras para a maioria dos jovens, mas, com certeza, passamos a nos ouvir de outra maneira após aquela noite.

A apresentação de fragmentos de uma apresentação compartilhada com os jovens que pesquiso também tem como objetivo a inserção do leitor no universo da performance. Experiência ampla, a performance é central em projetos que, como o Guri, tem como um dos objetivos principais a intervenção social por meio da música. Ela torna visíveis atores e instituição. É palco de um amplo jogo de 
espelhos, lugar de exibição de identidade e construção de auto-imagens. É espaço de transformação. É concebida como auge do processo pedagógico, locus de exibição do que foi aprendido, ensaiado, incorporado. É oportunidade de conhecer novos lugares, pessoas, é “saída para o mundo”, frase que ganha ainda mais intensidade quando pronunciada por quem foi retirado da convivência social.

Performance is an illusion of an illusion and, as such, might be considered more 'truthful', more 'real' than ordinary experience

Richard Schechner, Performance theory

O estudo da performance é, hoje, uma das possibilidades dos trabalhos em etnomusicologia. Tiago de Oliveira Pinto (2001: 227) descreve a "etnografia da performance musical" como a passagem da análise das estruturas sonoras à "análise do processo musical e suas especificidades". Nesse tipo de abordagem, o pesquisador não pensa a música enquanto "produto”, mas “como 'processo' de significado social, capaz de gerar estruturas que vão além dos seus aspectos meramente sonoros". A ênfase no processo pode ser traduzida na frase que JeffTiton (1992) usa para definir a etnomusicologia: "the study of people making music".

Richard Schechner comenta em prefácio uma das últimas obras de Victor Turner, The anthropology of performance: "Acho que ele estava tão interessado em performance porque performance é a arte que é aberta, interminada, descentralizada, liminar. Performance é um paradigma do processo" (in Turner, 1987: 8; trad. e itálicos meus). Cabe lembrar que a perspectiva processual era o foco de Victor Turner desde a década de 1960, quando, a partir de Van Velsen (1967) o antropólogo começa a desenvolver análises (Turner: 1970, 1974, 1974b) que enfatizam a dinâmica da vida social.

Em From ritual to theatre, Turner defende a "antropologia da perfomance" como parte essencial de uma "antropologia da experiência": "todo tipo de performance cultural, incluindo ritual, cerimônia, carnaval, teatro e poesia, é explicação da vida” (1982: 13; trad. minha). Recorrendo à etimologia da palavra - performance deriva do francês antigo parfournir, completar - Turner atribui 
à performance o momento de finalização de uma experiência, sem o qual esta não se completa.

Schechner, parceiro de Turner em trabalhos sobre a Antropologia da Performance, defende sua diferença com relação ao autor do conceito de drama social. Turner localizaria o drama essencial no conflito e na resolução desse. Schechner (1988) localiza-o na "transformação": em como as pessoas usam o teatro como um meio de experimentar, atuar e sancionar mudanças. As transformações via performance se dão tanto nos performers (que re-arranjam seu corpo e mente) como no público. Nesse, as mudanças podem ser temporárias (e aqui se está falando da performance como entretenimento) ou permanentes (no caso do ritual).

Cabe notar que o trânsito entre entretenimento (teatro) e ritual é fluido. Schechner lembra que quando a performance tem como propósito efetivar transformações - "ser eficaz" - outras qualidades (como transe, participação da audiência, ausência de crítica) estarão presentes e a performance será, de fato, um ritual. Por outro lado, considera que quando o teatro pretende gerar atos eficazes a performance está sendo também ritualizada. A diferença básica entre teatro e ritual estaria na separação entre espectadores e performance, que caracteriza o primeiro. Mas, as fronteiras não são rígidas: "In all entertainment there is some efficacy and in all ritual there is some theater" (Schechner, 1988: 138).

A teoria antropológica da performance ajuda a analisar o fenômeno aqui estudado. Pensar a performance implica não isolar esferas da vida social como estética, ética, política, religião etc. Schechner (1995) conta que em sua experiência de estudos de rituais indianos foi questionado sobre seu desejo de conversão para o hinduísmo: “Seus motivos são religiosos ou estéticos?". Após refletir, percebeu que não fazia sentido a divisão sugerida na questão: "Como podemos separar os dois, especialmente na Índia?”. Ao analisar a prática musical no Guri é preciso considerar as transformações que pode operar em seus praticantes e no público. Ao atuar na construção do corpo, a música pode transformar de forma permanente seus praticantes. Também o público que assiste às apresentações pode passar por alguns níveis de transformação. Se for próximo do jovem (mãe, 
irmãos, tio, amigo), acompanhará mais de perto a transformação do performer e será afetado por esta. Se distante, será convidado a observar a transformação operada pela música em seus praticantes e, ao menos durante a performance, será levado a refletir sobre aquela condição e a sentir os efeitos da música produzida.

No Guri, a performance é o centro do projeto pedagógico. O contato do aluno com o instrumento é imediato: uma vez inscrito no Projeto, o aluno escolhe - ou lhe é sugerido - o instrumento que quer aprender e esse lhe é apresentado já na primeira aula. Em pouco tempo, os alunos já sabem tocar algumas músicas - de repertório erudito e/ou popular - com arranjos simplificados. A idéia é que em até dois meses o aluno já possua um repertório mínimo para participar, com a orquestra do pólo, de apresentações externas.

É preciso contextualizar tal proposta pedagógica. O aprendizado de um instrumento de orquestra é geralmente entendido, seja por músicos, pedagogos ou leigos, como "difícil". É associado à disponibilidade de dedicação, tempo, concentração, persistência. Os resultados não são imediatos. Um estudante pode passar semanas ou meses "incomodando seus vizinhos" até conseguir "tirar" do instrumento um som minimamente agradável. Sem perder de vista essas características do aprendizado musical em questão, o projeto pedagógico do Guri, tal como analisado no capítulo 3, procura explorar algumas peculiaridades da prática musical em grupo para diminuir os efeitos de desânimo e desistência em virtude das dificuldades colocadas.

$\mathrm{O}$ acesso imediato ao instrumento em aulas e ensaios coletivos - dos quais podem participar de dois a quinze, vinte alunos - é um dos principais estímulos aos jovens iniciantes. Muitos dos alunos justificam ter procurado o Projeto Guri justamente pela possibilidade de acesso rápido ao instrumento, diferentemente do que ocorre nas escolas de igrejas das quais muitos são participantes. Nessas, o ensino de teoria musical precede a prática de instrumento. É comum o aluno só vir a ter contato com o instrumento após dois anos de estudos teóricos.

A perspectiva de uma apresentação em curto prazo é extremamente estimulante para os alunos do projeto. A possibilidade de tocar para uma platéia 
- composta de familiares, amigos, estranhos e, às vezes, com cobertura da mídia - anima os aprendizes. Jovens que sabem tocar quatro ou cinco notas em um instrumento podem ser vistos ensaiando durante horas, discutindo as músicas e a técnica instrumental entre si, alterando o cotidiano da família para participar de apresentações nos mais diversos horários.

Esse quadro também é bastante diferente do aprendizado musical tradicional, seja em conservatórios ou em escolas de igrejas. Nesses locais, uma vez iniciado o estudo do instrumento, o aluno só virá a tocar em uma orquestra (de estudantes, de fiéis) após alguns anos de estudo.

Alunos, professores e coordenadores do Guri enfatizam a apresentação como "combustível” (a "expectativa” e "ânimo” de Cecília) e "culminância” ("Campos de Jordão!”) de um processo pedagógico.

"Saber desde a primeira vez que já tem apresentação, aquilo te traz uma expectativa, você já começa a se animar. Você percebe a evolução a cada dia... Ir para Campos de Jordão! Ninguém esperava com seis meses de coral ir para um festival...”

Cecília, 18, estuda violino e canto há dois anos no Mazzaropi

“A apresentação é o combustível da orquestra. Quando fica muito tempo sem apresentação, a orquestra murcha. Se ensaia, ensaia, ensaia e nunca toca, fica meio sem sentido.”

Valter Batista de Azevedo, Asa, maestro da orquestra do pólo Mazzaropi

“Tem um processo até culminar na apresentação. Tem criança ansiosa, depressiva, com problema de relacionamento, e lá você não pode ter problema com nada, porque você vai canalizar tudo para a música, pro seu instrumento, pro seu colega. Você tem que aprender a respeitar o seu colega, tem que ir devagar, esperar o outro tocar, saber a hora que você entra. Concentração...” Silvana Cardoso, coordenadora técnica do Projeto Guri 
No caso do pólo Mazzaropi, a própria espacialidade local reforça a participação dos alunos nos grupos musicais. Simultaneamente às aulas, acontecem os ensaios de vários grupos: a orquestra, uma camerata de cordas, uma de violões, os corais. Todos os alunos acabam “passando” pelos ensaios: o auditório - no qual ensaiam orquestra, camerata de cordas e coral - é também uma passagem entre a entrada principal do espaço cultural Amácio Mazzaropi e entrada secundária, onde estão as salas de aula do Projeto Guri. A porta do auditório nem sempre está fechada, e é comum ver alunos que não participam dos conjuntos sentados na platéia assistindo aos ensaios. A "aura” do palco italiano, cerca de um metro mais alto que a platéia e iluminado com holofotes, é, sem dúvida, mais um dos atrativos para o jovem estudante desse pólo.

Tanto as aulas em grupo como a participação em algum dos conjuntos (orquestra, coral, camerata) reforçam uma das características essenciais do projeto em questão: a experiência do coletivo. Para fazer música junto com várias outras pessoas, é preciso "respeitar o colega, esperar o outro tocar, saber a hora de entrar", como lembra Silvana Cardoso, coordenadora técnica do Guri. Isso cria uma espécie de união entre os participantes. Eles são identificados como um grupo - e precisam pensar essa identidade. São, sobretudo, interdependentes.

Tais características são bastante contrastivas com a experiência individualizante do aprendizado musical, por exemplo, em um conservatório, no qual a principal relação é entre aluno e professor. Nesse caso, é valorizado o estudo individual, solitário, que deve resultar no desenvolvimento da técnica do instrumentista.

Maestro Asa: Eu desenvolvo a parte da prática de orquestra, porque tocar individualmente é uma coisa, em orquestra é diferente. Saber tocar em naipe, saber ouvir o colega é diferente de ser apenas um solista.

Pergunto: Que tipo de habilidade a prática de orquestra exige do músico?

Asa: aprender a ouvir a orquestra, aprender a ouvir tudo, aprender a ouvir o arranjo, qual a função dele em determinado trecho da música.

P: E essa habilidade, que é musical, você acha que se transfere para a vida das pessoas? 
Asa: Acredito que sim, porque a música exige muita disciplina, senão você não sai do lugar. Tem que praticar todos os dias, nem que seja pouco, porque é a coisa constante que faz andar. Dá sentido de cooperativismo, porque você não toca sozinho na orquestra, você faz parte de um monte de coisas que estão acontecendo, então existe uma cooperação da sua parte para o todo da sonoridade da orquestra.

Asa, maestro da orquestra do pólo Mazzaropi

\section{Ampliação de horizontes}

No capítulo dois, mostrei a importância atribuída à "recuperação da auto-estima" no discurso dos proponentes de projetos, e o lugar privilegiado atribuído à performance para alcançar tal objetivo. Questionei, naquele capítulo, a própria idéia de resgate de auto-estima, uma vez que o discurso que afirma tal necessidade termina por criar uma representação de baixa auto-estima que seria comum a todos os participantes dos projetos, o que não corresponde, por sua vez, à realidade.

É inegável que a performance pública do conhecimento adquirido mexa com o performer. Suas habilidades estão sendo exibidas para um público amplo, que pode incluir seus familiares, que até então só tinham ouvido tímidos ensaios individuais. Ao levar a público seu conhecimento musical, o jovem está "indo lá e mostrando que é capaz”. Para alguns, é a oportunidade de "mostrar que é gente”, e não animal...

Sem ignorar as transformações que a performance efetua nos performers de forma individual, gostaria de percebê-la aqui, como Turner, como "finalização de uma experiência”, que, no caso do Guri, poderia ser, predominantemente, a experiência da coletividade. A prática em conjunto favorece a criação de vínculos afetivos entre os participantes e acentua redes de sociabilidade. A dinâmica das apresentações contribui para a ampliação do horizonte social do jovem, sugere o exercício da alteridade - por exemplo, no encontro com grupos sociais diversos 
- e resulta na aquisição de habilidades e vivências que destacam o jovem em seu grupo de origem.

Em uma análise de programas governamentais de educação esportiva para jovens e crianças, postos em prática nos anos 80, Alba Zaluar (1994: 65) destaca o fato de criarem "um espaço real de encontro entre as pessoas", resultando na "ampliação do horizonte social dos jovens que acabam saindo do círculo familiar mais estreito, da rede de vizinhos mais próxima, da rua ou praça para o bairro, ou seja, redes de sociabilidade que vão integrá-los à cidade”. Zaluar destaca, além da prática das aulas - que ampliam o horizonte da rua para o bairro - as competições, nas quais os jovens esportistas podem até sair de sua cidade. A autora conclui que a participação em círculos cada vez mais amplos de pessoas "tem por efeito romper o paroquialismo na sua excessiva identificação com um só local ou uma só categoria de pessoas", dissolvendo "mecanismos que mais comumente conduzem à violência”.

A possibilidade de conhecer pessoas com experiências de vida diversas das suas dá aos jovens referências, opções: aponta caminhos, acertos e erros, possibilidades. Ouvi de vários jovens que antes de entrar no Guri não tinham projetos, sonhos. Com a participação no projeto - seja por seu envolvimento com a música, seja por conhecer pessoas que tomavam como exemplo - passaram a fazer planos, vislumbrar possibilidades.

Os participantes de alguns pólos do Projeto Guri se apresentam em vários locais distantes do seu pedaço (Magnani, 1992): hotéis como o "Morrafej” (na confusão cacofônica de um dos garotos da Febem, que se referia ao Hotel Sheraton Mofarrej, em São Paulo, no qual a orquestra de internos apresentouse), cidades como Campos do Jordão (onde acontece o Festival de Inverno, no qual o Guri apresenta-se todos os anos, juntamente com músicos profissionais, como Antônio Nóbrega e Toquinho), e teatros como o do Memorial da América Latina.

As saídas para apresentações são consideradas por coordenadores, professores e alunos o ponto alto do projeto. A observação revela que as saídas possibilitam o contato com diferentes espaços e públicos, além do encontro entre 
jovens participantes de diversos pólos. Essas três dimensões devem ser levadas em consideração.

\title{
o outro no palco
}

\author{
"Os ensaios aproximaram muito os pólos. A realidade de cada pólo é muito \\ diferente. Um viu a realidade do outro." \\ Ângela Visconti, supervisora técnica do Guri
}

Uma das formas de apresentação do Projeto Guri é a que reúne jovens de diversos pólos, na formação de orquestras e corais mistos. Isso se dá principalmente em eventos de grande porte, quando os conjuntos podem se apresentar com artistas convidados. A interação entre participantes de pólos diferentes não é intensa. Os membros de cada pólo tendem a se fechar nos seus grupos de origem. Eventualmente, ocorrem alguns contatos fora do palco: apresentações, conversas rápidas, brincadeiras entre os mais jovens, uma ajuda para se arrumar no camarim.

Apesar da convivência ser curta e da tendência à "endogamia", é muito forte a troca de impressões sobre o outro. Ângela tem razão ao afirmar que um $v \hat{e}$ a realidade do outro. Eles se percebem: observam os jeitos, as roupas, as diferenças, e até a habilidade musical do grupo estranho. O encontro pode ser alegre ou conflituoso, como mostrarei na descrição da apresentação em Campos de Jordão, que uniu jovens dos pólos Mazzaropi e Febem.

A coordenação ${ }^{97}$ avalia positivamente a relação que se estabelece no encontro entre grupos de diferentes pólos e realidades sociais:

"Fizemos uma apresentação para montar o pólo da São Remo, onde as crianças são extremamente carentes, baixa renda mesmo. Nós levamos [o pólo de] Taubaté para tocar e eles fizeram uma apresentação com teatro junto, sobre os 100 anos do nascimento de Monteiro Lobato, o Sítio do Pica Pau Amarelo. Acabada a apresentação - que eles curtiram demais -, os pequenos ficaram 
desesperados de tanta alegria, por terem visto a Emília, o Pedrinho, a Narizinho. No final, as crianças foram vestidas dos personagens cumprimentar as crianças da favela. Parecia show da rede Globo... Para eles, eram artistas. O grande lance é que as crianças de Taubaté não se sentiram nem um pouco superiores, pelo contrário. Entre eles não existe esse estigma: 'ele é filho de traficante'. Isso é coisa entre nós, adultos.”

“A gente sentiu respeito entre eles. Por exemplo, no pólo do POF, da favela, as crianças são extremamente humildes, diferente de Indaiatuba, onde o nível das crianças é um pouco melhor. Mas eles participaram da mesma mesa de refeição, do mesmo banheiro para se trocar, usaram o mesmo uniforme. Isso é resgate da auto-estima: ele estar se sentindo igual perante o público, o evento, a gente."

Ângela Maria Visconti, supervisora técnica do Guri

Em alguns depoimentos de alunos do projeto também está presente essa valorização do encontro com o outro. Marcos, 18 anos, que estudava saxofone no pólo Mazzaropi havia três meses, destacou de sua viagem a Campos de Jordão o fato de ter conhecido o "pessoal da São Remo”. Lembrou da história de um garoto da São Remo que contou que roubava e parou "por causa do Guri”. Falou também de um jovem estudante do pólo de Indaiatuba que já estava dando aula. Para Marcos, "é legal ter exemplos assim".

Mas o encontro - ou sua possibilidade - também é um convite ao conflito, como fica evidente na fala do jovem interno que se sente discriminado pelo "boyzinho" de outro pólo ("nós viemos aqui para cantar, não para ser esculachado”). Neste outro depoimento, é o jovem do pólo Febem - na época, em destaque dadas as constantes rebeliões - que surge no imaginário dos pais de um pólo aberto em toda sua ambigüidade:

Converso com um grupo de duas mães e um pai, que me pergunta se aqui no Mazzaropi tem gente da Febem. "Uma mãe falou que ia tirar o filho por causa 
disso. Mas e se tiver? E daí? Não é tudo gente? Eu não vou tirar, mas acho que não tem. A gente vê. Teve apresentação. Veio tudo com pai e mãe trabalhador, os filhos bem vestidos...”

Trecho do caderno de campo, pólo Mazzaropi

\section{o outro na platéia}

O encontro com o outro não se limita ao palco e coxias. A performance implica e depende da presença do outro na platéia. É o público um dos principais espelhos do jovem participante do Guri. A apresentação é, por um lado, a vitrine que exibe o projeto e seus atores, fixando sua identidade. Por outro, é uma oportunidade ímpar de manipulação de auto-imagens ${ }^{98}$, dada a diversidade do próprio público, formado por familiares, amigos, conhecidos, desconhecidos - a maioria -, gente de diversas classes sociais, jornalistas e suas câmeras (fotográficas ou - o mais esperado - "da televisão").

O conceito de "jogo de espelhos”, de Sylvia Caiuby Novaes, descreve com precisão um dos mecanismos postos em prática na performance.

\footnotetext{
"Quando uma sociedade focaliza um outro segmento populacional, ela simultaneamente constitui uma imagem de si própria, a partir da forma como se percebe aos olhos deste outro segmento. É como se o olhar transformasse o outro em um espelho, a partir do qual aquele que olha pudesse enxergar a si próprio. Cada outro, cada segmento populacional, é um espelho diferente, que reflete imagens diferentes entre si.” (Caiuby Novaes, 1993: 107)
}

Para a performance, são mobilizadas expectativas, representações de si (do indivíduo e do grupo) e do outro (o público, que pode conter mães, amigos, parentes, estranhos, "gente filmando").

Na sala de entrada da casa do Guri, aonde esperávamos a partida do ônibus, dois meninos estavam acompanhados de suas mães. Elas vieram para a festa 
junina da Unidade e souberam que os filhos iam sair para uma apresentação, não ficariam na festa. Usavam chinelos e uma delas estava com a filha, de uns oito anos. Ao se despedir, beijou o filho e disse a ele para ir lá e fazer bonito: "mostra o que você sabe", "aproveita a oportunidade”.

Trecho do caderno de campo, Febem-Tatuapé, julho de 1999

“Sorriam para o público, sejam simpáticos, agradeçam. Ali é um lugar sagrado, não dá para conversar com o mano, bater papo... Em respeito ao pessoal que tá lá, tem um monte de gente filmando, de todos os lados, mantenham a postura... Vocês só estão aqui porque são bons. Tem que soar um coral de homem, não de menino...”.

Instruções de Márcio Damazo, regente do coral do Guri na Febem-Tatuapé, momentos antes de subirem ao palco no Festival de Inverno de Campos de Jordão, em julho de 1999

O principal mecanismo de fixação de identidade durante uma performance é a apresentação do projeto, que antecede o número musical. Antes da orquestra e coral começarem a tocar, um apresentador descreve as principais características do projeto e seu público alvo. Em geral são destacados: o órgão que criou e mantém o projeto (a Secretaria de Estado da Cultura), o projeto ("oferecer o ensino de instrumentos de orquestra e canto a grupos de crianças e jovens que dificilmente teriam acesso ao mesmo, dada sua condição social”) e seus objetivos e metas alcançadas ("propiciar oportunidades para os jovens, através da música, de desenvolver sua auto-estima, o gosto pelo conhecimento, e através da convivência, poderem se identificar como cidadãos, ocupando espaços sociais e culturais na comunidade" ${ }^{\prime 99}$ ).

Tal mecanismo de identificação do grupo é fundamental à própria dinâmica da performance. O público que assiste a uma apresentação do Guri será - dada tal identificação - essencialmente diferente. Seu objetivo não será - como o da maioria das platéias de orquestras e corais profissionais - a fruição pura e simples do espetáculo. Seu critério não será estético apenas, mas sobretudo ético. O belo 
fica em segundo plano diante do que é necessariamente "bom": recuperar crianças em situação de risco, oferecer oportunidades a quem não as possui, educar para a cidadania, entre outros objetivos declarados na apresentação do projeto.

Se, por um lado, a apresentação tende a fixar a identidade do grupo e direcionar a expectativa da platéia, por outro, as formas como os jovens se vêem e sentem são bastante diversas. Os jovens da Orquestra Paulista Juvenil do Projeto Guri, formada pelos alunos mais avançados dos pólos, comentaram, certa vez, que estavam contentes porque pararam de ser apresentados como "carentes" ou "infratores". Queriam ser apresentados como jovens que estão aprendendo música, como uma orquestra jovem. Queriam ser reconhecidos pela qualidade da música que tocavam e não por serem "de baixa renda" ou por terem "recuperado a auto-estima” no Projeto Guri. Uma mãe de aluna do Pólo Mazzaropi comentou que sua filha estava cansada de ser identificada como "da Febem". "Um dia, estávamos no camarim do teatro e uma funcionária falou: tão bonitinha, nem parece da Febem. Isso chateia muito ela”. A rigidez - por vezes, confusão ${ }^{100}$ - da definição (identidade atribuída) os atinge (desagrada à maioria) e os leva a produzir outras imagens de si. As falas mostram facetas dessas imagens: são ora "profissionais", “artistas”, ora apenas afirmam o que não gostariam de ser.

P: Qual a imagem que o público tem de vocês? Quem vocês acham que eles pensam que vocês são?

R: Acho que eles pensam que nós somos adolescentes querendo aprender e seguir, e acho que eles sentem o que a gente tenta passar.

P: Quem vocês são? Como você gostaria de ser apresentada?

R: Como um grupo de adolescentes que querem mesmo ser músicos de qualquer forma, a qualquer preço.

Alessandra , 18, spalla do Mazzaropi

P: Como você se sente estando aqui na Sala São Paulo?

$\mathrm{R}$ : Me sinto como se eu estivesse na televisão.

P: O que você pretende preparar para o futuro? 
R: Ir tocando ou cantando para a televisão.

Gabriela, 9, aluna de violão no Mazzaropi, entrevistada por colega do pólo

"É bom, distrai. Sempre que a gente chega, a gente é bem vindo em um lugar. A gente se sente à vontade. Não tem maldade, não tem preconceito... não tem preconceito: é ladrão...”

Resposta de interno da Febem à pergunta de uma repórter do Estado de $\mathrm{S}$. Paulo sobre a importância da música

"Ih, estragou! Tinha que falar Febem?"

Reação dos jovens do coral do pólo Febem à fala do apresentador no Memo-

rial da América Latina

A última fala evidencia que o próprio jovem interno tem a exata noção do estigma que carrega a identificação com a instituição. A reação descrita foi observada no corredor entre a coxia e o palco do Memorial da América Latina, momentos antes da entrada dos músicos. Bem vestidos e preparados para mostrar o que sabiam cantar e tocar, os jovens ficaram realmente chateados ao serem identificados como internos da Febem. Não puderam experimentar plenamente uma das possibilidades colocadas pela performance: a experiência de tornar-se outro, bastante significativa principalmente no caso desses jovens.

Schechner mostra que uma das possibilidades da performance é essa experiência de transformação. Tornar-se outro não implica abandonar a si próprio. Schechner cita Stanislawski, um dos principais nomes do teatro do século XX, que, apesar de defender um sistemático naturalismo, adverte que o ator não deve se perder no palco, sair de si ("get away from yourself”). Schechner afirma que o performer não deixa de ser ele próprio, mesmo quando possuído por outro ser (como no caso do transe) ou representando um papel no teatro. O performer vive uma situação de liminaridade que o autor traduz como: not himself / not nothimself. Essa possibilidade de viver identidades múltiplas e ambivalentes simultaneamente seria tipicamente humana e uma das propriedades da performance. 
A performance é também uma experiência sensível única, que mobiliza sensações independentemente de estarem sobre o palco amadores, profissionais, estudantes, ou participantes de um projeto de intervenção social. O medo do palco e o frio na barriga são comuns a músicos experientes ou iniciantes, conforme diversos relatos, e por isso podem ser pensados até como constitutivos da experiência da performance. No caso do Guri, seja qual for o do público do dia (muitas vezes formado por desconhecidos), o grupo imagina que há uma expectativa que deve ser atingida. A platéia é sempre ambígua: de lá podem sair os aplausos - reconhecimento do trabalho do grupo - mas também a reprovação. É, portanto, fonte de ansiedade, preocupação, medo, vergonha.

P: Como é ver o público, como vocês se sentem?

R: Às vezes eu olho o público e sinto uma vergonha de errar as notas, de fazer alguma coisa errada, você pode até cair da cadeira, né? Aí fica ruim. (Risos)

P: O que você acha que eles pensam de você?

R: Teve uma vez que eu tava num teatro aí, eu tava tocando, eu tava olhando para minha amiga Natália. Aí a moça pegou e cochichou pro outro homem sei lá o que. Só que eu nem liguei, fiquei lá tocando e ficou tudo jóia.

P:Você se sente importante?

R: Sinto, bem bastante.

Daiane dos Santos Augusto, 11, há três anos estuda violino no pólo Mazzaropi

"[estar no palco com a orquestra:] é uma adrenalina muito grande, mas acostuma. Dá medo de errar, de não entrar no tempo certo.”

Lucibene Santos Silva, 16, estuda percussão há dois meses no pólo da São Remo

"É bom tocar na orquestra porque a gente já vai acostumando. Como amanhã a gente pode tocar em orquestras grandes, já dá uma visão de como é. Fazer apresentação é muito bom porque você já tem o contato com o público, vai 
controlando seus medos, nervosismos e a recompensa de ver que as pessoas estão reconhecendo seu trabalho."

Alessandra, spalla do Mazzaropi

Essa manipulação de expectativas, medos, vaidades e do prazer de fazer música - somente possível dada a relação palco-platéia - corresponde a um intenso aprendizado sentimental ${ }^{101}$. Além do jogo de criação de auto-imagens e manipulação de identidades, há o palco e sua "magia".

Maestro Asa: A gente se sente bastante importante em cima do palco. O palco é uma magia, e a gente estando ao contrário da platéia, é bem gratificante. É um prêmio.

P: $O$ que é essa magia?

Asa: É um negócio indescritível. Não dá para exprimir. É uma coisa que eu realmente sinto. Às vezes eu chego a me emocionar e me arrepiar. Então é uma coisa que não dá para explicar. É uma coisa que vem do âmago mesmo. Asa, maestro da orquestra do pólo Mazzaropi

“[A apresentação] Dá uma emoção muito grande. Não dá para explicar o que a gente sente. A gente sente um prazer, uma emoção muito grande do pessoal estar escutando a música e estar gostando. É uma satisfação grande, imensa. Mesmo quando a gente está mais pra baixo, vai pra uma apresentação e volta mais alegre, mais feliz. A gente vê que o nosso esforço não está sendo em vão, que o público está gostando muito. Fora de estar reunindo os jovens - a maioria da orquestra é jovem. Junta os jovens, a gente fica brincando. É muito gostoso."

Tatiane Miê Hirano, 18, estuda violino no Mazzaropi há três anos

A especificidade do que chamei aprendizado sentimental transparece na dificuldade da verbalização da experiência do palco: "não dá para explicar”, "exprimir”, “é um negócio indescritível”. A "magia” é a categoria nativa que procura dar conta 
do turbilhão de emoções vivido durante a performance. "Prazer", "emoção", "satisfação imensa" que chegam a "arrepiar". No palco, a razão cede à emoção, o fazer musical penetra os poros (“arrepia”) e chega ao "âmago". Por alguns momentos abandona-se o plano da consciência, aproximando-se do universo das vísceras $^{102}$.

A "magia” do palco está também na aura que o envolve. "Ali é um lugar sagrado", o maestro Márcio alerta os meninos do pólo Febem. Para subir no palco é preciso respeitar novas regras ("não dá para conversar com o mano, bater papo”), abandonar características pessoais, vestir uma nova máscara ("sorriam para o público, sejam simpáticos, agradeçam").

No caso dos jovens participantes do Guri no pólo Febem, a possibilidade de experimentar novos personagens no palco ("não eu"/ "não não-eu") é acompanhada pela expectativa do abandono dos estereótipos com que são marcados. Daí, a decepção com a apresentação do Memorial, que os identificava como internos. Estimulados por professores e familiares, os meninos acreditam que a apresentação musical é uma chance de mostrarem que "são gente, não animais", que "erraram, mas estão procurando um novo caminho", que são "capazes”.

"E isso [participar das apresentações] vai favorecendo eles se auto-afirmarem, gostarem de si, do companheiro, do instrumento, da aproximação, da formação do grupo. Aproxima a família, porque os familiares são convidados, todos se emocionam."

Ângela Maria Visconti, supervisora técnica do Guri

"O negócio de cidadania é muito forte na Febem. Então, quando eles eram aplaudidos de pé - e foram muitas vezes -, era um negócio de arrepiar: eles, eu, qualquer um. Tinha gente que levantava, aplaudia e chorava. Aquilo para eles era demais."

Regina Kinjo, regente dos corais dos pólos Febem e Mazzaropi 
A observação revela que de fato a experiência da performance excede os minutos no palco. A performance pode operar transformações permanentes ${ }^{103}$. A magia do palco é incorporada (uma vez que a música age nas vísceras) e carregada para a vida cotidiana dos jovens. As imagens de si construídas no jogo com a platéia, com o apresentador (e com a identidade que sua fala lhes atribui) farão parte das noções de pessoa ainda em construção. É inevitável, após uma apresentação, que se sintam importantes. Muitos passarão a ser respeitados pela família, que assistiu ao concerto ou - ainda mais importante - viu na Tv. Os aplausos e a sensação única que produzem serão munição contra momentos menos felizes, "quando a gente está mais pra baixo", como diz Tatiane.

No entanto, a aura do palco nem sempre ofusca os tons carregados da vida cotidiana. A sacralidade do palco revela-se, muitas vezes, menos marcante que a condição "impura", a "diferença" que marca o jovem interno. A "magia”, nesse caso, pode não acontecer.

"A gente via muito em apresentação. Em sala de aula, eles ficavam a vontade. Chegava em apresentação, isso desmanchava e virava um cubo de gelo. Nem que fizessem graça na frente deles, eles não conseguiam rir. Porque eles sabiam que quem estava vigiando, quer dizer, assistindo à apresentação, era a população normal. Então sabiam que precisavam parecer certinhos, bonitinhos, e transparecer a coisa mais perfeita possível. Eles sabiam que eram diferentes por estar dentro da Febem."

Regina Kinjo, regente

Regina troca palavras. $\mathrm{O}$ ato falho não contradiz sua fala, mas a reforça, de maneira estarrecedora. Revela a inescapabilidade da condição de interno, os limites da superação, pelo palco, do estereótipo do "vagabundo-bandido-animal”. Uma apresentação vigiada contradiz toda a possibilidade de liberdade, subversão e fuga que poderia caracterizar a performance.

"A sociedade, na hora, até pensa: eles têm um certo talento. Mas saindo de lá, eles tratavam da mesma forma. Febem é Febem e vai continuar sendo. 
Isso a gente via no tratamento deles: quando os meninos estavam saindo do palco, todo mundo cumprimentava, parabenizava, e os meninos saiam de lá super cheios, vaidosos. Só que se chamasse alguém do próprio público para conversar com eles, acho que não teria ninguém que iria. Ninguém ia à sala e falava parabéns. Isso acontece no Mazzaropi. Tem gente que vai no fim da apresentação ao local onde estamos e fala 'parabéns, gostei da sua voz'. $\mathrm{Na}$ Febem, enquanto estavam na frente, eram artistas e tinham valor. Só que quando saiam do palco deles, do palco delimitado, viravam Febem de novo, a mesma coisa."

Regina Kinjo, regente

\section{outros espaços}

O terceiro aspecto relacionado à possibilidade de "ampliação de horizontes" colocada pela prática musical no Guri é o contato dos jovens com novos espaços. Há várias categorias de apresentações no Guri. Orquestra e coral podem se apresentar em aberturas de eventos de alguma forma relacionados a atividades da Secretaria de Cultura (como a inauguração de um novo pólo), podem ser convidados para tocar em eventos promovidos por outras entidades (igrejas, os Correios, por ex.) e, por vezes, são a atração musical principal (como na apresentação no auditório Camargo Guarnieri, na usp, ou em vários shows, às vezes com a presença de artistas como Toquinho, parceiro de várias performances) ou secundária, que "abre" um espetáculo, antes da atração principal (como em Campos do Jordão, quando tocaram antes da Orquestra Sinfônica do Estado de São Paulo).

Os exemplos citados apontam para a diversidade e status dos locais onde ocorrem as apresentações. Além dos eventos “caseiros”, que podem ocorrer nos próprios pólos, há apresentações em algumas das principais salas de concerto do Estado de São Paulo. São os mesmos locais freqüentados pelas orquestras profissionais nacionais e estrangeiras que visitam o país. Esse fato, por si, já garante parte de "aura" dos palcos. 
P: Como é para vocês tocar no Memorial?

R: É legal, porque várias pessoas já tocaram aqui, é mais perto da nossa casa, é legal!

Alessandra, spalla do Mazzaropi

Os jovens da orquestra do pólo Mazzaropi, a mais antiga do Guri e com maior experiência de apresentações, já falam com familiaridade de alguns espaços nos quais muitos músicos profissionais ainda sonham em tocar. Para Alessandra, tocar no Memorial da América Latina é "tocar em casa”. Em uma das apresentações do pólo nesse espaço - em comemoração à semana do idoso -, pude observar a intimidade do grupo com o local. Diferentemente da experiência com o pólo Febem, em que cada detalhe - desde a preparação para a saída - é marcado por expectativa e ansiedade, havia entre os jovens do Mazzaropi, mesmo os mais novos na orquestra, um clima calmo, de quase rotina, que só foi quebrado momentos antes de entrar no palco, quando até a spalla, há quatro anos no pólo, confessou ficar um pouco nervosa. No final da apresentação, ouvi na coxia a opinião do grupo sobre sua performance. Para a maioria, a apresentação fora "ruim”, houve desafinações e desencontros de músicos e cantores. O suposto status do local não impediu a avaliação de um dos jovens músicos: "há concertos e apresentações. Hoje foi só uma apresentação”.

A experiência dos jovens do pólo Mazzaropi, que freqüentam várias salas de concerto importantes, os familiariza com um determinado percurso próprio da atividade musical e artística profissional. Esse é um dos fatores que leva muitos desses jovens a vislumbrar uma carreira musical.

P:Vocês se sentem como músicos profissionais?

R: A gente é cobrado profissionalmente, da gente mesmo, e tenta sempre passar o melhor que a gente está aprendendo. Então a gente já se sente como profissional mesmo.

Alessandra, spalla 


\section{P: Como é tocar em apresentações?}

R: Sinto que é um começo para minha carreira, para me tornar um músico. Antes do Guri, eu não sabia como era uma apresentação, se era bom, se era normal. No Guri, estou adquirindo muita experiência. Porque eu tenho até certa vergonha de tocar para um monte de gente. E, aqui no Guri, você começa por baixo e vai subindo, vai para lugares maiores. Tem Campos do Jordão, que é o melhor que tem, e até chegar lá eu já passei por várias apresentações menores e perdi aquele certo medo de tocar.

P: Música é lazer ou profissão?

R: É mais a profissão. Já estou vendo a música futuramente como sendo minha profissão.

P: Sua família apóia?

R: No começo não apoiava. Depois, viram em jornais e na televisão sobre o Guri, e ficaram até alegres, começaram a apoiar.

Marcos Roberto de Araújo, 18 anos, estuda sax no pólo Mazzaropi há 3,5 meses. Toca trompete na igreja há dois anos e sax tenor há um ano.

A fala de Marcos deixa ver outro aspecto do contato do jovem com diversos espaços. As experiências atuam fortemente na educação sentimental do jovem: ele experimenta as sensações do palco em “várias apresentações menores”, perde “aquele medo de tocar”. Na fala do jovem que está há apenas três meses no Guri, já há uma correlação clara entre espaço e importância do evento (há "apresentações menores" e "Campos do Jordão, o melhor que tem”), o que também evidencia a rápida assimilação dos valores do grupo por parte do indivíduo.

Mesmo para aqueles que não têm a perspectiva da profissionalização, a possibilidade de se apresentar nos locais em questão conta também para o reconhecimento, pela família, da importância da atividade musical. A experiência da família de Marcos, que começa a apoiar quando vê o projeto em jornais e na Tv, é recorrente no Guri. A divulgação do projeto na mídia - que acontece sobretudo em virtude de eventos em locais de destaque - é motivo de aceitação da atividade e orgulho por parte dos familiares. 
Se, por um lado, as apresentações permitem o contato dos jovens com espaços densos em significados relacionados à prática musical, por outro, a estrutura das saídas tende a limitar as possibilidades desse contato: pouco se conhece além do próprio palco. Cada apresentação implica a saída do pólo em um ônibus, a chegada ao local do evento, a distribuição do lanche em alguma coxia real ou improvisada, o ensaio no palco, a performance musical e o retorno ao pólo no mesmo ônibus. Há pouco ou nenhum tempo para que os jovens conheçam o local. Daí a importância dada a aspectos aparentemente secundários, como o trajeto, a alimentação e o transporte - que deve ser, segundo alunos e coordenadores, ônibus tipo turismo, com som, confortável etc.

\section{P: Não é só tocar, é conhecer outra realidade?}

R: É conhecer outra realidade. Eles têm o lanche, que é muito importante, tem que caprichar muito. Tudo pode ser ruim, mas se o lanche for bom... O ônibus pode quebrar, mas se o lanche for bom. Se for ruim, eles reclamam, fazem abaixo-assinado. E eles tomam muito lanche. No Pontal [pólo do Pontal do Paranapanema, junto a acampamento dos Sem Terra], nós montamos uma cozinha com cozinheiro, comida. Eles vêm da roça, com o pezinho vermelhinho de terra, sentam e comem.

Nurimar Valsecchi, maestrina e coordenadora técnica do Projeto Guri

P:Você já se apresentou fora daqui?

R: Já, quando eu era da orquestra.

P: Como é fora daqui?

R: É diferente. Eles colocam a gente em lugares bons, às vezes; às vezes, não. Sempre colocam a gente em lugares bons, onde tem cadeira para a gente sentar. Eles dão lanche, eles deixam a gente ir no banheiro, beber água, tudo isso... Tem vez até que... igual quando a gente saiu pra ir na Sala São Paulo: eles deram bis, refrigerante, maçã, sanduíche, em vez de pão e mortadela.

Daiane, 11, estuda violino no Mazzaropi 
No pólo Febem, a limitação do "roteiro" é reforçada dada a própria condição legal do interno. É ambígua a situação de um “passeio” vigiado. É opressora, aos olhos da observadora, uma viagem cuja única paisagem permitida é filtrada pelas janelas do ônibus.

Fui em um ônibus com os "maiores". Sentei-me ao lado de um monitor - o Ferreirinha, que não estava de monitor, mas sim “para passear”. Como ele, foram outras pessoas de fora: a namorada do Chiquinho [outro monitor],por exemplo. Tudo isso dava um caráter de passeio ao evento!

Ferreirinha - um homem franzino com seus quarenta anos - me contou que havia sido interno, ele e outros irmãos (órfãos). Me disse que vários funcionários da Febem haviam passado por lá como menores. Falou que era bom para os meninos terem a oportunidade de sair. Quando chegamos em Campos, comentou que os meninos gostaram de ver as casinhas (casas em estilo europeu) porque eram parecidas com as que eles faziam com palitos. (Havia uma ingenuidade e uma doçura no Ferreirinha...). Os meninos de fato ficaram observando as casinhas: “o que o pessoal vem fazer aqui?”, perguntavam. Mais de uma vez comentei como era linda a cidade, o teatro e o jardim que o cerca. Ingenuidade: eles não puderam ver nada!

Trecho do caderno de campo: descrição do trajeto a Campos de Jordão, onde os jovens do pólo Febem se apresentaram no Festival de Inverno de 1999

Todas as saídas do pólo Febem são acompanhadas por forte escolta policial. Os membros da escolta também vigiam cada passo dos jovens no caminho entre o ônibus e a entrada do teatro ou auditório.

Três ônibus tipo “turismo”, com ar condicionado, som e TV ("que só funciona com fita”) levaram cerca de 50 adolescentes para a cidade do interior paulista, em uma viagem de mais de três horas, acompanhada por uma imponente escolta: policiais do Comando de Operações Especiais, em camburões e motocicletas, armados com metralhadoras e usando coletes à prova de balas 
sobre uniformes de camuflagem.

Trecho do caderno de campo, pólo Febem no Festival de Inverno de 1999

As únicas saídas das coxias improvisadas se dão para o ensaio ou apresentação no palco. Mesmo as idas ao banheiro são controladas pelos monitores.

"Lá, vocês vão ter que se controlar, não dá para ir ao banheiro toda hora, não dá para fumar quando quiser.”

Orientação de monitor aos participantes do pólo Febem do Guri antes de saída para apresentação no Memorial da América Latina

No pólo Febem, as poucas referências ao local da apresentação - o espaço em si - parecem insistir na demarcação da diferença.

“Lá é super fino, super carpete!”

Aqui, a frivolidade e afetação da fala revelam-se quase cruéis dada a situação em que é pronunciada. Na sala de ensaio do Guri na Febem, cerca de 20 jovens são chamados para ouvir as orientações de professores e monitores sobre a saída para apresentação no Memorial da América Latina. É de uma funcionária a descrição que reproduzi. Se retirada de seu contexto a futilidade da frase é cômica, mas, ouvida em cânone com a anterior (“vocês vão ter que se controlar...") e reverberada nos pátios frios da instituição, no cimento liso onde se deve ficar sentado boa parte do dia, ganha tons quase expressionistas.

"Pesa a cadeia, quando penso no mundão... Quando saio, vejo o mundo aqui fora, dá a maior tristeza. Quando eu sair, quero provar que não tinha que estar aqui."

Interno da ue 14 , participante do Guri

“O que vocês gostariam, o que está faltando?”, perguntam os integrantes do 
CEIJ (Conselho de Estado da Infância e Juventude), que visitavam as aulas do Guri na Febem.

- "Mais saídas", respondiam em coro os meninos.

Caderno de campo

As falas reproduzidas colocam a contradição: para os jovens do pólo Febem as saídas são lugar de confronto com o outro, de acareação com os estereótipos que não correspondem às imagens de si. $\mathrm{O}$ contato com o além-muros revela novos espaços e, simultaneamente, a impossibilidade de ocupá-los realmente. Daí a "tristeza" de Fábio. Por outro lado, as saídas são o momento mais esperado, desejado.

"Era o momento mais esperado. Quando tinha apresentação e ele [o jovem interno] sabia um dia antes, ele não dormia a noite, esperando a apresentação. Campos de Jordão foi assim. A emoção de estar indo, estar se apresentando, fazendo alguma coisa boa para alguém...”

Rosemary dos Santos, Projetos Especiais/Febem

A solução para o aparente paradoxo talvez esteja na própria experiência da ambigüidade permitida pela saída e o confronto com o outro: pólo, público ou espaço. A saída é o encontro com a diferença, da qual foram separados no momento da internação. Encontro, no limite, consigo mesmo, dada a relação especular com este outro. A diferença desperta os ânimos - “é tudo filhinho de papai”. A diferença desperta. 


\section{Do pátio ao palco - etnografia de um trajeto}

Encerro este capítulo com a descrição tensa de uma saída do pólo Febem para apresentação no Festival de Inverno de Campos do Jordão, em julho de 1999. No "passeio", que envolve os personagens pelo período de um dia, condensam-se significados acerca da performance. Cabe notar que o pólo Febem era freqüentemente convidado a realizar apresentações em ocasiões de maior repercussão (sobretudo midiática), já que, dentre os pólos do projeto, era o que possuía as características mais exóticas: além de pobres (ou "carentes", para usar a terminologia institucional), eram infratores os adolescentes a quem o projeto oferecia uma "chance de aprender", "recuperar a auto-estima" etc.

Cheguei às $11 \mathrm{~h}$ à Febem. A viagem ia atrasar. Sairíamos por volta das $13 \mathrm{~h}$. Chiquinho, Rose, Elza [funcionários da Febem na área de Projetos Especiais] e os professores do Guri agitavam-se nos preparativos: lanches para os ônibus, espera das listas com autorização dos diretores da unidades (alguns internos que não tiveram a saída autorizada pelo juiz foram liberados pelos diretores das unidades na última hora).

Rose me mostrou as roupas enviadas pela Secretaria de Cultura para os meninos: calças beges e camisetas amarelas, com a inscrição Guri em preto e vermelho. "Parece uniforme de prisão", reclamava. Rose e Elza decidiram vestilos com uniformes de outras apresentações - calça social, camiseta e jaqueta. "Se precisar vestimos estas coisas".

Chiquinho organizava violões, cavaquinhos e percussão. "Você não toca teclado?", me perguntou. O fato é que o professor que tocava teclado - e acompanhava o coral - não pôde ir porque ia se casar: "vamos improvisar”, explicou Chiquinho.

Na sala de entrada da casa do Guri, meninos ouviam de suas mães recomendações para aproveitar a oportunidade, ir lá e fazer bonito. Na mesma sala, outros meninos desviavam o olhar... 
Os ônibus "tipo turismo" estacionaram em frente à casa. Do lado de fora da Febem, aguardava a imponente escolta do Comando de Operações Especiais: camburões e motocicletas, policiais com metralhadoras (cujos modelos seriam nomeados e discutidos com inquietante familiaridade pelos adolescentes), coletes à prova de balas sobre uniformes de camuflagem.

Fui no ônibus dos "maiores"104. Sentei-me ao lado do Ferreirinha e próxima às outras pessoas de fora, como a namorada do Chiquinho. A presença de pessoas estranhas ao ambiente da instituição, ou comuns, mas em papéis diferentes (como o Ferreirinha, que fora "para passear"), contribuía para o caráter extraordinário que assumia o evento: era dia de "passeio". Impressionada por esse clima do ônibus, teci os comentários sobre a beleza da cidade, do teatro e das esculturas do jardim que o cerca. O restante do "passeio" me faria engolir a seco as palavras ingênuas...

Além da escolta, havia uma série de regras - mais ou menos rígidas - que não deixavam esquecer a condição da internação: os jovens deviam ficar sentados, não podiam abrir as janelas (o que acabavam fazendo) nem fumar no ônibus (o que foi efetivamente obedecido, apesar de continuamente questionado). Tais restrições foram reforçadas na chegada ao local da apresentação. Após horas de viagem sem ventilação e sem cigarros (já estavam "fissurados": "três horas e 42 minutos de viagem sem fumar", cronometrava um deles), os jovens tiveram que esperar por mais de meia hora dentro do ônibus, já parado, pela chegada das vans, que fariam o transporte do ônibus ao auditório - localizado a cerca de 500 metros do local no qual estávamos estacionados. A saída dos ônibus em fila indiana, acompanhada de perto por policiais e monitores, em nada remetia à chegada de músicos ao local do concerto.

Entramos pelos fundos do teatro, em uma sala ampla, com várias mesinhas e cadeiras. Lá, todos puderam fumar, jantar as "marmitex" oferecidas pelo Festival, conversar. A cena dos garotos uniformizados (com roupas do Projeto Guri ${ }^{105}$ ), sentados, fumando, comendo e conversando remetia, de forma inquietante, a imagens de refeitórios em presídios. Imagem dialética ${ }^{106}$ - a coxia virava prisão. 
A única saída desse espaço deu-se para o ensaio no palco, em conjunto com a orquestra do pólo Mazzaropi. A coordenação do projeto Guri tinha decidido que apenas o coral da Febem iria se apresentar. A orquestra seria a do Mazzaropi, melhor preparada e com mais tempo de ensaio. Esse fato gerou revolta entre os internos, que já estavam ensaiando há mais de um mês durante quatro horas por dia. (O fato é que o pólo Mazzaropi mantinha a orquestra com basicamente os mesmos integrantes havia mais de dois anos. A instabilidade da situação da Febem dificilmente permitiria algo semelhante - a maioria dos internos estava no Guri havia um ou dois meses). A saída foi levar os internos participantes do coral e da orquestra para o Festival, sendo que os últimos apenas assistiriam à apresentação.

Se as apresentações públicas são, como procurei mostrar, um momento privilegiado de exibição de identidade e construção de auto-imagens, dado o jogo de espelhos entre músicos, platéia e professores, em Campos do Jordão, uma situação de confronto foi o auge desse processo especular. A orquestra do Mazzaropi já estava no palco, quando o coral da Febem entrou para o ensaio geral. Os jovens se posicionaram no local destinado ao coral, no fundo do palco. Alunos dos dois pólos trocaram olhares. O maestro do Mazzaropi deu as coordenadas para o início do ensaio do Hino Nacional. O maestro da Febem posicionou-se em frente ao coral, ou seja, no fundo do palco. Orquestra e coral passaram pela primeira vez a música. O primeiro comentário foi efetuado pelo maestro da orquestra: “tem gente no coral 'miguelando', em referência a alguns dos jovens que não estariam cantando. O maestro Márcio completou: "isso é um coro de homens, não de meninos”, solicitando mais volume e força do coral. Após o hino, a orquestra saiu e o coral pôde ensaiar algumas vezes a música que cantaria sozinho, "Andança”.

De volta ao "refeitório" improvisado, pude notar um clima de revolta entre os jovens. Vários me pediram para ligar a câmera - com a qual eu registrava a viagem - para "dar entrevistas". "O que vocês querem falar?", eu perguntava. Os comentários gerais dirigiam-se à atitude dos "boyzinhos” do Mazzaropi. Minha primeira reação foi a incompreensão. Já conhecia o pessoal do Mazzaropi em 
virtude da pesquisa lá iniciada no fim de 1998. Havia constatado que a maioria se encaixava no perfil definido pela coordenação do Projeto Guri: crianças e adolescentes de baixa renda, moradores, em geral, dos bairros da periferia de São Paulo. Questionei os garotos da Febem sobre o sentido da categoria "boyzinho": "é tudo filhinho de papai”, respondeu-me um deles. Insisti: "Mas tem boyzinho na periferia?”. E a resposta era certeira: "não!”. "Eles ficaram fazendo xiiiiiii. Eles acham que só eles sabem tocar. Mas a gente também sabe”, falavam indignados para a minha câmera perplexa.

O que os teria levado a identificar o grupo do Mazzaropi de tal forma? A posteriori, é possível elencar uma série de fatores: a revolta com o fato da orquestra da Febem ter sido excluída da apresentação - manifesta inclusive em um abaixo assinado encaminhado anteriormente à Secretaria de Cultura - continuava latente, e, no palco, evidenciou-se o principal "rival" que os "tirou de campo"; o grupo "rival" é formado, na maioria, por jovens que compartilham com os internos a mesma faixa etária, o mesmo tipo de conhecimento musical, mas possuem um diferencial primordial: a liberdade. Se, por um lado, sua aparência física e comportamento não seriam elementos suficientes para defini-los como pobres ou ricos, sua condição privilegiada (não estão presos, tem "tempos e tempos” para estudar música) os coloca como espelhos invertidos para o grupo de internos: os boyzinhos são seu inverso estrutural. Categoria ampla, o ser boyzinho define e abriga várias parcelas da população das quais os jovens internos se julgam excluídos ${ }^{107}$. A esse outro o interno dirige sua revolta ${ }^{108}$.

O clima de revolta foi se diluindo com a aproximação da apresentação. A imagem de refeitório de prisão aos poucos era efetivamente sobreposta pela da coxia. Compunham o cenário o burburinho ansioso, a distribuição dos uniformes e de perfume, as últimas palavras do maestro. Como sempre fazia em suas aulas e ensaios, Márcio ressaltou a importância do momento, a chance que estavam tendo de "mostrar que são gente", "que têm talento", e o fato de estarem lá por “merecimento", porque "são bons no que estão fazendo".

Na platéia, o público da abertura do Festival foi saudado pelo apresentador do evento, que introduziu também o vídeo institucional exibido em um telão. 
Entre as atrações do festival, o vídeo destacava o trabalho do Projeto Guri, que devolvia "a auto-estima e a cidadania" a jovens como os internos da Febem. Na platéia, sentados no chão juntamente com monitores, estavam alguns dos jovens retratados no vídeo.

A apresentação do Hino Nacional e de "Andança” abriu o Festival. Os meninos mantiveram no palco a postura aprendida com o maestro. Foram aplaudidos e assistiram, do palco, a apresentação da orquestra do Mazzaropi. Em pé, em silêncio, atentos. No fim da apresentação, todos os jovens da Febem (do palco e da platéia) deixaram em fila o teatro. Cruzaram, nos corredores, com a atração principal da noite - a Orquestra Sinfônica do Estado de São Paulo - que não chegariam a ouvir. Estavam contentes e cansados. Voltaram aos ônibus, nos quais a maioria dormiu. Não chegaram a ver a cidade, nem o belo jardim que cerca o auditório do teatro.

Sentei sozinha. Um monitor sentou-se ao meu lado, puxou conversa. Depois de me perguntar o que eu fazia, começou a falar da instituição na qual trabalhava havia três anos. "A Febem não recupera ninguém”, começou. Cursos profissionalizantes? "O que adianta ensinar mecânica com carros que nem existem mais? Culinária? Onde eles vão trabalhar depois? Deviam ensinar serviço de pedreiro, marcenaria, e quando o menino saísse daqui, dava para ele um kit para ele poder começar a trabalhar”. Sobre o Guri, disparou com malícia: “O projeto Guri é legal, mas é ilusão. Os garotos gostam principalmente das professoras...”. Procurei lembrar, na hora, se havia professoras no Guri. Não havia, ao menos naquele momento.

O discurso seguia ambíguo até aos poucos revelar meu companheiro de banco: com a fala mansa, palavras bem escolhidas, me contou sobre uma proposta que estava sendo implantada em uma das unidades: a "uTR”. A sigla, que eu ouvira, em conversas dos jovens, associada a maus tratos e castigos em unidades, significava, segundo meu interlocutor, Unidade de Tratamento e Recuperação. Destinada aos líderes que causavam problemas nas outras unidades, estava sendo desenvolvida na uE-12. Ouvi, sob pasmo, uma voz orgulhosa contar como os jovens rebeldes eram alojados em quartos individuais, dos quais saíam "só para 
fazer educação física”, impedidos até de conversar. "A idéia é que fiquem um período curto, voltem para a unidade e, se causarem problema de novo, voltem para um período maior”, explicava. "Estão dizendo que rola couro na ue 12", comentou, sem concordar ou negar. Não consegui prosseguir. Uma gripe, o cansaço da viagem, o peso concreto da barriga no sexto mês da gravidez, sono: tudo foi desculpa para encerrar a conversa. No fundo, era apenas o horror. Apaguei.

A "saída” para Campos do Jordão reforçava a impressão de ambigüidade que me causava a prática musical na Febem. O aparato policial, a restrição à movimentação do grupo, o acompanhamento dos monitores não permitia que fossem esquecidas a estrutura institucional e a condição do interno em quase nenhum momento. A sensação que me acompanhou quando saí da Febem, de madrugada, na volta da viagem, foi a da opressão institucional. A lembrança da prática musical - e suas implicações - ficava tão distante quanto a cidade que deixáramos, tão curta, como os minutos que duram um hino e uma canção num dia inteiro passado entre o ônibus e a sala de espera feia e esfumaçada.

Mas os jovens estavam contentes. As saídas eram esperadas ansiosamente. O sentido só podia ser encontrado uma vez inserido o evento no contexto do cotidiano dos internos. A lembrança dos minutos no palco devem ser contrapostas às horas vazias do pátio, espaço do tempo que não passa. No palco, colocam-se em prática os mecanismos sensíveis específicos à prática musical, como concentração, tensão, alívio, catarse. Educação também sentimental. A apresentação é locus de exposição, construção de personagens, jogo, jogo de espelhos. A performance para o público é fundamental para a visibilidade do projeto, mas também dos jovens que dele participam. Por alguns momentos, a prática musical subverte a condição da internação: durante as apresentações, os "menores" são vistos, sua condição é lembrada pela sociedade mais ampla; durante alguns minutos, perdem a invisibilidade que os caracteriza na situação de reclusão e se tornam o centro das atenções - provocam a reflexão. 


\section{TEMPO DE VIDA, TEMPO MUSICAL \\ [MÚSICA E TEMPORALIDADE]}

Olhe, essas pecinhas insignificantes duram sete minutos, em média, não é? E esses sete minutos têm alguma coisa em particular, têm princípio e têm fim, destacam-se e são, de certo modo, preservados da ameaça de se perderem sem mais nem menos na monotonia geral. Além disso, são ainda muitas vezes subdivididos pelas partes da peça, e estas, por sua vez, se compõem de compassos, de maneira que sempre acontece alguma coisa e cada instante recebe um certo sentido, ao qual se pode agarrar, ao passo que normalmente...

Não sei se me expressei...

Joachim, personagem d' A montanha mágica, de Thomas Mann

Ambas [a música e a mitologia] são, na verdade, máquinas de suprimir o tempo. Abaixo dos sons e dos ritmos, a música opera sobre um terreno bruto, que é o tempo fisiológico do ouvinte. [...] ao ouvirmos música, e enquanto a escutamos, atingimos uma espécie de imortalidade. Claude Lévi-Strauss, em $O$ cru e o cozido

[a música] ajuda a matar o tempo Jovem interno na Febem

A música tem com o tempo relação bastante peculiar. Duração é uma de suas quatro propriedades fundamentais ${ }^{109}$. Na escrita musical ocidental, há figuras para indicar a duração de um som ou de sua ausência (pausa) em uma composição. Números são usados para descrever como é pensada a divisão da música 
em "unidades de tempo". Em uma valsa, por exemplo, a música é dividida em compassos de três unidades de tempo, sendo a primeira, convencionalmente, a que é tocada com mais intensidade - тuм, tam, tam...

A música põe em suspensão o tempo cotidiano, ao dotar de conteúdo sonoro, sentido e ordem (o "princípio e fim” de Joachim) um determinado espaço de tempo.

\footnotetext{
"Quando a música é escrita com gênio, todos os acontecimentos são cuidadosamente selecionados, a fim de construírem a subestrutura para relações excepcionalmente profundas. [...] Assim, embora por um breve espaço de tempo, alcançamos uma compreensão mais profunda do mundo (ou, pelo menos, de uma pequena parte dele)... [...] É por esse motivo que a música pode ser transcendente. Durante alguns momentos, ela nos torna maiores do que realmente somos, e ao mundo, mais ordenado do que ele realmente é.” (Jourdain, 1998: 416, itálico meu)
}

O tempo da escuta musical difere do tempo da leitura ou da observação de uma obra de arte. Edward Said tece uma comparação: "na literatura e na pintura o tempo não está sempre avançando: você pode parar, voltar atrás, ler, reler. [...] não se trata de uma situação tão imperiosa como a do concerto, que [...] dita a lógica de ir do começo ao fim” (Barenboim e Said, 2003: 45). O pianista e maestro Daniel Barenboim, interlocutor de Said nesse diálogo sobre música e sociedade, destaca no universo da música de concerto sua característica única de “irrepetibilidade”. A música "em concerto" é única. Pode ser gravada e reproduzida, mas a gravação não possibilita as emoções ímpares sentidas pelo público que acompanha o espetáculo. Para Barenboim, nada na vida se compara à "empolgação de conseguir realmente viver uma determinada peça do começo ao fim sem interrupção, sem sair dela” (idem: 51).

Lévi-Strauss (s/data: 240/4), ao analisar a estrutura dos mitos, percebe que estes operam em um sistema de referência temporal de duas dimensões: esse sistema é ao mesmo tempo diacrônico e sincrônico, reunindo as propriedades 
da "língua” e da "fala”. A partir de Saussure, Lévi-Strauss argumenta que a língua pertence ao domínio do tempo reversível, e a fala, ao domínio do tempo irreversível. O mito combinaria as propriedades desses dois domínios: por um lado, diria respeito sempre a acontecimentos passados ("antes da criação do mundo"), por outro, esses acontecimentos formariam uma "estrutura permanente", que se relaciona com passado, presente e futuro. Lévi-Strauss percebe na análise de uma partitura musical um modelo para a análise mítica, uma vez que a partitura pode ser lida na horizontal e na vertical, ou seja, em diacronia ou sincronia, em melodia ou harmonia. A música compartilha, portanto, com o mito sua característica temporal de simultânea sincronia e diacronia: na partitura, a música revela-se em sua estrutura, é reversível; em "concerto”, como notou Barenboim, faz-se irreversível, e única, portanto ${ }^{110}$.

$\mathrm{Na}$ obra em que mais se aproxima do universo musical, $\mathrm{O}$ cru e o cozido, Lévi-Strauss aprofunda a comparação entre mito e música. Afirma que ambos transcendem o plano da linguagem articulada, apesar de necessitarem, como aquela, de uma dimensão temporal para se manifestarem. "Mas essa relação com o tempo é de natureza muito particular: tudo se passa como se a música e a mitologia só precisassem do tempo para infligir-lhe um desmentido". Daí a definição do mito e da música como "máquinas de suprimir o tempo", que nos colocam, como ouvintes, numa condição temporária de imortalidade (LéviStrauss, 1991: 24).

A música, enfim, domestica o tempo e os sons, implica síntese e ordem. Claude Debussy teria comentado, certa vez, que havia mais a ganhar observando o sol nascer do que ouvindo a Sinfonia Pastoral de Beethoven. "Felizmente, sua convicção não o impediu de compor”, argumenta Pierre Jourdain. Os amanheceres são habitualmente suaves e os seres humanos, em geral, pouco reagem a amanheceres, mesmo quando são extraordinários. "Em contraste, a música, e a arte em geral, proporcionam à mente experiência cuidadosamente ordenada - um amanhecer perfeito para sempre". "Um bando de pássaros piando forte produz todas as notas isoladas de uma sinfonia, mas não numa hierarquia ordenada de agrupamentos" (Jourdain, 1998: 414-15). O nascer do sol e a Pastoral remetem, 
em síntese, à Natureza e Cultura, e à passagem explicitada por Lévi-Strauss: "a natureza produz ruídos, e não sons musicais, que são monopólio da cultura enquanto criadora dos instrumentos e do canto" (1991: 30).

Principal exemplo do molde cultural da música é a existência das escalas, “paradigmas construídos artificialmente pelas culturas” (Wisnik, 1999: 71). Representam a "grande diversidade das culturas musicais: que som interditar ou escolher!”, nas palavras de Miranda (2001: 23). A possibilidade de extrair, eleger e ordenar ou silenciar certos sons, "a partir do estoque polimorfo dos ruídos da natureza” (idem) é sem dúvida a base da diversidade cultural no que diz respeito à música.

Entretanto, insiste Lévi-Strauss, a música é Cultura e Natureza. Opera, além do molde cultural (as escalas), no molde natural ao dirigir-se ao tempo psicológico, fisiológico e "até visceral" do ouvinte: a "periodicidade das ondas cerebrais e dos ritmos orgânicos, capacidade da memória e capacidade de atenção" (Lévi-Strauss, 1991: 25). É a partir desta dupla ancoragem - Natureza e Cultura - e da dupla dimensão temporal presente no mito e na música que Lévi-Strauss derivará seu potencial extraordinário de agir sobre "o espírito e os sentidos", de mover "idéias e emoções" (idem: 35).

A conexão entre música, tempo e corpo pode ser observada ao analisarmos uma categoria fundamental à leitura da música ocidental tonal: o "andamento". É por meio de indicações como "allegro", "andante", "lento” etc. na partitura que o músico saberá com que velocidade e intenção deve ser tocada determinada composição. Wisnik lembra que as categorias de andamento são fundamentadas em disposições físicas e psicológicas. O fato da terminologia tradicional indicar como "andante" a medida média de ritmo de uma música é sintomático da aproximação entre tempo musical e tempo corporal, entre pulsação rítmica e pulso/ coração. "Os indianos usam o batimento do coração ou o piscar do olho como referência”, um teórico do século xviı sugeria que "o padrão regular de todos os andamentos, seria 'o pulso de uma pessoa de bom humor, fogosa e leve, à tarde' (!)” (Wisnik, 1999: 19). A aproximação entre corpo, tempo e música pode ser ainda mais radical: "O feto cresce no útero ao som do coração da mãe", "o ritmo 
está na base de todas as percepções". Daí, pode-se intuir o "grande poder de atuação [da música] sobre o corpo e a mente, sobre a consciência e o inconsciente, numa espécie de eficácia simbólica” (idem: 30).

"Eu gosto mesmo é de concerto pesado, que faz esquentar o sangue."

A frase de um jovem interno na Febem ecoa a reflexão sobre relação entre música e fisiologia. Quando questionei o rapaz, estudante de violino havia dois anos, sobre o que era "concerto pesado" (sobretudo por conhecer o repertório das orquestras do Projeto Guri e não identificar neste nada "pesado"), ele me respondeu: "qualquer coisa que toque rápido e faça esquentar o sangue". Os exemplos que ele deu de tal repertório - "Brincando na Neve", "Minueto" - estavam distantes do que eu entendia como "pesado", um show de heavy metal, por exemplo, ou, no mínimo, um concerto grosso ${ }^{111}$. Mas, no contexto da internação, usar o corpo para fazer música, subir a um palco e ser aplaudido pode, efetivamente, esquentar o sangue...

É essa relação entre o tempo da prática musical e as temporalidades vividas pelos jovens que pesquisei que pretendo desenvolver neste capítulo.

\section{O tempo perigoso}

cabeça parada, oficina do diabo

O dito popular - comum nas prisões (para adultos ou jovens) - poderia ser o slogan dos projetos voltados para a infância e juventude - infratora, carente ou não - no país. O fato é que pais, alunos, proponentes, professores e a sociedade brasileira de forma mais ampla (incluídos os formadores de opinião) afirmam a necessidade da ocupação do "tempo ocioso" das crianças e jovens. O mesmo vale para os jovens internados: a ocupação do tempo é a idéia que fundamenta a política institucional da Febem em São Paulo, ao menos desde as grandes rebeliões de 1999.

Tais pensamentos têm como princípio a noção de que o tempo "ocioso" é 
um tempo perigoso. É preciso, afirma-se, ocupar o tempo. Fato curioso é que tal necessidade seja colocada em contextos muito diversos: na Febem, na periferia de São Paulo ou de outras capitais, nos centros urbanos em geral, inclusive entre famílias de classe média ou alta. O "perigo” do tempo livre une crianças e jovens separados pela desigualdade social e cultural ímpar em nosso país.

Uso o termo "tempo livre" aqui no sentido de tempo liberado da escola, tal como surge na fala dos sujeitos pesquisados. Na literatura sobre lazer, a noção de tempo livre é geralmente construída em oposição ao universo do trabalho. Alguns autores, no entanto, advertem que o tempo resultante da diminuição na jornada de trabalho ${ }^{112}$ é "tempo liberado", não "tempo livre”. Excetuadas as horas gastas com transporte, cuidados obrigatórios com a casa e a família, restaria o "tempo livre", que, na acepção de Erich Fromm, é ainda diferenciado quando é um "tempo livre de"(obrigações) ou um "tempo livre para" (a liberdade) (apud Waichman, 2001: 35).

É interessante notar que, na história do pensamento ocidental, entre os gregos, o ócio já tenha sido visto como ideal de vida:

“No grego sckolé (ócio) opõe-se a asckolé, que tem a conotação de servidão. Curiosamente, do termo sckolé deriva a palavra escola. Sckolé era o desenvolvimento dos valores supremos da cultura grega, que permitiam a contemplação da sabedoria. [...] Tinham tempo para isso aqueles que, com o trabalho dos escravos, possuíam a riqueza material possibilitadora de um tempo para o ócio. E esse tempo livre era, justamente, o oposto do tempo para não fazer nada. Era o tempo do saber não utilitário. [...] O ócio é um ideal de vida, portanto, um fim; ao passo que o trabalho, que o possibilita, é um meio.”

(Waichman, idem: 44)

É dos romanos a concepção do ócio como um tempo de não-trabalho, um complemento ao trabalho, que "permite recuperar-se para ele” (idem: 45). Já a atribuição de valores negativos ao ócio tem origem a partir da Revolução Industrial, quando o ócio e o tempo livre são incompatíveis com a geração de riquezas e 
característico de "classes parasitárias contrárias ao progresso social” (idem, ibidem). Têm origem aí as noções de que "tempo é dinheiro” e que “o ócio é a mãe de todos os vícios".

O século xx permite o desenvolvimento da concepção do ócio como "prêmio", "conquista do esforço de trabalho realizado" (Loewenstein, apud Waichman, 2001: 52), e conseqüentemente, "tempo disponível para o consumo" (Mead, apud. idem, ibidem). Nos estudos sobre o lazer desenvolvidos ao longo deste século, discutem-se as naturezas subjetivas ou objetivas do ócio. Para Munné (apud idem: 86), o ócio é dotado de subjetividade, uma vez que implica o uso do tempo pelo indivíduo para desenvolver as suas necessidades (fazer "o que queremos”). Para Dumazedier (apud idem: 87), o ócio é concebido com base na análise objetiva das atividades realizadas: é, portanto, um conjunto de ocupações consentidas com função de descanso, diversão e desenvolvimento.

Pablo Waichman, nesse levantamento de análises sobre o lazer, aponta como tendência na teoria sobre o lazer do fim do século xx a discussão da transformação do ócio em efetivo "tempo livre", no sentido de "tempo em que o indivíduo desenvolve suas necessidades, quando se autocondiciona" (idem: 85). Em sua acepção, o "tempo livre" corresponderia à "liberdade plena", que vai além da "liberdade de" e alcança a "liberdade para":

\footnotetext{
"O tempo livre será tal quando significar a liberdade no tempo e não do tempo.” (idem: 96)
}

Victor Turner desenvolve reflexão neste sentido. Dentre inúmeras analogias entre sociedades de pequena e grande escala ${ }^{113}$, Turner pensou a relação entre situações liminares de sociedades do primeiro tipo e os fenômenos relacionados ao lazer nas sociedades complexas, aos quais o autor chamou de liminóides. Em From ritual to theatre (1982), Turner procura mostrar que os gêneros de lazer industrial - como teatro, poesia, balé, romance, filme, esporte, rock, música clássica, arte etc. - são, de certa forma, correspondentes aos processos liminares que implicam o uso de máscaras, o disfarce, a inversão e a paródia da realidade 
profana em mitos e estórias. A principal semelhança entre os processos em questão é que ambos são reflexivos, estimulam os que neles estão envolvidos a pensar a sociedade.

Turner (idem: 36-7) ressalta o caráter libertário dos gêneros de lazer. Para o autor, o lazer é um fenômeno "tipicamente urbano", que pressupõe o trabalho. Durante o tempo do lazer, fica-se livre de uma série de obrigações institucionais e dos ritmos cronologicamente regulados da fábrica e do escritório; tem-se uma chance de recuperar e curtir os ritmos biológicos e naturais. Lazer é também liberdade de entrar em (e gerar) novos mundos simbólicos de entretenimento, esportes, jogos e diversões de todos os tipos. Liberdade de transcender as limitações sociais estruturais, liberdade de jogar com idéias, fantasias, palavras, pintura, relações sociais. Para Turner, o lazer é potencialmente capaz de liberar poderes criativos, individuais ou comuns, para criticar os valores dominantes da estrutura social. A prática musical está entre as atividades consideradas por Turner como liminóides.

Entre as concepções de tempo perigoso e tempo para a liberdade há um trajeto a ser percorrido. Na fala dos sujeitos pesquisados - jovens, pais, coordenadores de projetos de intervenção social - o ócio é referido como algo perigoso e indesejado. Ocioso é todo o tempo que sobra antes ou após o período escolar (por se tratar de crianças e jovens, é a escola e não o trabalho a principal contrapartida ao ócio). É senso comum a idéia da necessidade de ocupação deste tempo. Há algumas possibilidades para tal: ficar em casa vendo Tv ou sem fazer nada, ficar na rua, participar de alguma atividade, para alguns, trabalhar.

A rua não é opção para a maioria das crianças e jovens que conheci. O "fazer nada" é desvalorizado pelos jovens e crianças que já participam de alguma atividade/oficina. As atividades planejadas - quase sempre relacionadas ao esporte ou à educação artística - são vistas como as principais formas de ocupação do tempo, além da religião, quando é o caso. Cabe investigar o porquê do medo do ócio, os sentidos da ocupação do tempo com música e as possibilidades do tempo musical como um tempo para a liberdade. 


\section{a casa e a rua [revisitadas]}

“Os que não estão aqui dentro, quando não estão na atividade, estão na rua. Então você está tirando da rua através da música.”

Ana Laís Parro dos Santos, coordenadora do Pólo pof Morumbi do Projeto Guri

"A gente é dona-de-casa, não é fácil ficar três dias fora. Mas tem que tirar da rua. Na rua, se aprende cada coisa...”

Mãe de aluna do pólo Mazzaropi do Guri

"Eu tenho quatro meninos (de 17, oito, cinco anos e um de 11 meses) e uma menina. Ela tem vontade de fazer as coisas. Os meninos não fazem curso. Ficam em casa. Na rua não vai, só na porta de casa com os colegas dele. A menina, antes daqui, só ficava em casa. Porque na rua eu não deixo brincar, não deixo sair, nada.”

Marina, mãe de aluna do pólo Mazzaropi

“A duração se exprime sempre em extensão. Os termos que designam o tempo são tomados à linguagem do espaço. Quando invocamos o tempo, é o espaço que responde ao chamado”. A análise de Bergson (1974: 223; apud Silva, 2000) quanto à relação entre tempo e espaço é observada nas diversas falas dos atores pesquisados: o tempo "ocioso" é relacionado à rua e a seu "perigo". "Ocupar o tempo" é sinônimo de "tirar as crianças da rua”.

Roberto DaMatta enfatizou a passagem "dramática” entre casa e rua, sendo esta última o espaço do perigo, das relações impessoais e desumanas. A rua é local de "indesejável individualização, de luta e de malandragem"(DaMatta, 1991: 61). A situação atual das metrópoles brasileiras tinge com cores ainda mais dramáticas esta caracterização da rua: é o domínio do crime organizado, é palco de uma violência cada vez mais efetiva, que atinge adolescentes cada vez mais novos.

No capítulo 2, mostrei como a ocupação do tempo fora da escola é um 
dos principais objetivos dos projetos governamentais ou não-governamentais destinados aos "jovens em situação de risco". Isto porque o ócio associado à rua é considerado um dos principais fatores de tal "risco".

Os pais de alunos não medem esforços em sua maratona para manter os filhos ocupados. Mesmo alguns jovens associam o espaço da rua a aspectos negativos, como o crime e a violência, embora, para eles, a casa não seja tampouco lugar valorizado. Para várias das crianças e jovens entrevistados, ficar em casa é sinônimo de ter que ajudar a mãe a lavar roupa, lavar louça, fazer comida.

Daiane: Antes de eu vir estudar pra cá eu não fazia nada, e era ruim ficar em casa sem fazer nada. Aí minha mãe falou assim: vou colocar vocês num curso $[\ldots]$.

P: Como é seu dia a dia?

R: Chego da escola, vou almoçar, venho para cá segunda e às quatro horas vou embora. Terça-feira, eu não faço nada. Fico em casa assistindo televisão, depois vou arrumar a cozinha...

P:Ajuda sua mãe...

R: Ajudo... Quarta, faço a mesma coisa: chego da escola, almoço, troco roupa e venho para o Mazzaropi. Quinta-feira, eu almoço, descanso um pouco, vou para a igreja, e [de volta] da igreja descanso um pouco, assisto televisão. Sexta-feira, eu chego da escola, almoço, brinco e vou para a igreja à noite de novo, chego e vou dormir.

P: Final de semana...

R: Sábado, eu acordo cedo, sete, oito horas da manhã. Eu lavo a louça, limpo a cozinha toda, aí eu faço leite, dou para meus irmãos, para minha mãe, para meu pai. Aí vou assistir televisão, depois da televisão, vou almoçar. Depois, mais televisão. Aí, à tarde, arrumo a cozinha, mais televisão, depois tomo café da tarde, lavo a louça, aí mais televisão... Eu assisto bastante televisão. A noite, eu assisto televisão. No domingo, eu vou para a escola dominical de manhã na igreja, volto, lavo a louça e assisto televisão, a tarde, assisto tv até às cinco, e depois eu vou para a igreja. [...] Depois eu chego e vou assistir 
televisão. Depois eu durmo, vou para escola, aí começa tudo de novo.

P: Se você não estivesse fazendo Guri, o que você ia fazer?

$R$ : Nada, praticamente nada. Nadica.

Daiane dos Santos Augusto, 11, há três anos estuda violino no pólo Mazzaro-

pi do Projeto Guri

Além das tarefas domésticas e da "lição de casa", o tempo restante é geralmente ocupado com a televisão. Várias crianças e jovens não podem sair de casa (ou do prédio) para brincar. Para estes, a rua não é uma opção (os pais não deixam, eles não querem ir para a rua). Alguns alunos, quando questionados se a música era melhor que a escola, responderam que ambos são melhores que ficar em casa.

É interessante notar, com DaMatta, que casa e rua não são espaços de significação estanque. Uma característica importante do Projeto Guri é levar as crianças e jovens participantes a vários espaços da cidade, permitindo uma efetiva ampliação de horizontes. É um processo de saída da casa, de ocupação dos espaços públicos. Por outro lado, nas falas dos jovens é destacado o fato de "sentir-se em casa" nesses espaços (nos pólos onde ensaiam, nos anfiteatros em que se apresentam). Relações de solidariedade e confiança são responsáveis pela familiarização com espaços públicos antes marcados pela impessoalidade.

José Guilerme C. Magnani construiu a categoria pedaço para descrever a relação com o espaço urbano, intermediária entre o mundo da casa e o da rua. O pedaço é um espaço onde são construídas "lealdades, códigos compartilhados, pertencimentos". O pedaço implica uma rede de relações "que combina laços de parentesco, vizinhança, procedência, vínculos definidos por participação em atividades comunitárias e desportivas etc.” (1992: 192/3).

A participação em um projeto como o Guri corresponde, efetivamente, à inserção da criança ou jovem em um pedaço, no qual antigos vizinhos e novos amigos passam a constituir uma "família”, como pensada por Alessandra. O tempo despendido nas atividades do projeto é um dos fatores que contribuem para que, além do aprendizado musical, sejam construídos vínculos pessoais e grupais que conferem a um espaço público qualidades próximas do universo da casa. 
Tipicamente, o participante do Guri vai ao pólo duas vezes por semana, no mínimo. Nestes dias, passa toda a tarde em atividades como aula em grupo, ensaio de orquestra, coral ou camerata, prática do instrumento. Nos intervalos entre as atividades, encontram-se nos corredores para conversar, às vezes para comer. Muitos vão ou voltam juntos para casa. São vizinhos, que chegaram ao Guri por indicação de outros vizinhos. Os mais velhos estendem a convivência para espaços exteriores ao da prática musical. Saem juntos nos fins de semana, vão a museus, shows. Alguns freqüentam ou passam a freqüentar a mesma igreja. Alessandra, informante privilegiada, me contou também que mesmo aqueles que saem do Projeto continuam em contato: combinam algum encontro, avisam uns aos outros quando vai haver algum concurso, uma oportunidade de emprego. São vínculos que perduram.

Perguntei para os garotos se eles faziam o coral. Eles responderam negativa-

mente. Os rappers completaram: "eles fazem música de rua".

Trecho do caderno de campo, referente à pesquisa na Febem

Um parêntese se faz necessário nessa reflexão sobre a rua e o tempo. Diferentemente do tempo ocioso - nunca desejado - a rua é valorizada em algumas formas de sociabilidade juvenil na periferia. Em ao menos um contexto - o da internação - a rua é, obviamente, sinônimo de liberdade e, em alguns casos, de uma cultura própria, o rap. Esse estilo musical, caracterizado por canções de denúncia social mais faladas que cantadas - e parte de um movimento mais amplo, o Hip Hop -, vem ganhando, desde a década de 80, um público bastante relevante, sobretudo na periferia paulista.

Pedro Guasco, em sua dissertação sobre o rap paulista, afirma que no discurso dos rappers "a rua aparece como espaço de cultura e metáfora da sociedade" (Guasco, 2001: 118). Para os rappers, a rua é um "lugar da experiência diante do social", "um tipo de conhecimento" (idem: 120). Marilia Sposito, apesar de notar as "alterações no padrão das relações sociais que ocorrem nas ruas e bairros da cidade" em virtude do crescimento do crime, do tráfico de drogas 
e da corrupção policial, percebe a rua, na cultura dos rappers, como espaço de sociabilidade que se sobrepõe aos locais socializadores por excelência, como a escola (Sposito, 1994: 167).

No trecho do caderno de campo que reproduzi acima, está registrado um dos poucos momentos da pesquisa em que o tema da cultura de rua surgiu na fala dos sujeitos pesquisados - e, mais importante, como contraposição à produção musical realizada no Projeto: “eles não são do coral, fazem música de rua”. No entanto, cabe notar que a fala não é de internos e participantes do projeto, mas de rappers profissionais que realizavam, naquele momento, um projeto chamado Realidade em parceria com o setor de Projetos Especiais da Febem. O projeto consistia na seleção de jovens que cantassem ou compusessem raps para participar da gravação de uma das faixas do CD do grupo Jigaboo. Os integrantes do grupo iam à Febem ouvir os raps compostos pelos jovens e selecionar os participantes do $\mathrm{CD}^{114}$.

Para os participantes do Guri, tal separação entre música de rua e a música como aprendida no Projeto, não parecia tão evidente. Tanto que membros do coral, ensaiados pelo regente do Guri, participaram da gravação do cD, cantando o refrão da música em um arranjo para três vozes. Ao menos no plano musical, soluções foram encontradas de aproximação entre universos sonoros e sociais diferentes, resultando em um rap com interferências da técnica vocal e de composição eruditas.

O fato é que o universo do rap - e sua valorização da rua como espaço de cultura - não é o único referencial dos jovens da periferia paulista. Dentre os jovens que pesquisei, o rap tinha mais público no pólo Febem do Projeto Guri. Nos demais pólos - Mazzaropi, Pof e São Remo ${ }^{115}$ - as preferências musicais dividiam-se entre o samba, o pagode, o rock, o pop internacional.

Importa notar que, diferentemente dos rappers profissionais que faziam questão de contrapor sua música "de rua" à música feita no Guri, os participantes do projeto não consideram que aprender música "na escola" interfira com o resultado final de sua atuação como músico nas ruas. Conheci jovens pagodeiros, já atuantes profissionalmente em suas comunidades, que faziam canto no Guri 
para aperfeiçoar sua técnica vocal. Outros, também pagodeiros, estudavam percussão e tocavam nas orquestras do projeto, onde achavam estar aprendendo novos ritmos (frevo, maracatu, samba) com os quais poderiam incrementar suas apresentações nos bares da comunidade. Jovens estudantes de violão, que aprendiam a dedilhar melodias clássicas nas aulas do Guri, diziam que depois das aulas havia ficado mais fácil tocar seus rocks preferidos, inclusive os trechos solos que tocavam "de ouvido".

Fechando o parêntese: registrei, em poucas linhas, a existência, no meu universo de pesquisa, de um campo no qual a rua não é associada apenas ao perigo, mas sim à possibilidade de produção cultural. Mais ou menos distantes do universo do Rap, os jovens que conheci no Guri, ao fugir dos perigos do tempo ocioso e da rua, encontraram em um espaço fora de suas casas novas possibilidades de sociabilidade e novos acessos para as ruas e alguns de seus espaços. Em vez de se fecharem em suas casas, esses jovens percorrem trajetos mais ou menos longos, de ônibus, carro ou a pé, para ir ao pólo, duas vezes por semana, ou mais, conforme o calendário de apresentações. O que procuro mostrar neste e nos demais capítulos é que apesar de pontos de partida díspares - o "medo" da rua x a "cultura de rua" -, as práticas musicais no Guri ou nos "pedaços" 116 dos rappers implicam a apropriação do espaço urbano, a ampliação de horizontes, o contato com a diferença. Os produtos culturais que resultam das práticas em questão revelam uma diversidade que é constitutiva da própria experiência de juventude nas periferias paulistas.

\section{Intervalo}

“Comecei o Guri para matar o tempo". Dessa maneira, a maioria dos alunos descreve sua entrada no projeto. Mais de uma vez ouvi de coordenadoras que um dos principais objetivos do Guri é "tirar as crianças da rua”. Se por um lado é evidente a qualidade ocupacional desse ou de outros projetos de arte-educação, esportes etc. - uma vez que efetivamente ocupam parte do tempo "ocioso" das 
crianças e jovens - é preciso perguntar pela especificidade dessa ocupação de tempo. No caso aqui estudado, é o tempo da prática musical que deve ser objeto da reflexão.

\begin{abstract}
"Mesmo antes de tocar violino, eu sempre estava com um walkman, música na cabeça. Música é tudo. Quando você está triste, você pára e escuta uma música para ver se melhora o ânimo. Quando tá meio chateada, escuta música. É fundamental pra todo mundo. Não tem aquele velho ditado que diz ‘quem canta seus males espanta’? Eu levo bem a sério.”

Tatiane Miê Hirano, 18, estuda violino no Mazzaropi há três anos
\end{abstract}

Tatiane lembra que se "pára” para escutar uma música. Música implica uma interrupção no fluxo da vida cotidiana. A pausa faz mudar o humor. A música altera ritmos, sensibilidades, sintonias. Proponho pensar a prática musical como intervalo, espaço de liminaridade e, eventualmente, de reflexividade. É dessa maneira que Johan Huizinga, em seu tratado sobre o jogo, caracteriza as atividades lúdicas, dentre as quais inclui a música ${ }^{117}$ : o jogo não é vida ordinária, é “intermezzo", descanso. "É pelo menos assim que, em primeira instância, ele [o jogo] se nos apresenta: como um intervalo em nossa vida cotidiana” (Huizinga, 2000: 12). Aí também a afinidade entre jogo e música: ambos situam-se "fora da sensatez da vida prática, nada tem a ver com a necessidade ou a utilidade, com o dever ou com a verdade" (idem: 177).

A matriz da leitura de Huizinga é aristotélica. O autor retomará o filósofo grego e sua reflexão sobre a música. Apesar de ressaltar que música, para os gregos, abarca mais do que o que nós entendemos hoje como tal, incluindo também a dança, as artes e demais habilidades presididas por Apolo e pelas Musas, Huizinga destaca os fundamentos da definição de Aristóteles sobre a natureza da música e os utiliza na reflexão acerca das esferas lúdicas em nossa sociedade.

Para Aristóteles, a música, como o sono e a bebida, não é em si mesma coisa importante ou séria, mas agradável e capaz de "afastar as preocupações" (apud Huizinga, idem: 180). Por outro lado, pode conduzir à virtude, na me- 
dida em que, "tal como a ginástica, é capaz de exercitar o corpo, alimenta uma certa ética e nos permite gozar as coisas de maneira adequada” (idem, ibidem). E ainda, a música pode contribuir "para a recreação mental e para a aquisição de conhecimentos". Desta última das "funções" da música descritas por Aristóteles, Huizinga destaca a interpretação do termo "recreação mental", que poderia ser traduzido também como o "passar" ou o "gastar" do tempo. "Traduzi-la por "passatempo' só é aceitável quando se tem perante o trabalho e o ócio a mesma atitude de Aristóteles", ou seja, o ócio como princípio do universo, coisa preferível ao trabalho, e, sem dúvida, o fim de todo trabalho.

Assim, na leitura aristotélica, a música é ora instrumento de relaxamento e torpor (como o vinho), ora meio de exercício do corpo e da virtude do ouvinte. É, entretanto, sempre passatempo, bem entendida a importância, para os gregos, desse tempo a ser "gasto", o ócio.

Huizinga, com Aristóteles, percebe o trânsito das atividades lúdicas (como a música ou o jogo) entre o intervalo - o extraordinário - e a onipresença: “Todavia, em sua qualidade de distensão regularmente verificada, ele [o jogo] se torna um acompanhamento, um complemento e, em última análise, uma parte integrante da vida em geral" (Huizinga, idem: 12). Na fala dos jovens que pesquiso, tal trânsito se percebe no modo como descrevem os significados do fazer musical: ora é um "mata tempo", ora representa “tudo" em suas vidas ${ }^{118}$. Era comum ouvir dos alunos que tinham começado a tocar para "matar o tempo" - tanto na Febem como em outros pólos -, porque antes não faziam nada. Com o tempo, contavam, passaram a gostar do aprendizado e, por fim, não conseguiam mais imaginar a vida sem a prática musical.

Importante fator que possibilita esse trânsito é a qualidade do jogo - e da música - de induzir à imersão. O jogo é dotado de intensidade, de fascínio, de uma "capacidade de excitar" - sua característica primordial, de acordo com Huizinga (idem: 5). É ainda "atividade livre, conscientemente tomada como 'não-séria' e exterior à vida habitual, mas ao mesmo tempo capaz de absorver o jogador de maneira intensa e total" (idem: 16).

Em geral, a experiência de imersão não é solitária. Como lembra DaMatta, 
na era do individualismo, o momento extraordinário nos transforma em seres coletivos: "somos dupla ou somos torcida, partido, público, multidão" (DaMatta, 1991: 45). Os exemplos são, quase todos, retirados da esfera do lúdico: jogo (dupla, torcida, multidão), música / espetáculo (público, multidão). Tal caráter coletivo vivenciado na atividade lúdica é destacado por Huizinga (idem, ibidem): "a sensação de ter tratamento exclusivo, estar dedicado em conjunto a algo importante, de diferenciar-se em comum de outros [...] exerce um efeito mágico que ultrapassa a duração do jogo". Interessante notar que Huizinga destaca a possibilidade do efeito "mágico" da experiência coletiva perdurar além do tempo do jogo. No caso da prática musical em conjunto aqui estudada, é essa possibilidade uma de suas características mais importantes no que diz respeito às suas conseqüências não apenas musicais - na vida dos jovens participantes, como pretendi mostrar no capítulo 4, em que discuto os sentidos da performance para os jovens músicos.

A imersão é marcada também por mudanças na concepção de tempo: em competições "segundos valem ouro"; no cinema "momentos produzem emoção" (DaMatta, idem: 42), a passagem de dias, meses ou anos são representados em segundos. O tempo [da execução, de estudo] musical pode ser medido em horas - minutos de estudo, de aula - ou sentido, por exemplo, no corpo que aquece, no corpo que cansa. O tempo da escuta musical é percebido de formas diversas conforme o envolvimento daquele que é atingido pela música. Um concerto pode ser longo, demorado e até interminável quando não se está envolvido. É veloz, intenso, "passa” rápido para aquele que imergiu.

A prática musical proposta no Guri - o aprendizado dos instrumentos de orquestra, sobretudo - demanda alguma disciplina e dedicação de tempo para o estudo. Por não se propor a formar músicos, efetivamente, o projeto não exige a quantidade de horas de estudo que normalmente se exigiria de estudantes com objetivo de se profissionalizar. O maestro que rege a orquestra do Mazzaropi me disse, certa vez, que o ideal seria se todos os alunos estudassem umas três ou quatro horas por dia, mas, não sendo possível tal dedicação, era esperado um estudo de pelo menos uma hora diária.

No Guri, nem todos os alunos possuem o instrumento. Os que não o pos- 
suem, podem ir ao pólo estudar fora do horário de sua aula, mas tal dedicação é complicada: implica gastar mais com condução, ir ao pólo mais um dia na semana etc ${ }^{119}$. Já, dentre os que possuem o instrumento, conheci desde aqueles que diziam estudar por cerca de quatro horas por dia, até aqueles que se esforçavam em estudar pelo menos 15 minutos, conforme orientação do professor. Em alguns casos, o tempo e o espaço de estudo foram negociados lentamente com a própria família (que precisa, muitas vezes, dividir os poucos cômodos da casa com o "barulho" de um instrumento que, no início, é invariavelmente mal tocado). Em outros, a prática do instrumento em casa passou a constituir-se em um espaço-tempo próprio do jovem. Alguns estudantes de violão me contaram que gostavam mesmo era de tocar sozinhos, em seus quartos, durante horas, após a escola.

Em todo caso - e mesmo se considerada somente a aula conjunta de música ou o ensaio - aprender música implica uma dedicação efetiva de tempo e energia. Sendo uma atividade opcional e livre, tal dedicação não ocorreria se não houvesse um envolvimento real dos alunos com o aprendizado. Esse envolvimento é construído de diversas formas. Há a atração pela novidade: conseguir extrair sons de instrumentos pouco conhecidos, como o violino ou o clarinete, já é um desafio estimulante. Há os avanços perceptíveis a cada aula: os sons começam a ficar mais limpos, novas notas são aprendidas a todo o momento, as primeiras melodias são obtidas já após algumas aulas. Há o efeito do conjunto: tocar com outras pessoas, mesmo que a maioria iniciante, produz uma sonoridade cheia, da qual o aluno e seu instrumento passam a fazer parte. A orquestra precisa do músico como este precisa dela para ser ouvido. Há sempre um objetivo a ser alcançado em uma aula ou no estudo privado: ler uma nova música, ensaiar um repertório, aprender um movimento. As inúmeras repetições nunca são em vão. Ao final da atividade (aula, estudo, ensaio), algum resultado foi obtido, e ele é, em geral, perceptível (sobretudo, audível) para o estudante. Há, principalmente, o prazer de se perceber fazendo música, criando o belo - e isso é possível desde o primeiro dia de aula até o fim da vida do músico.

No pólo Mazzaropi, conheci estudantes de 10,12 anos que me disseram ter 
ficado mais organizadas após a entrada no Guri. "A gente aprende a administrar melhor o nosso tempo", dizia uma menina. Para ela, não estava mais em questão o tempo ocioso: o dia estava repleto de atividades que precisavam ser realizadas com algum método. No mesmo pólo, vários jovens me narraram as mudanças em seu cotidiano a partir das aulas no Guri: os dias no pólo ou o estudo em casa implicaram a diminuição das horas na frente da Tv e uma melhor divisão de suas atividades no dia a dia.

Mas o que mais me impressionava nas atividades dos diversos pólos era o tempo que os alunos - jovens e crianças de até sete, oito anos - passavam tocando ou cantando juntos. Aulas e ensaios longos, de até quatro horas, eram comuns em alguns pólos, como no da Febem. Em momentos que precediam apresentações, os alunos passavam boa parte do tempo treinando uma música ou uma seqüência, ensaiando com o maestro o que seria apresentado. Não observei muitas expressões de desânimo ou desinteresse. Mesmo sem a presença do professor ou maestro, os alunos discutiam partes da execução entre si, explicavam uns aos outros sobre seu instrumento, concentravam-se em fazer música.

Schechner, ao refletir a performance, mostra que essa, ao promover a desconstrução e a reconstrução do corpo, marca as experiências de vida dos performers ${ }^{120}$. Por isso, não concorda em pensar a performance ${ }^{121}$ como interrupção da vida cotidiana, mas como um prolongamento:

\footnotetext{
"Consider instead playing as the underlying, always-there continuum of experience, as the maya-lila theory says.” (Schechner, 1995: 42)
}

Imersão e envolvimento. Essas características do fazer musical - e do jogo, em geral, para seguir Huizinga - são as principais responsáveis por permitir que o tempo para a música, inicialmente um intervalo, transborde para o resto da vida cotidiana, passando a determinar o ritmo dos dias, a preencher momentos antes vazios, a solicitar cada vez mais dedicação, a fazer da música "tudo" na vida de uma criança ou jovem.

A especificidade de uma das situações que estudei - a prática musical en- 
tre jovens internos em uma instituição - será analisada mais detidamente por revelar algumas peculiaridades da relação entre o tempo da prática musical e a temporalidade dos jovens aprendizes. A internação é uma situação limite, que, no entanto, fala muito sobre a condição do jovem de baixa renda em São Paulo, de seus desejos, expectativas e falta de opções. O que lá observei tem muito de particular, mas permite vislumbrar como a prática musical pode atuar na construção de regularidades, expectativas, ritmos e pausas nas vidas dos jovens, livres ou em situação de reclusão.

\section{Tempo em suspensão - etnografia do ruído}

betwixt and between. In an intermediate position; neither wholly one thing nor another. The American heritage dictionary

Eles têm entre 12 e 21 anos. São considerados - pela Justiça, mídia ou opinião pública - adolescentes. Alguns parecem crianças, "meninos". Outros têm no corpo - ora marcado por cicatrizes e tatuagens, ora simplesmente "adulto" - a denúncia da proximidade ou efetiva maioridade. Em comum, têm na bagagem algum ato infracional praticado enquanto ainda "menores". A maioria tem alguma estrutura familiar. Em geral, são de famílias de baixa renda. No jargão oficial, cumprem na instituição "medida sócio-educativa”. No vocabulário corrente entre os próprios - rico, aliás, em expressões e categorias - estão mesmo "presos": dormem na "cela", ficam, eventualmente, "na tranca"

A instituição em questão é o complexo do Tatuapé da Febem (Fundação para o Bem-Estar do Menor). Criada na década de 70, durante o período militar, no interior de um projeto que vinculava o problema do menor à esfera da segurança nacional, essa instituição abrigava, no período da pesquisa (1998/9), aproximadamente 1600 internos entre 12 e 21 anos, todos do sexo masculino. Os adolescentes eram divididos em 14 Unidades Educacionais (uEs) - hoje cha- 
madas Unidades de Internação (uis) - supostamente de acordo com faixa etária e a gravidade dos atos infracionais cometidos ${ }^{123}$.

Dos pontos de vista jurídico, social, familiar e mesmo etário, a condição dos jovens internos é marcada pela indefinição. Eles não têm informações sobre seu processo jurídico: uma vez na Febem, não são informados de quanto tempo ficarão na instituição. Essa desinformação leva alguns jovens prestes a serem desinternados a tentar fugir (algumas vezes, com sucesso), o que coloca em risco sua integridade física, bem como sua situação legal futura ${ }^{124}$.

$\mathrm{O}$ adolescente que chega à Febem tem, geralmente, uma condição social e familiar definida. No entanto, de formas diversas, a situação de internação pode redefini-la: as variáveis vão desde a "recuperação", com o retorno ao convívio familiar e às atividades comunitárias e a opção por "mudar de vida" (deixar o crime), até o envolvimento com atividades ilícitas de maior gravidade, "aprendidas" no contato com colegas internos. Não é incomum ouvirmos, entre os internos, a máxima: "não sei nem o que vai acontecer comigo hoje, muito menos no futuro, quando sair daqui”.

A classe etária dos internos também não desfaz a ambigüidade de seu status. Além da posição intermediária própria da condição de "adolescente”, eles enfrentam a "invisibilidade" estrutural característica dos sujeitos rituais durante o período liminar (Turner, 1970) ${ }^{125}$ : o não ser mais, não sendo ainda. Os jovens internos não são mais crianças: foram afastados do núcleo familiar, dos amigos e/ ou da escola. Ainda não são adultos: entre as atividades preferidas nos momentos de lazer da instituição estão soltar pipa, brincar e receber visitas da família; além disso, sua faixa etária lhes garante o direito de não ser responsabilizados judicialmente por seus atos com pena de prisão ${ }^{126}$. São “menores”. E o rótulo procura dissolver, na esfera das representações coletivas, o dilema da atribuição da definição "criança" para seres "sem inocência”, já que "criminosos"127. A variedade da nomeação - "Jovens infratores", “adolescentes", "menores”, "meninos" - é o reflexo da ambigüidade da situação desses sujeitos.

Por tais exemplos, é tentador pensar a situação dos internos da Febem a partir do conceito de liminaridade, com o qual Turner (1970, 1974b, 1982) 
caracteriza o momento central dos ritos de passagem ou de iniciação. Em "Betwixt and between: the liminal period in rites de passage", Turner (1970) analisa o simbolismo que envolve a persona liminar. Uma de suas características é a "invisibilidade": ela não é mais classificada e não é ainda classificada. O neófito não deve ser visto; deve ser esquecido pela sociedade. É estruturalmente invisível e ritualmente impuro. Não tem realidade social, tem que ser escondido. Ou é removido para um lugar sagrado, ou disfarçado com máscaras ou fantasias grotescas. Na condição da passagem, os iniciandos não têm status, propriedade, insígnia, roupas, posição de parentesco, "nada que os demarque estruturalmente de seus companheiros" (Turner, 1970: 98-9).

Turner ressalta, entretanto, o outro lado da condição dos iniciandos, marcada pela ambigüidade. Se, por um lado, são tornados uniformes, estruturalmente invisíveis e anônimos, por outro, adquirem um tipo especial de liberdade, um "poder sagrado" atribuído aos dóceis, fracos e humildes (idem, 1982: 26). Se não têm direitos sobre os outros, também não possuem obrigações estruturais. Apesar de estar "fora da sociedade", são estimulados a refletir sobre a mesma, por meio de informações, na forma de ritos, mitos e música que recebem dos mais velhos. Em suma, os neófitos são encorajados a pensar - e a apreender com todos os seus sentidos - sobre sua sociedade, seu cosmos e os poderes que o geram e sustentam.

"The novices are taught that they did not know what they thought they knew.

Beneath the surface structure of custom was a deep structure, whose rules they had to learn, through paradox and shock.” (idem: 42)

A comparação entre iniciandos e internos não pode ser direta. O próprio Turner (1982: 29) adverte que o uso do conceito liminaridade para processos em sociedades complexas deve ser metafórico, já que este se refere primariamente a uma fase na estrutura processual do rito de passagem, típico de sociedades de pequena escala. Além disso, há uma espécie de inversão na estrutura de sentidos dos ritos de passagem e na passagem pela Febem. 
No caso dos ritos de passagem, os sujeitos liminais seriam reduzidos a uma condição uniforme para, em seguida, serem modelados de novo, dotados de outros poderes para enfrentar sua nova situação de vida. Essa situação pouco ou não-estruturada resultaria na formação de uma comunidade de indivíduos iguais, à qual Turner denomina "communitas" (Turner, 1974). A experiência da "communitas” libera as capacidades humanas de cognição, afeto, criatividade etc. dos impedimentos normativos que derivam do status social (Turner, 1982: 44) e caracteriza-se por relações livres entre indivíduos (idem, 1974: 161; itálico meu).

A situação de internação - apesar de ser indicada como "medida sócio-educativa” - não prepara o jovem para enfrentar uma nova situação de vida. As altas taxas de reincidência (a maioria dos adolescentes tem mais de uma passagem pela instituição) revelam que, muitas vezes, ao sair da Febem o jovem volta à atividade criminal. Se a passagem pela Febem proporciona alguma "mudança de status", essa é perversa: o garoto passa a carregar em seu currículo essa "passagem”, que será mais um reforço para a exclusão social deste jovem.

Salvo em momentos bem específicos (como em algumas atividades que são a exceção e não a regra da internação), não há liberação de afeto, criatividade, e as relações entre os indivíduos são marcadas pela ausência de liberdade. Se communitas é lugar de utopia, a Febem é, para cada jovem lá interno, quase unicamente distopia.

A invisibilidade - que o interno tem em comum com o iniciando - é, no caso da Febem, outra perversão sociológica: a sociedade interna o infrator para esquecê-lo. A questão aqui não é a educação para a reabilitação do indivíduo ao convívio social, mas a proteção do conjunto da sociedade da ameaça que esses sujeitos representam. Em Hikiji \& Miraglia (2000) notamos que a internação podia ser entendida a partir da mesma lógica que rege os movimentos rápidos para fechar as janelas escurecidas do carro, desviar na rua de "gente suspeita" e o próprio descaso com a miséria, exercícios diários de esquecimento.

Os neófitos, anota Turner, são encorajados a pensar sua sociedade, a perceber sua "estrutura profunda". No modelo do autor, a communitas prepara a reintegração do iniciando na estrutura social. Na Febem a reflexão se dá em momentos 
de interrupção. Não é a proposta da instituição, mas faz-se possível nas brechas, em situações que escapam ao modelo, que, pelo "choque e paradoxo" - para ficarmos com Turner - evidenciam ao jovem sua situação. A prática musical, tal qual vivida no espaço do Guri, é uma dessas situações, como pretendo mostrar.

John Cowart Dawsey (1998) notou a filiação da teoria de Turner ao "paradigma do teatro dramático na antropologia”, o que o aproxima também de Huizinga e de sua relação com a teoria aristotélica. Tal como a tragédia descrita por Aristóteles em sua Poética, os ritos de passagem - e os dramas sociais - possuem a estrutura dramática de “começo, meio e fim”, geram "empatia”, implicam a identificação dos espectadores com os personagens e sentimentos que representam (ou, no caso dos ritos, dos atores com os papéis sociais). A liminaridade, que liberta os iniciandos da estrutura apenas para que retornem à mesma revitalizados, aproxima-se da experiência do teatro dramático que Aristóteles define como a catarse: ao provocar a piedade e o horror do espectador, a tragédia contribuiria para a purificação desses mesmos sentimentos.

A situação vivida pelos jovens internos na Febem não pode ser compreendida somente na chave dramática: nem todo conflito implica resolução, nem toda separação, "reagregação". Para seguir na analogia de Dawsey, um pouco da interrupção do teatro épico pode iluminar a etnografia neste caso. O teatro de Brecht, lembra Dawsey, "se coloca na contramão" da forma teatral aristotélica. Brecht quer interromper o teatro da ilusão. O espectador é provocado a tomar decisões (idem: 19/20). Em tal leitura, diferentemente da dramática, não há resolução: "não há um sentido final, são apenas recortes" (Barthes, 1990; apud Dawsey, op.cit.).

O conceito de gestus social é retomado por Dawsey, em sua defesa da apropriação do teatro épico como paradigma para a antropologia. Roland Barthes (idem, ibidem: 88) define o gestus social como "um gesto, ou conjunto de gestos, onde se pode ler toda uma situação social. Nem todos os gestus são sociais: não há nada de social no gesto que faz um homem para espantar uma mosca; mas, se esse mesmo homem, mal vestido, debate-se contra cães de guarda, esse gestus torna-se social; o gesto com que a dona do bar verifica o dinheiro com que lhe 
pagam é um gestus social; o grafismo excessivo da assinatura do burocrata de la ligne générale é um gestus social”. Para Benjamin, o gestus social é a "interrupção que produz o 'assombro'” (Dawsey, idem: 90). Em resumo, Dawsey define o gestus social como "o gesto ou conjunto de gestos carregados de conflitos, tensões ou contradições sociais. Trata-se de um momento de indeterminação, um instantâneo das relações sociais, um clarão capaz de fixar a imagem das contradições, assim como brechas, aberturas".

Na etnografia, a apresentação do gestus permite, ao invés de uma "descrição densa", o que Dawsey chamou de uma "descrição tensa", "carregada de tensões, capaz de produzir nos próprios leitores um fechar e abrir de olhos, uma espécie de assombro diante de um cotidiano agora estranhado, um despertar" (idem: 64). Seria o equivalente, em uma antropologia musical, da inclusão do ruído.

\section{plano seqüência}

O menino da UE7 (Unidade Educacional 7) brinca com o carrinho ganho na festa junina. [Os meninos da uE7 são bem jovens, têm até 14 anos].

Reparo em sua mão: uma tatuagem de cinco pontinhos (que já vira em outra mão...).

Parece uma das faces de um dado.

Observando que eu observo, outro menino pergunta para o tatuado:

- "Você sabe o que significa?"

- "Sei. Formação de quadrilha. Nasci para morrer, matar, roubar, sobreviver..." (perdi o significado de um dos pontinhos...)

\section{um frame}

Um garoto empunha o violino para a foto. Como uma metralhadora.

Os gestos assombram. Na primeira situação, por seu excesso de ambigüidades e indefinições. O contexto no qual se passa a seqüência descrita é uma festa junina da unidade que abriga os internos mais jovens da Febem Tatuapé. A maioria não tem 
mais de 14 anos, e foi internada por alguma relação com o tráfico e uso de drogas. São os "pedrinhas", na definição dos colegas mais velhos de outras unidades, que se referem à principal droga consumida pelos internos da uE 7, o crack.

Pude entrar na unidade no dia da festa junina para acompanhar um grupo de jovens que fazia a oficina de vídeo oferecida por Paula Miraglia e por mim. Eles decidiram, na oficina, fazer uma reportagem sobre a festa. O ambiente era, aparentemente, o de uma comemoração junina em uma escola qualquer. Havia decoração junina, barracas de jogos, música, crianças e jovens fantasiados como caipiras. Como só há meninos internados, havia, para a quadrilha, meninos vestidos como meninas. Tal inversão era vivida com algum constrangimento, mas, as “caipiras" eram os meninos mais novos e pequenos, o que colaborava para o tom de brincadeira infantil impresso à festa.

Foi em meio a esse clima que observei o menino tatuado. Ele brincava com a prenda recém obtida em uma barraca. Devia ter 13 anos. Brincava de carrinho. Cinco pontinhos em sua mão... História e estigma impressos no corpo. A forma como são explicados faz necessário acrescentar que são também “elogios”, como os acumulados no corpo pelo guerreiro tupinambá:

\footnotetext{
"Seus nomes eram acompanhados de elogios, verdadeiros epigramas escritos não no papel, nem no bronze, nem na casca das árvores, mas na própria carne. Rosto, ventre e coxas eram o mármore sobre os quais mandara gravar a história de sua vida, com caracteres e figuras estranhas...” (Abbeville, 1975 [1614]: 268; apud Carneiro da Cunha \& Viveiros de Castro, 1985/65: 62)
}

Também vi nos cinco pontinhos uma das faces de um dado. A vida como jogo. De azar. Lampejos...

O segundo gestus persiste - assombroso - como imagem, frame. É uma foto de jornal. A reportagem fala de resultados da introdução do projeto musical na Febem. Diminuição de fugas. A música x a violência. Acompanhando a matéria, a foto do jovem, com o rosto devidamente ocultado (com a tarja que remete 
ao universo do crime, inevitavelmente ${ }^{128}$ ). O rapaz reproduz com o violino a postura de empunhar uma arma. Se idéia própria ou sugestão do fotógrafo, não saberemos. A imagem sobrepõe representações.

\section{barulho}

25 de junho de 1999

Alto astral na casa.

Há duas semanas, os meninos estão levando os instrumentos para a unidade para estudar no fim-de-semana. Precisam se preparar para uma eventual apresentação da orquestra.

Ouço de um jovem na sala da entrada:

- Vamos fazer uma orquestra para as visitas no domingo, com Titanic e tudo.

Outro jovem retruca:

- Se fizer muito barulho na unidade, eu vou quebrar!

Outro conjunto de gestos. Mais sobreposição. Jogo de representações. Impressão, de novo, de "brincadeira". Provavelmente, ninguém quebrou nada; não deve ter havido, tampouco, a orquestra para visita. Mas há, na situação, todo o conteúdo latente proporcionado pelo projeto. Um novo saber que pode ser mostrado no dia de domingo. Um real perigo de deixar em mãos de "menores infratores" instrumentos feitos de madeira, cordas... A contaminação - barulho - que esse saber/poder dissemina na vida (silenciosa) da unidade...

pausa

Esta não é minha primeira passagem.

Estudar música ajuda a passar o tempo.

Frases comuns entre os internos da Febem

Afirmei, há pouco, que a música pode representar um momento de interrupção e até de reflexividade no cotidiano da internação. Para compreendê-lo é preciso 
retomar a análise da relação entre tempo musical, tempo de vida e tempo institucional $^{129}$.

O adolescente que chega à Febem, mesmo ignorando a duração de sua estada na instituição, sabe que está lá "de passagem”. Ao adentrar a Febem, o jovem depara-se com regras e semântica a serem aprendidas, ora impostas pela instituição, ora formuladas pela própria comunidade de internos. Para muitos, a passagem não é uma, mas um evento cíclico: ter várias "passagens” pela Febem é característico de uma parcela (grande) dos adolescentes que não consegue mais adequar seu cotidiano a uma realidade separada da criminalidade.

Outra característica do espaço-tempo da passagem é exatamente o redimensionamento do espaço e do tempo. A instituição "substitui" a casa e a rua e "fornece" o ritmo do cotidiano dos internos. Este é caracterizado por uma rotina pormenorizada, com regras que regem dos movimentos corporais às atividades cotidianas.

Michel Foucault (1988: 114), em seu clássico ensaio sobre a história das prisões, aponta a imposição institucional da rotina como um instrumento de punição no qual o alvo "é o corpo, é o tempo, são os gestos e as atividades de todos os dias". "Horários, distribuição do tempo, movimentos obrigatórios, atividades regulares, meditação solitária, trabalho em comum, silêncio, aplicação, respeito, bons hábitos" são os instrumentos que constituem a técnica que tem por fim não a correção do "sujeito de direito, que se encontra preso nos interesses fundamentais do pacto social”, mas a constituição do "sujeito obediente, o indivíduo sujeito a hábitos, regras, ordens, uma autoridade que se exerce continuamente sobre ele e em torno dele, e que ele deve deixar funcionar automaticamente nele".

A observação da Febem revela essa apropriação punitiva do tempo, distribuído em tarefas institucionais. A rotina institucional é baseada no controle das atividades e do próprio corpo do interno: fumar, ir ao banheiro, ficar em pé ou sentado são exemplos de gestos vigiados. O tempo nas Unidades Educacionais é dividido em momentos com atividades (escola, trabalho, faxina, banho e alimentação, por exemplo) e tempo ocioso, ou, nas palavras dos internos, "ficar no pátio". 
No pátio, os jovens são obrigados a passar a maior parte do tempo sentados. Para ir ao banheiro, é preciso a autorização de um monitor, que é responsável por garantir a ida de apenas um interno por vez e pelo controle do tempo gasto. É também o monitor quem autoriza que o interno cruze o pátio para falar com um colega, ou ainda que ele se levante para acender o cigarro (é o monitor quem possui o isqueiro). Enfim, o pátio simboliza o máximo controle institucional e, do ponto de vista dos internos, sintetiza a situação de opressão.

Erving Goffman, em sua análise sobre as instituições totais ${ }^{130}$, afirma que a obrigação de pedir permissão ou instrumentos para atividades secundárias que a pessoa pode executar sozinha no mundo externo, como as descritas no caso da Febem (fumar, ir ao banheiro etc.), é "uma das formas mais eficientes para perturbar a 'economia' de ação de uma pessoa” (idem: 44). Submissão e humilhação são os resultados mais evidentes desse processo de pormenorização e controle da rotina.

\section{gestus em trítono}

"Daí a gente acorda, tem que pegar a linha do boi, daí a gente toma café, daí tem que fazer o procedimento... depois a gente pode pagar a brasa.”

Interno na Febem

“As cascas de pão só podiam ser deixadas do lado esquerdo do prato.”

Regra de cadeia para adultos

“O desenho dos lençóis deveria ficar paralelo à beirada da cama, os travesseiros em ângulo reto."

Descrição de campo de concentração ${ }^{131}$

O tempo no pátio "não passa”. É preciso "matar o tempo". Uma das formas de fazê-lo é conseguir participar das atividades educativas, obrigatórias ou opcionais, oferecidas pela Febem. Apenas a escola (ensino fundamental ou médio) é obrigatória. No "circuito grave”, as aulas são dadas dentro da própria unidade. 
Havia, na época da pesquisa, no complexo do Tatuapé da Febem, uma escola exterior às unidades ${ }^{132}$, que podia ser freqüentada por alguns jovens do "circuito médio". Entre as atividades opcionais, estão os cursos profissionalizantes (ministrados por funcionários ou em parceria com o SENAI) como marcenaria, computação, mecânica, culinária, tecelagem, horta; as atividades esportivas e as artísticas, dentre as quais o Projeto Guri (que oferecia aulas de violino, viola, violoncelo, baixo, violão, percussão e canto coral, em uma casa destinada apenas a essas atividades).

A participação nos cursos opcionais depende, em geral, da indicação da direção de cada unidade, que determina quais adolescentes poderão freqüentar as atividades, conforme avaliação de conduta e histórico individuais. Os internos que "causam problemas" na unidade (brigam, participam de tentativas de fuga, ou enfrentam funcionários) dificilmente participam dos cursos. Qualquer comportamento considerado indevido pode "retirar" os jovens das atividades. Esse fato, aliado às desinternações e fugas, faz com que a freqüência nos cursos de maior duração seja bastante irregular. De certa forma, os internos também passam pelas atividades, muitas vezes, sem concluir o que seria um processo de aprendizado.

A ocupação do tempo é também um dos principais objetivos da atual política institucional da Febem. Em outubro de 1999 a Febem viveu um de seus piores momentos, quando uma rebelião de três dias, envolvendo mais de mil dos 1.300 internos, culminou com a morte de quatro jovens, um deles decepado pelos próprios internos. Segundo a administração da Febem, um dos estopins dessa rebelião teria sido justamente a “ociosidade” dos jovens lá internados. A Imigrantes deveria ser uma unidade de triagem, na qual os adolescentes aguardariam por, no máximo, 45 dias, o resultado de seu processo judicial. Por isso, não havia uma preocupação em ocupar o cotidiano desses internos. No entanto, esse prazo não vinha sendo respeitado e, conseqüentemente, os jovens passavam até meses largados, sem nenhuma atividade. Nesse caso, a situação do "pátio" vinha sendo levada ao extremo: sem ocupação nenhuma, os jovens viviam a situação de ócio vigiado, degeneração da noção de tempo livre, na qual a ausência de atividades 
programadas não implica as possibilidades de lazer e individualidade, mas um tempo não preenchido vivido sob uma tutela institucional onipresente.

De acordo com os meninos, nesses momentos de ócio controlado "pesa a cadeia”. O "pátio" faz pensar no tempo não vivido - em tudo que está do outro lado das grades institucionais, ou, em suas palavras, no "mundão". Talvez por isso eles contem que lá se pensa sempre em fugir.

Kiko Goiffman, que analisou o cotidiano de prisões masculinas no Estado de São Paulo, percebe nesses contextos relação semelhante do preso com o ócio: "ao menos como discurso, [o ócio] é valorizado negativamente por todos os atores sociais envolvidos no cotidiano carcerário e também pela sociedade” (Goiffman, 1998: 115). Cita Lúcio Flávio - "a cabeço do preso é a oficina do diabo” - e diz: “Ocioso, o preso dispõe de ‘todo o tempo’ para planejar fugas, revoltas" (idem: 113). O tempo na prisão é encarado como "tempo perdido": "muitas vezes as tentativas de fuga são justificadas como uma busca do tempo perdido na prisão e a delação que leva o plano ao fracasso, um 'atraso'” (idem: 114).

Erving Goffman analisara as características desse "tempo perdido". Para o autor, o tempo nas prisões e hospitais para doentes mentais é algo que foi "posto entre parênteses". O internado tende a se sentir "exilado da vida”. Especialmente desmoralizadora é, para Goffman, a influência de uma "sentença indefinida", tal qual ocorre na Febem.

"Entre os internados [...] existe um intenso sentimento de que o tempo passado no estabelecimento é tempo perdido, destruído ou tirado da vida da pessoa; é tempo que precisa ser 'apagado'; é algo que precisa ser 'cumprido', 'preenchido', ou 'arrastado' de alguma forma.” (Goffman, 1974: 64/ 5; itálicos meus)

É comum destacar-se, nas análises sobre instituições totais, o papel da recreação / lazer como atividade para "passar o tempo". Goffman ressalta inclusive a importância atribuída às chamadas atividades de distração, que, para ele, são "intencionalmente desprovidas de seriedade, mas suficientemente excitantes para 
tirar o participante de seu 'ensinamento', fazendo-o esquecer momentaneamente a sua situação real" (idem, ibidem; itálicos meus). Os exemplos - jogos ao ar livre, bailes, participação em orquestras ou bandas de música, coral, aulas, ensino de arte - remetem imediatamente ao caso do Projeto Guri, na Febem. Uma análise mais detida, entretanto, conduz ao questionamento dessa avaliação. Como já observei no capítulo anterior, as situações vividas pelos participantes do Guri na Febem não permitem falar em esquecimento, mas, como pretendo detalhar, em reflexividade.

\section{passatempo fuga subversão}

No pólo Febem, o Projeto Guri teve início em julho de 1996, atendendo a 70 meninos. Esse foi o segundo pólo do Guri e sempre obteve muito destaque na mídia em função de suas peculiaridades: era o único a ensinar "música de orquestra" para "menores infratores"133. Entre 1996 e 2000, cerca de mil adolescentes passaram pelo pólo Febem. Em abril de 2000 a Secretaria de Cultura suspendeu as atividades na instituição ${ }^{134}$. Em 2002, algumas atividades do Guri foram retomadas, sendo realizadas no interior das Unidades Educacionais e também em outros pólos da Febem, como o internato feminino no Brás. No fim de 2003, em meio à discussão sobre a diminuição da idade penal e aos projetos do governador Geraldo Alckmin de aumento do tempo de reclusão de jovens envolvidos em crimes violentos, o governo do Estado anuncia a extensão das atividades do Projeto Guri para todas as 70 unidades da Febem ${ }^{135}$.

Entre 1998 e 1999 - época em que realizei a pesquisa na Febem - os alunos costumavam freqüentar duas aulas por semana (de instrumentos ou coral). As aulas eram em grupos, que variavam entre dois e cerca de 20 alunos. A entrada de um novo aluno acontecia quando surgiam vagas devido a desinternações ou fugas de alunos. A coordenação do projeto comunicava a abertura de vagas à direção das unidades (uts) e ficava a critério dessa a seleção dos internos que poderiam participar. Os critérios para a seleção eram os mesmos utilizados para os cursos profissionalizantes. A avaliação do comportamento era levada em conta. 
Observei que alguns internos participavam de várias atividades, enquanto outros nunca saíam das unidades. A prática musical era assimilada ao sistema de privilégios e castigos fundamentais à organização das instituições totais (cf. Goffman, 1974), como fica evidente nessa entrevista com Rosemary dos Santos, assistente técnica para Projetos Especiais da área de cultura da Febem, realizada em maio de 2000.

Pergunto: No caso do Guri, como funcionava, quem podia participar?

Rosemary: Por interesse. As atividades eram divulgadas dentro das unidades.

P: E como era essa seleção?

R: Não sei. Não tinha controle sobre isso. A unidade trazia, a gente fazia uma demonstração dos instrumentos, aí depois de uma semana de curso, eles eram matriculados.

P: Os critérios de seleção, você não sabe?

R: Acho que a unidade usava muito a questão do comportamento. E quando chegava aqui a gente fazia uma outra seleção de interesse.

P: Parece que alguns meninos faziam várias atividades e outros não faziam nada...

R: É isso, só que esse controle nós não tínhamos.

P: Isso mudou?

R: Não.

P: Mesmo com vocês dentro da unidade, é a unidade quem decide quem participa ou não? [em 2000, os professores de música passaram a dar aulas dentro das Unidades Educacionais, em vez dos jovens irem até a sede dos Projetos Especiais]

R: Isso.

Uma característica do Guri que é mantida no pólo Febem é o contato imediato com o instrumento e o rápido acesso a um repertório erudito e popular com arranjos simplificados. Ao interno não são, geralmente, oferecidas muitas opções de instrumentos (o que difere dos demais pólos). "Me perguntaram se eu queria aprender violino. Eu nem sabia direito o que era isso, mas fui. Pensei: é melhor que ficar na unidade”, conta um jovem. Uma vez no projeto, o interno pode ten- 
tar mudar de curso, ou desistir. A taxa de desistência não é alta, mas a freqüência era muito variável em virtude de desinternações, fugas ou do próprio sistema de privilégios e castigos, que punia maus comportamentos com o corte do aluno das atividades do projeto.

A rapidez de acesso ao instrumento e a um repertório musical é apresentada como estratégia pedagógica, embora eu tenha observado que, muitas vezes, a estratégia obedecia a interesses menos educativos que políticos. O Projeto Guri era, em 1999, um dos produtos exibidos como "vitrine" da área cultural do então Governo Covas - e continuou sendo para o Governo Alckmin. Várias vezes, com o objetivo de preparar os alunos para uma apresentação pública institucional (que tem como objetivo apresentar o próprio projeto em um evento maior, como o Festival de Inverno de Campos de Jordão), eram realizados ensaios e aulas extras, com uma carga horária bem maior que a normal. Passados os eventos, as aulas voltavam ao ritmo normal.

Apesar do óbvio interesse político, a mudança no ritmo dos ensaios e aulas surtia efeito positivo para os alunos do projeto na Febem. No tempo marcado pela repetição, pelo ritmo ditado pela instituição, a intensificação das horas de aula e, sobretudo, de ensaios, correspondia a uma quebra na rotina. Como nota Goiffman (1998: 116), se a redundância é regra no tempo na prisão, há “uma certa expectativa de instabilidade. A novidade e a quebra do tempo aparecem como promessa, [...] rompem o ciclo dos dias que é retomado a seguir".

Também a percepção de que estavam trabalhando com algum objetivo - ensaiar um repertório para apresentação - estimulava os jovens, que, como já observado anteriormente, manifestavam um surpreendente interesse, concentração e vontade em aulas de até quatro horas de duração.

Quando questionava os jovens sobre o porquê de estudar música na Febem as respostas sempre começavam com a justificativa da "fuga do pátio". Ficar na Unidade "parasitando", sem fazer nada, não ajuda a "matar o tempo". No pátio, "parece que o tempo não passa, parece que o tempo fica parado", resume um dos jovens. Mas ao lado da necessidade de "matar o tempo", surgia, com o início da prática musical um "gostar” pouco entendido pelos próprios meninos. 
“Ele fazia aula comigo e um dia me perguntou: 'Professora, por que eu não consigo parar de pensar no violoncelo?'. Respondi que era porque ele estava gostando de aprender. Para eles, não era muito normal gostar de alguma coisa."

Luciana Rosa, professora de violoncelo e contrabaixo no pólo Febem

Dawsey (1998: 37/8) propõe que invertamos a proposição de Geertz, de transformar o exótico em familiar. Sugere que, com Brecht, mostremos que o "lugar familiar" é, na verdade, um "lugar distante", estranho. Apontar o familiar como exótico, seria o primeiro passo para provocar o efeito de distanciamento, base didática do teatro de Brecht. Somente com essa inversão é possível entender a situação acima descrita. Ao aluno, interno na Febem, gostar de alguma coisa (algo familiar para nós) é muito estranho, quase incompreensível. À professora, o estranhamento do aluno causou espanto - tanto que ela assim narrou o fato para mim. Cabe notar, que, à época, eu também era sua aluna, e gostar de um instrumento ou de música era para mim algo completamente "natural". Assim, em vários níveis, a música provocou a interrupção necessária para qualquer processo reflexivo.

"Comecei a tocar só para sair da unidade, mas agora eu estou gostando mesmo". A frase, comum entre os internos participantes do Guri na Febem, ecoa o exemplo anterior. No capítulo 3, comentei as aulas de até quatro horas de duração que presenciei na Febem. Eram grupos de 10, 15 adolescentes iniciantes em um instrumento de orquestra, que permaneciam, durante todo esse tempo, concentrados, atentos à partitura, trocando informações e dúvidas, mesmo enquanto o professor se ausentava da sala. Não era possível aceitar o "matar o tempo" como a justificativa para tal participação no projeto.

Conhecendo as peculiaridades do estudo musical - que é repetitivo, envolve resistência física e psicológica, não apresenta resultados imediatos - eu sabia que aulas de quatro horas de viola ou violino poderiam ser tão longas quanto as horas no pátio, caso não houvesse um real interesse na atividade. O que observei, entretanto, era um grupo de jovens experimentando as sensações de se fazer 
música em grupo: sentimento de conjunto, concentração, cooperação, comunicação, superação de dificuldades, autoconfiança, prazer. O tempo não estava sendo "morto", mas vivido intensamente.

Essas características do fazer musical são extensíveis aos demais pólos do Guri, e à prática musical em grupo, em geral. A especificidade do pólo Febem está justamente na maneira como se dá o trânsito entre o "passatempo" e o "gostar mesmo" na prática musical. Há, na vida institucional, o peso insuportável do ócio vigiado. Esse tempo, é preciso "matar". A música é chamada para tal. Mas não só: o que diferencia a prática musical no pólo Febem é que ela instaura conhecimento e desejo em corpos sem liberdade.

A prática musical demanda uma preparação muito específica do corpo. É preciso aquecê-lo para a música. Alongamentos podem ser realizados nessa preparação. Tensões são indesejáveis tanto para a prática do canto como de um instrumento. É preciso estar relaxado. É impossível fazer música - sobretudo em grupo - sem muita concentração e sintonia entre os músicos. É necessário estar disposto para lançar corpo e mente em uma sessão de uma ou várias horas de estudo musical.

$\mathrm{Na}$ Febem, durante as aulas ou ensaios do Guri, a relação dos internos com as regras, ritmos e obrigações institucionais passavam por mudanças: nas aulas, os jovens não eram "vigiados" por monitores, sentavam-se ou levantavam-se de acordo com sua vontade ou com a necessidade imposta pela atividade. Freqüentemente eram levados a observar seu corpo, sua postura, suas tensões. Nesses momentos, evidenciava-se o conflito entre o corpo do interno e o corpo para a música. Por vezes, ouvi os jovens comentarem com seus professores que estavam "quebrados". Além dos castigos corporais - que são ainda comuns na Febem pode-se pensar que o corpo "quebra" quando tem seus movimentos tolhidos. As posturas obrigatórias - cabeça baixa, mãos para trás, andar ritmado - marcam o corpo do interno, ao restringir seu repertório de movimentos à coreografia da submissão. A música introduz elementos dissonantes nessa coreografia. Solicita leveza, força, delicadeza, relaxamento. A experiência musical acorda os sentidos, "faz esquentar o sangue". 
Por que você decidiu aprender violino? - perguntei a um jovem interno.

- A senhora já viu um desses aqui na rua? - retrucou.

O trecho de conversa é significativo. Sempre que expus o conteúdo do projeto que eu analisava nesta pesquisa, fui questionada sobre o porquê de se ensinar instrumento de orquestra, repertório erudito, para jovens que nunca tiveram nem viriam a ter contato com este universo. Tentativa civilizatória, diriam alguns. Aculturadora, outros. A fala do jovem revela, no entanto, uma apropriação diversa do conteúdo oferecido. Para aquele menino, não interessava aprender cavaquinho ou violão, também oferecidos pelo Guri no pólo Febem. Esses instrumentos, ele conhecia da rua, das rodas da vizinhança. A oportunidade de aprender violino, era, para ele, uma forma de acesso a um conhecimento exclusivo, que lhe interessava porque diverso do que ele acessava na rua. Era, no limite, uma forma de diferenciação tanto no interior da Febem quanto no "mundão".

Fazer música pode corresponder, portanto, à afirmação de uma diferença. Jovens presos estudando violino são uma imagem que se destaca, causando até reações adversas dentro e fora da Febem. De um funcionário da Febem, por exemplo, ouvi um longo discurso sobre a importância da profissionalização (por meio dos cursos de capacitação) do jovem interno para sua readaptação à sociedade e uma frase curta e grossa sobre o Guri: "isso é ilusão!”. Comentário que não se distancia do raciocínio de uma senhora indignada com a "inutilidade" do ensino musical para "bandidos": "tem que ensinar a trabalhar".

No início da tese (capítulo 1), observei, com Zaluar (1994), que o ócio - e sua associação com o lazer, o esporte e as artes - é "permitido" às classes abastadas, mas o acesso aos bens culturais e artísticos não é visto ainda como direito de todo cidadão, apesar de garantido no plano legal no Brasil. Uma inversão nesse cenário se dá quando, nos mais diversos contextos - na Febem, na periferia ou nos bairros nobres da capital - surge a necessidade de ocupação do tempo ocioso, que passa a ser visto como um potencial estimulador da desordem 
(da rebelião, na Febem; do ingresso no universo do crime, das drogas, nas ruas da cidade). Ninguém questionaria a decisão de uma família de classe média de matricular seu filho em uma escola de música. Isso faz parte, historicamente, da formação das crianças e jovens das famílias burguesas. Mas o ensino de música para crianças pobres, para jovens "presos" causa estranhamento e até repulsa. Quando a música é tocada em instrumentos de orquestra - pouco acessíveis até para as classes mais abastadas - o estranhamento é ainda maior.

$\mathrm{Na}$ Febem, as diferenças explodem. A música sobrepõe a lógica do tempo livre - não liberado - à do tempo institucional (tempo do preso). Nesse sentido, pode ser subversiva ${ }^{136}$. Oferecida à "menores infratores", põe em risco a ordem que separa os universos do trabalho e do lazer, da punição e da diversão, de presos e libertos, do popular e do erudito, de pobres e ricos. 


\section{CONSIDERAÇÕES FINAIS - [DE]COMPOSIÇÃO}

\section{Da pesquisa da performance à performance da pesquisa}

Richard Schechner (1985), um dos principais pesquisadores da performance a partir da antropologia, nota a situação teatral desencadeada pela presença do pesquisador em campo: ele está lá para ver, e ele é visto. Sua presença "é um convite à atuação". O que o diferencia dos demais performers é sua ambigüidade. Ele é um "não performer" e um "não-não performer”; não é um espectador, nem um não-espectador. Ele está entre (“in between”) dois papéis, assim como entre duas culturas. No campo, ele representa - querendo ou não - sua cultura de origem; de volta para casa, representa a cultura que estudou.

Quando fui a Campos de Jordão, cidade turística de São Paulo, com um grupo de jovens internos na Febem, para acompanhar sua apresentação no Festival de Inverno, eles me perguntaram se eu era repórter. Tentei explicar a diferença entre a pesquisa e o jornalismo, ofício que, aliás, exerci alguns anos atrás. Basicamente, disse que o repórter vinha, passava pouco tempo com eles, perguntava algumas coisas e depois escrevia ou falava como se soubesse tudo sobre eles, sobre sua situação na Febem etc. Expliquei - para eles, para mim... - que na pesquisa, a idéia era observar por mais tempo, ouvir muito e só depois escrever alguma coisa... Para completar, eu poderia ter dito que, na pesquisa, depois de tudo, a impressão é a de que pouco sabemos de fato sobre eles, mas sim de nossa relação. 
Como se pôde ver, essa relação nem sempre foi tranqüila. Em vários momentos, foi marcada por desconfiança (eles em relação a mim), diferença (eu-"playboy"; eles-periferia), medo (eu em relação a eles), mal-estar (meu e deles com a instituição). Por vezes, felizmente, correspondeu a uma efetiva troca (como nas oficinas de vídeo, nas reportagens em que eram "meus" repórteres, na coxia...).

Mas tornar compreensível o que significava para ele essa última, essa canção, a velha Tília, é realmente empresa das mais complexas, que requer de nossa parte um tratamento de extraordinária delicadeza, porque o contrário nos levaria antes a comprometer do que a esclarecer a questão. Thomas Mann, A Montanha mágica

O cuidado que o narrador d' A Montanha mágica dedica à descrição da relação do protagonista do romance com determinada música deveria servir como premissa - no mínimo, um alerta - ao projeto que tentei empreender. Que sorte de onipotência é essa, que fez um dia esta pesquisadora acreditar ser possível desvendar os significados do conhecimento musical para todo um grupo?

Certo dia, mais de três anos após o início da pesquisa, me surpreendi questionando jovens de 14, 15 anos, que tocavam violão havia menos de um ano, sobre o significado da música na vida deles. Os rostos, imóveis diante da curiosidade insólita, eram antes - agora percebo - pequenas trincheiras, obstáculos para impedir o acesso alheio à intimidade do exercício por vezes solitário da descoberta musical. Tantos confessaram tocar sozinhos, "para mim mesmo”...

Teria eu confessado - a um pesquisador, a mim mesma - o significado das quase três horas diárias em que ficava trancada num quarto, com um violão, algumas partituras e canções, durante anos de minha infância e adolescência? Saberei eu racionalmente explicar como e porque, a menos de um mês do prazo para depositar esta tese, aceito integrar uma orquestra de estudantes para montar uma ópera de Mozart com dois ensaios por semana de três horas cada? 
What right does anyone have to record what we choose to forget?

Carpenter (1973, apud Feld, 1992) conta que durante a projeção do filme Dead Birds ${ }^{137}$ (Robert Gardner, 1963), em Papua Nova Guiné, um jovem desligou o projetor e proferiu a frase acima: o filme negava-lhes o direito ao esquecimento.

Como apontei em alguns momentos desta tese, o esquecimento é a sentença à qual são condenados os jovens "em conflito com a lei” que vão parar na Febem. Falar, encenar, criar situações para o vídeo são, para eles, formas de superar, por alguns instantes, essa condição.

Desde Jean Rouch, o "antropólogo-cineasta" que provocou o cinema de meados do século xx com inovações éticas e estéticas ${ }^{138}$, a câmera configura-se como uma potencial facilitadora da comunicação com o grupo pesquisado. O conhecimento obtido por meio da "câmera participante" não é - ou não deveria ser - um segredo roubado, mas um processo de troca. O filme (ou vídeo) não é tampouco pensado no registro documental - aquele que quer resgatar, salvar da extinção culturas em “processo de desaparecimento" - mas, é, para Jean Rouch, uma efetiva possibilidade de compartilhar com o grupo a produção de um conhecimento sobre si.

Desde a década de 40 até hoje, Rouch vem produzindo dezenas de filmes com o intento de estabelecer um diálogo efetivo com a sociedade estudada. Esse, o princípio da "antropologia compartilhada", seria permitido, de forma ímpar, por meio do filme. O cineasta, pesquisador de grupos africanos que, em sua maioria, não liam, vê no filme a possibilidade de levar sua análise sobre o grupo de volta para o mesmo. O retorno inclui, geralmente, no trabalho de Rouch, a participação efetiva do grupo na (re)elaboração do filme, seja como co-autor do roteiro, seja com observações que permitirão ao cineasta rever sua montagem ${ }^{139}$.

A experiência de pesquisa em um contexto urbano - e com jovens que estão na escola e, portanto, sabem ler e escrever - não torna menos válida a idéia de uso do filme como forma de retorno dos conhecimentos produzidos às populações pesquisadas. A linguagem audiovisual - mesmo se não convencional 
- é mais acessível que o texto, sobretudo o acadêmico.

\begin{abstract}
"O filme pode ser exibido às pessoas, que podem assim discuti-lo e ter acesso ao que lhes foi sucedido. Por pior que seja o filme, ele lhes permitirá refletir sobre si mesmos e lhes dará uma oportunidade de se ver de uma certa distância. [...] Na maioria dos casos, uma pesquisa só traz recompensas para o investigador e para a ciência em abstrato. No nosso caso, é possível obter tudo aquilo e também benefícios para as pessoas." (Jean Rouch, em entrevista a Dan Georgakas, Udayan Gupta e Judy Janda, apud Sztutman (no prelo), trad. do autor)
\end{abstract}

Finalizei dois vídeos durante esta pesquisa. Outros foram imaginados, iniciados, esboçados. O vídeo foi, como discuti na Abertura, parte constitutiva do processo de construção do conhecimento. A captação de imagens e sons foi um efetivo instrumento de comunicação com os jovens e a edição dos vídeos, um processo reflexivo à parte.

No entanto, apesar de ter captado imagens durante todo o processo de pesquisa, só consegui editá-las no fim do doutorado. Medo da técnica? Desconfiança quanto ao material captado? O fato é que houve um grande hiato entre a captação e a edição dos vídeos. Se, por um lado, isso me permitiu realizar os vídeos quando já possuía uma interpretação sólida do material etnográfico, por outro, a distância temporal não permitiu que eu explorasse todas as possibilidades de troca e criação a partir do vídeo. Não pude encontrar parte importante dos jovens que participam de Microfone, senhora: vários não estavam mais na Febem, seu paradeiro era desconhecido. Para alguns interlocutores, só pude exibir o material já editado. Não pude discutir possibilidades de edição, como conteúdo, forma, ritmo, que poderiam resultar em não apenas um vídeo diferente, mas em um conhecimento ímpar desses pesquisados, da forma como se vêem, como gostariam de ser vistos, como analisam as imagens de si criadas por outros. Enfim, o processo de troca para e a partir do vídeo, a "antropologia compartilhada" de Jean Rouch, não foi explorado em todas as suas possibilidades ${ }^{140}$. 
Eu EDITO quando escolho meu objeto [dentre milhares de possiveis objetos].

Eu EDITO quando eu observo (filmo) meu objeto [para encontrar a melhor opção dentre milhares de possíveis observaçães...]

Dziga Vertov

O cineasta Dziga Vertov defendia, nos anos 1920, o "cinema verdade". Não a "verdade no cinema", mas a "verdade do cinema". "Verdade particular" (apud Rouch, in Colleyn, 1995: 68). Vertov identifica a edição em todo o processo de produção de imagens (desde a escolha do objeto até a própria filmagem). Sua percepção nega qualquer neutralidade do observador / cineasta. Todo olhar está impregnado com sua história.

Houve um momento na história do filme etnográfico em que se pensou a câmera como um instrumento de medição e registro do real. O tripé, o zoom - acreditava-se - eram instrumentos que permitiam a observação e o registro da situação pesquisada com a mínima interferência do observador.

Não é possível, nos anos 2000 - como já não o era há duas ou três décadas - falar em um olhar neutro para a situação pesquisada, nem em um registro objetivo. Os filmes ou vídeos etnográficos, em sua maioria, são pensados como meios de interpretação da situação pesquisada ou mesmo de intervenção. Esse é o caso, por exemplo, do projeto Vídeo nas Aldeias ${ }^{141}$, no qual o antropólogo leva o vídeo para a aldeia, capacita indivíduos do grupo na captação e edição das imagens, e observa os processos de comunicação aí desenvolvidos (dos índios entre si, com outras etnias e com os brancos).

A produção de imagens nesta pesquisa foi instrumento de interpretação e de intervenção. Produzi imagens sobre e com os sujeitos pesquisados. Os vídeos realizados são, sem dúvida, construções a partir do universo observado e das performances criadas para a câmera. Levar a câmera de vídeo para a Febem ${ }^{142}$ ou para as apresentações musicais dos jovens de outros pólos do Guri é também uma possibilidade de intervenção. Os jovens de baixa renda, internos ou não, 
são, tradicionalmente, marcados pela invisibilidade. Há poucos canais de expressão, comunicação, veiculação de suas idéias e valores. Nos vídeos realizados, os jovens de alguma forma comunicam-se: veiculam imagens e representações de si, fazem-se ouvir por alguns momentos.

Posso dizer que o objetivo principal de Microfone, senhora e Prelúdio é ainda a comunicação de um conhecimento sobre o outro (a etnografia) por meio do vídeo. Mas há mais.

Steven Feld, etnomusicólogo que estudou os Kaluli, em Papua Nova Guiné, comenta, no fim de seu livro Sound and sentiment - Birds, weeping, poetics, and song in Kaluli expression, a importância de ter realizado a fotografia de um Kaluli com vestimenta de pássaro durante um ritual. Enquanto as análises e interpretações envolvem "símbolos sobre símbolos, camadas de representação", a fotografia seria "uma metáfora sobre uma metáfora”. Fazer sua própria presença afetiva ("affecting presence") ${ }^{143}$ de um mito Kaluli foi uma forma de envolvê-lo, por meio de uma experiência sensível ("feelingfull experience"), "no processo de descoberta de como a forma encarna sentimento" (Feld, 1982: 236; trad. minha).

O vídeo - e sobretudo seu processo de edição - permite experimentar descoberta semelhante à descrita por Feld. O processo de imersão que caracteriza a decupagem (anotação minuciosa do material gravado), a seleção de trechos e a montagem do vídeo resulta em uma relação ímpar com as imagens e sons captados. Uma fala, um gesto, uma expressão, antes indiferentes, passam a criar sentidos quando aproximados. Alterações na velocidade da imagem, inserções sonoras, sobreposições de situações distantes temporalmente são alguns dos recursos que dispomos para criar algo que não é apenas interpretação ou intervenção, mas, propriamente, insight e criação. Feld questiona o estudo de sistemas estéticos sem "uma preocupação com um intento estético na postura analítica" (idem, ibidem). O vídeo etnográfico é uma forma de exposição da sensibilidade estética do analista. 


\section{Do malandro ao bom sujeito}

No primeiro capítulo, comentei a análise que Bruno Nettl fez da concepção que seus colegas acadêmicos tinham sobre música. Para eles - e aos norte-americanos em geral - a música seria sempre associada a algo "bom": deve ser "bom” para um som - ou mesmo para uma falta de som (silêncio) - ser aceito potencialmente como um componente musical. Sons que são "bons" são sons que podem ser incluídos em música. Várias expressões associam o que é desejável/agradável com a esfera musical: o tilintar de moedas é "música para meus ouvidos"; uma pessoa de fala agradável tem uma "voz musical”; uma língua que não soa bem é chamada de "não musical” (Nettl, 1983: 17).

Tal visão "positiva” da música é compartilhada na sociedade brasileira. "Quem canta seus males espanta" é ditado e sabedoria popular. As expressões citadas por Nettl também nos são comuns. Quando questionava os jovens aprendizes de música do Guri sobre o significado da música, ouvia com freqüência: “música é paz”, "harmonia”, "felicidade”, "música me tranqüiliza”, "me acalma”. As respostas destacavam as qualidades "terapêuticas" da música, e eram consonantes com o próprio discurso do Guri e de outros projetos de intervenção social, que costumam destacar o caráter pacificador e terapêutico da prática musical. Cabe notar que tal visão não é exclusiva dos projetos. Sua matriz pode ser encontrada no pensamento grego. Para Platão, música e política estão intimamente relacionadas: a harmonia sonora metaforiza e condiciona a harmonia da Polis.

Há mais. A música está "no sangue” de nossa gente. Quem não gosta de música (de samba, pelo menos), "bom sujeito não é". Estar "afinado" ou "em sintonia" com alguém denota a proximidade entre as pessoas. Todos querem viver "em harmonia”. Um elogio com segundas intenções é uma "cantada”. Os exemplos tirados da "boca do povo" são representativos dos lugares atribuídos 
à música no senso comum do brasileiro. Neles, é revelada uma imbricada teia de sentidos que une história, raça, preconceito e classe social, para ficarmos nas camadas mais evidentes.

O verso musical que de tão cantado ganhou status de ditado popular - "quem não gosta de samba, bom sujeito não é" - pode ser ouvido, de modo diacrônico, como uma espécie de "resposta" ao "desafio" da elite e do clero paulista que, no início do século xx, chamava o mesmo samba de "manifestação de homens vadios e perigosos" (Contier, 1988: xxxıx). "Bons sujeitos" não eram, então, os músicos e freqüentadores das rodas de samba, música dita "dos pretos", associada à pobreza, à promiscuidade, à malandragem, às práticas mágicoreligiosas condenadas pelos "bons" costumes da época, ou seja, "além de algo socialmente vergonhoso e reprovável, também, e por isso mesmo, catalogada legalmente como 'caso de polícia”" (Borges Pereira, 2001 [1967]: 211).

João Baptista Borges Pereira, ao analisar a inclusão do negro no sistema radiofônico a partir do final dos anos 1930, descreve o processo pelo qual a música negra e principalmente o samba - e os músicos - passam a ser aceitos pela elite branca. O crescimento da atividade radiofônica teria sido um dos principais responsáveis pela aceitação da música "negra" por setores diversos da população. Aos poucos, a música passou a ser um trabalho para muitos dos músicos antes marginalizados. Atividades como a de professor de violão - instrumento antes repudiado nas casas de "família" - passam a ganhar espaço, e o negro passa a dar aulas para as moças da elite carioca.

Porém, se a música era uma porta de entrada para o profissional negro nas casas da elite, essa não era, obviamente, a "porta da frente". Borges Pereira nota que a aceitação e valorização do negro como músico ou radialista profissional não é acompanhada de sua inserção nos eventos sociais freqüentados quase exclusivamente por brancos. "Diferentemente do que se dá com o artista branco, o convite [para o artista negro participar de uma recepção em residência particular] é sempre ao profissional, nunca ao indivíduo. E naquela qualidade espera-se que ele dê demonstrações de suas habilidades artístico-profissionais sem se prevalecer da oportunidade para usar as prerrogativas reservadas ao 'autêntico' convidado.” 
A análise de Borges Pereira esclarece outras idéias do repertório do senso comum brasileiro: a de que a música está "no sangue” de nossa gente e a de que negros e pobres só “vencem” na música e nos esportes - atividades, aliás, mais associadas à esfera sensível que à racional.

\begin{abstract}
"é inadmissível a existência de pessoa que ponha em dúvida que 'nas veias do negro corre sangue misturado com ritmo', que ele traga em seu sistema neuro-muscular toda aquela predisposição para os requebros e para a 'ginga', enfim, que a improvisação, 'a bossa' e a 'malícia' - elementos tidos como indispensáveis para a interpretação de nossa música popular - não sejam qualidades inerentes à sua própria constituição biopsicológica. Tudo isto são qualidades que não se 'aprende na escola', para usar estribilho de samba muito conhecido.” (Borges Pereira, idem: 159)
\end{abstract}

O autor qualifica tal ideário - que relaciona atributos "raciais" a aptidões artísticas - como uma construção estereotipada resultante de um longo processo histórico. Nesse processo, o talento do branco é definido como "trabalhado, fabricado, imposto", enquanto o do negro seria "o talento puro, autêntico, sem manipulações estranhas, talento que flui naturalmente de dons individuais" (Borges Pereira, idem: 145). Ao lado da valorização do talento musical natural ("no sangue"), está a constatação de que pretos e mulatos são "naturalmente incompatibilizados com outros tipos de trabalho" (idem: 148). Ouve de seus informantes, por exemplo: “O negro é 'burro', só é criador e versátil com a música... Vivendo de improviso, ele não dispõe de elementos para orientar a si mesmo, como poderá orientar os outros..." (idem: 152/3).

Essa digressão histórica e temática permite refletir sobre algumas das formas de pensar a música entre os sujeitos pesquisados e na sociedade brasileira atual. Ouvi de professores, coordenadores, pais e alunos do Guri que o brasileiro tem "música no sangue", que os meninos da Febem têm mais facilidade em aprender música porque têm "ginga", aprendida na vida da favela, "pulando muro, andando em viela”"144. Nesses casos, a noção racial é estendida para uma iden- 
tidade de grupo ou nacional: não é mais o "preto", mas “o pobre” - e, no limite, "o brasileiro" - que é dotado do talento "natural” (do sangue) para a música.

A associação entre a atividade musical e ascensão social é também parte do senso comum de alunos e pais que procuram o Projeto. A possibilidade de profissionalização - sugerida ou efetivamente planejada - é um dos atrativos para a permanência dos jovens no Guri. Mesmo que o Projeto não se descreva como profissionalizante e até declare que seu objetivo não é "formar músicos", essa perspectiva está presente entre boa parte dos jovens que eu conheci.

Não faltam modelos para inspirar essa perspectiva. A história narrada por Borges Pereira é um desses. Há também na indústria fonográfica inúmeras histórias de músicos que, nascidos em famílias pobres, ou distantes dos centros urbanos, viram estrelas "pop”: a música permite um destaque antes impensável. Há, por fim, uma tradição, cuja história demanda mais pesquisa, de interação social por meio do aprendizado musical: em igrejas, sobretudo evangélicas, espalhadas pela cidade, freqüentadas principalmente por famílias de baixa renda, são criadas escolinhas de instrumentos para formar o conjunto que tocará nos cultos. Aí tem início a formação de parte importante dos músicos que hoje compõem as orquestras jovens e profissionais ${ }^{145}$.

Em todos esses exemplos, a música é uma possibilidade (sonhada ou efetiva) de inserção social. Difere bastante, porém, do aprendizado descompromissado do aluno de classe média ou alta, que vê na música ora um hobby, ora parte de uma formação pessoal mais ampla.

Um pai de aluno do Guri, negro, muito presente na educação musical de seu filho, me disse certa vez que era bom ser músico para "ser respeitado". Exemplificou contando sua experiência em uma batida policial, que fora amenizada pelo fato do motorista, negro, ter a carteira da Ordem dos Músicos. A frase poderia ter sido proferida nos anos 1930, quando o negro começava a ser respeitado por ser músico, como vimos. Ouvida nos anos 2000, indica a manutenção do preconceito racial, sua assimilação pelo próprio negro, e a continuidade do pensamento que associa a atividade musical à possibilidade de inserção social. 


\section{Contrapontos}

Música nem sempre é algo "bom”. No fim de 2001, abandonei meu curso na Escola Municipal de Música - lamentando muito deixar meu professor de violoncelo - porque não conseguia mais assistir chorando às aulas de teoria. Deparar-se com uma incapacidade musical - talvez minha, talvez falta de paciência do professor de teoria - estava me fazendo mal. Eu não era a única. Na última fila, outras alunas que não conseguiam reproduzir os "ditados melódicos" com a rapidez exigida tentavam disfarçar as lágrimas. Em nenhum outro processo pedagógico passei por situação e sensações parecidas. Música, naquele contexto, estava sendo algo muito ruim.

Por outro lado, lidar com uma situação como essa implica um enorme aprendizado sentimental. Faz sentido a afirmação de Alessandra, a violinista do pólo Mazzaropi, que conta que, depois da música, "o que você quer, você batalha e consegue. Isso em relação a tudo".

Música nem sempre é "harmonia”, “calmante”, “terapia”. Pode ser até irritante - e as audições são as mais subjetivas possíveis. Música pode ser também protesto: implícito em metáforas nas canções sob a ditadura, explícito nos raps atuais, simbólico na recusa de se tocar com um maestro com o qual não se compartilha uma ideologia ${ }^{146}$.

As situações aqui observadas mostraram-se indescritíveis pela ótica "harmônica”. Tal como nas composições das vanguardas musicais do século xx, nesta etnografia o ruído fez-se muito presente. Na apropriação metafórica do termo musical para o plano social, outras características revelaram-se sugestivas: dissonância, polifonia e polirritmia descrevem com mais propriedade a dinâmica vivida por jovens e crianças habitantes das franjas da metrópole em seu contato com a música. 
O ethos associado às formas musicais muitas vezes converte-se em preconceito. A idéia de que música corre no sangue de nossa gente fixa atributos e permite o desenvolvimento do imaginário demonstrado por Borges Pereira: aos negros, o universo da sensibilidade e da força física (música e esportes), aos brancos, a lógica, o raciocínio, a organização.

Nos últimos anos, para se falar em jovens e periferia tornou-se quase obrigatório falar em rap. Muitas vezes fui questionada quanto à escolha da música de orquestra como objeto de estudo para se pensar a situação do jovem de baixa renda. Por que não rap, grupos de percussão, manifestações populares?

Nunca deixei de ver no Guri - sobretudo na forma como é apresentado - traços de um projeto civilizatório. Nas falas da coordenação, a música de orquestra aparece como uma cultura de elite que está sendo oferecida para jovens sem acesso à “cultura”. No entanto, no cotidiano dos pólos, percebi que a música de orquestra é, sim, uma das músicas dessa periferia, praticada nas igrejas ou em famílias de músicos, por exemplo. Tal fato é conhecido pelos músicos que integram ou conceberam o projeto. O maestro João Maurício Galindo, um dos responsáveis pelo método para ensino coletivo de cordas no Guri, se assustou quando descrevi como objetivo do projeto o ensino de música erudita: "nós não propusemos música erudita, nós propusemos fazer música em conjunto”. A orquestra é uma das possibilidades de se fazer música em grupo.

Asa, outro maestro do Guri, defende o direito à diversidade musical. A idéia seria estender o conhecimento musical para outras sonoridades, além do tradicional "violão e cavaquinho". O detalhe é que Asa e Galindo são músicos atuantes no cenário profissional em orquestras que tocam Música Popular Brasileira. Ambos percebem também que essa mesma мрв é cada vez menos conhecida das gerações mais novas, e vêem na sua atuação uma das formas de divulgação do repertório popular junto ao público e aos músicos jovens. 
Em vários momentos na tese destaquei a importância atribuída ao coletivo pelos proponentes de diversos projetos destinados à população jovem de baixa renda. Os discursos dos proponentes destacam a importância das práticas em grupo no estímulo à sociabilidade, à formação de laços, à criação de um sentimento de permanência e de pertencimento.

Uma questão colocada por um amigo, antropólogo e músico, me fez retornar a esse tema, com outra abordagem. Por que - pergunta ele - a ênfase no coletivo nas atividades para os pobres, enquanto é o desenvolvimento individual a meta dos cursos para os ricos?

De fato - e principalmente nos cursos pagos de música - a ênfase pedagógica é no desenvolvimento individual. As aulas de instrumento são, em geral, particulares (e não em grupo), o estudo é solitário, a relação professor-aluno é muito próxima e o professor acompanhará o desenvolvimento do aluno passo a passo. Minha própria educação musical - desde a infância - foi assim.

Sem dúvida - respondi ao meu amigo - o estudo individual estimula o aprendizado, pode desenvolver mais rapidamente a técnica do instrumento, e, no limite, forma um virtuose ${ }^{147}$. Mas a música em grupo - tão pouco praticada nas escolas de música pagas ${ }^{148}$ - é algo de outra ordem. Minha recente experiência na montagem da ópera com alunos do curso de música da usp tem me ensinado um pouco mais sobre essa prática, até então mais observada no cotidiano do Guri que efetivamente vivida. Ouvir-se no meio de uma orquestra é uma experiência única. Você percebe que faz parte de algo muito maior, que, no entanto, depende de você. Há uma responsabilidade imensa: tocar errado a sua parte pode comprometer o resultado final. Cada músico compromete-se com o outro, em vários sentidos. O prazer de ouvir um trecho afinado em que todos estão em sintonia é enorme. Arrepia. Todas essas palavras - "responsabilidade”, "pertencimento", "comprometimento", "prazer" - ganham outra dimensão quando efetivamente sentidas na prática musical. Às vezes esvaziadas - como nos discursos dos proponentes, que muitas vezes nunca fizeram, eles próprios, música - revelam-se prenhas de sentido quando contextualizadas na experiência. Meu amigo, em grupo se faz música, de um modo muito particular. 
No início da tese notei que meu objetivo não era fazer uma análise institucional. Os alunos, professores, coordenadores e parceiros do Projeto Guri foram meus grandes interlocutores nesta pesquisa, muito me ensinaram sobre música, sobre a infância e juventude, sobre dificuldades, sonhos e realizações. É dessa matéria que trata o trabalho.

Nas etnografias que apresentei nos diversos capítulos, estão expostos qualidades e problemas do fazer musical tal qual realizado no Guri, embora o foco não fosse avaliar o trabalho realizado, mas observar e interpretar seus significados.

Procurei, sobretudo, mostrar a especificidade da música como forma de intervenção - tal qual proposta no Guri e em outros projetos de cunho social. Num momento de avaliação do projeto desta pesquisa fui questionada sobre o porquê de escolher a música como foco, e não esportes, teatro, artesanato etc. Na questão, colocava-se também em dúvida se faria alguma diferença o tipo de atividade oferecida, dado o caráter social dos projetos.

Escolhi a música porque faço música. Meu fazer levou-me ao encontro dos meninos que também iniciavam seu aprendizado. Optei por uma abordagem subjetiva, sensível, em que minha própria experiência estivesse presente no processo de observação e interpretação. Faz toda a diferença ser a música a opção de atuação do projeto. Como faria ser o futebol, a pintura ou o teatro. Esse trabalho indica um caminho possível de análise. Quanto não aprenderíamos sobre a infância e juventude brasileiras, sobre as formas de intervenção social e sobre as diversas manifestações sensíveis ou lúdicas se cada uma delas - e sua relação - fosse analisada em sua particularidade? 
A música ensaia e antecipa aquelas transformações que estão se dando, que vão se dar, ou que deveriam se dar, na sociedade.

José Miguel Wisnik

O maestro Daniel Barenboim descreve uma situação observada durante um workshop musical, realizado em Weimar, Alemanha, em 1999, com jovens de várias nacionalidades, algumas envolvidas em conflitos:

"[um garoto sírio] se viu dividindo uma estante com um violoncelista israelense. Eles estavam tentando tocar a mesma nota, tocar com a mesma dinâmica, o mesmo movimento de arco, o mesmo som, a mesma expressão. Estavam tentando fazer alguma coisa juntos. Simples assim. [...] alguma coisa de que gostavam, alguma coisa que os apaixonava. Bom, tendo conseguido aquela nota, já não podiam se olhar da mesma forma, porque haviam partilhado uma experiência comum.” (Barenboim \& Said, 2003: 28)

Barenboim e Wisnik compõem no mesmo tom. Variações sobre o tema que pretendi apresentar nessa composição de palavras, imagens, pausas e sons. 


\section{ABERTURA}

1 Cf. Wisnik, 1999.

2 O projeto, que teve início em 1995, na Oficina Amácio Mazzaropi, com a participação de 180 crianças e adolescentes, conta em 2003 com cerca de 100 pólos, atendendo cerca de 25 mil crianças em todo o Estado. Ao todo são 45 orquestras mirins, 25 cameratas de violão, 42 corais, seis big bands e 22 conjuntos diversos. No capítulo 3 apresento a proposta pedagógica do Guri.

3 São oferecidos cursos de violino, viola, violoncelo, contrabaixo acústico, percussão, saxofone, flauta transversal, trompete, trombone, trompa, oboé, fagote e clarinete, além de canto coral e teoria musical. Há também aulas de instrumentos populares, como violão, guitarra, contrabaixo elétrico e flauta doce.

${ }^{4}$ Em 2003, a Fapesp aprovou o temático “Alteridade, expressões culturais do mundo sensível e construções da realidade. Velhas questões, novas inquietações”, no qual pretendo desenvolver trabalhos com vídeo a partir de questões surgidas neste doutorado.

5 Parte das observações sobre as oficinas aqui apresentadas foi desenvolvida em comunicação apresentada por Paula Miraglia e por mim na IV Reunião de Antropologia do Mercosul (RAM), realizada em Curitiba, em novembro de 2001. Paula apresenta as oficinas como contexto de produção de parte importante dos depoimentos dos jovens internos que analisa em sua dissertação, sobre o universo do jovem em conflito com a lei (Miraglia, 2001). Em "Imagens em construção: O uso do vídeo como forma de comunicação com o interno da Febem” (Hikiji \& Miraglia, 2003), apresentamos a experiência das oficinas de forma detalhada.

6 A partir de setembro, nossas idas à Febem e as aulas tornaram-se um problema. As rebeliões, que já vinham acontecendo desde o início do ano (1999 foi ano de algumas das maiores rebeliões da história da Febem), passaram a ser freqüentes e mais violentas, o que implicou um "fechamento" da instituição. Perdemos classes inteiras por conta das 
fugas e os que não haviam fugido, "por uma questão de segurança”, estavam proibidos pela direção de sair da unidade. Fomos aconselhadas a suspender nossas idas à Febem. A oficina foi interrompida.

${ }^{7}$ Essa duração foi bastante variada. Rebeliões, fugas, desistências e desinternações eram responsáveis por grande flutuação nos grupos, o que inclusive dificultava a finalização dos processos por nós imaginados.

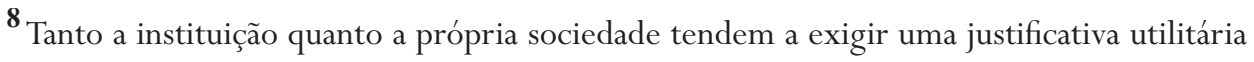
para as atividades oferecidas aos jovens internos. Eles “estão lá” para “aprender alguma coisa útil”, que seja uma alternativa "à vida do crime”, de preferência "uma profissão". Os cursos de música oferecidos pelo Projeto Guri na Febem enfrentavam o mesmo problema. Era recorrente a classificação da música como um privilégio não "merecido" ou como "ilusão" (cf. cap. 5).

9 A Febem-Tatuapé possui no interior do Quadrilátero (área que abriga todas as unidades) espaços externos às UEs que alguns dos jovens podem freqüentar. A maior parte das atividades profissionalizantes ou de lazer aconteciam nesses locais. Nossa oficina acontecia em sala anexa à biblioteca da Febem.

10 Escolhemos principalmente documentários curtos que tratassem de temas relativos à juventude e à periferia no Brasil. Exibimos, nas primeiras sessões, os seguintes vídeos: As pedras no meio do caminho (Bastos, Schuller \& Wainer, 1996), Meninos eu vi? (Salles [coord.], 1992) e Funk Rio (Goldemberg, 1994). Os dois primeiros são filmes que abordam o universo dos meninos e meninas de rua, sendo que As pedras no meio do caminho é resultado de uma oficina realizada pelos autores com jovens que moravam na praça da Sé, em São Paulo. Já Funk Rio trata da sociabilidade entre jovens cariocas a partir da cultura do Funk.

11 Cabe lembrar que esse programa deu uma cobertura peculiar às rebeliões que aconteceram nos anos de 1999 e 2000. Sempre que apresentava uma notícia sobre a Febem, o apresentador começa a narração chamando os internos de "esses meninos" e rapidamente passava a chamá-los de "marginais", "bandidos" e até "animais".

12 Apesar da riqueza etnográfica encontrada no pólo Febem, alguns fatores me levaram a ampliar a observação do cotidiano do projeto para outros pólos: a interrupção das atividades do projeto na Febem em maio de 2000 e as possibilidades colocadas pela 
dimensão comparativa, dada a existência do mesmo tipo de proposta de ensino musical, em situações que envolvem grupo etário semelhante, porém sem a questão da restrição da liberdade. Além dos pólos Febem e Mazzaropi, fiz pesquisa no pólo POF/Morumbi, que fica entre as favelas de Paraisópolis e Porto Seguro, no Morumbi. Conheci jovens de outros pólos nas apresentações conjuntas e em ensaios da Orquestra Paulista Juvenil do Projeto Guri.

13 Além de "Prelúdio", integra a tese o vídeo "Microfone, senhora", que discuto a seguir.

14 O nome é fictício, em respeito ao ECA.

15 Havia, dentre os internos que participaram da gravação dos CDs, meninos de 13 a 15 anos, da Unidade Educacional 7, que era, no Quadrilátero do Tatuapé, destinada aos jovens mais novos, a maioria internada por envolvimento com drogas, sobretudo crack. Havia também internos mais velhos: o jovem com menos de 18 anos que comete algum ato infracional pode ser internado na Febem por até três anos, o que resulta no fato de haver na instituição jovens de até 21 anos.

16 Em uma das oficinas, fomos à UE7 para "registrar" uma festa junina. Na festa, os participantes da oficina filmaram e entrevistaram funcionários e internos.

17 João, o protagonista do vídeo, afirmou várias vezes que queria se profissionalizar como músico. Outros jovens também apostavam nesta possibilidade. Nas entrevistas que os jovens faziam com coordenadores a questão do "sucesso" estava sempre presente nas respostas. À parte a grande dificuldade de realização desses “sonhos”, é importante notar que a parceria da Febem com o grupo Jigaboo (Projeto Realidade) teve continuidade por algum tempo: jovens internos e desinternados realizaram várias apresentações com o grupo em São Paulo e Minas. Os membros do grupo ainda hoje têm contato com alguns desses jovens. Dois jovens chegaram a negociar com uma gravadora a realização de um CD. Não sabemos se João ainda faz música, mas, aparentemente, ele não voltou a se envolver em práticas ilegais e mudou com sua mãe para o interior de São Paulo.

18 Como não estava trabalhando com jovens da oficina de vídeo, não foi meu objetivo deixálos filmar. Era preciso garantir uma qualidade mínima de imagem que não seria obtida por pessoas que nunca tinham segurado uma câmera.

${ }^{19}$ A desigualdade social e de status (livres x presos) marcava de forma radical nossa relação: várias vezes, os jovens me lembravam que eu era "playboy”, não “de periferia” (cf. cap. 
4). Também a relação dos jovens com a criminalidade e com a violência colaborava para a dificuldade em me aproximar: não posso dizer que me sentia totalmente à vontade (e segura) em estar na Febem (principalmente na época das constantes rebeliões).

${ }^{20}$ Sobre Jean Rouch, ver Colleyn (1995), Sztutman (1997), Rouch (1995 [1974]), entre outros.

${ }^{21}$ Aos jovens da Febem, que participam do vídeo, não pude exibi-lo, uma vez que eles não se encontram mais internados e seu paradeiro é, em geral, desconhecido. Um projeto que tenho é procurar alguns desses jovens para dar continuidade ao trabalho.

22 O vídeo Microfone, senhora foi selecionado para $9^{a}$. Mostra Internacional do Filme Etnográfico, realizada no Rio de Janeiro, entre 9 e 17 de dezembro de 2003. Também foi exibido no mês de novembro de 2003 no programa "Cinema \& Antropologia”, no Canal Universitário (UTV).

${ }^{23}$ Luiz Eduardo Soares (2001) discute a invisibilidade característica de jovens como os meninos de rua ou internos na Febem (cf. cap. 2).

\section{CAPÍtULO I}

${ }^{24}$ Aqui, falarei ora em etnomusicologia, ora em antropologia sonora ou antropologia musical. Interessam-me os estudos desenvolvidos por antropólogos a respeito dos encontros entre manifestações musicais e relações sociais, de forma ampla. Na história da etnomusicologia, a denominação da própria disciplina sempre foi alvo de debates, que não serão considerados neste espaço. Independentemente da forma como desejaram denominar suas abordagens, os autores aqui considerados tinham em comum um legítimo interesse nas manifestações musicais dos grupos que estudavam, e são as etnografias resultantes deste interesse que despertaram a minha curiosidade antropológica.

${ }^{25}$ Citado em STOLLER, Paul. The taste of ethnographic things: the senses in Anthropology. Philadelphia, University of Pennsylvania Press, 1989. Apud HOWES, 1991: 9.

${ }^{26}$ Há exceções, que, no entanto, não invalidam a afirmação da superioridade atribuída à visão em nossa sociedade: em francês, "entendre" significa entender e escutar. Em inglês, o surdo é chamado "dumb and deaf", o que associa a ausência da audição a uma incapacidade cognitiva. No Brasil, "você é surdo!" corresponde a "você não entende/ 
percebe”; há também o “escuta aqui!”, que geralmente precede uma discussão, bronca. Curioso notar que em inglês e em português, quando se aproxima audição e cognição, há, em geral, um tom negativo nas expressões.

27 Modos são determinados estoques de intervalos musicais que podem ser combinados para formar melodias. José Miguel Wisnik (1999: 75; itálicos do autor) lembra que nas sociedades pré-modernas, “um modo não é apenas um conjunto de notas mas uma estrutura de recorrência sonora ritualizada por um uso. [...] o modo pode estar relacionado, por exemplo, com um deus, uma estação do ano, uma cor, um animal, um astro”. Para os gregos, os modos relacionavam-se a diferentes estados de espírito e sugeriam comportamentos diversos, que variavam da seriedade e civilidade à embriaguez e à festa.

28

Evitarei usar o termo arte, ou manifestações artísticas, uma vez que a música não é, em várias sociedades, vista como tal; ou seja, cantar ou tocar instrumentos não é, em determinados grupos e situações, parte de uma experiência estética isolada dos demais campos da vida cotidiana, como veremos a seguir. Diz Seeger: "Nossa suposição de que a música é uma 'arte', uma atividade antes de tudo estética e além disso incidental, fez com que não entendêssemos a música das terras baixas da América do Sul. Para essas sociedades, a música é parte fundamental da vida social, não somente uma de suas opções” (1980: 104). Cabe notar que autores como Alfred Gell (1998) procuram pensar a arte de diversos povos - inclusive a arte contemporânea ocidental - sem isolá-la na esfera “estética”, mas sim pensando como são mobilizados princípios estéticos no curso da interação social.

${ }^{29}$ Nos capítulos três e quatro desenvolvo reflexões a partir desta experiência.

30 Cabe notar que esse movimento de crítica às etnografias clássicas foi impulsionado a partir de idéias advindas da crítica literária. Antes da etnografia, a literatura experimentou - e experimenta - outras possibilidades narrativas, inspirada pelo universo onírico, pelas diversas formas de manifestação da memória, pelo cinema.

31 Robert Stam (1992) vê em Brecht o exemplo-chave da arte reflexiva. O dramaturgo utiliza como recursos de interrupção da narrativa: canções, “quadros" congelados, a fala do ator diretamente para a platéia. O resultado é a substituição do envolvimento empático por uma reflexão distanciada.

32 No piano, os doze semitons correspondem a todas as teclas (brancas e pretas) que com- 
põem uma oitava (sem a repetição da nota fundamental oitavada, ex: de dó a si). Se partirmos de um dó, teremos este, o dó sustenido, o ré, o ré sustenido, o mi, o fá, o fá sustenido, o sol, o sol sustenido, o lá, o lá sustenido e o si.

${ }^{33}$ Todas as citações de Seeger são traduções minhas do original em inglês.

34 No ensaio "Art as a cultural system”, ao propor uma abordagem semiótica da arte, Geertz (1983) une sob o mesmo rótulo (“arte”) várias manifestações sensíveis, como percussão, escultura, pintura (sobre tela, sobre o corpo etc.), danças e cantos de sociedades simples ou complexas. Tal postura difere daquela de autores que evitam o termo "arte" por perceber que a manifestação sensível em questão não é vista como tal nas sociedades estudadas.

35 José Guilherme C. Magnani lembra que a própria discussão sobre lazer e tempo livre em um país como o Brasil, marcado pela desigualdade social, costuma ser mal-vista e apresenta sua contra-argumentação: "Poderia parecer fora de propósito discutir tempo livre e lazer quando contingentes expressivos da população, em estado de miséria absoluta, não têm acesso sequer ao trabalho, numa situação até mais perversa que aquela descrita quando dos primórdios da revolução industrial. Mas exatamente por se tratar de uma situação de contraste é que, além dos dois lados extremos do quadro, existe uma significativa região intermediária. Se, para alguns, as reflexões na linha de D’Épinay já fazem sentido, e para outros a questão do lazer é um luxo, existem muitos outros, também, para os quais a prática do lazer ainda é um direito a ser conquistado, consolidado.” (Magnani, 2003: 2).

36 João Baptista Borges Pereira (2001 [1967]) analisou o processo de inclusão do negro no sistema radiofônico a partir do final dos anos 1930, mostrando como a música - principalmente o samba - possibilitou alguma mobilidade social para grupos antes discriminados. Retomo tal reflexão nas Considerações Finais desta tese.

${ }^{37}$ No vídeo Prelúdio, parte integrante desta tese, esta idéia é desenvolvida de forma audiovisual. A discussão sobre aprendizado musical é realizada no capítulo três e sobre a relação entre música e identidade, no capítulo quatro.

38 A principal sala de concertos de São Paulo, considerada como uma das melhores do mundo, foi inaugurada em 1999, no interior da antiga Estação Júlio Prestes. Conta com 
1.509 lugares e é a sede da Orquestra Sinfônica do Estado de São Paulo (Osesp).

39 Grupos de alunos do Projeto Guri participaram de vários eventos com este formato. Este, especificamente, ocorreu no segundo semestre de 2003, e foi amplamente divulgado na mídia de São Paulo.

\section{CAPÍTULO II}

40 No capítulo 1, apontei o questionamento efetuado por etnólogos da separação efetuada no Ocidente moderno entre a arte e os demais domínios da vida social como algo que inviabiliza a compreensão das sociedades indígenas da América do Sul. Ver Overing (1991) e Seeger (1987).

41 A catequese jesuítica, empreendida no século 16, pretendia "reorientar a cultura nativa em direção ao cristianismo", transmitindo os valores da moral cristã, do trabalho como virtude e da disciplina. A catequese tinha nos “curumins” destinatários primordiais, que agiam "como intérpretes e agentes dos mecanismos de controle sociocultural dos catequistas". A música e o teatro eram importantes instrumentos dos jesuítas (Azevedo, 1976: 372). De ordem um pouco diversa, a catequese salesiana, desenvolvida com os índios Bororo, do Brasil Central, a partir do início do século XX, tinha como modelo de atuação a vida de Dom Bosco e sua dedicação aos meninos de rua. A caridade, expressa na tentativa de formação profissional, procurava oferecer para as crianças de Turim (Itália), com quem Dom Bosco trabalhava, "uma nova possibilidade de vida” (Caiuby Novaes, 1993: 174/5). Tal informação, sobre a inspiração para a catequese salesiana com os índios do Brasil Central, aproxima ainda mais o ideário de Villa Lobos do missionário. E permite vislumbrar aproximações entre os projetos atuais de intervenção social com crianças e jovens de baixa renda e os ideais de caridade das missões cristãs.

42 Os itálicos são meus.

43 A Casa do Zezinho é um projeto de cooperativa educacional e assistencial, no Parque Maria Helena, em São Paulo. Atende a população de 05 a 18 anos do Parque Santo Antônio, Capão Redondo, Jardim Ângela, entre outros. Oferece atividades em arte-educação - ênfase em artes plásticas - no período em que as crianças não estão na escola. Os coordenadores do projeto me concederam entrevistas e apresentaram sua proposta 
de trabalho.

44 As definições são de coordenadoras do Projeto entrevistadas por mim entre 1998 e 2002.

45 O capítulo 3 tem como foco a prática musical no cotidiano dos pólos.

46 "Foram priorizados sentidos, ou seja, que significados seriam transmitidos para e pelos jovens e que conotações seriam dadas a uma série de termos que - à custa de tanto se repetir - se tornam esvaziados ou ambíguos” (Castro, 2001: 482).

${ }^{47}$ Em enquête sobre a importância do trabalho no imaginário do jovem de baixa renda (in Castro, 2001: 47), é atribuído o mesmo lugar à rua e ao tempo ocioso: “Os jovens, como seus pais, enfatizam a importância do trabalho como forma de ocupação do tempo, da mente, o que os impediria de estar pensando em cometer qualquer infração. Assim, afirmam que se houvesse emprego, muitos jovens não estariam envolvidos em atividades ilícitas: [...] Que nem diz o outro: 'cabeça parada, oficina do diabo'." Uma discussão mais aprofundada sobre as temporalidades das crianças e jovens de São Paulo será efetuada no capítulo 5 .

48 Cap. 2; Art. 15 - A criança e o adolescente têm direito à liberdade, ao respeito e à dignidade como pessoas humanas em processo de desenvolvimento e como sujeitos de direitos civis, humanos e sociais garantidos na Constituição e nas leis.

49 Não encontrei uma definição única para “situação de risco". Tal expressão não consta do ECA, mas quase todos os proponentes de projetos de intervenção social (governamentais ou não governamentais) utilizam-na, sempre aproximando o risco a ser combatido de sua área de atuação.

50 Além de coordenadores e professores do Projeto Guri, entrevistei os responsáveis pela Cooperativa Educacional e Assistencial Casa do Zezinho e uma das coordenadoras do projeto Sou da Paz, ambos de São Paulo. Além disso, venho acompanhando material divulgado por projetos na Internet ou na mídia impressa.

51 Em Castro (op.cit.), entende-se por “jovens em situação de risco” aqueles que pelo ambiente em que vivem e freqüentam têm mais probabilidades de serem vítimas ou autores de violências. Esta associação do risco à violência é comum no discurso de vários projetos.

52 Miraglia (2002) faz um levantamento de estudos e dados acerca do crescimento da criminalidade entre jovens no Brasil. Cita Adorno (1999), Soares (1996) e Zaluar (1998) 
como importantes referências.

53 Sempre que apresentada, a taxa corresponde ao número de homicídios por 100 mil habitantes da região. Os dados são de Miraglia (2002), que usa como fontes o SIM/ DATASUS, o IBGE e o Mapa da Violência III - Unesco.

54 Fonte: Fundação Sistema Estadual de Análise de Dados - SEADE. No mesmo ano a taxa para cidade de São Paulo era de 121,33 (Miraglia, 2002).

55 Miraglia (2002) lembra que o IVJ foi uma “encomenda” da Secretaria de Estado da Cultura, com o objetivo de justificar a necessidade de financiamento do BID (Banco Interamericano de Desenvolvimento) para a implantação de programas na periferia da capital.

${ }^{56}$ Tal objetivo é declarado nas apresentações dos projetos na mídia, em publicações especializadas (impressas e eletrônicas) e em depoimentos a pesquisadores.

57 Em virtude de ser promovido pela Secretaria de Cultura do Estado de São Paulo, o Projeto Guri realiza suas apresentações em algumas das principais salas de concerto do Estado, como a Sala São Paulo, o Memorial da América Latina, e em eventos musicais já tradicionais no país, como o Festival de Inverno de Campos de Jordão. A possibilidade de ampliação de horizontes dada pelo contato com estes espaços é analisada no capítulo "Etnografia da Performance".

58 Miraglia (2001) lembra que a partir do ECA usa-se denominar como "ato infracional" o motivo que levou o jovem à internação. No entanto, a autora percebe que tanto os jovens como a mídia se utilizam da categoria “crime”. Portanto, opta em utilizar as duas denominações - conforme o universo em destaque - uma vez que falar em ato infracional seria usar uma categoria estranha aos próprios pesquisados, com exceção dos interlocutores do próprio universo judiciário.

59 A postura, reforçada pela regra institucional, remete, entretanto, à observação de um professor da Associação Curumins, de Fortaleza, Ceará, que atende jovens de baixa renda, não internos: "Tinha menino, quando chegou aqui, que morava embaixo do boné" (in Castro, 2001: 172).

60 No capítulo "Etnografia da performance" discuto com mais detalhe a relação entre a performance musical - em apresentações para públicos diversos com jovens de diferentes pólos - e os processos de construção de identidades, auto-imagens e de ampliação de horizontes. 


\section{CAPÍTULO III}

61 Essa orquestra, composta pelos alunos mais avançados e mais velhos do Projeto Guri, foi extinta em 2003. Segundo João Maurício Galindo, um dos seus regentes, um dos motivos da extinção teria sido a dificuldade de trazer os jovens de pólos do litoral e do interior para os dois ensaios semanais que aconteciam no centro de São Paulo.

62 As frases entre parênteses foram retiradas de material de divulgação institucional. O pólo Febem teve suas atividades encerradas em maio de 2000 e retomadas em 2002. Até 2000, era um dos pólos de maior destaque na mídia, por sua peculiaridade. Cabe notar que a presença de jovens desinternados no pólo Febem do projeto Guri era bastante rara. Não havia tampouco uma política de estímulo à participação do adolescente desinternado em outro pólo do projeto.

${ }^{63}$ Em alguns casos, é permitida a permanência no pólo ou na orquestra de jovens com mais de 18 anos.

${ }^{64}$ Os principais instrumentos ensinados no Guri são violino, viola, violoncelo, contrabaixo acústico, percussão, saxofone, flauta transversal, trompete, trombone, trompa, oboé, fagote e clarinete. Há também aulas de instrumentos “populares”, como violão, guitarra, contrabaixo elétrico e flauta doce. Em alguns pólos, são estes os que predominam, como no POF, pólo pesquisado no primeiro semestre de 2002, no qual só havia aulas de violão e canto.

65 Nem sempre a escolha do instrumento é feita pelo aluno. Muitas vezes, o instrumento que o aluno gostaria de tocar já está com a classe cheia e um outro instrumento lhe é indicado.

66 Os ingressos para os concertos da Sociedade de Cultura Artística, em São Paulo, chegam a custar mais de um salário mínimo ( $\$$ 240,00, em 2003) a unidade!

${ }^{67}$ A Escola Municipal de Música é um dos locais de ensino público e gratuito de instrumentos e teoria musical. O ingresso na escola se dá por meio de rigorosa seleção, com testes de aptidão para o instrumento e provas de teoria. Juntamente com a Universidade Livre de Música (ULM), é um dos poucos locais em São Paulo de formação de músicos, com professores que fazem parte dos principais conjuntos musicais do Estado.

68 A relação entre casa e rua e a temporalidade dos jovens será discutida no capítulo 5. 
69 Há muita controvérsia sobre a relação entre idade de início da prática e capacidade ou talento musical. Alguns músicos lembram que em um país de pouca tradição em música erudita como o Brasil não é possível esperar que instrumentistas sejam treinados desde a primeira infância e que seria contraproducente ignorar talentos que se revelam já na adolescência, quando não na vida adulta. O exemplo do pianista Arnaldo Cohen, músico brasileiro internacionalmente reconhecido, é sempre lembrado: tendo iniciado sua carreira pianística após os 20 anos, tornou-se um dos mais respeitados pianistas do mundo. Alberto Jaffé, cujo método será apresentado a seguir, faz questão de lembrar que a idade nunca foi empecilho para a profissionalização de seus estudantes, muitos dos quais começaram a estudar na adolescência.

70 No Método Jaffé, um dos pioneiros do ensino coletivo de cordas no Brasil, tal "toque" que “ajuda a transmitir ao aluno as sensações cinestésicas relativas ao ato de tocar” é chamado “assistência manual”. Outra característica do método - analisado mais detidamente a seguir - é a demonstração pelo professor da execução do instrumento, "estabelecendo, deste modo, o padrão auditivo e visual necessários ao aprendizado do aluno” (Oliveira, 1998: 17).

71 Michael Taussig (1993) questiona o privilégio dado à visão em nossa cultura, lembrando a análise de Benjamin sobre o conhecimento tátil. Esse autor exemplifica com a arquitetura o conhecimento fisionômico, construído pelo hábito: o conhecimento dos aposentos do apartamento onde moramos, por exemplo, não se daria somente pela visão, mas seria principalmente tátil.

72 Segundo Galindo, o método baseia-se em experiências dele com ensino coletivo de instrumentos de cordas. Dentre estas, aponta o Projeto Guri, onde desenvolveu atividades como maestro.

73 A noção de peso é fundamental na prática do instrumento de arco. Oliveira, em seu método para ensino coletivo de instrumentos de arco, diz: "O equilíbrio da postura favorece o relaxamento na hora de tocar. Sem equilíbrio, haverá, provavelmente, pontos de tensão excessiva em determinados músculos que suportam mais peso do que outros. Se o peso do corpo estiver distribuído igualmente entre todos os músculos, a postura não sofrerá tensões excessivas, favorecendo a realização adequada dos movimentos" (1998: 84). 
74 Taussig (1993: XIII) define a faculdade mimética como "the nature that culture uses to create second nature, the faculty to copy, imitate, make models, explore difference, yield into and become Other”. A inspiração do autor é benjaminiana e tem como objetivo, entre outros, criticar a ênfase na visualidade como meio de conhecimento, ressaltando a possibilidade de percepção com o corpo e não apenas com o "olho da mente”.

75 O Seitai-Ho, tal qual difundido por Toshi, é uma prática de vida inteira. Nos espaços em que Toshi transmite o Seitai-Ho, os alunos têm ao menos uma aula de cerca de 3 horas por semana.

76 Destinado a crianças e jovens de 10 a 18 anos, o programa trabalha com a formação de instrumentistas, em especial de instrumentos de cordas para orquestra - violino, viola, violoncelo, contrabaixo. O curso, com dois anos de duração, também se propõe a desenvolver o talento, a criatividade e a sensibilidade dos alunos. Utilizando-se de um método de ensino coletivo, permite que, após três meses de aula, os alunos sejam capazes de fazer suas primeiras apresentações. Atualmente, cerca de 540 alunos estão matriculados no curso (in http://www.institutopaodeacucar.org.br/acorde.asp).

${ }^{77}$ Violino, viola, violoncelo e contrabaixo.

78 A reflexão sobre a situação da internação é realizada no capítulo 5.

79 Os números são referências ao Código Penal.

80 Elza, funcionária da Febem na área de Projetos Especiais, explicou que não é praxe os professores ou funcionários terem ou conhecerem a ficha do menino. Com isso, espera-se garantir ao jovem um atendimento indiferente ao seu histórico em conflito com a lei. Algo como: "aqui, você é aluno, não importa o que você tenha feito/sido: ladrão, estuprador, assassino”. Paula Miraglia (2001) entende a recomendação de não se falar sobre a infração cometida como uma tentativa de evitar que o jovem se apegue à sua história pregressa, que seja constrangido, que reviva uma experiência traumática por meio da narrativa do fato em si, ou que fique conhecido (e até famoso) dentro da Febem pelo crime que cometeu. Já, falar do tempo de internação seria uma reflexão acerca do período passado na instituição, o que aprendeu, o que fez de errado, o que faria de diferente.

81 Paula Miraglia e eu desenvolvemos durante alguns meses de 1999 oficinas de vídeo com jovens de várias unidades da Febem (cf. Abertura). 
82 Os sentidos da associação da música ao universo do trabalho ou do lazer, conforme a circunstância, serão analisados mais detidamente no capítulo cinco.

83 Essa denominação é minha. Já “casa” era o termo usado por internos e funcionários para definir o local no qual aconteciam as aulas do Guri.

841999 foi ano de algumas das maiores e mais violentas rebeliões da história da Febem. Em agosto deste ano, teve início uma crise na instituição que afetaria as diversas unidades da Febem em São Paulo. No dia 3 de setembro de 1999, 64 internos fugiram da Febem Tatuapé. Onze dias depois, mais 37 adolescentes conseguiram fugir. Em 23 de outubro, tem início uma rebelião que iria mudar a história da instituição. Numa crise que durou três dias, mais de 1.000 dos quase 1.300 internos se rebelaram, tomando conta da unidade Imigrantes, botando fogo nos prédios, mantendo monitores e internos como reféns ou espancando-os na frente dos pais que aguardavam do lado de fora e, finalmente, matando quatro internos, sendo que um deles teve sua cabeça decepada enquanto os outros dois tiveram seus corpos carbonizados. As cenas não poderiam ser mais aterrorizantes. Em novembro de 1999, a unidade Imigrantes foi demolida. Um número grande de meninos foi transferido para instituições do sistema carcerário (cf. Miraglia, 2001). Segundo Miraglia (idem), nessa ocasião, incêndios provocados pelos jovens em diversas unidades resultaram na destruição parcial ou total de 14 das 16 unidades do Tatuapé, na fuga de quase metade da população de internos, em jovens e monitores feridos e no pedido de demissão da então secretária Alda Marco Antonio (da Secretaria Estadual do Menor).

86 “Projeto Guri leva música a crianças carentes”, matéria de Ricardo de Souza publicada n’ O Estado de S.Paulo, em 5/6/00.

${ }^{87}$ Tais aspectos serão discutidos também no capítulo5.

$\mathbf{8 8}$ As expressões não são liberdade poética dos jovens. O tratamento ao menor que comete infração e é internado na Febem continua a contrariar as claras disposições do Estatuto da Criança e do Adolescente (ECA). Durante a pesquisa - e o noticiário recente indica que a situação em algumas unidades é ainda pior atualmente - em várias unidades da Febem Tatuapé (principalmente, nas que abrigam jovens que cometeram infrações classificadas como graves - homicídio, estupro, tráfico, por exemplo), os adolescentes dormiam em quartos que eram trancados por fora, tinham acesso controlado às áreas 
comuns (pátio, banheiro) e, em situações especiais, recebiam como castigo o isolamento e a proibição de sair do quarto durante vários dias. Tais fatos eram comentados, no cotidiano da Febem, tanto pelos próprios menores, quanto por funcionários. O noticiário sobre as rebeliões, em 1999, e a cobertura posterior da mídia sobre a situação da Febem mostram como a situação não era desconhecida nos meios judiciários ou pelos governadores.

${ }^{89}$ Tal critério não era sugerido pela coordenação do Projeto Guri, nem pela coordenação de Projetos Especiais da Febem, mas, de acordo com observações durante a pesquisa, era o critério de vários diretores de UEs. Em virtude disso, eram quase sempre os mesmos internos que participavam das atividades extra-escolares, cf. desenvolvo no cap. 5.

90 Manchete do jornal Folha de S. Paulo de 6/6/97. Outros exemplos: "um dos melhores exemplos da força do projeto Guri é o pólo da Febem. Segundo o secretário da cultura, desde o início das atividades, em 1996, a unidade que abriga o projeto teve as fugas reduzidas em 42\%. Na última rebelião o único local preservado pelos internos foi onde os instrumentos musicais estão guardados” (O Estado de S. Paulo, 5/6/00; itálicos meus); ou "Desde a implantação dessas e de outras ações (prática de esportes, programas de teatro, instauração de bibliotecas, etc), o número de fugas dos jovens diminuiu $41 \%$ de janeiro a abril deste ano, em comparação ao mesmo período de 96. Eles recuperam a auto-estima”, fala Vanda [Teixeira, diretora-geral da Febem]” (Folha da Tarde, 10/06/ 1997).

91 Aqui, retomo a proposta de Overing (1991) de aproximar a reflexão da estética das demais esferas sociais, exposta no capítulo 1.

$92 \mathrm{O}$ aspecto da performance, no qual a apresentação tem papel central, é analisado no capítulo 4 .

\section{CAPÍTULO IV}

93 Então secretário de Cultura do Estado de S.Paulo e um dos idealizadores do Projeto Guri.

94 Fala aproximada de Marcos Mendonça na apresentação da Orquestra do Pólo Mazzaropi na abertura do concerto de 28.9.98 no Cultura Artística. 
95 Foi Valdir quem se apresentou como tal em nosso primeiro encontro ("sou o concertino, o segundo violino da orquestra; ela é a spalla”).

96 Clifford Geertz descreve que, nos primeiros dias de sua estada em uma aldeia balinesa, os nativos tratavam a ele e a sua esposa como “criaturas invisíveis”, “não-pessoas”: ninguém os cumprimentava ou ameaçava. O autor conta que esta situação inverte-se no dia em que ele e a esposa fogem da polícia local, junto com os demais balineses que assistiam a uma briga de galos, "Não só deixáramos de ser invisíveis, mas éramos agora o centro de todas as atenções...” (1989: 282).

97 Aqui e nos demais lugares nos quais cito a “coordenação” do Projeto Guri tenho como referência entrevistas realizadas com Silvana Cardoso e Nurimar Valsecchi, coordenadoras técnicas do projeto, e com Ângela Maria Visconti, supervisora técnica do Guri.

98 Sylvia Caiuby Novaes (1993: 24-8) define auto-imagem como "um conceito relacional [que] se constitui, historicamente, a partir de relações concretas muito específicas que uma sociedade ou grupo social estabelece com os outros”. Portanto, auto-imagem não implica características fixas, mas "extremamente dinâmicas e multifacetadas, que se transformam, dependendo de quem é o outro que se toma como referência para a constituição da imagem de si”. Nesse sentido, auto-imagem é fundamentalmente diferente de identidade, esse sim "um conceito que fixa atributos, exatamente por operar a partir de sinais culturais diacríticos”. A identidade é evocada para a "criação de um nós coletivo", existente enquanto igualdade apenas no plano do discurso, sendo "um recurso indispensável no nosso sistema de representações”.

99 Melanie Farkas, presidente da Sociedade Amigos do Projeto Guri, durante apresentação do concerto de inauguração da sede da entidade, na Sala São Paulo, no segundo semestre de 2000. As apresentações que introduzem as orquestras do Guri não diferem substancialmente desta fala de Melanie.

100 A existência do pólo Febem, por sua especificidade, é sempre lembrada nas apresentações dos concertos. Isso ocorre mesmo em concertos em que não há nenhum jovem da Febem se apresentando. Com isso, muitas vezes se dá uma confusão na qual os jovens de outros pólos são identificados como internos, o que geralmente causa certo mal-estar entre os alunos.

101 Como lembra John Dawsey (1998), a educação sentimental é um dos efeitos didáticos 
do teatro da vida social balinesa ressaltados por Clifford Geertz.

102 A referência é a analogia de Lévi-Strauss (1991: 24-5) entre música e mito, apresentada na Abertura.

103 Daí a importância de se pensar a performance como uma "seqüência total”, tal como proposto por Richard Schechner (1985). Para o autor, a performance deve ser pensada como uma seqüência de sete partes: treinamento, workshops, ensaios, aquecimentos, performance, esfriamento, conseqüências.

$104 \mathrm{Na}$ ocasião da pesquisa, a Febem tentava dividir os internos nas unidades por idade e grau de infração. Havia unidades com jovens de até 15 anos - e a idade em geral coincidia com um tipo de infração considerada menos grave. Os “maiores” são também os mais velhos (de até 21 anos), ora autores de infrações consideradas graves, ora médias.

105 Na Febem, não são mais usados uniformes. Os internos vestem-se com roupas trazidas por parentes ou fornecidas pela instituição.

106 A referência aqui é o conceito de Walter Benjamin, que Dawsey (1998: 64) aproxima da antropologia, definindo-o como a busca por uma “'descrição tensa', carregada de tensões, capaz de produzir nos próprios leitores um fechar e abrir de olhos, uma espécie de assombro diante de um cotidiano agora estranhado, um despertar”.

107 Durante a pesquisa, mais de uma vez fui provocada por internos: "a senhora é boyzinha, né?”. Se perguntados por quê, lembravam o fato de eu possuir um carro (“que marca? É carro de boyzinho!”), perguntavam em que bairro eu morava. A posse de bens ou roupas por eles desejados, bem como a localização da moradia (periferia x centro), são fatores determinantes para a inclusão do interlocutor na categoria em questão.

108 Pedro Guasco mostra que no discurso do jovem da periferia - e ele analisa os rappers paulistas - o playboy é a principal categoria de oposição: “descreve um tipo social definido não só pela sua origem e sua condição econômica, mas também por um determinado padrão de comportamento que se opõe a todo um código de normas de conduta e valores que, embora não possa ser generalizado ou pensado em consenso, é bastante comum entre as camadas populares" (Guasco, 2001: 88). O playboy compartilha com o rapper a faixa etária, mas, "como rival, ele é rico e geralmente branco". Guasco nota que ainda que o playboy não seja branco, nem rico, "o seu comportamento é pautado pelos costumes que acusam a opulência e a futilidade”, exemplificado no consumismo e 
nas referências às roupas, aos carros e na freqüência aos shopping centers. Em resumo, a idéia de um oposto estrutural é confirmada, independentemente das reais condições sociais daquele que é definido como playboy.

\section{CAPÍTULO V}

109 A teoria musical ocidental relaciona "intensidade", "altura" e "timbre” como suas outras propriedades.

110 José Miguel Wisnik também afirma a relação dupla da música com o tempo, ressaltando, porém, a relação consciente/inconsciente: "Desiguais e pulsantes, os sons nos remetem no seu vai-e-vem ao tempo sucessivo e linear mas também a um outro tempo ausente, virtual, espiral, circular ou informe, e em todo caso não cronológico, que sugere um contraponto entre o tempo da consciência e o não-tempo do inconsciente.” (Wisnik, 1999: 28).

111 Concerto para todos os instrumentos da orquestra, que resulta em grande sonoridade e, em certo sentido, “peso”.

112 Pensa-se aqui na diminuição das horas trabalhadas por dia, no processo que vai da Revolução Industrial - quando até as crianças não trabalhavam menos que 15 horas por dia - até os anos 1920 quando começam a surgir, em alguns países, as jornadas de oito horas e a semana de cinco dias (Waichman, 2001: 33/4).

113 O próprio autor não resistiu à utilização dos modelos de ritos de passagem e dramas sociais para pensar situações em "todos os níveis de organização social, do estado à família”. Como pontua, criticamente, Clifford Geertz: "migrações, divórcios, ou assassinatos em catedrais" recebem tratamento homogêneo a partir da analogia do drama (Geertz, 1983: 28-30).

114 O processo de gravação do rap com os jovens internos é apresentado no vídeo Microfone, senhora, que integra a tese, conforme discuto na Apresentação.

115 POF e São Remo são pólos instalados em favelas, com atividades destinadas às comunidades locais. O Mazzaropi, por sua tradição (é o mais antigo) e localização (próximo à estação Belém do Metrô), recebe alunos da região central de São Paulo, mas também das zonas leste, oeste, norte e até de cidades vizinhas, como Guarulhos. 
116 Boa parte dos grupos de rappers se organiza em "posses": "A posse integra número variado de grupos e busca ações mais estruturadas”, tem caráter político e preocupação com aspectos organizativos (Sposito, 1993: 170).

117 A música é uma das "forma lúdicas de arte" analisadas por Huizinga em Homo Ludens (2000).

118 Na etnografia sobre os tempos em conflito na Febem, apresentada no fim deste capítulo, desenvolvo a passagem do tempo que é preciso matar, para o tempo vivido intensamente na prática musical.

119 Em alguns pólos, e mesmo na Febem, houve períodos em que era possível levar o instrumento do Guri para casa, ou para a Unidade Educacional, no caso dos internos. Essas iniciativas não foram mantidas na maioria dos pólos, segundo a coordenação, por motivos de preservação dos instrumentos.

120 "A kathakali performer, a ballet dancer, a noh shite each have their genre-specific ways of moving, sounding, and, I would say, being: they are marked people.” (Schechner, 1995: 257).

121 Uso aqui performance no lugar de “playing”, no original de Schechner. Em inglês, play pode ser traduzido por jogo, atuação, execução instrumental etc. $\mathrm{O}$ autor ora fala da atuação teatral, ora de outros tipos de performances, como a musical, por exemplo.

122 Como já apontei anteriormente, as práticas da tranca (trancar os quartos nos quais os internos dormem), do isolamento e dos castigos físicos eram e são ainda comuns na Febem (as notícias mais recentes foram divulgadas a partir de visitas de uma inspetora da ONU no segundo semestre de 2003), em clara desobediência ao Estatuto da Criança e do Adolescente (ECA).

123 Há duas classificações de atos infracionais, traduzidos no vocabulário institucional como "circuito médio" (relativo a furtos e assaltos sem arma, por exemplo) e "circuito grave" (homicídios, estupros, roubos com seqüestro da vítima, roubo qualificado [assalto a mão armada]). Apesar da tentativa de triagem dos jovens de acordo com a idade e infração, a estrutura da Febem, marcada pelo número excessivo de internos, nunca comportou tais separações. Atualmente, após inúmeras mudanças na estrutura física da Febem após as rebeliões de 1999, os jovens do "circuito grave" são, muitas vezes, enviados para unidades como Franco da Rocha, com mais características de presídio que as unidades do Tatuapé. 
124 Em artigo que escrevi com Paula Miraglia (Hikiji \& Miraglia, 2000), analisamos os efeitos da indefinição com relação ao tempo da internação. A frase "peguei tempo indeterminado", pronunciada por qualquer interno questionado sobre a duração de sua internação, revela a total falta de conhecimento da sua condição, do seu processo judicial e de seus direitos. Ela é, entretanto, comum. Isto porque apesar do ECA determinar que a internação deve ser de no mínimo seis meses e no máximo três anos, todos os jovens são internados por “tempo indeterminado". Com isso, o ECA pretende protegêlos de receber uma “pena”, nos moldes da justiça comum, determinando ainda que os processos sejam reavaliados periodicamente pelo juiz, que pode apressar ou não a medida de desinternação. O problema é que como os jovens não possuem clareza sobre essa dinâmica, interpretam o "tempo indeterminado" como a pena em si. Essa interpretação, associada à desinformação, é uma das principais fontes da angústia do jovem.

125 A base para a reflexão acerca da liminaridade na obra de Turner é a análise da estrutura dos ritos de passagem, tal qual pensada por Van Gennep (Gennep, 1960; apud Turner, 1970, 1974, 1974b, 1982). Tais ritos - presentes em todas as sociedades, mas mais evidentes nas de pequena escala - acompanhariam toda mudança de lugar, estado, posição social e idade. Caracterizam-se por uma estrutura na qual distinguem-se três fases. A separação, que marca o desligamento do sujeito ritual, individual ou coletivo, quer de um ponto fixo anterior na estrutura social, quer de um conjunto de condições culturais (um “estado”), ou ambos. O período de transição ou liminar (chamado por Gennep de “margin" ou "limen"), no qual o sujeito ritual atravessa um período e uma área de ambigüidade, um tipo de limbo social, já que tem poucos ou nenhum dos atributos de seu status passado ou futuro. E, por fim, a reagregação ou incorporação, que implica o retorno do sujeito ritual à sua nova posição na sociedade total. A passagem é consumada; ele está de novo em uma situação estável, com direitos e obrigações, sujeito a viver de acordo com normas e éticas.

126 De acordo com o artigo 104 do ECA, "São penalmente inimputáveis os menores de dezoito anos, sujeitos às medidas previstas nesta lei”. Com efeito, ao cometer um ato infracional, o jovem deve ser julgado numa Vara Criminal especial dentro dos Tribunais de Justiça e em seu julgamento devem ser aplicadas as medidas previstas no ECA.

127 Ariés mostrou de forma ímpar a construção cultural da infância e do "sentimento de 
infância” e a progressiva separação entre o universo infantil e o adulto, basicamente inexistente até a Idade Média. Aproximando essa discussão da situação brasileira contemporânea, Adorno (1993: 185) lembra que “o conceito de infância constitui uma construção cultural subjacente ao modo pelo qual diferentes sociedades organizam a reprodução de suas condições materiais e não-materiais de trabalho e de vida. [...] Nas sociedades modernas, a vida infantil aparece como contraposta à adulta, no sentido de que aquela é sede de um sincretismo entre simbolização e realidade. Nesse sentido, o devaneio e o lúdico fariam parte do modo de ser criança”. Mas, o que ocorre na sociedade brasileira é que "não poucas crianças assumem responsabilidades adultas, embora permaneçam imersas na cultura infantil”, devido à necessidade de garantir a reprodução imediata da existência. A essas crianças é geralmente destinada a designação "menor”, que, por sua vez, é, hoje, indissociável, das idéias de "pobreza", "infração” e mesmo "crime”.

128 Quando da realização do vídeo Microfone, senhora, comentado na Abertura da tese, uma preocupação importante foi como evitar a tarja para não identificar os internos. Recurso usado comumente no jornalismo impresso ou televisivo, a tarja estigmatiza o representado, como alguém que cometeu um delito ou como vítima, que não pode ser identificada. Em ambos os casos, é relacionada ao universo da criminalidade.

129 Algumas reflexões sobre o tempo na Febem aqui apresentadas foram originalmente publicadas em artigo da revista Sexta feira - antropologia artes humanidades, escrito juntamente com Paula Miraglia (Hikiji \& Miraglia, 2000).

130 Goffman define as instituições totais como locais que centralizam, em um mesmo espaço e sob a mesma autoridade, a realização de todos os aspectos da vida. Vale a pena seguir sua definição: “Uma disposição básica da sociedade moderna é que o indivíduo tende a dormir, brincar e trabalhar em diferentes lugares, com diferentes co-participantes, sob diferentes autoridades e sem um plano racional geral. O aspecto central das instituições totais pode ser descrito como a ruptura das barreiras que comumente separam essas três esferas da vida. Em primeiro lugar, todos os aspectos da vida são realizados no mesmo local e sob uma única autoridade. Em segundo lugar, cada fase da atividade diária do participante é realizada na companhia imediata de um grupo relativamente grande de outras pessoas, todas elas tratadas da mesma forma e obrigadas a fazer as mesmas coisas em conjunto. Em terceiro lugar, todas as atividades diárias são rigorosa- 
mente estabelecidas em horários, pois uma atividade leva, em tempo predeterminado, à seguinte, e toda a seqüência de atividades é imposta de cima, por um sistema de regras formais explícitas e um grupo de funcionários. Finalmente, as várias atividades obrigatórias são reunidas num plano racional único, supostamente planejado para atender aos objetivos oficiais da instituição”.

131 As descrições do campo de concentração e da cadeia para adultos são de Goffman (1974: 43).

132 O complexo do Tatuapé da Febem, onde realizei a pesquisa, é uma grande área cercada que abriga, no seu interior, as várias unidades onde os internos são alocados. Além das unidades, há espaços como a escola, a biblioteca, campos de futebol, piscina, a casa dos Projetos Especiais (Artes) etc. As unidades do "circuito grave” são as mais fechadas: os muros mais altos, a entrada mais controlada.

133 As aspas reforçam o olhar da mídia para as notícias. Mesmo quando o Guri já contava com mais de 20 pólos em todo o Estado, a imprensa sempre destacou as atividades do pólo Febem, o que levava até à confusão de todos os alunos com “internos da Febem”, que, como já mostrei, causava descontentamento geral.

134 Os motivos da interrupção foram comentados em entrevista com a coordenação do projeto. Segundo Silvana Cardoso, coordenadora técnica do Guri, foram: a reestruturação da Febem - “com a última rebelião, estão descentralizando e pedindo para atendermos nessas novas unidades [as prisões]”, a passagem das aulas para o interior das unidades (“dentro das unidades, é a casa deles. Na casa deles, tem aquele que se interessa pelo estudo e o que não se interessa"), a superlotação e o perfil dos internos ("Como a Febem não atende mais carente, e sim circuito grave, na verdade, não são mais meninos, são homens. Mudou a característica deles: muito mais violentos, rudes.”). Cabe notar que a justificativa da mudança no perfil (de carente para “circuito grave”) é, em parte, equivocada. A Febem Tatuapé manteve até 1999 uma única unidade para menores abandonados, que foi fechada em seguida. O público atingido pelo Guri na Febem sempre foi de menores que haviam cometido algum tipo de infração. A justificativa revela, portanto, o universo de representações da coordenação do projeto, por vezes, mais próximo da imaginação do senso comum que da realidade do grupo que atende. Por outro lado, em 2003, ouvi da coordenação de Projetos Especiais da Febem o mesmo argumento 
da mudança do perfil do jovem interno. A coordenadora não falava, obviamente, em carentes x circuito grave, mas comentava a inserção de um número cada vez maior de jovens nos quadros do crime organizado, em oposição aos pequenos furtos e roubos que caracterizavam as internações anteriores (a referência temporal da entrevistada era o período em que eu realizei a pesquisa na Febem - sobretudo 1999 - e o ano de 2003). $\mathrm{O}$ argumento da coordenação da Febem não diferia, em conteúdo, do da coordenação do Guri: os jovens estariam de fato mais violentos, o que dificultaria o desenvolvimento das atividades especiais, como o Guri, na opinião das mesmas coordenadoras. Infelizmente, tal percepção vem sendo usada também para justificar ações mais violentas, um tratamento em desacordo com o ECA para com o jovem internado e o movimento pela diminuição da idade penal.

135 Cf. matéria publicada no jornal O Estado de S.Paulo, de 26/11/2003.

${ }^{136}$ Turner afirmou o potencial subversivo das atividades liminóides. Ao contrário dos processos liminais (aqui, refere-se aos mitos e ritos, que também chama de gêneros "sérios" da ação simbólica), implicados em visões cíclicas repetitivas do processo social, os gêneros liminóides, embora menos sérios aos olhos da comunidade, têm grande potencial para mudar os modos pelos quais os homens relacionam-se uns com os outros (Turner, 1974b).

\section{CONSIDERAÇÕES FINAIS}

137 O filme acompanha Weyak, um guerreiro, e Pua, um pequeno guardador de porcos, enquanto a sociedade passa por uma série de crises causadas pela guerra. As batalhas e funerais que exibe não foram reconstituídas ou representadas, estavam acontecendo de fato durante as filmagens (cf. Heider, 1995).

138 Renato Sztutman (no prelo) lembra que a Nouvelle Vague - de Godard, François Truffaut, Jacques Rivette, entre outros - muito deve às inovações éticas e estéticas de Rouch, como a abolição do tripé e o registro simultâneo de imagem e som em situação, permitido pelo uso de um magnetofone. Tais criações teriam possibilitado a emergência do cinema-direto, além da ampliação da noção de cinema verdade.

${ }^{139}$ Sobre Jean Rouch, ver Colleyn (1995), Sztutman (1997), Schuler \& Sztutman (1997), 
Rouch (1995 [1974]), entre outros, e o vídeo Jean Rouch, subvertendo fronteiras (Cunha, Marques, Morgado \& Sztutman, 2000).

140 O processo, felizmente, não termina aqui. Junto ao Projeto Temático "Alteridade, expressões culturais do mundo sensível e construções da realidade - Velhas questões, novas inquietações”, começo a desenvolver essas possibilidades dialógicas a partir do vídeo, com alguns jovens pesquisados para a presente pesquisa e com participantes de outros projetos.

141 Sobre o vídeo nas aldeias: Gallois \& Carelli (1993, 1998). Gallois, in Feldman-bianco \& Moreira Leite (1998), Schuler (1998).

142 Nas oficinas de vídeo oferecidas juntamente com Paula Miraglia, em 1999, na Febem Tatuapé (Cf. Abertura).

143 Feld utiliza-se do conceito de Armstrong de "affecting presence" em vez de "arte" ou “representação”, para tratar de manifestações do sensível como pinturas, esculturas, músicas ou fotografias. As “affecting presences” seriam produções que podemos experimentar de modo sensível.

144 Depoimentos de membros da coordenação do Projeto Guri, ao comentarem a recepção do projeto entre os jovens internos na Febem.

145 Isso se dá ao menos em São Paulo, onde foi realizada a pesquisa. No entanto, tal tema merece mais atenção e uma pesquisa nesse sentido traria informações valiosas para a compreensão do universo sócio-musical no país.

146 São conhecidos os casos de músicos e orquestras inteiras que se recusaram a tocar com maestros que trabalharam para o nazismo.

147 E, nesse sentido, corrobora o individualismo, valorizado nas sociedades com escrita. David Howes (1991) nota que, em sociedades sem escrita, a vivência comunitária é privilegiada, diferentemente do que se dá nas sociedades com escrita. Lembra que ouvir é uma atividade que pode ser coletiva (como a audição de uma música ou de um mito), enquanto ler é uma atividade individual. É interessante pensar que mesmo na sociedade urbana brasileira, em famílias de baixa renda, nas quais os pais têm, em geral, poucos anos de escolaridade, a oralidade pode estar mais presente que a escrita. Além disso, é evidente a maior ênfase na vida comunitária em bairros populares.

148 Uma exceção são as aulas pagas de musicalização para crianças pequenas (geralmente 
até os sete, oito anos). A música, nesse caso, atua como agente de sensibilização e sociabilização. Já a criança mais velha e o jovem são mais estimulados a desenvolver habilidades que os diferenciem e individualizem. 


\section{BIBLIOGRAFIA}

ADORNO, Sérgio, LIMA, Renato Sérgio de \& BORDINI, Eliana B. T. O adolescente na criminalidade urbana em São Paulo. Brasília, Ministério da Justiça/Secretaria de Estado dos Direitos Humanos, 1999.

ADORNO, Sérgio. “A experiência precoce da punição”. In MARTINS, José de Souza (org.). Massacre dos inocentes - A criança sem infância no Brasil. São Paulo, Hucitec, 1993.

ALMIRANTE. No tempo de Noel Rosa. Rio de Janeiro, Francisco Alves, 1963.

ARIÈS, Philippe. História social da criança e da família. Rio de Janeiro, Zahar, 1978.

ARISTÓTELES. Poética. São Paulo, Ars Poetica, 1993.

AZEVEDO, Thales de. "Catequese e aculturação". In Schaden, Egon. Leituras de etnologia brasileira. São Paulo, Companhia Editora Nacional, 1976.

BARENBOIM, Daniel \& SAID, Edward. Paralelos e paradoxos. Reflexões sobre música e sociedade. São Paulo, Companhia das Letras, 2003.

BARTHES, Roland. O óbvio e o obtuso. Rio de Janeiro, Nova Fronteira, 1990.

BASAGLIA, Franco. Instituição negada. Rio de Janeiro, Graal, 1985.

BASSO, Ellen B. A musical view of the universe. Filadélfia, University of Pennsylvania Press, 1985.

BASTOS, Rafael José de Menezes. A musicologia Kamayurá. Para uma antropologia da comunicação no Alto-Xingu. Brasília, Fundação Nacional do Índio, 1978.

BENDIX, Reinhard. "The extension of citizenship to the lower classes. In Nationbuilding and citizenship - Studies of our changing social order. Berkeley, University of California Press, 1977.

BENJAMIN, Walter. “A crise do romance. Sobre Alexandersplatz, de Döblin”. In Obras Escolhidas. Magia e técnica, arte e política. São Paulo, Brasiliense, 1996a.

BENJAMIN, Walter. "A doutrina das semelhanças”. In Obras Escolhidas. Magia e técnica, arte e política. São Paulo, Brasiliense, 1996b.

BENJAMIN, Walter. “Experiência e pobreza”. In Obras escolhidas. Magia e técnica, arte 
e política. São Paulo, Brasiliense, 1996c.

BENJAmin, Walter. “O Surrealismo”. In Os Pensadores. São Paulo, Abril Cultural, 1983.

BENJAMIN, Walter. "Pequena história da fotografia”. In Obras Escolhidas. Magia e técnica, arte e política. São Paulo, Brasiliense, 1996d.

BIERRENBACH, Maria Inês. "Instituição fechada e violência: uma visão de dentro". In SADER, Emir. (org.). Fogo no pavilhão - Uma proposta de liberdade para o menor. São Paulo, Brasiliense, 1987.

BLACKING, John. How musical is man?. Seattle and London, University of Washington Press, 1974.

BLACKING, John. Music, culture \& experience. Chicago, University of Chicago Press, 1995.

BORGES PEREIRA, João Baptista. Cor, profissão e mobilidade. O negro e o rádio de São Paulo. São Paulo, Edusp, 2001 [1967].

BRANDÃO, Carlos Rodrigues. Casa de escola. Cultura camponesa e educação rural. Campinas, Papirus, 1983.

BRUHNS \& GUTIERREZ (orgs.). O corpo e o lúdico. Campinas, Editora Autores Associados, 2000.

BRUNI, José Carlos. “Tempo e trabalho intelectual”. In Tempo Social 3 (1-2). São Paulo, USP, 1991.

CAIUBY NOVAES, Sylvia (coord.). Alteridade, expressões culturais do mundo sensível $e$ construções da realidade. Velhas questões, novas inquietações. Projeto Temático apresentado à FAPESP em 2002.

CAIUBY NOVAES, Sylvia (coord.). Imagem em foco nas ciências sociais. Projeto temático apresentado à FAPESP em junho de 1998.

CAIUBY NOVAES, Sylvia. Jogo de espelhos: imagens da representação de si através dos outros. São Paulo, Edusp, 1993.

CALDEIRA, Teresa Pires do Rio. A política dos outros. O cotidiano dos moradores da periferia e o que pensam do poder e dos poderosos. São Paulo, Brasiliense, 1984.

CALDEIRA, Teresa Pires do Rio. Cidade de muros. Crime, segregação e cidadania em São Paulo. São Paulo, Edusp/Editora 34, 2000. 
CANDÉ, Roland de. Convite à música. Lisboa, Martins Fontes, 1986.

CARDOSO, Ruth. "Aventuras de antropólogos em campo ou como escapar das armadilhas do método”. In CARDOSO, Ruth (org.). A aventura antropológica. Rio de Janeiro, Paz e Terra, 1988.

CARNEIRO DA CUNHA, Manuela \& VIVEIROS DE CASTRO, Eduardo. "Vingança e temporalidade: os Tupinambás”. In Anuário Antropológico, 1985/86.

CASTRO, Mary Garcia (coord.) et alli. Cultivando vida, desarmando violências: experiências em educação, cultura, lazer, esporte e cidadania com jovens em situação de pobreza. Brasília, UNESCO, Brasil Telecom, Fundação Kellogg, BID, 2001.

CEDEC. Mapa de Risco daViolência - cidade de São Paulo. Centro de estudos de Cultura Contemporânea - CEDEC, 1996.

CHAVES, Antônio. Comentários ao Estatuto da criança e do adolescente. São Paulo, Editora LTR, 1994.

CLAXTON, William. Jazz. Photos by William Claxton. Taschen Diary, 1998.

COHN, Clarice. A criança indígena: a concepção Xikrin de infância e aprendizado. Dissertação de mestrado. São Paulo, Antropologia, USP, 2000.

COLLEYN, Jean-Paul. "Jean Rouch, 54 anos sem tripé". Entrevista In Cadernos de Antropologia e Imagem, n. 1. Rio de Janeiro, UERJ, 1995.

COLOMBRES, A. Cine, antropologia y colonialismo. Buenos Aires, Ediciones del Sol, 1985.

CONTIER, Arnaldo Daraya. Brasil Novo. Música, nação e modernidade: os anos 20 e 30. Tese de Livre Docência apresentada à FFLCH-USP, São Paulo, 1988.

CRAWFORD, P. \& SIMONSEN, J. Ethnographic film - aesthetics and narrative traditions. Aarhus, Intervention Press, 1992.

CRAWFORD, P. \& TURTON, D. Film as ethnography. Manchester, Manchester University Press, 1992.

DAGGER, Richard. "Rights”. In BALL, FARR \& HANSON (eds.). Political innovation and conceptual change. Cambridge, Cambridge University Press, 1989.

DAMATTA, Roberto. A casa \& a rua. Rio de Janeiro, Guanabara, 1991.

DAWSEY, John Cowart. De que riem os "bóias-frias"? Walter Benjamin e o teatro épico de Brecht em carrocerias de caminhões. São Paulo, FFLCH/USP, 1998. 
DIMENSTEIN, Gilberto. "Aumentar auto-estima é arma contra crime". In Folha de S. Paulo, Caderno Mundo, p. 23, 26 de julho de 1998.

ECA - Estatuto da Criança e do Adolescente. Lei Federal no 8.069, de 13 de julho de 1990. No site www.andi.org.br.

EISENSTEIN, Sergei. A forma do filme. Rio de Janeiro, Jorge Zahar Editor, 1990a.

EISENSTEIN, Sergei. O sentido do filme. Rio de Janeiro, Jorge Zahar Editor, $1990 \mathrm{~b}$.

ELIAS, Norbert. O processo civilizador. Rio de Janeiro, Zahar, 1994.

FELD, Steven. "Ethnomusicology and visual communication". In SHELEMAY, Kay Kaufman (ed.). Ethnomusicology. History, definitions, and scope. Nova Iorque, Garland Publishing, Inc., 1992.

FELD, Steven. "Sound structure as social structure". In Ethnomusicology, 28 (3), 1984.

FELD, Steven. Sound and sentiment. Birds, weeping, poetics, and song In Kaluli expression. Filadélfia, University of Pennsylvania Press, 1982.

FELDMAN, Allen. Formantions of violence - The narrative of the body and political terror In Northern Ireland. Chicago, The University of Chicago Press, 1991.

FERRARI, MARRAS \& SZTUTMAN. "Maria Lúcia Montes - Fragmentos de uma [entrevista[ jamais realizada”. In Sexta Feira - antropologia artes humanidades n.5 [tempo]. São Paulo, Hedra, 2000.

FERREIRA, Rosa Maria Fischer. Meninos de rua. Valores e expectativas de menores marginalizados em São Paulo. São Paulo, Comissão Justiça e Paz de São Paulo, 1979.

FLAHERTY, Robert. "How I filmed Nanook of the North". In GEDULD (ed.). Film makers on film making. Penguin, s/d.

FOUCAULT, Michel. Vigiar e punir. História da violência nas prisões. Rio de Janeiro, Vozes, 1988.

GALINDO, João Mauricio. Instrumentos de arco e ensino coletivo: a construção de um método. Dissertação de mestrado no curso de Artes, área de Musicologia, da Escola de Comunicações e Artes da Universidade de São Paulo. São Paulo, USP, 2000.

GALLOIS, Dominique \& CARELLI, Vincent. "A experiência waiãpi do vídeo”. In Cadernos de Campo, v.2. São Paulo, USP, 1993.

GALLOIS, Dominique \& CARELLI, Vincent. “'Índios eletrônicos’: a rede indígena 
de comunicação". In Sexta Feira - antropologia artes humanidades, v.2. São Paulo, Pletora, 1998.

GALLOIS, Dominique. “Antropólogos na mídia: comentários acerca de algumas experiências de comunicação intercultural”. In FELDMANBIANCO, Bela e MOREIRA LEITE, Miriam (Orgs). Desafios da imagem. Campinas, Papirus, 1998.

GEERTZ, Clifford. A Interpretação das culturas. Rio de Janeiro, Guanabara, 1989.

GEERTZ, Clifford. Local Knowledge. Nova Iorque, Basic Books, 1983.

GEERTZ, Clifford. Nova luz sobre a antropologia. Rio de Janeiro, Jorge Zahar Ed., 2001.

GEERTZ, Clifford. Works and Lives. The Anthropologist as Author. California, Stanford University Press, 1994.

GÉLIS, Jacques. “A individualização da criança”, in ARIĖS, P. \& CHARTIER,

R. História da vida privada 3. Da Renascença ao século das luzes. São Paulo, Companhia das Letras, 1991.

GELL, Alfred. Art and agency: an anthropological theory. Oxford, Oxford University Press, 1998.

GELL, Alfred. The anthropology of time. Cultural constructions of temporal maps and images. Providence, Oxford: Berg Publishers, 1992.

GIRARD, René. A violência e o sagrado. Rio de Janeiro, Paz e Terra, 1990.

GOFFMAN, Erving. Manicômios, prisões e conventos. São Paulo, Perspectiva, 1974.

GOIFFMAN, KIKO. Valetes em slow motion. Campinas, Editora da Unicamp, 1998.

GREGORI, Maria Filomena. Meninos nas ruas: a experiência da viração. Tese de doutoramento, Antropologia-USP. São Paulo, USP, 1997.

GUASCO, Pedro Paulo M. Num país chamado periferia: identidade e representação da realidade entre os rappers de São Paulo. Dissertação de mestrado apresentada ao PPGAS-USP, 2001.

GUERREIRO, Goli. A trama dos tambores. Samba-reggae: invenção rítmica no meio 
musical de Salvador Bahia - Brasil. São Paulo, USP, 1999.

HEIDER, Karl. "Uma história do filme etnográfico". In Cadernos de antropologia e imagem 1 - antropologia e cinema: primeiros contatos. Rio de Janeiro, UERJ, 1995.

HENLEY, Paul. "Cinematografia e pesquisa etnográfica”. In Cadernos de Antropologia e Imagem, v.9. Rio de Janeiro, UERJ, 1999.

HIKIJI, Rose Satiko \& MIRAGLIA, Paula. “'Peguei tempo indeterminado’: vigilância, violência e revolta entre os muros da Febem”, in Sexta Feira - antropologia artes humanidades, n. 5. São Paulo, Hedra/Pletora, outubro de 2000.

HIKIJI, Rose Satiko \& MIRAGLIA, Paula. "Imagens em construção. O uso do vídeo como forma de comunicação com o interno da Febem”. In Cadernos de antropologia e imagem, n.13, v.1. Rio de Janeiro, NAI/UERJ, 2003.

HIKIJI, Rose Satiko. "Antropólogos vão ao cinema - observações sobre a constituição do filme como campo". In Cadernos de Campo v.7. São Paulo, USP, p.91 - 113, 1998.

HIKIJI, Rose Satiko. Imagem-violência. Mimesis e reflexividade em alguns filmes recentes. Dissertação de mestrado apresentada ao Programa de Pós-graduação em antropologia da Universidade de São Paulo (PPGAS-USP). São Paulo, 1999.

HOLSTON, James \& APPADURAI, Arjun. "Cities and citizenship”. In Public culture, $8(2): 187-204$.

HOOD, Mantle. "Ethnomusicology". In SHELEMAY, Kay Kaufman (ed.). Ethnomusicology. History, definitions, and scope. Nova Iorque, Garland Publishing, Inc., 1992.

HOWES, David. A sourcebook In the anthropology of the senses. Toronto, University of Toronto Press, 1991.

HUIZINGA, Johan. Homo ludens. O jogo como elemento da cultura. São Paulo, Perspectiva, 2000.

JAMESON, Fredric. As marcas do visível. Rio de Janeiro, Graal, 1995.

JORDAN, Pierre. "Primeiros contatos, primeiros olhares". In Cadernos de antropologia e imagem 1 - antropologia e cinema: primeiros contatos. Rio de Janeiro, UERJ, 1995.

JOURDAIN, Robert. Música, cérebro e êxtase. Como a música captura nossa imaginação. Rio de Janeiro, Editora Objetiva, 1998. 
KANT DE LIMA, ROBERTO. “A administração dos conflitos no Brasil: a lógica da punição" In Cidadania e violência. Rio de Janeiro, Editora UFRJ e Editora FGV, 1996.

KOMINSKY, EthelVolfzon. A infância assistida. Tese de doutoramento, Departamento de Sociologia, FFLCH/USP, 1992.

KOSMINSKY, Ethel Volfzon. "Internados - Os filhos do Estado padrasto". In MARTINS, José de Souza (org.). Massacre dos inocentes - A criança sem infầncia no Brasil. São Paulo, Hucitec, 1993.

LEHMANN, Bernard. «L'envers de l'harmonie”. In Actes de la recherche en sciences sociales, 110. Paris, Éditions du Seuil, dez/ 1995.

LÉVI-STRAUSS, Claude. Antropologia estrutural. Rio de Janeiro, Tempo Brasileiro, s/data.

LÉVI-STRAUSS, Claude. O cru e o cozido. São Paulo, Brasiliense, 1991.

LÉVI-STRAUSS, Claude. Olhar escutar ler. São Paulo, Companhia das Letras, 1997.

LOIZOS, P. Innovation in ethnographic film - from innocence to self-consciousness, 1955-85. Manchester, Manchester University Press, 1993.

LONDOÑO, Fernando Torres. "A origem do conceito menor”. In PRIORE, Mary Del. História da criança no Brasil. São Paulo, Contexto, $4^{a}$ edição, 1996.

MACDOUGALL, David. “Mas afinal, existe realmente uma antropologia visual?”. In Catálogo da 2a . Mostra Internacional do Filme Etnográfico.

MAGNANI, José Guilherme Cantor. "Da periferia ao centro: pedaços \& trajetos”. In Revista de Antropologia. São Paulo, USP, v. 35, p. 191-203, 1992.

MAGNANI, José Guilherme Cantor. "Lazer na cidade”. In www.aguaforte.com/ antropologia/magnani2.html, in 27/2/2003.

MAGNANI, José Guilherme Cantor. „Lazer, um campo interdisciplinar de pesquisa“, In BRUHNS \& GUTIERREZ (orgs.). O corpo e o lúdico. Campinas, Editora Autores Associados, 2000.

MAGNANI, José Guilherme Cantor. "Quando o campo é a cidade: fazendo antropologia na metrópole”. In MAGNANI, J.G.C. \& TORRES, L.L. (org.). Na metrópole. Textos de antropologia urbana. São Paulo, Edusp, Fapesp, 1996.

MAGNANI, José Guilherme Cantor. Festa no pedaço. Cultura popular e lazer na cidade. 
São Paulo, Brasiliense, 1984.

MAMDANI, Mahmood. When victims become killers: colonialism, nativism and genocide In Rwanda. Princeton, Princeton University Press, 2001.

MANN, Thomas. A montanha mágica. Rio de Janeiro, Nova Fronteira, 1980.

MARCUS, G.E. \& CUSHMAN, D. "Ethnographies as texts". In Annual Reviews Anthropology, n.11,1982.

MARCUS, George E. "The modernist sensibility in recent ethnographic writing and the cinematic metaphor of montage". In TAYLOR, Lucien (ed.). Visualizing theory. Nova Iorque, Routledge, 1994.

MARTINS, José de Souza. "Introdução" e "Regimar e seus amigos - A criança na luta pela terra e pela vida”. In MARTINS, José de Souza (org.). Massacre dos inocentes - A criança sem infầncia no Brasil. São Paulo, Hucitec, 1993.

MAUSS, Marcel. “As técnicas corporais”. In Sociologia e Antropologia vol. 2. São Paulo, E.P.U., 1974.MARTINS, José de Souza (org.). Massacre dos inocentes - A criança sem infância no Brasil. São Paulo, Hucitec, 1993.

MENEZES, Paulo. "Problematizando a 'representação': fundamentos sociológicos da relação entre cinema, real e sociedade”. In Sociedade Brasileira de Estudos de Cinema. Porto Alegre, Sulina, 2001.

MERRIAM, Alan P. Ethnomusicology. "Discussion and definiton of the field". In SHELEMAY, Kay Kaufman (ed.). Ethnomusicology. History, definitions, and scope. Nova Iorque, Garland Publishing, Inc., 1992.

MERRIAM, Alan P. The Anthropology of music. Evanston, Illinois, Northwestern University Press, 1997.

MIRAGLIA, Paula. Juventude, criminalidade e pobreza. Uma aproximação etnográfica. Projeto de doutorado apresentado ao Programa de pós-graduação em antropologia social da Universidade de São Paulo (PPGAS-USP) em 2002 (mimeo).

MIRAGLIA, Paula. Rituais da violência. A Febem como espaço do medo em São Paulo. São Paulo, PPGAS-USP, Dissertação de Mestrado, 2001.

MIRANDA, Dilmar Santos de. Tempo da festa x tempo do trabalho. Transgressão e carnavalização na belle époque tropical. Tese de doutoramento em sociologia. São Paulo, USP, 2001. 
MONTE-MÓR, Patrícia. "Descrevendo culturas: etnografia e cinema no Brasil”. In Cadernos de antropologia e imagem 1 - antropologia e cinema: primeiros contatos. Rio de Janeiro, UERJ, 1995.

MONTES, Maria Lúcia. "Violência, cultura popular e organizações comunitárias" In Cidadania e violência. Rio de Janeiro, Editora UFRJ e Editora FGV, 1996.

MORIN, Edgar. “A alma do cinema”. In XAVIER, Ismail. A experiência do cinema. Rio de Janeiro, Graal, 1991.

NETTL, Bruno. The study of ethnomusicology. Urbana, University of Illinois Press, 1983.

NICHOLS, Bill. "The Voice of Documentary", In Rosenthal, Alan (Ed.): New Challenges for Documentary. Berkley, University of California Press, 1988.

NICHOLS, Bill. Ideology and the image. Bloomington, Indiana University Press, 1981.

NICHOLS, Bill. Representing reality. Bloomington e Indianapolis, Indiana University Press, 1991.

NOVAES, Adauto (Org). O olhar. São Paulo, Brasiliense, 1990.

OLIVEIRA PINTO, Tiago de. "Som e música: questões de uma antropologia sonora”. In Revista de Antropologia. São Paulo, USP, v. 44, n. 1, 2001.

OLIVEIRA, Enaldo. O ensino coletivo dos instrumentos de corda: reflexão e prática. Dissertação de Mestrado, ECA-USP, 1998.

OVERING, Joanna. "A estética da produção: o senso de comunidade entre os Cubeo e os Piaroa”. In Revista de Antropologia. São Paulo, USP, n. 34, 1991.

PEIXOTO, Clarice Ehlers. "Caleidoscópio de imagens: o uso do vídeo e a sua contribuição à análise das relações sociais”. In FELDMAN-BIANCO, Bela e MOREIRA LEITE, Miriam (Orgs). Desafios da imagem. Campinas, Papirus, 1998.

PEREIRA, Angela Maria N. M. A sociedade das crianças A'UWE-XAVANTE. Por uma antropologia da criança. Dissertação de mestrado. São Paulo, Antropologia, USP, 1997.

PIAGET, Jean. A linguagem e o pensamento da criança. São Paulo, Martins Fontes, 1999.

PIAULT, Marc-Henri. Anthropologie et cinema. Paris, Nathan, 2000. 
PIAULT, Marc-Henri. “A antropologia e a 'passagem à imagem”". In Cadernos de antropologia e imagem 1 - antropologia e cinema: primeiros contatos. Rio de Janeiro, UERJ, 1995.

PIAULT, Marc-Henri. “Antropologia e cinema”. In Catálogo da 2a. Mostra Internacional do Filme Etnográfico.

ROUCH, Jean. “The camera and man”. In HOCKINGS, Paul (Ed.): Principles of visual anthropology. Nova Iorque, Mouton, 1995 [1974].

ROUGET, Gilbert. Music and trance. A theory of the relations between music and possession. Chicago, The University of Chicago Press, 1985.

SACKS, Oliver. Vendo vozes. Uma viagem ao mundo dos surdos. São Paulo, Companhia das Letras, 1998.

SADER, Emir. (org.). Fogo no pavilhão - Uma proposta de liberdade para o menor. São Paulo, Brasiliense, 1987.

SAMAIN, Etienne: "Ver” e “dizer” na tradição etnográfica: Bronislaw Malinowski e a fotografia. In Horizontes Antropológicos, UFRRS, n.2, 1995.

SCHECHNER, Richard. Between theater and anthropology. Filadélfia, University of Pennsylvania Press, 1985.

SCHECHNER, Richard. Performance theory. Nova Iorque e Londres, Routledge, 1988.

SCHECHNER, Richard. The future of ritual. Writings on culture and performance. Londres e Nova Iorque, Routledge, 1995.

SCHULER, Evelyn \& SZTUTMAN, Renato. "A louca maestria de Jean Rouch" [entrevista]. In Sexta Feira - antropologia artes humanidades, v. 1. São Paulo, Pletora, 1997.

SCHULER, Evelyn. "Pelos olhos de Kasiripiña: revisitando a Experiência Waiãpi do 'Vídeo nas aldeias'”. In Sexta Feira - antropologia artes humanidades, v.2. São Paulo, Pletora, 1998.

SCHWARCZ, Lilia Moritz. "Falando do tempo". In Sexta Feira - antropologia artes humanidades n. 5 [tempo]. São Paulo, Hedra, 2000.

SCHWARTZMAN, S., BOMENY, H. M. B. \& COSTA, V. M. R.. Tempos de Capanema. São Paulo, FGV e Paz eTerra, 2000 [1984]. In http: / / www.schwartzman.org.br/ 
simon/capanema/capit3.htm.

Secretaria de Cultura do Governo de São Paulo. Projeto Guri: 1995-2002. São Paulo, Secretaria de Cultura do Governo de São Paulo, 2002.

SEEGER, Anthony. "Ethnography of music". In MYERS, Helen. Ethnomusicology. An introduction. Londres, The MacMillan Press, 1992.

SEEGER, Anthony. Nature and society In central Brazil. The Suya indians of Mato Grosso. Cambridge, Harvard University Press, 1981.

SEEGER, Anthony. Os índios e nós. Estudos sobre sociedades tribais brasileiras. Rio de Janeiro, Editora Campus, 1980.

SEEGER, Anthony. Why Suyá sing. A musical anthropology of an Amazonian people. Cambrige, Cambridge University Press, 1987.

SHELEMAY, Kay Kaufman (ed.). Ethnomusicology. History, definitions, and scope. Nova Iorque, Garland Publishing, Inc., 1992.

SILVA, Franklin Leopoldo. “Tempo: realidade e símbolo”. In SSexta Feira - antropologia artes humanidades n. 5 [tempo]. São Paulo, Hedra, 2000.

SILVA, Marcio. "Perspectivas do tempo". In Sexta Feira - antropologia artes humanidades n. 5 [tempo]. São Paulo, Hedra, 2000.

SOARES, Luiz Eduardo. "A Segurança Pública como Questão das Esquerdas". Síntese da apresentação no Fórum Social Mundial, em 29 de janeiro, 2001.

SOARES, Luiz Eduardo. Violência e política no Rio de Janeiro. Rio de Janeiro, Editora Relume-Dumará/ISER, 1996.

SORLIN, Pierre. Sociologia del cine. México, Fondo de Cultura Económica, 1985.

SPOSATI, Aldaíza (coord.). Mapa da Exclusão/Inclusão Social da Cidade de São Paulo. São Paulo, Educ, 1996.

SPOSITO, Marilia Pontes. "A sociabilidade juvenil e a rua: novos conflitos e ação coletiva na cidade”. In Tempo social v. 5 (1-2). São Paulo, USP, 1994.

SQUEFF, Enio \& WISNIK, José Miguel. Música. São Paulo, Brasiliense, 1982.

STAM, Robert. Reflexivity In film and literature. From Don Quixote to Jean-Luc Godard. Nova Iorque, Columbia University Press, 1992.

STOKES, Martin. "Introduction: Ethnicity, identity and music". In STOKES, Martin (ed.). Ethnicity, identity and music. The musical construction of place. Oxford, Berg 
Publishers, 1994.

SZTUTMAN, Renato. "Jean Rouch e o cinema como subversão de fronteiras". In Sexta Feira - antropologia artes humanidades, v.1. São Paulo, Pletora, 1997.

SZTUTMAN, Renato. "Jean Rouch. Um antropólogo-cineasta'. In Escrituras da Imagem. São Paulo, Edusp, no prelo.

TAUSSIG, Michael. Mimesis and alterity. Nova Iorque, Routledge, 1993a.

TAUSSIG, Michael. Xamanismo, colonialismo e o homem selvagem. São Paulo, Paz e Terra, 1993.

TAYLOR, Lucien (Ed). Visualizing Theory. Nova Iorque e Londres, Routledge, 1994.

TELLES, Vera da Silva. A cidadania inexistente: incivilidade e pobreza. Um estudo sobre trabalho e família na Grande São Paulo. Tese de doutorado. Departamento de Sociologia, USP, 1992.

TITON, JeffTodd (org.). Worlds of music. An introduction to the music of the world's people. Nova Iorque, Shirmer, 1992.

TODOROV, Tzvetan. A conquista da América: a questão do outro. São Paulo, Martins Fontes, 1988.

TURNER, Victor. "Betwixt and between: the liminal period in rites de passage". In The forest of symbols. Ithaca, Cornell University Press, 1970.

TURNER, Victor. "Dewey, Dilthey, and Drama: An essay in the anthropology of experience". In TURNER \& BRUNER (Eds.). The anthropology of experience. Urbana e Chicago, University of Illinois Press, 1986.

TURNER, Victor. Dramas, fields and metaphors. Symbolic action In human society. Ithaca e Londres, Cornell University Press, 1974b.

TURNER, Victor. From ritual to theatre. The human seriousness of play. Nova Iorque, PAJ Publications, 1982.

TURNER, Victor. O processo ritual. Estrutura e antiestrutura. Petrópolis, Vozes, 1974.

TURNER, Victor. The anthropology of performance. Nova Iorque, PAJ Publications, 1987.

VAN VELSEN, J. "The extended-case method and situational analysis". In EPSTEIN (ed.). The craft of social anthropology. Londres, Tavistock Publicatiohns, 1967. 
VARELLA, BERTAZZO \& BERENSTEIN. Maré, vida na favela. Rio de Janeiro, Casa da Palavra, 2002.

VELHO, Gilberto. "Violência, reciprocidade e desigualdade: uma perspectiva antropológica” In Cidadania e violência. Rio de Janeiro, Editora UFRJ e Editora FGV, 1996.

WAICHMAN, Pablo. Tempo livre e recreação: um desafio pedagógico. Campinas, Papirus, 2001.

WAISELFISZ, Jacobo. Mapa da Violência III - Os Jovens do Brasil. Brasília, Unesco, 2002.

WALZER, Michael. "Citizenship". In BALL, FARR \& HANSON (eds.). Political innovation and conceptual change. Cambridge, Cambridge University Press, 1989.

WEBER, Max. Os fundamentos racionais e sociológicos da música. São Paulo, Edusp, 1995.

WISNIK, José Miguel. “Algumas questões de música e política no Brasil”. In BOSI, Alfredo. Cultura brasileira. Temas e situações. São Paulo, Ática, 1987.

WISNIK, José Miguel. O som e o sentido. Uma outra história das músicas. São Paulo, Companhia das Letras, 1999.

ZALUAR, Alba. "Pra não dizer que não falei de samba: os enigmas da violência no Brasil”. In SCHWARCZ, Lilia Moritz (org.). História da vida privada no Brasil: contrastes da intimidade contemporânea, v. 4. São Paulo, Companhia das Letras, 1998.

ZALUAR, Alba. "Teoria e prática do trabalho de campo: alguns problemas". In CARDOSO, Ruth (org.). A aventura antropológica. Rio de Janeiro, Paz e Terra, 1988.

ZALUAR, Alba. Cidadãos não vão ao Paraíso. Campinas, Edunicamp, 1994.

ZALUAR, Alba. Condomínio do diabo. Rio de Janeiro, Editora UFRJ, 1994b. 


\section{FILMOGRAFIA CITADA}

BASTOS, Iracema, SCHULLER, Evelyn \& WAINER, Júlio. As pedras no meio do caminho. Brasil, 1996.

CUNHA, MARQUES, MORGADO \& SZTUTMAN. Jean Rouch, subvertendo fronteiras. Brasil, LISA, 2000.

FELLINI, Federico. Prova d'Orchestra (Ensaio de orquestra). Itália, 1978.

GARDNER, Robert. Dead Birds. EUA, 1963.

GOLDEMBERG, Sérgio. Funk Rio. Brasil, 1994.

SALLES, João Moreira (coord.). Meninos eu vi? Brasil, 1992.

WELLES, Orson. Citizen Kane (Cidadão Kane). EUA, 1941. 


\section{VÍDEOS QUE INTEGRAM A TESE - FICHA TÉCNICA}

\section{Microfone, senhora \\ NTSC, cor, 16', 2003}

Sinopse: Jovens internos na Febem Tatuapé participam da gravação de uma música para o CD de um grupo de rap em São Paulo. Durante o registro do evento, apropriam-se do microfone e, ora assumindo o papel de repórter ou entrevistado, ora fazendo música, protagonizam o vídeo, narrando desde a situação de internação até seus sonhos e expectativas. O vídeo conta ainda com imagens registradas durante oficinas de vídeo realizadas pela autora. Tanto a gravação como as oficinas aconteceram em 1999, ano das mais violentas rebeliões da história da Febem.

Concepção, roteiro, imagens e inserções musicais: Rose Satiko Hikiji Edição: Gianni Puzzo e Rose Satiko Hikiji

Realização: Laboratório de Imagem e Som em Antropologia da Universidade de São Paulo (LISA - USP)

Apoio: Fapesp 
Prelúdio

NTSC, COR, 13', 2003

Sinopse: Jovens estudantes de música falam dos sentidos do aprendizado em suas vidas. A trilha sonora são os ensaios e apresentações do Projeto Guri, iniciativa da Secretaria de Cultura do Estado de São Paulo de ensino musical para crianças e jovens de famílias de baixa renda.

Pesquisa, roteiro, imagens, inserções musicais e edição: Rose Satiko Hikiji Realização: Laboratório de Imagem e Som em Antropologia da Universidade de São Paulo (LISA - USP)

Apoio: Fapesp 
projeto gráfico Florencia Ferrari

capa e contracapa Carmen Novo

imagens dos vídeos Prelúdio e Microfone, senhora

satiko@usp.br 